UNIVERSIDADE DE SÃO PAULO

FACULDADE DE FILOSOFIA, LETRAS E

CIÊNCIAS HUMANAS

DEPARTAMENTO DE LETRAS CLÁSSICAS E VERNÁCULAS

RENATA PALUMBO

\title{
REFERENCIAÇÃO, METÁFORA E ARGUMENTAÇÃO NO DISCURSO PRESIDENCIAL
}

Versão corrigida 
RENATA PALUMBO ${ }^{1}$

\title{
REFERENCIAÇÃO, METÁFORA E ARGUMENTAÇÃO NO DISCURSO PRESIDENCIAL
}

\author{
Versão corrigida
}

Tese apresentada ao Programa de Pós-Graduação em Filologia e Língua Portuguesa, do Departamento de Letras Clássicas e Vernáculas, da Faculdade de Filosofia, Letras e Ciências Humanas da Universidade de São Paulo, para obtenção de título de Doutora em Letras.

Área de concentração: Língua Portuguesa Orientadora: Profa. Dra. Zilda Gaspar Oliveira de Aquino

São Paulo

2013

${ }^{1}$ rpalumbo_07@ig.com.br 


\section{FOLHA DE APROVAÇÃO}

Renata Palumbo

Referenciação, metáfora e argumentação no discurso presidencial

Tese apresentada ao Programa de Pós-Graduação em Filologia e Língua Portuguesa, do Departamento de Letras Clássicas e Vernáculas, da Faculdade de Filosofia, Letras e Ciências Humanas da Universidade de São Paulo, para obtenção de título de Doutora em Letras.

Área de concentração: Língua Portuguesa Orientadora: Profa. Dra. Zilda Gaspar Oliveira de Aquino

Aprovado em:

Banca Examinadora

Profa. Dra.:

Instituição: Assinatura:

Profa. Dra.:

Instituição: Assinatura:

Profa. Dra.:

Instituição: Assinatura:

Prof. Dr.:

Instituição: Assinatura: 
A minha mãe (in memoriam) e a meu pai, por dedicarem a mim boa parte de suas vidas.

A minha amiga Tânia Aparecida Scholz (in memoriam). 


\section{AGRADECIMENTOS}

À Professora e Orientadora Dra. Zilda Gaspar Oliveira de Aquino, pela orientação e pela dedicação. Seu incentivo e apoio, nos momentos mais difíceis, ajudaram-me a chegar até aqui.

Às Professoras Dras. Anna Maria Grammatico Carmagnani e Edwiges Maria Morato, pelas sugestões e pela presença durante o exame de qualificação.

A todos meus professores, por terem cruzado meu caminho, e aos autores, cujos trabalhos eu pude conhecer. Devo a todos eles a possibilidade de realizar esta pesquisa.

A meus pais, Angelina e Donato, e à minha família, pela minha vida e pela dedicação.

Ao Filipe, pelo apoio e pela tradução do resumo desta pesquisa.

Ao Professor e amigo Dr. Paulo Roberto Gonçalves Segundo pelo incentivo e pelos momentos de reflexão.

Aos meus queridos amigos, Iramildes Santos, Cleide Rizerio, Gislaine Amâncio, Eliete Farneda pelos momentos especiais nos quais pudemos aprender, crescer, rir e chorar.

A Deus, por tudo isso. 
[...] a indeterminação da linguagem é uma estratégia de sedução do ouvinte e do leitor para que faça uma opção. Portanto, a indeterminação é a forma que a semiose linguística adota para operar. E a metáfora é um bom exemplo desse tipo de sedução que reporta ao sistema cultural do meio em que ela surge. 


\section{RESUMO}

PALUMBO, R. (2013). Referenciação, metáfora e argumentação no discurso presidencial. 272f. Tese (Doutorado) - Faculdade de Filosofia, Letras e Ciências Humanas, Universidade de São Paulo, São Paulo.

Nesta pesquisa, nosso propósito consistiu em examinar o papel retórico e referenciador da metáfora e em observar como se constituem e se articulam os processos referenciais promovidos pela associação de domínios díspares nas várias etapas dos discursos presidenciais, dirigidos a líderes políticos mundiais especificamente. Para alcançar esse propósito, propusemo-nos aos seguintes passos de investigação, a partir do tratamento qualitativo dos dados: examinamos as metáforas centrais selecionadas e detectamos o momento em que elas apareceram nos pronunciamentos; observamos as redes referenciais relacionadas a essas metáforas; analisamos a função argumentativa da articulação dessas redes metafóricas, na organização discursiva, levando em conta as condições específicas de produção de cada discurso. Nosso corpus constitui-se de dez discursos do ex-presidente da República Federativa do Brasil Luis Inácio Lula da Silva, proferidos: em Davos (2003 e 2005), na Assembleia Geral das Organizações das Nações Unidas, em Nova Iorque (2004), na China (2004), em Portugal (2003 e 2005), na Índia (2004), no Quênia (2010) e na $39^{\circ}$ Reunião de Cúpula do Mersocul, na Argentina (2010). As análises permitiram detectar a existência de metáforas centrais inter-relacionadas e articuladas à argumentação dos discursos. Depreendemos ter havido muitas ocorrências de redes referenciais específicas dessas metáforas, que foram, principalmente, estruturadas pela lógica dos contêineres. Tais resultados levaram-nos a entender que a metáfora conceptual é tanto recurso de referenciação, que pode ser selecionado estrategicamente para fins argumentativos, quanto elemento estruturado e estruturante dos processos referenciais. Nosso trabalho adotou como referencial teórico: i) estudos sobre a referenciação, a partir de Mondada e Dubois (2003), Apothéloz (2003), Marcuschi e Koch (1998), ii) reflexões em torno da argumentação, em que se destacam os trabalhos de Perelman e Olbrechts-Tyteca (2002 [1958]) e Aquino (1997); iii) investigações sobre a metáfora conceptual, realizadas por Lakoff e Johnson (1980, 2003), Kovecses, (2005), e a respeito do discurso político, a partir de Charteris-Black (2011), Chilton (2004).

Palavras-chave: Referenciação. Argumentação. Metáfora conceptual. Discurso Presidencial. 


\begin{abstract}
PALUMBO, R. (2013). Referentiation, metaphor and argumentation in presidential speech. 272f. Doctoral thesis - Faculty of Philosophy, Letters and Human Sciences, University of São Paulo, São Paulo.
\end{abstract}

The aim of this research was to examine the rhetorical and referential role of metaphors, and to analyze the constitution of the referential processes promoted by the association of different domains in the various stages of presidential speeches given to world political leaders. In order to achieve such a goal, the following research steps were carried out, subsequent to the qualitative analysis of the data: selected central metaphors were examined and the moment when they occurred in the speeches were detected; the referential networks related to those metaphors were observed; the argumentative role of the articulation of those metaphorical networks in the discursive organization were observed, taking into account the production conditions that are specific to each speech. The corpus is formed by ten speeches by the former president of the Federative Republic of Brazil, Luis Inácio Lula da Silva, which were given in Davos (2003 and 2005), at the General Assembly of the United Nations Organization, in New York (2004), in China (2004), in Portugal (2003 and 2005), in India (2004), in Kenya (2010) and at the $39^{\text {th }}$ Mercosul Summit, in Argentina (2010). The analyses have allowed the detection of central metaphors inter-related and articulated to the argumentation of the speeches. Specific referential networks of those metaphors have been noticed to be pervasive and structured according to the container logic. These results suggest that conceptual metaphors are both a referential resource, which might be used for argumentative purposes, and an element that structures and is structured by the referential processes. This work has as its theoretical reference: i) the studies on referentiation by Mondada and Dubois (2003), Apothéloz (2003), Marcuschi and Koch (1998); ii) reflections on argumentation by Perelmand and Olbrechts-Tyteca (2002 [1958]), and Aquino (1997); iii) research on conceptual metaphors carried out by Lakoff and Johnson (1980, 2003), Kovecses, (2005), and on political discourse, by Charteris-Black (2011), Chilton (2004).

Key-words: Referentiation. Argumentation. Conceptual Metaphor. Presidential Speech. 


\section{LISTA DE ILUSTRAÇÕES}

Figura 01. Interface discursivo-sociocognitiva do processo de construção de sentido ............79

Figura 02. Esquema da argumentação política de Chateris-Black ..................................... 132

Figura 03. Esquema do processo referencial e metafórico na organização discursiva............176

Figura 04. Ex-presidente da República Lula na abertura da 64a Assembleia Geral da ONU (Organização das Nações Unidas) em 2009 ..................................................................... 178

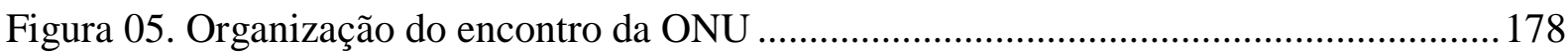

Figura 06. Davos, 2003: esquema referencial-argumentativo ..........................................244

Figura 07. Davos, 2003: organização de categorias conforme a lógica dos contêineres .......245

Figura 08. ONU, 2004: organização de categorias conforme a lógica dos contêineres .........246

Figura 09. Davos, 2005: esquema argumentativo-referencial 1 .......................................2. 248

Figura 10. Davos, 2005: esquema argumentativo-referencial 2 …...................................249

Figura 11. ONU, 2004: referenciação, metáfora e ativação de valor comum ........................251 


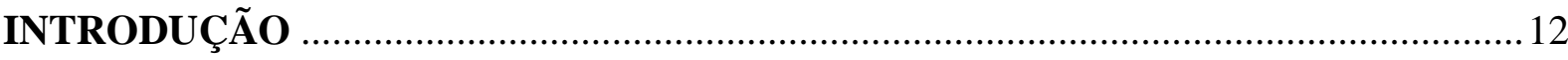

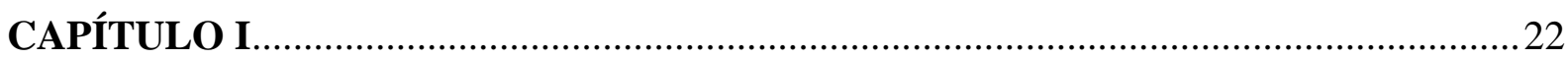

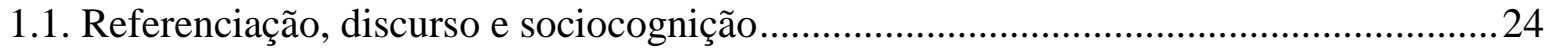

1.2. Abordagem discursiva, cognitiva e interacional da metáfora e sua função referencial. 28

1.2.1. Metáfora conceptual na construção sociocognitiva e discursiva de referências .........35

1.3. Categorias discursivo-sociocognitivas: organizar e dar sentido ao mundo ...................46

1.3.1. Modelos cognitivos de situações interacionais e práticas discursivas ....................54

1.3.1.1. Relação entre modelos cognitivos de eventos sociais, processos referenciais e

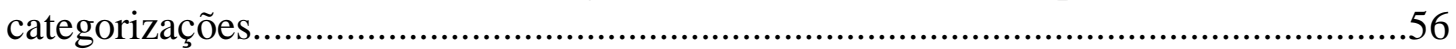

1.3.2. Categorização e recategorização metafórica ...........................................................59

1.3.2.1. Processos de categorização metafórica: inter-relação funcional entre discurso,

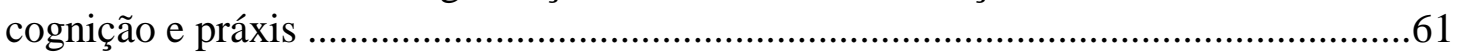

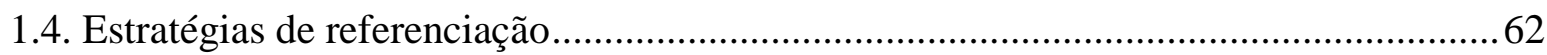

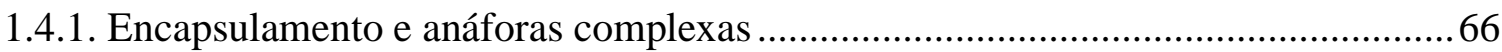

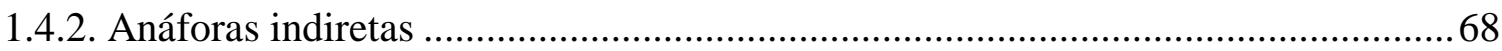

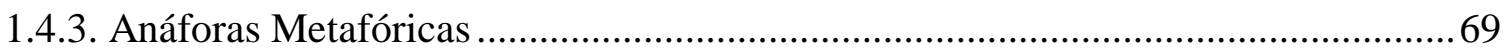

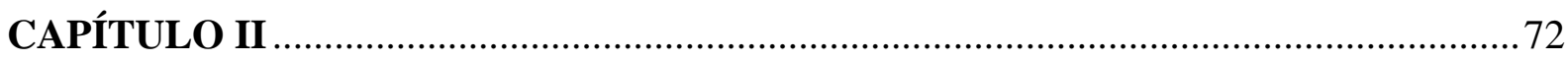

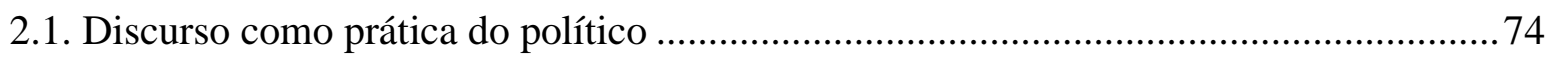

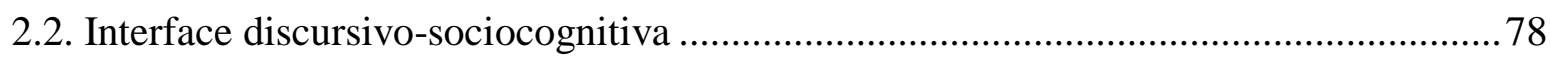

2.3. Discurso presidencial: práticas discursivas e relações de força na política interna e na

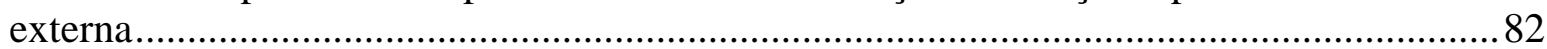

2.3.1. Discurso presidencial no domínio da política interna ........................................... 84

2.3.2. Discurso presidencial no domínio da política externa ......................................... 88

2.4. Estratégia política global do governo Lula e discurso presidencial da mudança ..........94

2.5. Dimensão da política externa do governo Lula ........................................................ 103

2.5.1. Prática discursiva voltada ao multilateralismo e às parcerias bilaterais................ 103

2.6. Ideologias de grupo e discurso presidencial em seu viés internacional ......................111

2.6.1. Posicionamento ideológico no discurso de Lula ................................................. 119

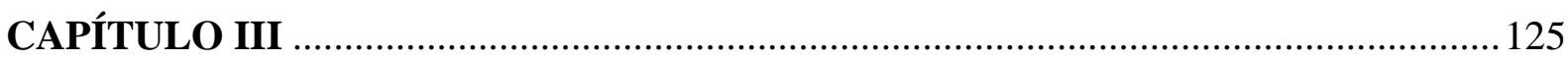

3.1. Função da metáfora nas finalidades argumentativas: compreensão do discurso e

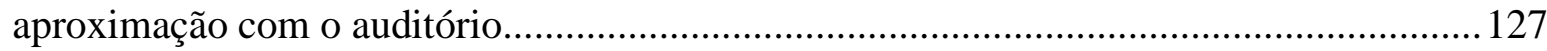

3.2. Potencial da metáfora no dinamismo da argumentação.............................................. 130

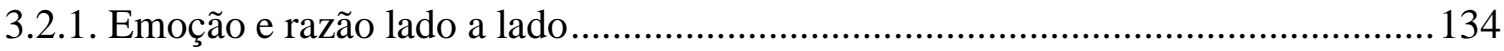

3.3. Argumentação e metáfora conceptual: usos estratégicos do discurso político.............139 
3.3.1. Motivação retórica/argumentativa pelo viés da metáfora conceptual 148

3.3.1.2. Valores do ideal social nos processos referencial-metafóricos 154

3.4. Seleção de metáforas perante auditórios específicos e orientação argumentativa. 158

3.5. Metáforas conceptuais, expressões metafóricas e construção de sentido em discursos situados

3.6. Sequência de ações no discurso, usos da metáfora conceptual e do léxico 170

3.6.1. Função referencial e retórica da metáfora na organização discursiva .174

3.7. Metáfora e controle nos discursos de líderes políticos 176

3.8. Construção discursivo-metafórica da referência na política global 181

\section{CAPÍTULO IV}

4.1. Construção discursivo-metafórica da justiça social e da proposta de mudança política

4.1.1. Fórum Econômico Mundial (Davos, 2003) 186

4.1.2. Financiamento à Guerra Contra a Fome (Davos, 2005) 186

4.1.3. 59 Assembleia-Geral da ONU (Nova Iorque, 2004). 195

4.1.4. O Combate à Pobreza (China, 2004). 199

4.2. Metáfora e processo de referenciação nas negociações bilaterais e multilaterais: relação entre o eu e o(s) outro(s)

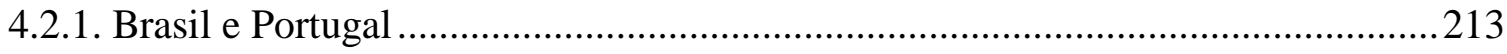

4.2.1.1. Cerimônia de Chegada a Portugal (2003) .....................................................213

4.2.1.2. Oportunidades de Novos Negócios e Investimentos Brasil-Portugal (2005).. 215

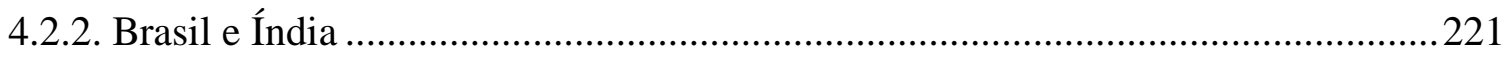

4.2.2.1. Fórum Empresarial Brasil-Índia (Mumbai, 2004)..........................................22 221

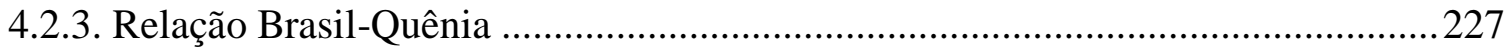

4.2.3.1. Seminário Empresarial Brasil-Quênia (Nairóbi, 2010)..................................227

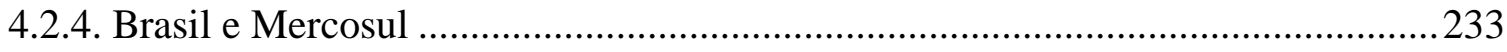

4.2.4.1. $39^{\circ}$ Reunião de Cúpula do Mercosul (2010) ..................................................233

4.3. Processos referencial-metafóricos da corrupção e da moralidade ...............................236

4.3.1. $4^{\circ}$ Fórum Global de Combate à Corrupção ............................................................2236

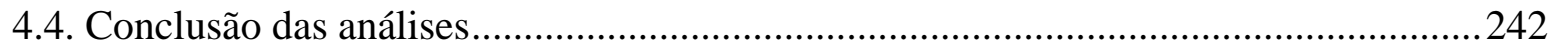

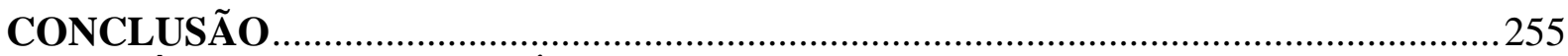

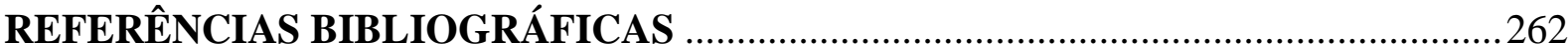

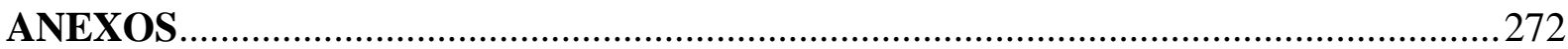

Pronunciamentos do ex-presidente da República Luís Inácio Lula da Silva, correspondentes à política externa de seu governo, inseridos em CD-ROM 
As pesquisas vinculadas às reflexões lógico-semânticas observam a questão da referência do ponto de vista da correspondência entre a língua e o mundo empírico - como o pressuposto das metáforas do espelho, do reflexo e do mapeamento que considera a atividade de referir como uma representação adequada da realidade (Rorty, 1980), e avalia a sintaxe em relação à sua capacidade de cartografar a ordem natural das coisas. (Cohen, 1977; Padley, 1985; Grace, 1987) ${ }^{2}$, entre outras. Recentemente, vários estudiosos passaram a analisar a referência em meio às práticas sociais, considerando-a atividade intersubjetiva, construção simbólica em que elementos psicossociais e situacionais estão presentes. Na relação com o mundo, ela é vista como, "a um só tempo, dialeticamente determinada e determinante, estruturada e estruturante, organizada e organizadora" (Koch, 2005b, p.08). Nesta perspectiva interacionista, sociocognitivista e discursiva, destacamos os demais trabalhos sobre a teoria da referenciação de: Koch (1996, 2001, 2003, 2005a, 2005b, 2006, 2008a, 2008b), além de Koch e Marcuschi (1998, 2003), Apothéloz (2003), Marcuschi (2001a, 2001b, 2002a, 2004, 2005, 2007), Mondada (2001, 2002, 2005a, 2005b), Mondada e Dubois (2003), entre outros.

Embora tenhamos em conta os significativos avanços dessa teoria, pontuando junto aos estudos da linguagem nos últimos anos, em razão de ter trazido para si a configuração complexa do homem, da língua e discurso, do mundo, motiva-nos a complexidade que ainda envolve esse objeto em constante transformação. Isto porque a conjuntura de uma sociedade globalizada, que proporciona acesso a informações múltiplas às pessoas de várias partes do mundo e necessidades sociais metamorfoseadas constantemente, imprime aos discursos de hoje, como o dos políticos em sua dimensão internacional, características específicas dessa nova ordem societal que se nos apresenta.

Em específico, os discursos políticos passaram a alcançar espaços ainda pouco explorados, principalmente, a partir da última década, em prol de alguns objetivos da política externa do governo do ex-presidente da República do Brasil Luis Inácio Lula da Silva. Levar informações a respeito do Brasil, de sua nação e de seu governo, ao continente asiático, ao africano, por exemplo, corresponde a uma ação discursiva peculiar e atual, na medida em que criar condições para que líderes mundiais e empresários com diferenças culturais construam

\footnotetext{
2 Apud. MONDADA, L.; DUBOIS, D. (2003).

COHEN, M. (1977). Sensible words: Linguistic pratice in England, 1640-1785. Baltimore: Jonh Hopkins.

GRACE, G. W. (1987). The linguistic construction of reality. London: Croom Helm.

PADLEY, G.A. (1985). Grammatical theory in Western Europe, 1500-1700: trends in vernacular grammar. Cambridge: Cambridge University Press.

RORTY, R. (1980). Philosophy and the Mirror of Nature. New Jersey: Princeton University Press.
} 
ou reconstruam conceitos, imagens de objetos de discurso relacionados a uma nação cognitiva e empiricamente distante, ou mesmo, levá-los a entender uma situação global a partir de um recorte enviesado axiologicamente, envolve reconhecer que, no mínimo, a referenciação dá-se por articulação específica de saberes intraculturais. Tais motivos fizeram-nos entender a necessidade de nos voltarmos para o exame da constituição de objetos de discurso e de suas categorizações e recategorizações, promovidas em espaços internacionais de circulação do discurso presidencial.

Nessa direção, pareceu-nos significativo observar a referenciação em um viés argumentativo, por entendermos que as mudanças históricas e sociais que englobam tais práticas políticas internacionais requerem o uso de estratégias argumentativas, por vezes, singulares, isto porque, uma vez que as circunstâncias interacionais se alteram, vale jogar com argumentos, pelos quais se torne possível suscitar forças pragmáticas, a fim de se alcançarem credenciamentos específicos, assim como compreendemos ocorrer nas diversas situações sociais em que um chefe de Estado, conforme a necessidade da política externa de seu governo, aparece publicamente e profere um discurso. Nestas ocasiões, há interesses diferentes entre os que compõem seu auditório - pessoas de seu país e do exterior; por conta disto, seus pronunciamentos fazem parte de um processo amplo e complexo, no qual estão envolvidos fatores de ordem nacional e global.

Além dessas razões que nortearam a realização deste trabalho, observamos que, embora autores - Charteris-Black (2011), Chilton (2004), entre outros - já se tenham detido à análise do discurso de chefes de Estado ou de governo com finalidades ligadas à argumentação, suas pesquisas não abarcaram a prática discursiva entre líderes mundiais em suas políticas externas, o que reforça nosso entendimento de que este campo mereça especial atenção.

Reflexões dessa ordem motivaram-nos a proceder ao desenvolvimento deste trabalho, a partir da observação dos processos referenciais delineados nos pronunciamentos presidenciais em reuniões específicas da política global e preocupamo-nos em conceber um arcabouço teórico que nos trouxesse subsídios para o exame dessa construção de objetos de discurso, em um viés argumentativo. Nesta acepção, primeiramente, foi a partir dos estudos da Teoria da Metáfora Conceptual (TMC) de Lakoff e Johnson (1980, 1999, 2003) e de Lakoff (1993) e de seus posteriores desdobramentos (Charteris-Black, 2006, 2007, 2008, 2009, 2011; Kovecses, 2003, 2005, 2009, 2010; entre outros) ligados aos da referenciação que encontramos uma maneira de buscar a compreensão de tal processo. 
O pressuposto de a metáfora conceptual estar nas mentes humanas e se materializar no léxico de uma língua (Lakoff e Johnson, 1980), transformada em discurso, e os de as associações de domínios díspares serem realizadas em várias culturas (Kovecses, 2005), de modo peculiar, em situações reais da vida, tal como ocorre no campo político (CharterisBlack, 2011), levaram-nos a observar a metáfora como fator significativo para os processos de referenciação.

O primeiro desafio com que nos deparamos para discutir os processos referenciais pelo viés da metáfora conceptual foi o de articular a dimensão linguístico-discursiva e sociocognitiva deste primeiro estudo às questões cognitivas já desenvolvidas pela Teoria da Metáfora Conceptual (TMC). Isto porque as pesquisas, realizadas após a TMC, as quais foram baseadas em situações reais de uso da metáfora, tais como as de Charteris-Black (2006, 2007, 2008, 2009, 2011), entre outras, reforçaram essa teoria, no sentido de terem comprovado a existência de metáforas nos discursos.

Assim, entendemos que um estudo da metáfora que se estenda ao da referenciação, ou vice-versa, deve-se ater à maneira como a seleção de domínios díspares colabora no processo efetivado nos discursos de categorizar e dar sentido aos vários objetos ativados na dinâmica discursiva e interacional. Foi seguindo nesta direção que fizemos dialogar as duas teorias e buscamos entender o lugar da metáfora como ponto de inter-relação (práxis, cognição e discurso), que se coaduna com a noção de referenciação.

Amparando-nos nessa discussão teórica, consideramos a prática de construção de objetos de discurso de modo metafórico como um caráter vivo, dinâmico, intersubjetivo, criativo e específico da ação humana de dar sentido ao mundo, organizando-o a partir de cenários discursivos diversos que conduzem olhares por meio de um encaminhamento sociocognitivo. Neste viés é que compreendemos estar esse processo vinculado à argumentação, inerente ao campo político e estruturante das práticas discursivas nele existentes.

A partir do que foi exposto, podemos dizer que as palavras não são portadoras de um sentido estrito. Ao contrário, na prática discursiva, elas são dotadas de ideologias (valores, crenças socialmente reconhecidos); portanto, revestem-se de carga argumentativa. Quando selecionadas no discurso, interagem com a situação na qual se inserem, com o cotexto e com a própria imagem do enunciador construída durante sua trajetória, possibilitando uma "plasticidade" (Guimarães, 1999); efeitos de sentido são efetivados, principalmente, no processo de constituição de objetos e podem motivar auditórios a agirem de determinado 
modo. Nesta concepção, pressupomos que estudar a metáfora no discurso possibilita também compreender um pouco dessa certa flexibilidade de sentido que a seleção lexical propicia, em razão de ser efetivada por pessoas com propósitos diversos.

É dessa maneira que acreditamos estar a atividade argumentativa presente nos processos referenciais e que referenciação, metáfora e argumentação fazem parte do complexo sistema de interação humana, em práticas socialmente estabelecidas. Isto porque, além de possibilitarem a progressão do texto e da interação, a ativação e a (re)ativação de objetos de discurso com sentido metafórico fazem parte de um jogo discursivo-argumentativo instaurado, conforme as condições específicas de produção.

A respeito desse entrelace entre referenciação, metáfora e argumentação, salientamos que outro desafio consistiu em conduzir nossa pesquisa de modo a desenvolver uma discussão teórica, em que pudéssemos apresentar os caminhos da argumentação na referenciação e na metáfora. Neste viés, selecionamos estudos nos quais seus autores tenham levado em conta alguns elementos comuns, tais como a relação entre o discurso e fatores culturais, históricos, psicossociais etc. Entre os estudiosos que vêm tratando de questões dessa ordem, destacamos Perelman e Olbrechts-Tyteca (2002 [1958]); Aquino (1997, 2003, 2005); Charteris-Black (2011).

Sobre esse ponto, quando nos referimos à argumentação, salientamos que os discursos formulados, ou pronunciados, por políticos enquadram-se em um domínio de prática social detentor de relações de disputas, cujo objetivo principal é a gestão de um poder. O político deve, pois, conquistar credibilidade e identificação; para tanto, torna-se necessário convencer e persuadir um número significativo de pessoas. Desta maneira, os discursos, no campo político, devem prezar por efeitos de verdade, de verossimilhança, já que a credibilidade alcançada será fator essencial para conseguir a adesão do auditório. Neste sentido, seguimos também a orientação teórica de estudiosos, como Chilton (2004) e Charaudeau (2006).

Com base nesse ponto de vista, o discurso cumpre importante papel no mundo da política, pois "é evidente que a atividade política não existe fora da prática da linguagem ${ }^{3}$ " (Chilton, 2004, p.06). É pelo discurso que se torna possível constituir espaços de discussão política e, ainda, chegar ao convencimento e à persuasão. Desta maneira, a despeito de as práticas discursivas serem providas de intencionalidade, estão repletas de estratégias argumentativas. Entre estas, estudos significativos já revelaram o papel argumentativo de

\footnotetext{
${ }^{3}$ Tradução livre: Is clear is that political activity does not exist without the use of language.
} 
metáforas conceptuais (Charteris-Black, 2011; Moreno, 2008); entretanto, não identificamos literatura específica que contemplasse tanto a argumentação quanto o discurso presidencial dirigido a líderes políticos mundiais.

Entendemos também que o modo como se constituem os discursos e as orientações argumentativas no campo político internacional não ocorre da mesma maneira que na política interna de um país. Por tal razão, compreendemos haver a necessidade de discutir a configuração específica que deu corpo aos pronunciamentos elaborados em prol de uma política externa brasileira. Nesta direção, não encontramos, na área dos estudos discursivos, pesquisas específicas do campo internacional da política. Assim, para que pudéssemos delinear o contexto situacional, procedemos a um diálogo entre as pesquisas do discurso político e as da área da ciência política e das relações internacionais (Vizentini, 2008; Almeida, 2003, 2004, 2006, entre outros). Ressaltamos que não nos propusemos a uma exploração acentuada dessas questões, mas sim conduzimos nossa discussão de modo a destacar informações importantes, cuja conjuntura estivesse estreitamente relacionada às condições específicas de produção dos pronunciamentos que compuseram o corpus que selecionamos para análise.

Nesse sentido, em razão de tais especificidades estarem relacionadas tanto às próprias características da política internacional quanto aos posicionamentos dos políticos que compõem a representatividade de um país, julgamos significativo considerar as características do campo global da política e do governo de Lula como condições que afetaram seus discursos de modo geral, tanto por haver objetivos singulares desse governo quanto por estas especificidades terem levado a expectativas e a especulações por parte de alguns auditórios acerca de certos credenciamentos, em termos de se saber com quem se está jogando e de que modo será conduzido o jogo.

A partir desses conceitos, verificamos que muito ainda há a se investigar no que concerne à metáfora como processo discursivo, principalmente, em relação ao fenômeno da referência associado ao campo da argumentação. Por tal razão, não objetivamos construir uma visão do todo, mas sim contribuir para que entendamos um pouco mais tal processo.

O ponto em questão, portanto, é examinar como a metáfora, vista como processo discursivo e sociocognitivo, pode colaborar nos processos de referenciação, possibilitando a construção de cenários discursivos que orientam argumentativamente um auditório específico. Assim também, observar como, por meio de uma linha referencial-metafórica, os pronunciamentos do ex-presidente Lula puderam fornecer condições de modificação de 
contextos (estruturas mentais) e motivações retóricas/argumentativas nas etapas dos discursos da política internacional, de maneira que as imagens metafóricas favorecidas nesse processo pudessem consistir em elementos significativos para as teses defendidas pelo ex-presidente da República do Brasil, conforme a configuração de cada encontro.

Nesse sentido, nossa pesquisa busca responder os seguintes questionamentos:

- Quais as especificidades dos pronunciamentos de Lula para criar força política e econômica do Brasil no âmbito internacional?

- Que tipos de metáforas são selecionadas nesses pronunciamentos e qual o caráter referenciador e retórico delas?

- Como se constituem as categorizações nos processos referenciais e metafóricos?

- Qual o papel das (re)categorizações referencial-metafóricas na construção dessas metáforas?

Esses questionamentos direcionaram os objetivos deste trabalho, que tem, então, por proposta central contribuir para o aprofundamento dos estudos sobre a referenciação pelo viés metafórico, em específico, no discurso presidencial da política internacional. Tal proposta desmembra-se em três objetivos específicos: i) observar quais metáforas se apresentam e que funções elas cumprem em relação às teses defendidas no discurso presidencial na política global; ii) detectar como se articularam as redes referenciais relacionadas a essas metáforas na organização discursiva; iii) examinar o encaminhamento argumentativo efetivado a partir da articulação das redes referenciais metafóricas.

Temos por hipótese que existem metáforas centrais, inter-relacionadas e alinhadas a uma tese específica, as quais norteiam a constituição de redes referenciais metafóricas singulares na organização discursiva. A articulação dessas redes permite que se visualize uma ampla cadeia metafórica de caráter referenciador, que pode orientar argumentativamente auditórios ora particulares ora universais, tanto em razão de reforçar o sentido metafórico (das metáforas centrais) quanto por conta de produzir sentido a valores abstratos a partir dos valores concretos, ativados por determinados domínios-fonte. Além do mais, a partir da proposta da lógica dos contêineres de Lakoff e Jonhson (1980), cremos que a referenciação se estruture pelo viés dos contêineres e se alinhe a outras metáforas orientacionais e às ontológicas. 
Pressupomos, ainda, que, por meio da articulação teórica proposta - Referenciação, Metáfora e Argumentação - possamos observar que a metáfora é tanto recurso de referenciação, que pode ser selecionado estrategicamente para fins argumentativos, quanto elemento estruturado e estruturante dos processos referenciais.

A hipótese e os objetivos de nossa pesquisa delineados desse modo encaminharam-nos a um estudo discursivo e sociocognitivo do pronunciamento presidencial na política internacional. Entre os procedimentos para a efetivação da pesquisa, selecionamos os pronunciamentos do ex-presidente da República, Luis Inácio Lula da Silva, em encontros com outros chefes de Estado e de governo. Como categorias de análises, elegemos: i) os tópicos entendidos como relevantes na agenda internacional do governo de Lula; ii) as metáforas relacionadas a esses tópicos e seus subtópicos; iii) os cenários discursivos, como categoria intermediária entre o domínio conceptual e os elementos lexicais que compuseram as redes referenciais específicas dos pronunciamentos.

No que se refere à coleta do corpus, selecionamos cinquenta pronunciamentos do expresidente da República, todos correspondentes à política exterior de seu governo, dentre os inúmeros disponíveis no Portal Oficial da Presidência da República Federativa do Brasil ${ }^{4}$, e recortamos dez. Tendo em vista o número elevado de pronunciamentos, por conta de terem ocorrido duzentas e sessenta e sete visitas a outros países, na condição de presidente eleito, precisamos buscar um critério para a seleção não só dos discursos, mas também dos tópicos que se apresentaram. Neste sentido, observamos que a política externa do governo Lula privilegiou a busca por novos mercados e o desenvolvimento de uma imagem do Estado e de seu governo alinhada ao viés humanístico, tendo a moralidade por fator significativo. Almeida ressalta que $(2004$, p.165):

No plano político, é evidente o projeto de reforçar a capacidade de "intervenção" do Brasil no mundo, a assunção declarada do desejo de ocupar uma cadeira permanente num Conselho de Segurança reformado e a oposição ao unilateralismo ou unipolaridade, com a defesa ativa do multilateralismo e de um maior equilíbrio nas relações internacionais. No plano econômico, trata-se de buscar maior cooperação e integração com países similares (outras potências médias) e vizinhos regionais.

Além de observarmos as especificidades da agenda política internacional do governo de Luis Inácio Lula da Silva, procedemos à seleção e à organização de nosso corpus de pesquisa, considerando os pressupostos de Marcuschi (2001c), para quem é preferível a

\footnotetext{
${ }^{4}$ http://www2.planalto.gov.br/

${ }^{5}$ Grifo do autor.
} 
qualidade à quantidade, a função em vez da forma, levando-se em conta também o indivíduo, a observação de dados autênticos e a contextualização. Adotamos, também, a proposta desse estudioso ao afirmar que, na área da linguagem, importa destacar a noção significativa de língua como construção social, ao invés daquela que a vê como objeto independente de fatores humanos, ideológicos e históricos. Para o autor, essa perspectiva modifica por si só o tratamento que deve ser dado aos corpora, e o modelo de ciência passa a ter como característica a multidisciplinaridade. O que importa, principalmente, é privilegiar o que se pretende com a investigação e, assim, observar os dados a partir do interesse investigativo do observador.

Dessa maneira, por ter sido a agenda internacional do governo Lula extensa e por não termos objetivado realizar uma pesquisa sistemática e quantitativa, para a constituição de nosso corpus, nossa análise foi qualitativa, embora não desprezemos algumas ocorrências quantitativas que nos forneceram pistas importantes para alcançarmos as respostas por nós almejadas. Nesta direção, consideramos as características da política externa de Lula e organizamos os pronunciamentos a partir de tópicos centrais: justiça social e mudança social; parcerias político-comerciais (bilaterais e multilaterais) e relação corrupção e moralidade.

A fim de buscar uma representatividade em relação aos discursos pronunciados pelo expresidente da República Luís Inácio Lula da Silva, direcionados a chefes de Estado e de governo, selecionamos dez pronunciamentos dentre os cinquenta coletados (Cf. anexos) e procedemos ao seguinte agrupamento:

- Justiça Social e mudança social: Davos (2003, 2005); ONU (2004); China (2004).

- Parcerias político-comerciais bilaterais e multilaterais: Brasil e Portugal (2003, 2005); Brasil e Índia (2004); Brasil e Quênia (2010), Brasil e Mercosul (2010).

- Corrupção vs. Moralidade: encontro global sobre corrupção em Brasília (2005).

Para alcançar os propósitos de nossa pesquisa e a partir da articulação teórica selecionada (Referenciação, Metáfora e Argumentação), propusemo-nos aos seguintes passos de investigação: exame das metáforas centrais selecionadas; detecção do momento em que elas aparecem nos pronunciamentos; observação das redes referenciais relacionadas a essas metáforas; análise da função argumentativa da articulação dessas redes metafóricas, na organização discursiva, levando em conta as condições específicas de produção. 
Os passos efetivados levaram-nos à seguinte organização do trabalho:

Primeiro Capítulo: Discurso, Referenciação e Metáfora. Foram discutidos e relacionados alguns posicionamentos, tais como o que se entende por língua, por referenciação e por metáfora, a fim de se debruçar sobre o papel referenciador da metáfora. $\mathrm{O}$ embasamento teórico consistiu dos estudos de Marcuschi (2001a, 2001b, 2002a, 2002b, 2004, 2005), Mondada (2001, 2002, 2005a, 2005b) Mondada e Dubois (2003); Koch (2005), entre outros, relacionados a pesquisas voltadas para o discurso, a metáfora e para suas especificidades sociais, históricas e cognitivas como as de Lakoff e Jonhson (1980, 2003); de Charteris-Black (2006, 2007, 2008, 2009, 2011), de Kövecses (2006, 2009), de van Dijk (2007, 2009, 2010), entre outros.

Segundo Capítulo: Condições de produção das práticas discursivas no contexto da política internacional. Neste capítulo, foram apresentadas e discutidas as especificidades do discurso político e, sobretudo, do presidencial nas relações políticas internacionais. Discorreuse sobre as propostas da diplomacia do governo de Lula e a respeito da situação do Brasil, após o governo de Fernando Henrique Cardoso, em termos de imagem de si e, automaticamente, do país. Foram relacionados estudos do campo da ciência política (Vizentini, 1999, 2008; Almeida, 2003, 2004, 2006, 2012) e do discurso político (Aquino, 1997, 2003, 2005; Van Dijk, 2010, Chilton, 2007, 2009, 2010; Montero, 2009, entre outros).

Terceiro capítulo: Caminhos da argumentação: a construção de mundos metafóricos no discurso político. Nesta parte, teorias do discurso político, metáfora e argumentação foram articuladas com o propósito de discorrer a respeito dos efeitos argumentativos que, por meio da metáfora, torna-se possível suscitar. A discussão apresentada nos capítulos 1 e 2 deram a base para tal discussão. Foram discutidos os preceitos dos seguintes estudiosos: Perelman e Olbrechts-Tyteca (2002 [1958]); Lakoff e Jonhson (1980, 1999, 2003); Aquino (1997, 2003, 2005); Kovecses (2003); Chilton (2007, 2009, 2010); Montero (2009); van Dijk (2010); entre outros.

Quarto capítulo: a partir da discussão apresentada nos capítulos anteriores, procedemos à análise do corpus, constituído por dez pronunciamentos do ex-presidente da República Luís Inácio Lula da Silva em Davos (2003, 2005), na Organização das Nações Unidas (2004), na China (2004), em Portugal (2003, 2005), na Índia (2004), no Quênia (2010), na Argentina, por conta da reunião de cúpula do Mercosul (2010) e em Brasília, no $4^{0}$ Fórum Global de Combate à Corrupção (2005). 


\section{CAPÍTULO I}

DISCURSO, REFERENCIAÇÃO E METÁFORA 
[...] ninguém pode despir-se de sua condição cognitiva para analisar sua condição cognitiva.

[...] o problema central não é saber se o mundo está pronto, mobiliado por alguma divindade, cabendo-nos captá-lo conceitualmente, ou se o mundo tem uma ordem dependente do mobiliário de nossas mentes repletas de verdades a priori, mas sim como a ordem seja qual for - é percebida, construída, comunicada e utilizada. Acredito que a ordem de nossos conhecimentos e das instituições que o suportam não é uma ordem natural, mundana. É uma ordem essencialmente cognitiva e interativamente semiotizada: uma ordem histórica e sócio-cognitiva. (Grifos do autor).

Marcuschi, 2005

Nas últimas décadas, pesquisas sobre a referenciação vêm revelando que a atividade de darmos sentido ao mundo consiste de uma maneira de agirmos sobre ele discursiva e sociocognitivamente. Tem-se mostrado, pois, que o caráter dinâmico da linguagem está relacionado aos construtos mentais compartilhados na práxis social. Neste viés, tendo em vista que esse agir sobre o mundo implica motivações diversas de ordem também cognitiva, interessa-nos, sobretudo, observar as possibilidades do dizer metafórico, nos e pelos quais construímos e reconstruímos versões públicas do mundo que, de certo modo, estão em nossas mentes e se transformam a cada interação.

Tal discussão tem como pressuposto que estudar a metáfora nos ajuda a entender não apenas a complexidade das mentes humanas e dos discursos, mas também colabora, especificamente, para a compreensão do processo de referenciação do ponto de vista argumentativo, uma vez que dar sentido a objetos de discurso a partir de outros socialmente reconhecidos, ativar múltiplas referências de modo a encaminhar olhares, despertar sensações, aproximar razão e emoção consistem em práticas discursivo-argumentativas motivadas e orientadas por metáforas subjacentes e realizadas por meio do processo dinâmico de construção de referências.

Portanto, entendemos que o estudo da metáfora do ponto de vista discursivo e (sócio)cognitivo propicia o distanciamento de uma visão representacional da linguagem e, consecutivamente, a observação de processos referenciais constitutivos e constituintes de práticas discursivas situadas. Trata-se de considerar, por um lado, que a compreensão do homem acerca de si e do mundo se relaciona a suas experiências individuais e coletivas e com 
a maneira como ele se posiciona em certas situações sociais; por outro, de conceber a metáfora como motivadora desse processo e, assim, cumpridora de papel significativo.

Tendo em vista esses apontamentos, cremos que se debruçar sobre o papel referenciador e retórico da metáfora implica, primeiramente, discutir e relacionar alguns posicionamentos, tais como o que se entende por língua, por referenciação, qual noção se tem de metáfora e em que lugar ela é observada, se no discurso e/ou no pensamento. Tal discussão é apresentada neste capítulo, a partir dos pressupostos dos estudos da Referenciação (Marcuschi, 2001a, 2001b, 2002a, 2002b, 2004, 2005, 2007, 2008; Mondada, 2001, 2002, 2005a, 2005b; Mondada e Dubois, 2003; Koch, 2001, 2005a, 2005b, 2006, 2008a, 2008b, entre outros) relacionados a pesquisas de outras disciplinas humanas e sociais, nas quais estão presentes o discurso e a metáfora como objetos e seus entornos sociais, históricos e cognitivos. Entre os estudiosos que vêm tratando de questões dessa ordem, destacam-se: Lakoff e Jonhson (1980, 1999, 2003); Charteris-Black (2006, 2007, 2008, 2009, 2011), Kövecses (2003, 2005, 2009, 2010), van Dijk (2007, 2009, 2010), O’Brien (2010), entre outros. Suas posições serão discutidas a seguir.

\subsection{Referenciação, discurso e sociocognição}

Embora seja indiscutível que a língua se estruture em vários planos, como o fonológico, o sintático, o semântico e o cognitivo, o fato é que todos estes se organizam no processo de enunciação. Torna-se, assim, possível afirmar que ela se manifesta em seu funcionamento e é sensível ao contexto - em seu sentido amplo, o situacional e o cognitivo (Marcuschi, 2008). Partimos, pois, de uma concepção de língua que vai além de um sistema transparente, de uma relação estruturada entre palavras e coisas, já que, nos processos discursivos, ela consiste de interação, de forma de ação situada, concretizando-se em usos textuais diversos e produzindo sentidos variados.

$\mathrm{Na}$ passagem da língua ao discurso, entendemos que a cognição cumpre papel significativo, já que o procedimento discursivo - que envolve intersubjetividade, seleções linguísticas e fatores pragmáticos - é constitutivo e indissociável do processamento cognitivo, como observa Morato (2005, p. 80):

[...] os processos de mediação entre linguagem e cognição são sóciohistoricamente constituídos; ambos os processos são forjados no 
interior de práticas sociais, não havendo possibilidades integrais de cognição ou domínios cognitivos fora da linguagem e nem possibilidades integrais de linguagem fora de processos interativos humanos.

Tal posicionamento também pode ser observado na afirmação de Koch (2008b, p. 202), para quem a língua está imbricada nas interações sociais, em que os participantes ativam modelos de mundo de caráter cognitivo: "A língua não existe fora dos sujeitos sociais que a falam e fora dos eventos discursivos nos quais eles intervêm e nos quais mobilizam suas percepções, seus saberes, quer de ordem linguística, quer de ordem sociocognitiva, ou seja, seus modelos de mundo".

Nessa abordagem, a referência caracteriza-se por ser uma construção coletiva e, ao mesmo tempo, individual de modos de dizer. Trata-se de construir discursivamente realidades, que não correspondem, especificamente, à objetiva - ao mundo empírico apartado das condições humanas de percepção, de valorização, de julgamento, de usos da linguagem até porque muitas de nossas referências textuais não têm correspondência no mundo externo. Nessa mesma direção, temos ainda que as intencionalidades diversas dos falantes fazem com que eles sejam motivados a encaminhar seus interlocutores a perceber objetos de discurso a partir de um viés.

Assim é que os objetos postos em discursos estão além destes; configuram-se em nossas mentes e são negociados nas interações sociais. Esta afirmação leva-nos a postular, com Marcuschi (2007, p. 70), que "não pensamos com as coisas, mas as coisas com base num sistema social e simbólico de muitos níveis de estruturação e operação. Daí podermos falar de coisas mesmo quando ausentes e inexistentes" ${ }^{\text {. }}$

Nessa perspectiva, proposta pelos estudos da referenciação (Koch, 2005a, 2005b; Mondada e Dubois, 2003; Marcuschi, 2001a, 2002a, 2005, 2007, entre outros), considera-se que as pessoas constituem sentido sobre aquilo que as cercam no processamento discursivo e entende-se que tal constituição de imagens mentais e discursivas - baseadas nas atividades do cotidiano, da literatura, da política, da ciência etc. - corresponde à formulação de "objetos de discurso" (Mondada e Dubois, 2003), em oposição à noção de objetos do mundo.

Assim é que os objetos de discurso não são considerados objetos do mundo, ou seja, não se constituem pela remissão linguística a uma entidade autônoma, externa da prática

\footnotetext{
${ }^{6}$ Grifos do autor.
} 
discursiva (Roncarati, 2010, Mondada, 2001). Eles são, ao mesmo tempo, unidades mentais e linguísticas, as quais, como produtos culturais, são condicionadas, reunidas e organizadas de determinada maneira na dinâmica discursiva.

Marcuschi $(2005,2007)$ corrobora tal posição e ainda afirma que todos os objetos de conhecimento são objetos de discurso, pois a imagem que temos construído do mundo e de nós mesmos é organizada discursivamente e é sobre ela que nos debruçamos na tentativa de refletir e de lhe dar algum sentido:

O mundo de nossos discursos (não sabemos como é o outro) é sóciocognitivamente construído. O discurso é o lugar privilegiado da designação desse mundo. A própria ordem de reflexão sob o ponto de vista de sua organização e dependências lógicas é uma construção predominantemente discursiva. (MARCUSCHI, 2005, p. 69)

Nota-se que essa noção de referenciação vai de encontro a posicionamentos tradicionais e olhares dicotômicos a respeito da noção de referência, como: a relação objetiva entre língua e realidade empírica/concreta vs. o subjetivismo radical; a concepção de estabilidade referencial vs. a desestabilidade generalizada. A respeito dessas noções distintas entre referenciação e referência, é também Marcuschi (2005) quem afirma que, em uma abordagem interacionista e não referencialista da língua, privilegiam-se os encontros sociais, nos quais os discursos estão presentes. São nessas práticas sociais e discursivas que os participantes elaboram versões públicas do mundo estabelecidas por meio de ajustes, de acordos e desacordos entre os participantes, ou seja, os objetos de discurso, como o próprio discurso, serão sempre cognitiva e socialmente coproduzidos.

Considera-se, assim, que os interlocutores ativam conhecimentos prévios a respeito da situação social na qual se encontram, a fim de que seus objetivos sejam alcançados. Em outras palavras, ao interagirem, cada qual tem expectativas em relação ao encontro e aos outros participantes e utiliza certos conhecimentos e experiências no momento da elaboração dos enunciados e da compreensão dos discursos alheios. Tal posicionamento nos possibilita afirmar que o processamento cognitivo é estratégico e, consecutivamente, o textual-discursivo também o é (Koch, 2005a).

Tanto as estratégias cognitivas - ou estratégias de uso do conhecimento - quanto as textual-discursivas dependem dos objetivos do interlocutor, da quantidade de conhecimento de que ele dispõe sobre o(s) outro(s) participante(s) e a respeito da situação social, de suas 
crenças e de seus valores. Em decorrência da configuração do encontro, o locutor ora pode deixar algo implícito no texto, por considerar que tal lacuna possa ser preenchida pelo interlocutor a partir de seus conhecimentos prévios, ora se utilizar de outras estratégias. Os procedimentos dependerão, portanto, da interação de diversas ações e reações praticadas pelos participantes naquela situação ou efetivadas em outros momentos, os quais foram armazenados na memória.

Essa perspectiva - em que há o postulado de a construção da realidade consistir de uma atividade discursiva e cognitiva de enquadre social - pode ser relacionada novamente à posição de alguns estudiosos (Morato, 2005; Vereza, 2010, entre outros), os quais afirmam que toda cognição é sociocognição, na medida em que construímos aquilo que nos cerca a partir das relações sociais.

A respeito do entrelace existente entre cognição, discurso e interação, convém ainda salientar que os contextos cognitivos dos participantes alteram-se a cada encontro (Aquino, 1997), a partir das informações em evidência e da maneira como eles estabelecem as negociações de sentido na situação interacional. Uma vez que ocorre modificação constante nos modelos mentais dos participantes nas diversas trocas sociais nas quais eles interagem, parece-nos coerente dizer que as imagens constituídas de certos objetos de discursos não estão prontas, acabadas, mas sim em constante transformação, assim como está o material linguístico, utilizado para construí-las.

Pelo que se expôs, ou seja, ao se caracterizar o referente textual não como o real, mas sim como uma unidade sociocognitiva de construção sensível a ajustes e a acordos, uma questão central apresenta-se de modo significativo na produção de sentido desses denominados objetos de discurso, que é a função da metáfora nesse processo. A princípio, pode-se acrescentar que, nas práticas sociocognitivas de construção de realidades discursivas, a metáfora cumpre papel relevante, se considerarmos o postulado de que ela faz parte de nossa percepção de realidades empíricas e está imbricada em nosso processo de interpretação, como afirmam Lakoff e Johnson (1980, 2003).

Esses estudiosos, ao assumirem uma abordagem cognitivista sobre a metáfora, já em uma síntese experiencialista, também se afastam dos olhares radicais do objetivismo e do subjetivismo e ressaltam que os seres humanos compreendem o mundo por meio do contato que se tem com ele e isto é marcado linguisticamente. 
A presença de formulações linguísticas metafóricas, denominadas expressões metafóricas por Lakoff e Johnson (1980, 2003), pode comprovar essa natureza sociocognitiva de apreensão e de compreensão da realidade empírica que nos cerca e que de modos diversos construímos discursivamente. É a partir deste ponto, o qual envolve linguagem, práxis e pensamento, que relacionamos os estudos dos processos referenciais aos da metáfora (sócio)cognitiva, para discutirmos o papel da metáfora na referenciação.

Por acreditarmos que a referenciação se realiza na enunciação, ou mesmo, "pode ser considerada um ato de enunciação" (Morato, 2005, p.80), a discussão do papel referenciador da metáfora requer um desafio que consiste de articular a dimensão linguístico-discursiva à (sócio)cognitiva deste objeto de estudo, ou seja, de explorar o caráter discursivo e textual da metáfora sem desconsiderar as questões cognitivas já desenvolvidas pela Teoria da Metáfora Conceptual (TMC), uma vez que os estudos, posteriormente realizados a partir da TMC, os quais foram baseados em exemplos reais de uso da metáfora, como os examinados no campo da política, em uma perspectiva também social (Charteris-Black, 2006, 2007, 2008, 2009, 2011, entre outros), não contestaram tal teoria, mas a reforçaram, no sentido de terem comprovado a existência de metáforas conceptuais nos discursos examinados.

\subsection{Abordagem discursiva, cognitiva e interacional da metáfora e sua função referencial}

Sabe-se da existência de inúmeros estudos acerca da metáfora desenvolvidos a partir de várias perspectivas, desde uma visão aristotélica tradicional até as mais recentes teorias a respeito dela. Por ter sido amplamente pesquisada, há mais de dois mil anos, várias definições e conceitualizações foram propostas; entretanto, ainda hoje, a noção de metáfora é controversa. Fato é que, como afirma Vereza (2010), observar a metáfora como figura de linguagem ainda corresponde a um olhar predominante em muitas pesquisas acadêmicas e, aparentemente, é uma visão do senso comum, na medida em que é possível observá-la em textos escritos e falados, mesmo que não se tenha um critério teórico de análise.

Assim, a visão mais tradicional de metáfora é a de figura de linguagem. Acredita-se que tal fato possa ser explicado pela questão ainda muito discutida sobre o sentido literal da linguagem em oposição ao figurado e por se considerar a metáfora um fenômeno especificamente linguístico, e a língua, independente das interações sociais e de seu componente cognitivo. 
Para este trabalho, interessa-nos uma abordagem, como já mencionamos, que torne possível relacionar a dinâmica do discurso à dimensão sociocognitiva que a envolve. Um estudo da metáfora que se estende a sua função referencial, esta do ponto de vista da referenciação, deve-se debruçar sobre o modo que ela colabora no processo, efetivado por participantes em um dado encontro, de categorizar e de compreender o mundo e que os leva a selecionar e a organizar elementos linguísticos que podem direcionar sentidos metafóricos na dinâmica discursiva e interacional.

A partir disso, vale-nos ressaltar o pressuposto de Marcuschi (2005, p.49), ao citar Geertz (1989) que afirma "O homem é uma animal amarrado a teias de significado que ele mesmo teceu"7 e discorre sobre a necessidade de se analisar essa teia de significados, levando em conta nossa condição de indivíduos semióticos e sociocognitivos. Neste viés, o papel da cognição mais uma vez se marca como significativo nesse processo de construção de sentidos e de mundos discursivos e mentais. Em razão de acreditarmos na ideia de não haver representações mentais fixas, os estudos sobre a metáfora que mais se ajustam a nossa proposta correspondem àqueles que se distanciam de uma noção, especificamente, linguística e a consideram também parte de nosso pensamento e de nossas interações sociais.

Marcuschi (2007 [1975, 1978], p.122) refere-se ao caráter cognitivo da metáfora, já em seus trabalhos da década de 70 . O autor destaca que:

[...] embora ainda não haja uma ontologia da metáfora, pode-se supor que nos fundamentos da metáfora estão bases da experiência empírica que a consciência acumula reserva para elaborar estruturas e universos além da própria experiência.

Mesmo que tenha havido discussões sobre o caráter cognitivo da metáfora, como consta na afirmação anterior, a virada cognitiva ocorre de maneira mais efetiva ${ }^{8}$, a partir da Teoria da Metáfora Conceptual (TMC) - desenvolvida pelo linguista Lakoff e pelo filósofo Johnson (1980) e advinda, principalmente, da noção de frame dos estudos de Reddy (1979) ${ }^{9}$.

\footnotetext{
${ }^{7}$ In: GEERTZ, Clifford. (1989). A interpretação das culturas. Rio de Janeiro: Livros Técnicos e Científicos Editora.

${ }^{8}$ Outros estudiosos, como Richard (1936), Ricouer (2005 [1975]), consideraram a metáfora como figura do pensamento e se afastaram de um olhar sobre ela, especificamente, voltado à língua, na perspectiva da representação. Como também, de acordo com Kövecses (2005), antropologistas sempre tenderam a observar a metáfora como um poderoso dispositivo conceptual; entretanto, na TMC, esta noção foi sistematizada.

${ }^{9}$ A noção de metáfora como parte do sistema comum do pensamento e da linguagem advém, principalmente, de Reddy (1979), que foi o primeiro estudioso a demonstrar esse conceito por meio de uma análise linguística
} 
De acordo com esta teoria, é devido ao nosso sistema conceptual, metafórico por natureza, que podemos nos relacionar com o mundo e com as situações diárias.

Para esses estudiosos, a metáfora faz parte de nossa percepção de realidades empíricas e está imbricada em nosso processo de interpretação. Neste sentido, conceitualizamos de maneira metafórica o que está ao nosso redor e, consecutivamente, apresentamos pistas linguísticas desses conceitos nos discursos sociais. Nas palavras de Lakoff e Johnson (1980, p.5): “O conceito é estruturado metaforicamente, a atividade é estruturada metaforicamente e, consequentemente, a linguagem é estruturada metaforicamente" ${ }^{10}$. Esses autores da TMC criticam a dicotomia literal $v s$. metafórico apresentada no estudo aristotélico e nos tradicionais (Bally, 1951; Black, 1975, entre outros). Para eles, a compreensão de uma metáfora, em um texto, não se efetiva após o entendimento literal, mas sim ocorre em um processo pelo qual se aciona de maneira automática a metáfora conceptual já existente em nossa mente.

Nessa abordagem, ressaltamos que o termo metáfora é utilizado de maneira diferente daquele dos estudos tradicionais; enquanto naqueles ela é entendida como relação de semelhança, nas pesquisas da metáfora cognitiva, refere-se ao cruzamento entre domínios distintos advindos da experiência humana e da natureza de nossos corpos físicos. Já em relação à realização linguística desses domínios, enfatizamos, mais uma vez, que o termo utilizado corresponde à expressão metafórica.

A respeito desses domínios conceptuais, a TMC refere-se a dois tipos: o domíniofonte, que consiste, geralmente, de um conhecimento oriundo de uma experiência empírica a partir do qual conceitualizamos metaforicamente algo pertencente a um domínio de outra natureza, e o domínio-alvo, aquele que construímos de maneira metafórica por meio do primeiro. Em outras palavras, um domínio de natureza abstrata (como TEMPO, AMOR ${ }^{11}$ ) pode ser construído a partir de experiências concretas já legitimadas socialmente, como VIAGEM. Salientamos que um domínio-fonte pode servir a vários domínios-alvo.

Nessa perspectiva mais ortodoxa da TMC, a linguagem passa a ser observada como fonte empírica de evidência - ou seja, nela, ocorrem pistas (expressões metafóricas) para se

rigorosa. Para o autor, os falantes do inglês utilizam uma conduta metafórica, ou seja, suas ideias são como objetos inseridos em um contêiner (nas palavras) e enviados para os seus interlocutores por meio da comunicação. Os estudos de Reddy (op. cit) são ampliados na Teoria da Metáfora Conceptual (Lakoff e Johnson, 1980, 2003), principalmente, no que concerne ao uso que fazemos da metáfora em nosso dia a dia e à ideia de a utilizarmos de maneira convencional e, por vezes, inconsciente.

10 Tradução livre. The concept is metaphorically structured, the activity is metaphorically structured, and, consequently, the language is metaphorically structured.

${ }^{11} \mathrm{Na}$ Teoria da Metáfora Conceptual (TMC), grafam-se as metáforas conceptuais, aquelas que conceitualizam algo metaforicamente, em caixa alta. 
observar metáforas - cumprindo, assim, um papel secundário. A respeito disto, houve muitas críticas, sobretudo, pelo fato de os autores terem utilizado, em boa parte de seus estudos, evidências linguísticas artificiais, ou seja, não reais.

Após a TMC, vários estudos vêm contribuindo para o entendimento da natureza cognitiva, linguística e social da metáfora, como os de: Gibbs, 1994, 1999; Mussolf, 2004; Charteris-Black, 2006, 2007, 2008, 2009, 2011; Kövecses (2003, 2005, 2009, 2010); entre outros. Esses autores seguem alguns pressupostos da teoria conceptual; entretanto, em algumas considerações, enveredam por outros caminhos. Eles enfatizam a importância da análise da recorrência de seleções linguísticas metafóricas - as quais constroem discursivamente metáforas convencionais ou novas - em situações interacionais reais e específicas e partem do pressuposto de que a metáfora consiste também de um fenômeno social.

Nas pesquisas, em que a metáfora conceptual foi observada a partir de exemplos reais, não houve, de maneira geral ${ }^{12}$, refutação de alguns pressupostos da TMC, pelo contrário, o exame de ocorrências reais da linguagem deu evidência sólida da presença de metáforas conceptuais particulares, fortalecendo, consecutivamente, a Teoria da Metáfora Conceptual.

Tais resultados, para Vereza (2010), mostram que a metáfora da língua em uso é motivada por metáforas subjacentes. Para a autora, essa hipótese baseada na cognição pode esclarecer várias ocorrências de metáfora na linguagem, as quais, anteriormente, pareciam ser, exclusivamente, produto da criatividade individual ${ }^{13}$; entretanto, ela enfatiza que muitos casos de metáfora na linguagem parecem resistir a essas explicações baseadas em uma sistemática de representações mentais, como ocorre naqueles em que metáforas dependem de fatores contextuais e cotextuais para serem produzidas e compreendidas. Para a autora, o estudo destes casos também não revela insuficiências da TMC, pelo contrário, pode até mesmo fornecer outras evidências da teoria.

Assim, por um lado, a necessidade de se considerar as características do contexto situacional e do cotexto, parece, novamente, deslocar o lócus da metáfora para a linguagem, esta agora entendida como discurso. Por outro lado, estudar a metáfora no discurso corresponde a considerar os fatores (sócio)cognitivos que fazem parte deste processo, como já

\footnotetext{
${ }^{12}$ Um dos posicionamentos diferentes desses estudos consiste, por exemplo, na afirmação de Gibbs (2006) de a metáfora conceptual ter muito mais a função de colaborar para a compreensão de metáforas linguísticas, do que para criá-las, como postulado na TMC.

${ }^{13}$ Na perspectiva tradicional e aristotélica da metáfora, esta foi considerada como um dom de gênio, advindo da criatividade do indivíduo.
} 
afirmaram Fauconnier e Turner (2003) sobre a necessidade de não se dicotomizar os processos cognitivos dos sociais, fatores interligados para a construção de sentido, uma vez que, como já mencionamos, a cognição é socialmente situada.

Dessa maneira, a análise discursiva da metáfora não deve considerá-la, especificamente, como uso individual da linguagem, pois estão implicadas, nessas produções, representações socialmente compartilhadas e cognitivamente inscritas. Neste sentido, pode-se afirmar que o uso de expressões metafóricas é situado e estabelece relação dialética com as representações mentais oriundas de uma dada cultura (Charteris-Black, 2006, 2007, 2008, 2009, 2011; Kövecses, 2005, 2009; Vereza, 2010).

Entre os estudiosos que partem dessa abordagem, destacamos Charteris-Black (2006), para quem a metáfora evidencia a capacidade do cérebro humano de perceber relações similares, ou mesmo, nossa habilidade de encontrar o similar naquilo que não é; e isto, para ele, não deixa de ser um pensamento criativo tanto de quem a usa quanto de quem a precisa interpretar. O autor afirma que a metáfora só pode ser entendida se levarmos em conta suas dimensões semântica, pragmática e cognitiva.

Ele ainda argumenta que a metáfora não pode ser definida por um simples critério, que a observa da mesma maneira em todas as circunstâncias da vida, uma vez que seu uso se altera conforme os objetivos dos participantes inseridos em um contexto situacional específico e, também, pelas experiências que eles possuem dessas situações.

Assim, ao mesmo tempo em que o desenvolvimento de um conceito envolve seleções linguísticas, a seleção de uma metáfora também pode ser uma questão de escolha, ou seja, uma estratégia. Nas palavras do autor (op. cit., p.2):

Metáfora só pode ser explicada pela consideração da interdependência das dimensões semântica, pragmática e cognitiva. Isto é a porta de entrada pela qual maneiras persuasivas e emocionais de pensar sobre $\mathrm{o}$ mundo moldam a linguagem que usamos e pela qual nossos pensamentos a respeito do mundo são moldados pela linguagem em uso. $^{14}$

\footnotetext{
${ }^{14}$ Tradução livre. Metaphor can only be explained by considering the interdependency of its semantic, pragmatic and cognitive dimensions. It is the gateway through which persuasive and emotional ways of thinking about the world mould the language that we use and through which our thoughts about the world are moulded by language use.
} 
Também Kövecses (2009) considera a importância de relacionar o uso da metáfora às especificidades do contexto situacional e afirma que os seguintes fatores cumprem papel significativo nas produções discursivas metafóricas: o contexto linguístico imediato (cotexto); o que sabemos sobre as entidades participantes do encontro (os interactantes e o tema/tópico); os entornos físico e social; o contexto cultural.

A respeito do primeiro fator, o cotexto, esse estudioso propõe que as formulações metafóricas podem ser selecionadas de maneira coerente com as informações contidas no enunciado, tal como quando o enunciador leva em conta as características dos referentes textuais ativados e escolhe, entre as várias possibilidades de dizer, termos metafóricos interligados, do ponto de vista semântico e cognitivo, a esses objetos de discurso. Um exemplo apresentado pelo autor refere-se às formulações de manchetes, cujos tópicos discorridos versam sobre futebol. Nestes casos, são frequentes construções da metáfora da derrota ou da vitória, utilizando-se de formulações metafóricas baseadas nos nomes dos times, como ocorreu em Clemson cooks Rice (Clemson cozinha Arroz).

Nessa formulação indicada por Kövecses (2009), partiu-se do nome do time Rice, para dar sentido metafórico ao jogo em pauta. Selecionou-se o verbo Cook, que faz parte de um conhecimento socialmente partilhado (comer arroz, cozinhar arroz, colher arroz), de modo que associações pudessem ser feitas entre esse domínio-fonte e a situação imediata (jogo entre Clemson e Rice), surtindo efeito de humor provavelmente. Assim, a metáfora é marcada linguisticamente conforme as características do enunciado e, como se pôde observar, pelo uso de verbos relacionados ao nome próprio de um objeto de discurso, acordado por determinado grupo social como, no caso do exemplo do autor, o substantivo Arroz.

A seleção linguística metafórica pode estar de acordo também com o segundo fator apontado por Kövecses (2009): as informações que o enunciador tem a respeito dos interactantes do encontro e dos temas abordados. Relacionando este posicionamento à questão da referência, é possível afirmar que, se há diversas maneiras de construir discursivo e metaforicamente realidades empíricas - fatos, pessoas etc. - o locutor pode fazer uso dos conhecimentos que ele possui de seu interlocutor, do referente textual, do tópico ou subtópico em questão, ou mesmo, de si próprio para escolher palavras ou expressões e efetivar, assim, efeitos de sentido metafórico.

Isso indica a possibilidade de se selecionar metáforas de modo estratégico. Em específico, trata-se de um tipo de estratégia de uso do conhecimento. Tal posição remete-nos, novamente, à afirmação de Koch (2005) de que o processamento cognitivo e o textual- 
discursivo são utilizados estrategicamente pelos participantes de uma situação social específica, e à de Charteris-Black (2006) a respeito de ser a metáfora uma questão de escolha do falante, conforme seus propósitos argumentativos e interacionais, pelo fato de ela ter potencial para mover (persuadir) o outro.

Dessa maneira, podemos conceber que a metáfora conceptual está estreitamente ligada à referenciação, em razão de entendermos que a construção de objetos de discurso se realiza nos discursos e nos processos mentais, que são, em sua maioria, metafóricos por natureza. Seguindo nessa direção, embasamo-nos no postulado de a metáfora - por estar presente em nossos modelos de mundo e por ser um processo analógico, pelo qual se entende um conceito em termos de outros - fazer-se presente na atividade de mobilização dos vários tipos de conhecimento de ordem cognitiva, linguística e pragmática, na qual está imbricada a construção de sentido dos objetos de discurso, sensíveis a todos esses elementos e aptos a receberem ajustes conforme os propósitos de quem os seleciona.

Como se nota, essa perspectiva mais recente de observação da metáfora coaduna-se com os pressupostos da referenciação no diz respeito à relação indissociável entre língua, cognição e práxis (entendida como fatores históricos e culturais de interação) e isto nos permite conceber a metáfora como parte integrante do processo de construção conjunta de realidades discursivas, no qual se mobilizam modelos mentais de mundo.

Com efeito, é possível considerar - como já alguns estudiosos identificaram em suas pesquisas (Charteris-Black, 2006, 2011; Moreno, 2008; Chilton, 2004; entre outros) - que, em vários casos, existem metáforas conceptuais subjacentes, as quais organizam a representação e a categorização do mundo e, por conta disto, entendemos que elas motivam o processo de construção de objetos de discurso (Cf. p. 32), mas isto, mais uma vez, não orienta a afirmação de existir um construto linguístico e metafórico pronto, único, invariável e aplicável em qualquer circunstância social, uma vez que, levando-se em conta a dinâmica discursiva, quando escreve ou fala, o locutor tem em mente os interlocutores e isto já influencia a seleção do material linguístico e de sua organização. Entende-se, portanto, que a metáfora pode ser utilizada de modo singular, dependendo, até mesmo, da criatividade de quem a seleciona. Neste viés, Marcuschi $(2007$ [1975, 1978]) destaca que a metáfora está presente nos modelos de mundo dos indivíduos e fundamenta-se em sua capacidade cognitiva e criativa.

Diante dessas observações, acredita-se que as metáforas possam ser selecionadas, reunidas e organizadas na dinâmica discursiva e colaborar, em específico, no processo referencial, de modo a orientar, a enfatizar e a privilegiar olhares conforme uma determinada 
proposta de sentido e de acordo com as especificidades das situações interativas. É neste ponto que seu lócus deve ser entendido como inter-relação funcional, associando-se a tais afirmações as posições de Morato e Koch (2007), Morato (2005), Marcuschi (2008), Koch (2008a) a respeito da relação estreita entre linguagem e cognição socialmente constituída, por nós já discutida.

Além do mais, o fato de ela estar ligada às crenças e aos valores de determinados grupos, ou seja, de ser um produto da história de certas sociedades (Kövecses, 2005; Charteris-Black, 2011), também nos orienta a observar a metáfora conceptual como processo intrínseco à referenciação, à construção de objetos de discurso. Transferir os valores de um domínio a outro corresponde a um modo de viabilizar o entendimento acerca de objetos de discurso delineados no desenvolvimento do discurso; portanto, a partir do que expusemos, é possível pressupor que, no processo de referenciação, em boa parte das vezes, subjazem metáforas conceptuais que orientam e motivam redes referenciais específicas.

Se propomos que uma abordagem discursiva e social da metáfora também pressupõe a metáfora conceptual como significativa no processo de construção de sentidos e, neste trabalho, em específico, de objetos de discurso, entendemos a necessidade de discutir tais metáforas conceptuais de modo mais pontual.

\subsubsection{Metáfora conceptual na construção sociocognitiva e discursiva de referências}

Conforme apresentamos no item anterior, a contribuição mais significativa de Lakoff e Johnson $(1980,2003)$ para os estudos da metáfora foi a denominada virada cognitiva, na qual os autores romperam o olhar tradicional, especificamente, linguístico sobre a metáfora, entendendo-a como parte do pensamento. Posteriormente, embora alguns autores (Kövecses, 2005; Charteris-Black, 2011; entre outros) tenham estendido os conceitos da TMC para uma dimensão social e discursiva, o fato é que, por meio dessas pesquisas, puderam comprovar com evidências empíricas a presença de metáforas subjacentes nos discursos que circulam na sociedade.

De modo geral, essas metáforas conceptuais fundamentam várias formulações linguísticas presentes no cotidiano e, por isto, por vezes, passa despercebido esse caráter metafórico. Conforme Vereza (2007, p.115), “haveria, dessa forma, uma ‘superposição’ de 
uma experiência já incorporada e linguisticamente determinada a uma outra experiência a ser mapeada pelo pensamento e pela linguagem".

Outra especificidade da Teoria da Metáfora Conceptual consiste no processo de legitimação - linguística, social e cognitiva - ou seja, de convencionalização de conceitos, cujas associações de domínios devem ser legitimadas linguisticamente, para que, assim, passem a fazer parte de nosso modo de dar sentido àquilo que nos cerca. Um integrante de um grupo ou de uma sociedade, em contato com mundo, compreende um determinado conceito por meio de outro já estabelecido, interpretando a realidade empírica conforme suas experiências. Essas conceituações são organizadas metaforicamente por meio de um amplo sistema em que há milhares de mapeamentos cruzados.

Nesse processo, conforme Vereza (2007, p. 115), a linguagem cumpre importante papel na retificação da metáfora, "uma vez que é mediante sua relação com a metáfora que os vários sentidos dados à experiência são construídos e, ao mesmo tempo, constituintes. Pela linguagem, a metáfora determina não só uma forma de expressar o real, mas, principalmente, de construí-lo social e subjetivamente”. É neste viés, portanto, que se postula estar a metáfora relacionada, de maneira intrínseca, ao processo de construção de sentido dado na e pela linguagem.

Foram apresentadas por Lakoff e Johnson três tipos de metáforas conceptuais: orientacional, ontológica e estrutural. As características de cada uma, bem como suas ligações ao processo referencial, serão discutidas a seguir.

\section{- Metáforas orientacionais}

Orientamo-nos, no mundo, a partir de uma visão espacial (corpo/espaço), em associação ao conceito de limite (espacialização). Entre as possibilidades de orientação, estão as noções de alto-baixo; dentro-fora; frente-trás; central-periférico; profundo-superficial.

Sobre essas orientações, na cultural ocidental, frequentemente, ouvimos determinadas expressões que remetem a situações negativas, como o termo down em contraposição a up (do inglês norte-americano). No Brasil, por exemplo, há formulações que apresentam contraste entre os conceitos positivo (alto) vs. negativo (baixo): "baixo astral”, "levantar o ânimo" etc., como também, não é difícil encontrar tal noção espacial em formulações linguísticas com função referencial ou dêitica, pelas quais se torna possível apresentar juízos de valor, como 
nas relações: alta sociedade $v s$. baixa sociedade; ela está nas nuvens $v s$. ela caiu em um buraco; ele está à margem da sociedade (noção de inclusão e exclusão social), entre outras.

Como se pode observar, nessas orientações metafóricas, estão imbricados valores, os quais podem variar de uma cultura a outra. Isto é observado por Lakoff e Johnson (1980), como já indicamos, quando afirmam que as metáforas de uma sociedade são coerentes com seus principais valores, principalmente em relação à espacialização. Este posicionamento embasa-se no fato de haver determinadas visões de mundo de tal maneira enraizadas em uma cultura que são refletidas nos discursos presentes na sociedade. Entre as formulações linguísticas indicativas de tais posicionamentos e destacadas pelos autores, tem-se a seleção “O futuro será melhor", em que se apresenta o conceito de progresso (relação entre o presente e o futuro ${ }^{15}$ ).

\section{- Metáforas ontológicas}

As metáforas ontológicas, por sua vez, ocorrem quando fenômenos de domínios abstratos são apresentados com limites, como é o caso da coisificação e da personificação entidades não humanas que, no discurso, são expostas com características específicas dos seres humanos ou de objetos empíricos. Assim, conforme Lakoff e Johnson (1980), por meio dessas metáforas, torna-se possível compreender e construir uma representação mental de algo proveniente do mundo abstrato, a partir de experiências com o que é concreto.

A esse respeito, Vereza (2007, p.121) afirma que:

As metáforas ontológicas surgem da necessidade humana de se apreender e dar algum sentido àquilo que não seria apreensível sem uma 'interferência' conceitual organizadora da experiência, o que significa, inevitavelmente, a entificação de certos fenômenos. ${ }^{16}$

As metáforas ontológicas colaboram na atividade de compreensão de um real, não préexistente, mas construído social e cognitivamente, tornando-o perceptível ao homem e, no discurso, marcam-se em algumas ações, como a de referir, a de quantificar, a de definir propriedades e causas, a de estabelecer metas. Neste viés, ao tornar um elemento abstrato, debruçando-se sobre ele e o tomando como objeto, o indivíduo é capaz de agir sobre este e de

\footnotetext{
${ }^{15}$ Tradução livre de "The future will be better".

${ }^{16}$ Grifo da autora.
} 
construí-lo de alguma maneira, como apresentar certas características, medir sua intensidade (discutir seu estado) etc.

Do ponto de vista discursivo e sociocognitivo, entendemos que coisificar um elemento abstrato faz que este se torne um objeto do pensamento e do discurso, possibilitando, assim, que ele seja passível de ajustes na dinâmica discursiva que o envolve. Tomemos como exemplo parte do texto de Camões "O amor é fogo, que arde sem se ver". Nesta formulação, trata-se o amor como algo externo ao homem e verifica-se a tentativa de dar sentido a essa entidade por meio da associação entre o sentimento e o fogo a partir de um conhecimento específico que se tem deste objeto, que é a sensação de ardor, advindo da experiência física de entrar em contato com seu calor (propriedade do fogo). Ao mesmo tempo, pode-se observar que há habilidade por parte do autor de encontrar o similar naquilo que não é (no exemplo, sensação física do amor é alinhada ao do calor do fogo) tal como já foi afirmado por Charteris-Black (2004) e discutido neste capítulo. Neste viés, os objetos de discurso são selecionados, organizados, associados e ativam, nesta relação, saberes específicos - os coletivos e os individuais - os quais ajudam a dar certo encaminhamento de sentido metafórico ao enunciado.

Assim é que também ocorre, quando o procedimento recai sobre a apresentação uma entidade com características dos seres humanos. Neste procedimento, acreditamos que experiências sensoriais (visuais, auditivas, gustativas, olfativas, táteis e espaciais) podem ser invocadas pelos discursos, por meio de seleções lexicais, de maneira que haja possibilidade de levar para próximo do outro o que, de fato, estaria distante dele em termos de concretude. Temos o processo de referenciação como orientador de sensações múltiplas, pelas quais também se constrói sentido acerca de um objeto de discurso, por meio de associações sensoriais. Fome, dor, tristeza, neste viés, são sensações que, quando despertadas, podem levar alguém a visualizar, a sentir, a compreender e a julgar dadas referências de certo modo. É nesta direção que entendemos estar a sinestesia ligada aos processos referenciais, a partir do momento em que se utilizam metáforas ontológicas.

Tais maneiras de criar e de recriar, de construir e de reconstruir objetos de discurso, inscrevem-se social e historicamente na linguagem de modo a cristalizarem-se. Nessas práticas discursivas, em que subjazem metáforas ontológicas, o homem, ser social, age não só sobre o que lhe cerca, mas também sobre si mesmo, como se houvesse a ilusão de se poder classificar, identificar e, até mesmo, julgar "as coisas do mundo" e "as coisas do homem" (Vereza, 2007, p.122). 
A partir dessa abordagem, vale-nos destacar a discussão apresentada por Vereza (2007) a respeito da noção de literalidade. A autora propõe que o sentido literal pode ser tratado como metáfora ontológica, em que há entificação (coisificação) do sentido, que o torna literal. A metáfora da literalidade consiste, assim, na atitude de conceber a palavra como algo externo ao homem. Trata-se de torná-la objeto e, consecutivamente, afastar-se dela para poder observá-la, como se este procedimento possibilitasse ao homem ver os sentidos “contidos" nas palavras ou nas formulações. Isto explicaria o fato de várias teorias linguísticas e filosóficas terem partido do pressuposto de literalização, uma vez que estariam implícitas, nesses estudos, metáforas conceptuais, como a ontológica. Essa estudiosa (op. cit., p. 122123) observa que:

Podemos conceber a metáfora da literalidade aqui tratada como uma metáfora ontológica que entifica ('coisifica', 'reifica') o sentido, tornando-o literal. Dessa forma, podemos nos referir a esse sentido (o 'sentido dessa palavra'), quantificá-lo ('esse texto não tem muito sentido'), qualificá-lo ('o sentido metafórico do termo') e identificar seus possíveis constituintes ('semas'). Até mesmo é dito que não se consegue 'ver' o sentido em um determinado texto. Somente a partir da entificação do fenômeno, podemos tratá-lo não só cientificamente, como construto teórico de ser analisado, mas também cognitivamente, como algo acessível ao pensamento ou apreensível pela 'sabedoria poética', e sociopragmaticamente, como recurso metalinguístico na interação. ${ }^{17}$

Parece-nos que a questão sobre a qual nos debruçamos inicialmente, a respeito da noção de construção de realidades discursivas, vem à tona novamente, quando se postula ser a própria atividade de reflexão e de análise um processo, no qual é necessária a entificação do fenômeno para torná-lo acessível, apreensível, compreendido e comunicado. Esta condição sociocognitiva e interacional, em que a metáfora ontológica é atuante, é indissociável dos diversos modos de referenciação, mais do que isto, podemos afirmar que um determinado fenômeno insere-se no processo referencial, na medida em que ele se torna entidade, ou melhor, um objeto de pensamento e de discurso.

Nessa direção, já que "todos os objetos de conhecimento são objetos de discurso" (Marcuschi, 2005, p. 56), a entificação de um fenômeno consiste não apenas em uma possibilidade de se falar e/ou de se pensar a respeito dele, mas também de agir sobre ele

\footnotetext{
${ }^{17}$ Grifos da autora.
} 
(qualificá-lo, quantificá-lo etc.), uma vez que, como unidades mentais e linguísticas, está condicionado a fazer parte da dinâmica do discurso e das especificidades históricas e sociais imbricadas nele. Tal posicionamento pode reforçar a ideia de a metáfora ter função social, ou mesmo, "uma dimensão pragmática" (Charteris-Black, 2006; Vereza, 2007).

\section{- Metáfora do contêiner}

Também nos interessa indicar a metáfora do contêiner (advinda dos estudos de Reddy, 1979) - também entendida como um tipo de metáfora ontológica. A partir desta metáfora, observa-se a limitação de campos de visão, como territórios, eventos, atividades etc. Parte-se do pressuposto de que essa maneira de observar o mundo deve-se à natureza dos corpos físicos que permite ao ser humano construir seu campo visual a partir de si mesmo e estabelecer limites entre ele e o outro. Há, assim, uma concepção de continente e conteúdo. Nestes casos, mais uma vez, aplica-se a questão da entificação de situações, atividades, estados.

Para Vereza (2007), essa metáfora também ajuda a explicar a noção de literalidade, uma vez que as palavras são observadas como recipientes com conteúdos (significados) específicos, os quais podem ser transferidos para outros contêineres (como no caso de palavras sinônimas). Assim, essa metáfora motiva a ideia de haver significados estáveis nas palavras. A partir disto, acreditamos que a metáfora de contêiner também esteja presente na noção de organização e de categorização, como discutiremos durante este trabalho.

\section{- Metáforas estruturais}

Além das metáforas orientacionais e ontológicas, como indicamos, existem as estruturais, em que as correspondências entre domínios caracterizam-se por serem complexas. Alguns exemplos apresentados pelos autores da TMC, nos quais evidências linguísticas marcam e disseminam conceitos metafóricos dessa ordem, são: "TEORIAS (E DISCUSSÕES) SÃO CONSTRUÇÕES”, “IDEIA É DINHEIRO”, “DISCUSSÃO É GUERRA” etc. Em relação ao último, o qual já se tornou um exemplo clássico dessa teoria, Lakoff e Johnson (1980) afirmam que a partir dessa metáfora é possível selecionar várias formulações, entre elas: "Nunca eu ganhei dele uma discussão", "Ele atacou todos os pontos 
fracos de meu argumento" ${ }^{\prime 18}$, entre outros. Nestas seleções linguísticas, existem verbos e associações de palavras já cristalizados e legitimados socialmente.

Ainda sobre esse ponto, os estudiosos afirmam que alguns indivíduos não apenas falam a respeito de DISCUSSÃO em termos de GUERRA, mas também agem conforme esse ponto de vista, ou seja, veem aqueles que contra-argumentam como oponentes, sentem-se, por vezes, vencedores ou derrotados, fazem planos e estratégias. Nestes casos, tornam-se presentes entidades do domínio-alvo DISCUSSÃO (por exemplo, os participantes da interação, seus objetivos, a relação entre eles, os recursos argumentativos) e do domínio-fonte GUERRA (os inimigos, as estratégias, os vencedores, os perdedores, entre outros). Este conjunto de correspondências entre domínios - que permite compreender, por exemplo, uma situação em que há discussão/debate em termos de guerra - foi denominado, nessa teoria, mapeamento.

É possível afirmar que, em situações de conflitos de ideias, fator característico dos discursos que circulam no campo político, como em debates políticos televisivos, não se entende haver agressão física, nem armas de fogo, mas sim uma luta discursiva - ataque, defesa, contra-ataque de argumentos. Os integrantes de determinada sociedade reconhecem essa situação social de troca linguageira e a interpreta a partir da metáfora "DISCUSSÃO É GUERRA”, sem esperar, por exemplo, um conflito armado. De acordo com Lakoff e Johnson (2003, p. 125):

Isso não quer dizer que discussões são subespécies de guerra. Argumentos e guerras são coisas diferentes - discurso verbal e conflito armado - e as ações executadas por ambos também são diferentes. Mas "discussão" é, parcialmente, estruturada, compreendida, executada e discutida em termos de guerra. ${ }^{19}$

Isso aponta para o fato de a metáfora conceptual DISCUSSÃO É GUERRA fazer parte da cultura ocidental e, de certa maneira, motivar os interlocutores a considerarem e ativarem essa noção a respeito de algumas situações sociais em que há trocas acentuadas de argumentos e, consecutivamente, orientar a compreensão, as ações e as reações dos

\footnotetext{
${ }^{18}$ Termos originais: "I've never won an argument with him"; "He attacked every weak point in my argument".

${ }^{19}$ Grifos do autor. Tradução livre de "It is not that arguments are a subspecies of war. Arguments and wars are different kinds of things - verbal discourse and armed conflict - and actions performed are different kinds of actions. But "argument" is partially structured, understood, performed, and talked about in terms of war".
} 
participantes nessas ocasiões. Nos discursos políticos, muitas pesquisas já comprovaram a presença dessa metáfora, como a de Moreno (2008), que analisou os discursos do então presidente da República Hugo Chavéz.

Esse resultado pode ser considerado um indício de estar disseminada essa construção social e cognitiva de circunstâncias que envolvem a prática política da linguagem. É possível também observar esse modo de entender ações políticas em vários outros discursos da sociedade, tal como ocorre nos jornalísticos. A este respeito, notam-se construções dessa ordem nas seguintes manchetes do jornal Folha de São Paulo: "Ausente, Lula é alvo de ataques em debate" (29/09/2009), "Lula e Alckmin partem para o ataque no primeiro debate" (09/10/2006), “Alckmin ataque e Lula reage em debate inflamado na Rede Globo $(09 / 10 / 2006){ }^{20}$

Desse modo, podemos entender que essa metáfora vem orientando uma maneira particular de conceber determinados encontros ou fenômenos políticos, ou seja, constituiu-se uma crença de um modelo de mundo da política, a qual fundamenta e orienta tanto o público quanto os participantes a relacionarem tais conceitos de guerra às características específicas da situação interacional, de modo a criarem uma imagem de si e dos outros e a estabelecerem categorias a seus objetos de discurso. Neste viés, acreditamos que isto possa ser pista indicativa que essa metáfora permeie os modelos de cognição, como os da política.

Como toda metáfora conceptual, as estruturais consistem em uma maneira de se construir realidades discursivas, mas também, como a ontológica, estão relacionadas à compreensão de conceitos de elementos abstratos, como já havíamos discutido (p.37). Isto pode ser observado no exemplo dado por Lakoff (1993) "Nossa relação atingiu um beco sem saída",21, em que AMOR foi conceitualizado em termos de VIAGEM. O estudioso afirma que essa expressão, como outras, não são selecionadas apenas para falar sobre amor, mas também para compreendê-lo.

Assim, em vários casos, há possibilidade de a metáfora permear pensamentos, ações e linguagem e, neste processo, colaborar na compreensão de conceitos abstratos, como o de amor (AMOR É VIAGEM), em que existem mapeamentos cruzados entre viajante e amante, trajeto percorrido e vida a dois, destino de viagem e destino de relação (felicidade/tristeza). Com efeito, é possível aplicar este último ponto ao processo de referenciação, quando se

\footnotetext{
${ }^{20}$ Exemplos de corpora de pesquisa de SILVA, Luciana Soares. (2008). A metáfora conceptual na construção do discurso jornalístico. Dissertação de Mestrado. São Paulo: Universidade Católica de São Paulo, PUC-SP.

21 Tradução livre de "Our relationship has hit a dead-end street".
} 
concebe que esses construtos mentais são baseados em experiências socializadas e constituídas nos discursos de modo a fazer que estes, como interação social, viabilizem um sentido público, mas não fixo, a essas entidades e motivem a ativação de objetos de discurso que pertencem, ou que foram convencionalizados a pertencerem, a esses domínios conceptuais mapeados.

Pode-se dizer que Lakoff (1993) se referiu à questão quando observou que, em um mapeamento, há uma supercategoria, em que se incluem outros níveis básicos de categoria, como no caso já indicado da metáfora O AMOR É VIAGEM, na qual relacionamento amoroso pode ser entendido como veículo e, nesta associação, estabelecer-se uma série de subcategorias pertencentes à noção de veículo (carro, trem, avião etc.). O fato é que, quando se observam discursos situados, examina-se que o locutor seleciona uma subcategoria, não outra, um item lexical que a referencie, não outro, entre inúmeras possibilidades do dizer. Tal observação novamente nos remete à ideia de um uso da linguagem e de metáfora como uma questão também de escolha.

Entende-se, logo, que a metáfora estrutural viabiliza determinado sentido de um objeto de discurso a partir de uma possível orientação dada pela apresentação de mapeamentos complexos e reforçada pela seleção de outros referentes textuais, os quais pertencem a determinados modelos de mundo - no exemplo apresentado O AMOR É VIAGEM, podem ocorrer encaminhamentos diversos, tais como: um casal pode ser construído como viajantes, a formulação "beco sem saída" pode ser selecionada e relacionada ao destino da viagem, permitindo que se crie a noção de um estado de infelicidade de uma relação conjugal. Pressupomos que tal processo de construção de sentido metafórico também implica a articulação entre uma dimensão discursiva e uma pragmática, isto é, o diálogo entre as informações organizadas em um discurso e as condições situacionais específicas deste.

Pelo exposto, entendemos que os conceitos metafóricos podem permear redes referenciais metafóricas específicas. Isto quer dizer que o encaminhamento de sentido dos objetos de discurso, que delas fazem parte, pode implicar a ativação de domínios conceptuais e seus mapeamentos por parte tanto do locutor quanto dos interlocutores. Para Lakoff e Johnson (1980), essa ativação de conceitos metafóricos ocorre de modo automático.

Para nós, o fato de esse processo ser automático, não garante que a compreensão do que se diz seja exatamente a mesma na dimensão discursiva, em razão de o sentido ser sempre situado. Nesta acepção, embora entendamos que a compreensão consista em uma construção coletiva, e que algumas metáforas estejam na coletividade de uma sociedade, também 
julgamos significativo levar em conta que a produção de sentido requer que se ativem conhecimentos gerais e locais, ajustados aos itens lexicais organizados no discurso.

\section{- Metáforas novas}

Além das metáforas convencionais, ou seja, daquelas que estruturam o sistema conceptual ordinário de nossa cultura, Lakoff e Johnson (1980, 2003) discutem a respeito daquelas que apresentam uma nova informação, um novo olhar sobre certa realidade empírica, fato também discutido por estudiosos que partiram de outras perspectivas de metáfora, como Bally (1951) e Perelman e Olbrechts-Tyteca (2002 [1958]).

Filiadas às convencionais, as metáforas novas também apresentam coerência em relação a uma cultura, ou seja, nessas novas representações, ou novos recortes, estão imbricados valores já enraizados culturalmente a respeito de certos tópicos. Ressaltamos que a interpretação de uma metáfora nova dependerá dos conhecimentos partilhados entre os falantes, pois a formulação metafórica ora pode passar despercebida, ora pode ser reconhecida e, assim, apresentar uma nova informação. ${ }^{22}$

Além das metáforas apresentadas, outro tipo que nos interessa são as universais. A este respeito, um exemplo dado por Kövecses (2005) consiste na relação estabelecida entre AFEIÇÃO e calor corporal, possivelmente, construída devido ao fato de um indivíduo ter sido, no período da infância, segurado no colo e isto ter-lhe despertado uma sensação calorosa. Tal sensação promoveu a metáfora conceptual AFEIÇÃO É CALOR e esta, por sua vez, pode resultar em formulações, como "tivemos um relacionamento caloroso", que indicam a maneira de entender essas emoções presentes nas relações humanas, como também, de construí-las discursivamente.

De acordo com Kövecses (2005, p.3), essas experiências empíricas primárias ${ }^{23}$ possibilitam metáforas universais; entretanto, tal efeito não é garantido. Elas tendem a fazer parte de várias culturas e, assim, a estarem presentes em várias línguas. A respeito da tendência desse tipo de metáfora ser universal, o autor afirma que:

\footnotetext{
${ }^{22}$ Discutimos a respeito da seleção de metáforas perante auditórios específicos no capítulo 3 .

${ }^{23}$ Para Lakoff e Johnson (1999), metáfora primária consiste na ativação de conexões sensório-motoras, pelas quais conceitualizações de experiências diárias e julgamentos são estruturados.
} 
Provavelmente ninguém ficaria surpreso ao ouvir que afeição é universalmente conceitualizada como quente, ao invés de fria. Para aprender que a metáfora "primária" não é uma escolha para nós: ela ocorre inconscientemente e automaticamente, porque isso é uma experiência universal do corpo, e a metáfora, correspondendo a essa experiência, pode bem ser universal ${ }^{24}$. Em outras palavras, experiências primárias universais produzem metáforas primárias universais.

Embora se reconheça que a ativação de uma metáfora "primária" possa ser uma maneira recorrente de compreender o que para o ser humano é abstrato, intangível (tempo, processos mentais, valores morais, instituições políticas e sociais etc.), deve-se entender que muitas delas são específicas de um contexto cultural, assim também como ocorre com os mapeamentos complexos, os quais podem se universalizar, isto é, estar presentes em várias comunidades culturais. A este respeito, Lakoff (1993) segue na mesma direção, quando afirma a existência de inúmeras metáforas que não são universais, pois as experiências variam conforme a vivência de cada um, em determinada cultura.

Por tudo que se expôs sobre a classificação de metáfora conceptual apresentada por Lakoff e Johnson (1980, 2003) - orientacional, ontológica e estrutural - ainda nos importa salientar que, de acordo com esses autores, há uma rede de significação que interliga essas metáforas de modo a fazer que exista um complexo sistema de cruzamentos metafóricos, pelo qual se pode chegar a uma metáfora complexa (estrutural), na qual estejam pressupostas outras, como as ontológicas e as orientacionais, assim, esses mapeamentos metafóricos são organizados em estruturas hierárquicas.

De maneira geral, levando-se em conta a noção de metáfora conceptual e a estendendo para um ponto de vista discursivo e interativo, o fato é que esses cruzamentos não estão separados das circunstâncias sociais imbricadas na prática discursiva e isto nos leva a afirmar que os modos de se construir discursivo-metaforicamente objetos de discurso podem-se modificar a partir das transformações ocorridas nos contextos cognitivos dos falantes após interações sociais diversas e conforme as situações específicas, nas quais eles se encontram. Seguindo nesta direção, embora a metáfora conceptual possa motivar escolhas e orientar modos de compreensão, o fato de as seleções metafóricas ocorrerem localmente e de elas interagirem tanto com outras informações postas no discurso quanto com as configurações do encontro, a partir do que dele se observa, leva-nos a crer que, na prática discursiva, elas se

\footnotetext{
${ }^{24}$ Grifo nosso.
} 
tornam elementos passíveis de serem sempre atualizados, na medida em que cada interação é única, ou seja, que a combinação dos fatores que a ela dá corpo não se repete.

Assim, de acordo com o que discutimos, se as metáforas conceptuais organizam e categorizam o mundo de algum modo, a partir de variados mapeamentos cruzados, também é possível admitir o fato de que o discurso está imbricado nesse processo de organização de categorias, em uma inter-relação funcional entre discurso e sociocognição. Tal apontamento nos distancia da noção de "modelos cognitivos idealizados" (Lakoff, 1987) e encontra embasamento na instabilidade constitutiva da atividade intersubjetiva de categorização e de recategorização de objetos de discurso.

\subsection{Categorias discursivo-sociocognitivas: organizar e dar sentido ao mundo}

Quando, no e pelo discurso, referimo-nos a uma pessoa como heroína ou a uma situação social como justa ou injusta, não necessariamente apresentamos um atributo imanente a ela, mas sim posicionamo-nos em um específico lugar social e, a partir de nossas crenças e de nossos valores, construímos discursivamente o outro de diversas maneiras, conforme as características específicas de produção. Há, pois, diversos modos de referir e de classificar que, conforme a interação instaurada, podem até conduzir a discussões, a atritos, oriundas de "rivalidades entre comunidades de mentes" (Marcuschi, 2005, p. 51).

Nesse viés, o mundo não está discretizado - estabilizado por categorias - e pronto para ser nomeado (Marcuschi, 2005, Mondada e Dubois, 2003). A discretização dar-se-á de maneira interativa e não unilateral, já que as categorizações linguísticas e sociocognitivas são influenciadas pela cultura dos falantes e, por vezes, estes negociam interativamente, em situações face a face ou a distância, os sentidos de seus objetos de discurso.

Portanto, é possível afirmar que o mundo em si é tratado pelo homem por categorias, as quais são sustentadas por instituições sociais, como se esta conduta lhe possibilitasse compreender diversos fatores que ele, de certo modo, percebeu e tenta explicar, organizandoos. Com efeito, a tendência de se considerar um mundo a priori estabelecido por categorias prontas e disponíveis de serem captadas e linguisticamente determinadas não pode se sustentar quando se tem um ser social constituído por crenças, sentimentos, cultura e orientado, durante sua vida, a fazer escolhas diversas nas relações sociais, nas quais o agir 
tem a haver com relações de poder e de força, dispositivos de controle, intencionalidades, regras sociais etc. Não se trata aqui, assim, dos elementos pertencentes ao mundo empírico, mas como estes estão inscritos, escritos/falados, construídos no discurso deste homem que assume identidades e posicionamentos.

Podemos conceber, nesse ponto, que a tendência de se observar um mundo posto em categorias fixas pode ser explicada, partindo-se da mesma motivação que se tem ao conceber a noção de sentido literal da palavra que acreditamos permear o conceito de categorias estáveis e de língua como correspondência. Retomemos a discussão de Vereza (2007, p.119), que apresenta a literalidade como metáfora conceptual:

Ao objetivar-se a linguagem para podermos dar-lhe algum sentido, nós a tornamos objeto que, como todo objeto, é caracterizado como uma forma/estrutura estável. Assim, textos e expressões são providos de um sentido permanente: eles têm significado e este, enquanto estruturador do objeto, tem de ser estável para o objeto poder existir.

Assim, a noção de sentido como entidade e das palavras ou textos como receptáculos (como discutimos às páginas 37-40, deste trabalho), nos quais são depositados os sentidos, é motivada por metáforas conceptuais (ontológica e estrutural). Tendo em vista tal abordagem, ressaltamos que essa motivação dada a partir de metáforas subjacentes pode ser aplicada, aqui, à noção de categoria/classe como contêiner, em que se classificam e se agrupam elementos, transformados em entidades, em uma relação de continente e conteúdo.

Tal afirmação também recebe, em parte, embasamento na proposta teórica apresentada por Lakoff (1993, p. 212), para quem as: “Categorias clássicas são entendidas em termos de regiões delimitadas, ou 'contêineres'. Então, algo pode estar dentro ou fora da categoria, pode ser incluído ou retirado de uma categoria. A lógica das clássicas categorias é a lógica dos contêineres" 25 .

Nesse viés, vários recipientes (categorias) demarcariam limites a partir do conceito de espacialização e organizariam o mundo de modo a estabelecer espaços fixos a determinadas referências. Algumas seleções lexicais, em nossa língua, podem indicar esse pressuposto, tais como: "nessas categorias incluem-se apenas entidades concretas"; "incluem-se na categoria

\footnotetext{
${ }^{25}$ Grifos dos autores. Tradução livre. "Classical categories are understood metaphorically in terms of bounded regions, or 'containers'. Thus, something can be in or out of a category, it can be put into a category or removed from a category. The logic of classical categories is the logic of containers".
} 
dos servidores públicos", "nessa categoria estão inseridos todos os trabalhadores", "ele acabou ficando fora dessa categoria", "foi premiada a melhor loja dentro dessa categoria", entre outras.

Como se observa, no conceito de categoria como recipiente estão implicadas noções de espacialização (dentro-fora), as quais orientam o que pode estar fora ou dentro de dada categoria e quais relações são estabelecidas entre os vários receptáculos e que ordem existe entre eles. Essa orientação espacial delineia a noção de alto-baixo ("hotel considerado de baixa categoria"); dentro-fora; frente-trás ("Tratamento de primeira categoria") etc.

É possível também identificar essa categorização, como agrupamentos em caixas, na própria organização de cidades e, até mesmo, dos objetos de uma casa. Sobre estes últimos, existem guarda-roupas, armários em que se guardam alguns tipos de alimentos, sapateiras, fruteiras, saladeiras, entre várias outras maneiras de se agrupar a partir de uma noção de classificação, divisão e limites. As teorias também são formuladas a partir de conceitos postos em categorias (como as categorias de palavras), em que são divididos, classificados.

Portanto, organizar o mundo de algum modo é prática do ser social motivado por essa ideia de espaço e de limite. A questão central a respeito de estabelecer categorias versa sobre a tendência de se considerar o conteúdo de cada recipiente como fixo e específico deste, como também, de concebê-lo como objeto externo ao olhar do homem, independente da interferência cognitiva humana, ou seja, as categorias são vistas, para muitos, como estáveis e seus conteúdos também. Nesta noção, subjazem metáforas que motivam tal concepção de maneira tão natural como se a categoria fosse algo sobre o qual se fala, existente independentemente de quem a atribuiu/criou.

À discussão apresentada, postulamos que refletir sobre algo na tentativa de dar sentido a ele implica tomá-lo como objeto de pensamento e de discurso, ou seja, está inserida uma interferência cognitiva, nesse processo, realizada na práxis social. A partir disto, são atribuídas propriedades, qualificações, classificações e, assim, modos de ver e de tratar essas entidades. Desta maneira, as categorias surgem como um procedimento de organização do mundo e recebem ajustes, pois, em encontros sociais específicos, são condicionadas por participantes sócio-históricos situados e que estão aptos a se transformarem constantemente. As palavras, então, deixam de ser continentes, cujos conteúdos são fixos e se relacionam diretamente aos elementos categorizados e, quando postas em discurso, estão intrinsecamente inseridas no processo de categorização e de recategorização. A isso, retomemos Lakoff (1977), que já afirmara ser a linguagem uma habilidade que dispõe de meios não finitos de 
formulação de enunciados, a qual não atua sozinha, mas junto a outras habilidades humanas, como afeto, imaginação, memória, capacidades motoras etc.

Ao tratar sobre os processos de categorização, Marcuschi (2005) destaca que há certa relação entre linguagem e algo externo a ela, mas não de modo rigidamente estável, indiferente às características sociais, culturais e históricas das quais fazemos parte. As categorias podem ser entendidas, neste sentido, como modelos socioculturais - e também mentais - não fixos, e sim variáveis como a própria língua, ou seja, alteram-se sincrônica e diacronicamente. Acredita-se, pois, na instabilidade da relação entre palavras e coisas. Mondada e Dubois (2003, p.22) coadunam com esse posicionamento, ao indicarem que:

As categorias utilizadas para descrever o mundo mudam, por sua vez, sincrônica e diacronicamente: quer seja em discursos comuns ou em discursos científicos, elas são múltiplas e inconstantes; são controversas antes de serem fixadas normativa e historicamente.

Se somos seres históricos e depreendemos, na práxis, um conjunto de fatores culturais que nos levam a reconhecer e a nomear certos objetos do mundo e, ao mesmo tempo, posicionamo-nos ideologicamente ${ }^{26}$, vivenciamos experiências coletivas e individuais, ocupamos lugares sociais e assumimos identidades e intencionalidades, então, postula-se que essas categorias ajustam-se a todos esses elementos e podem relativamente se estabilizarem, caso sejam legitimadas pelas regras sociais, as quais viabilizam as construções de sentido efetivadas nessas inter-relações humanas.

Outro fator que merece nossa atenção corresponde à condição humana de observar um objeto a partir de um ponto de referência, que é ele mesmo, já que o homem não pode se afastar de si, fisicamente e psicologicamente, e ocupar o lugar do outro de modo a experimentar sua visão sobre os fatos. Tal afirmação pode ser relacionada também aos pressupostos de Lakoff e Johnson $(1980,2003)$ no que diz respeito à compreensão ser fundamentada a partir da experiência corpórea; entretanto, julgamos pertinente estender essa noção de produção do conhecimento e compreensão às vivências sociais, ou seja, às experiências, coletivas e individuais, efetivadas em situações diversas de interação. Tendo em

\footnotetext{
${ }^{26}$ Neste trabalho, assumimos o conceito de ideologia utilizado por Charteris-Black (2011 [2005]) e por van Dijk (2003, 2004a, 2004b). De modo geral, ideologia consiste de um conjunto de ideias e de crenças compartilhado por um grupo social, que cria representações organizadas e sistemáticas sobre o mundo. A este respeito, discutimos com mais detalhes no capítulo 2.
} 
vista este posicionamento, entendemos que os ajustes e as negociações feitos em determinadas situações, bem marcados em situações face a face, justificam-se, também, por essa tentativa de se chegar a um lugar comum e isto também tem caráter argumentativo, quando se quer fazer que o outro entenda e aceite o sentido proposto de um objeto de discurso a partir de um ângulo e, assim, levando-o agir de um determinado modo.

Aproximamos essas afirmações ao pressuposto de Teubert (2010), para quem o sentido que damos ao mundo não existe fora da prática social. Neste posicionamento, não interpretamos o (extra)mental para/por nós mesmos, em uma atividade especificamente individual, mas sim levamos em conta as interpretações já feitas por outro(s) - mesmo que este(s) seja(m) uma imagem mental. O autor (op. cit.) ainda ressalta que dar sentidos as nossas experiências ou às de outras(os) pessoas/grupos implica refletir sobre elas e, concomitante a isto, partilhar desses sentidos socialmente. Esta atividade social e interativa dá-se no e pelo discurso e permite que diversas construções discursivas da realidade sejam trocadas e compartilhadas em uma sociedade.

Tal fato reforça o caráter dinâmico e dialógico das práticas discursivas e da ação do homem sobre o mundo a partir e por meio delas. Assim, acontecimentos históricos e sociais, nações/grupos etc. são construídos a partir de um processo sociocognitivo em que o discurso cumpre papel significativo, de tal modo que sem ele "nossa vida tornar-se-ia desprovida de sentido" (TEUBERT, 2010, p. 2).

Nesse viés, também as relações entre o homem e o mundo são construídas pelas linguagens - verbal e não verbal - e se ajustam a fatores externos a elas. Em situações discursivas, interpretamos, (re)construímos e (re)categorizamos o mundo empírico também pelo diálogo estabelecido entre nossos discursos e os outros que circulam na sociedade, situados em específicas condições de produção e posicionados ideologicamente. Tais especificidades inerentes à produção do discurso reforça a ideia de ser este uma forma de ação e de interação social.

Dessa maneira, a produção de sentidos vai além da identificação de informações, ela se caracteriza por ser uma ação dinâmica, em que coprodutores inserem-se em práticas sociais diversas, envolvidos por fatores cognitivos, culturais e históricos. Podemos afirmar, assim, que o sentido não está, unicamente, no leitor, no texto ou no autor, mas sim na relação estabelecida entre todos estes e suas atividades sociais. Portanto, um interlocutor não entra em contato apenas com um discurso, mas também com o que está além deste, conforme afirma Marcuschi (2008, p.233): "para se compreender bem um texto, tem-se que sair dele, pois o 
texto sempre monitora seu leitor para além de si próprio e este é um aspecto notável quanto à produção de sentido".

Distancia-se, mais uma vez, da ideia de haver dicotomia entre sentido literal e figurado, de palavras com conteúdos fixos, já que a língua funciona além dela mesma, e o sentido é um efeito de tal dimensão. Também é Marcuschi (2008, p. 234) que afirma:

Assim, não se pode vincular o sentido literal de uma forma automática a palavras, pois elas podem ter vários sentidos literais. O sentido é um efeito do funcionamento da língua e não uma simples propriedade imanente ao item lexical como tal.

Tal afirmação remonta ao que já discutimos (à página 28) sobre as teorias, nas quais a metáfora foi, e ainda é, observada por muitos, como um fenômeno linguístico especificamente, por se examinar a língua independente das interações sociais e do componente cognitivo e se debruçar sobre a dicotomia literal vs. figurado (não deixando de ser também um conceito baseado na noção de limites).

Assim é que o sentido não é algo dado, exclusivamente, no enunciado ou na seleção de um item lexical; ele está relacionado à dimensão também dinâmica dos processos de referenciação. Nesta acepção, Marcuschi (2007) segue afirmando que há uma relação bem estreita entre referência e inferência, uma vez que a explicitude consiste de um dizer que é interpretável. Corresponde, portanto, à atividade de oferecer condições aos interlocutores para que eles tenham acesso às informações, postas ou inferíveis no processamento discursivo, e as compreendam por meio da ativação de conhecimentos.

Para o autor, o sentido do que se diz relaciona-se a quem diz e, também, ao que o locutor está fazendo no momento da interação. Tais lacunas supostamente deixadas, por vezes, na linguagem, são preenchidas nesse processo de inferência, como ocorre nos exemplos dados por esse estudioso (op. cit., p. 67): “A madame saiu à rua com seu cachorro", “O policial saiu à rua com seu cachorro". Nestas formulações, as raças dos cachorros não são postas, mas, provavelmente, podem ser inferidas (Madame, Poddle; policial, Pastor Alemão) por se conhecer e ativar conhecimentos contextuais, pelos quais é possível relacionar objetos de discurso, categorias relativamente estabilizadas e modelos mentais de mundo. 
Dessa maneira, temos que a participação do outro é indissociável do processo de construção de sentido de objetos de discurso e depende das condições específicas de produção. Roncarati (2010, p. 34) coaduna-se com tais afirmações:

Como proposta de sentido, o texto só se completa com a participação do interlocutor. E, a depender de nossas condições socioculturais, de nossos propósitos de leitura e mesmo de nosso estado mental e emotivo, podemos chegar a compreender um mesmo texto de maneira muito diversa.

Assim, os sentidos passam por um processo de construção e de desconstrução e, também, de negociação e de renegociação. Formulações já enunciadas, por sua vez, podem ser repetidas e inseridas em novos contextos sócio-históricos, ideológicos e linguísticos; os enunciados recuperados são sempre atualizados e podem ser aceitos, negados ou ironizados, num diálogo entre o novo e o já-dito.

Aproximamos esses fatores à perspectiva de O’Brien (2010) - da psicologia social e do interacionismo simbólico - o qual retrata os seres humanos como cocriadores ativos de suas experiências individual e coletiva e trata o contexto situacional como parte deste processo. Nesta perspectiva, reagimos sobre o mundo conforme a maneira como definimos ou percebemos determinadas situações. A reação depende, especificamente, do momento histórico-social e de como somos inclinados ou orientados a ver o que está ao nosso redor.

Sobre esse último ponto, o qual julgamos possível denominar orientação de olhares, as crenças e os valores advindos de um contexto cultural delineiam o que pode ser visto como real ou irreal, como certo ou errado etc. Assim, eles podem ser considerados como regras sociais - não necessariamente baseadas na lógica ou em percepções sensoriais - que nos orientam a darmos sentido a nossas experiências e partilharmo-las uns com os outros. Lembremos que, para O’Brien (2010), essa atividade interacional de darmos sentido ao mundo é sempre situada.

Nas interações sociais, assim, há um conjunto de crenças e de valores construídos socialmente, que direcionam um olhar específico sobre o mundo e que está presente como fator significativo na construção de sentido dessa realidade empírica - atividade interativa constitutiva do discurso e também constituída por ele. 
Do mesmo modo, pode-se afirmar que os indivíduos categorizam e recategorizam o mundo em uma dimensão histórica e social de maneira dinâmica. Neste viés, retomemos o postulado de que eles, para lidar com o extramental, constroem diversas categorias, as quais só são efetivadas caso os outros integrantes do grupo estejam de acordo. Isto ocorre em áreas diversas como na da ciência, em que só serão classificadas desse modo se determinada comunidade científica assim concordar. Há necessidade, pois, de um dispositivo social para autorizar certas categorizações e recategorizações de objetos de discurso.

Ao mesmo tempo, a categorização consiste, várias vezes, de uma decisão, uma escolha de um indivíduo que, por estar situado em um contexto interacional, ativa um modelo cognitivo do encontro e, assim, leva em conta as regras estabelecidas. Nestes casos, a construção do referente textual é efetivada local e interativamente, e também não é dada a partir de uma realidade independente (Mondada, 2005a, 2005b; Mondada e Dubois, 2003), já que, como mencionamos, a língua não pode ser apartada desses indivíduos, inseridos em situações sociais, que desenvolvem percepções e compreensões em constante transformação a partir da mobilização de conhecimentos linguísticos, discursivos e episódicos. Tais fatores nos permitem afirmar que o processo de referenciação também é adaptativo, como o discurso o é.

De modo geral, criar categorias discursivas, ou distinguir um objeto de discurso de outro, leva-nos a construir imagens do mundo e de nós mesmos. Esse processo de (re)categorização, especificamente humano, tornou-se tema de diversas áreas do conhecimento - como no campo do discurso (Mondada, 2001, 2002, 2005a, 2005b; Marcuschi, 2001a, 2002a, 2004, 2005), da psicologia social (O’Brien, 2010), das ciências cognitivas (Lakoff e Johnson, 1980) etc. A partir dele, torna-se possível estudar e compreender comportamentos, contextos cultural-históricos e mentais, organizações textuais e discursos específicos, conforme entendemos observar pronunciamentos feitos por um chefe de Estado, foco deste trabalho.

Com base nessas reflexões, a respeito da (re)categorização, da metáfora e da interação, propomos estabelecer um diálogo entre tal discussão e os estudos sobre os modelos mentais de evento de van Dijk (2007, 2009, 2010). Entendemos que essa junção teórica nos ajudará a compreender melhor a estabilidade relativa das categorias discursivo-sociocognitivas e a função da metáfora nesses processos de construção, cuja dimensão social e interativa, como já posto, é de fundamental importância. 


\subsubsection{Modelos cognitivos de situações interacionais e práticas discursivas}

Os seres sociais participam, leem/conversam, assistem a inúmeros encontros socialmente institucionalizados. Nessas experiências, constituem representações mentais dessas atividades, que influenciam na elaboração e na interpretação de discursos, na medida em que há, geralmente, adaptação por parte dos participantes às principais características da situação discursiva, onde se encontram: o ambiente (tempo, lugar), os participantes (papéis sociais, identidades de grupo e relações entre eles) e as ações. A isto van Dijk (2007, 2009, 2010) denominou modelos mentais de eventos.

De acordo com o autor, os modelos de eventos influenciam nas escolhas linguísticas e, consecutivamente, nas estratégias discursivas, como: expressões dêiticas, formulações de cortesia, estratégias retóricas e argumentativas etc. $\mathrm{Na}$ elaboração do discurso, em uma específica situação social, caso um dos participantes não leve em conta o modelo cognitivo em questão, possivelmente, ocorrerão conflitos ou problemas de comunicação, já que se criam certas expectativas em relação às atitudes discursivas de cada um.

Concomitante à ativação de um modelo de evento, o locutor aciona um modelo mental relacionado a si próprio, a sua experiência pessoal (memória episódica), a seu repertório enciclopédico. Desta maneira, na elaboração do discurso, há a ativação de modelos mentais macro e micro. A respeito disto, observemos a seguinte tabela (VAN DIJK, 2007, p. 10):

\begin{tabular}{|c|c|}
\hline Micro Cenário & Macro Cenário \\
\hline Hora/tempo da interação & Período da interação (semana, mês, ano) \\
\hline Localização: endereço & Espaço (cidade, país) \\
\hline Participantes: pessoas & Participantes: grupos, instituições e organizações. \\
\hline $\begin{array}{l}\text { Identidade: por exemplo, professor } \\
\text { - } \quad \text { Papéis: ensinar } \\
\text { - } \quad \text { Relações: poder pessoal } \\
\text { - } \quad \text { Objetivos pessoais } \\
\text { - } \\
\end{array}$ & 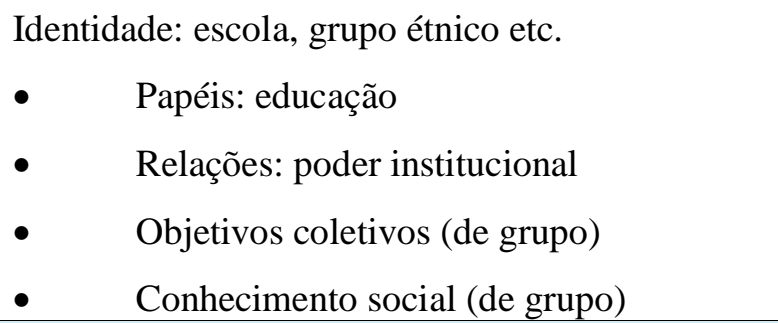 \\
\hline Ações do indivíduo & Ações coletivas (institucionais, de grupo) \\
\hline
\end{tabular}

Tab. 01. Modelo Mental de Evento: Cenários Macro e Micro 
Nessa tabela, o autor indica que, em uma situação discursiva, há a ativação simultânea de dois cenários mentais. No primeiro, à esquerda, encontram-se informações individuais, as quais o produtor de texto ativa a partir de uma visão microestrutural de si: quem eu sou, quais são meus objetivos, qual é minha profissão/papel social no momento enunciativo etc. No segundo, à direita, mostram-se características de um cenário mais abrangente, especificamente, coletivo e organizado socialmente, em que o ser, em sua individualidade, percebe-se inserido em um espaço social mais amplo, onde há regras para cumprir, autorizadas por instituições, ideologias (crenças, valores) de grupo, entre outros.

Assim também, o ambiente mental de uma interação social insere-se em um aqui e um agora - relação tempo e espaço entendida em um sentido amplo, em que se considera a localização espaço-temporal micro inserida em uma mais ampla (macro). Em outras palavras, o locutor ativa desde conhecimentos sobre a rua e o bairro onde ele está (conhecimento micro), até a respeito da cidade e do país (conhecimento macro), relacionando essas informações ao horário da atividade discursiva, ao dia da semana, ao mês e ao ano. van Dijk (2007, 2009, 2010) afirma que as informações globais (macro) podem ser mais acessíveis. Lembrar do ano e do mês, no momento da escrita/da fala, é, por exemplo, mais frequente do que do dia e da hora; informações que, por vezes, precisam ser consultadas.

Ainda de acordo com esse estudioso, ao falar ou ao escrever, e conforme o modelo do evento ativado, o produtor de textos não só constrói mentalmente uma imagem de si, como também prevê as de seus interlocutores (grupos ou indivíduos). Nota-se que não só a construção do modelo contextual é significativa para tomada de decisões, mas também o lugar que o locutor assume quando se insere nesse contexto é relevante para determinados posicionamentos.

Dessa maneira, nos discursos, é possível que se apresentem marcas linguísticas de imagens mentais e da relação construída entre elas. Nestas práticas, ocorre que, primeiramente, o produtor de texto posiciona-se como membro de uma organização (um determinado jornal, uma escola, uma instância política) e de um grupo de profissionais (os jornalistas, os professores, os políticos) e, a partir deste procedimento, direciona-se ao seu interlocutor, no e pelo discurso, conforme as regras partilhadas e inter-relacionadas.

Sobre esse último ponto, sobre as imagens construídas dos interlocutores, van Dijk (2007, 2009, 2010) ressalta que, em certos discursos, como o jornalístico, a imagem do leitor remete a uma coletividade, que é orientada por modelos socioculturais ativados a respeito desse grupo. Pode-se afirmar que assim também ocorre nos discursos políticos, os quais se 
inserem em práticas sociais específicas, nas quais o político pressupõe as características daqueles para quem se dirige e, consecutivamente, age discursivamente de modo considerado adequado em termos de seleção de informações, de formulações linguísticas e de organização discursiva.

De maneira geral, podemos observar que há estreita relação entre modelos cognitivos de eventos sociais e discurso. Fato é que o procedimento discursivo está ligado à maneira como um participante entende e constrói a situação interacional, na qual ele se encontra. Assim, entendemos que, nas seleções lexicais, como as referenciais, estão imbricadas essas representações mentais de situações específicas.

\subsubsection{Relação entre modelos cognitivos de eventos sociais, processos referenciais e categorizações}

Pelo exposto sobre modelos cognitivos de eventos sociais, a partir dos estudos de van Dijk (2007, 2009, 2010), julgamos necessário discutir alguns pontos, associando-os aos objetivos deste trabalho e ao nosso corpus.

Temos que os modelos de evento estão imbricados nos processos de referenciação. Nesta acepção, a maneira como um indivíduo se vê, entende uma circunstância social e se relaciona com ela orienta a constituição de redes referenciais específicas. Além do mais, a imagem da coletividade pode ser substituída, em termos de relevância, pela noção que se tem a respeito de um dos participantes da interação, em razão de ele ser reconhecido como uma figura importante, sobre quem o discurso deve agir. Assim é que a presença de uma determinada pessoa, ou de um participante indireto, pode influenciar de maneira significativa no encaminhamento discursivo.

Outro ponto que julgamos necessário destacar a respeito dos modelos de eventos refere-se à construção não fixa deles, ou seja, acreditamos que eles também variam sincrônica e diacronicamente devido a alguns fatores, como: as mudanças político-econômicas e socioculturais (valores, crenças), que influenciam diretamente a relação entre os participantes de uma específica situação social, as novas tecnologias (internet, televisão etc.) e necessidades sociais e comerciais. Um exemplo disto consiste no atual modelo de sala de aula - relação professor e aluno, aulas a distância, por vídeo conferência etc. - que difere de modo significativo daquele construído há algumas décadas. Assim, os modelos macro e micro (Cf. tabela 01) alteraram-se e, neste quadro, há possibilidade de construções de diferentes modelos 
de eventos efetivadas por pessoas de gerações ou de regiões distantes. Estas diferentes construções podem acarretar em divergências nas inter-relações humanas por conta de discordâncias a respeito do modo de entender os lugares sociais.

Em situações em que os discursos políticos circulam, também podem ocorrer (re)construções de modelos de eventos. Mais recentemente, há assembleias legislativas abertas ao público, que podem ser gravadas e veiculadas pela mídia (como internet), reuniões parlamentares televisionadas, criação de alianças internacionais, participação ativa de países emergentes em encontros internacionais, entre outros. Estas novas especificidades podem estar presentes nos modelos mentais, a respeito da situação interacional, constituídos pelos políticos.

Assim é que as (re) construções de modelos de eventos influenciam na (re)categorização de objetos de discurso, pois são procedimentos linguístico-discursivos estreitamente relacionados ao papel que um participante assume no momento da enunciação (como se vê) e à maneira como ele lê e interpreta a interação; novamente, pois, remetemos à constituição de modelos macro e micro como fator importantíssimo no processo referencial do discurso.

Além do mais, entende-se que os modelos de evento podem ser construídos de maneira associativa a outros modelos de mundo preexistentes. Com efeito, ainda, em muitos dos modelos cognitivos da vida política, e nas circunstâncias sociais que a envolvem, há metáforas subjacentes que os sustentam. Assim, é possível entender ações políticas em termos de construção, as posições partidárias como contêineres, as diferenças e os papéis sociais a partir da noção de espaço, entre outras possibilidades, tendo como base conceitos metafóricos, presentes nesses modelos de eventos, que motivam referenciações específicas de caráter também argumentativo. As categorias discursivas selecionadas servem, pois, como pistas da tentativa do locutor de buscar adequações para que seu dizer esteja relacionado à situação e aos referentes postos em discurso.

Nesse sentido, como discutimos, o modelo cognitivo de situação de guerra constituído não apenas pela experiência física, mas também pela atividade discursiva caracterizada por ser dialógica e interativa - foi utilizado, por exemplo, nas construções de modelos pertinentes aos espaços de discussão política, como debate político, campanha eleitoral etc. Essa representação mental metafórica, social e discursivamente constituída, influencia na ação e na reação discursiva dos que participam do evento direta ou indiretamente, enquanto que os formuladores do discurso costumam categorizar seus 
adversários de maneira negativa, e os leitores já esperam esse procedimento, ou seja, eles agem como se estivessem situados em um espaço com limites demarcados. Portanto, observase que a mudança e a construção de contextos sociais cognitivos implicam especificidades de seleção do léxico, da organização do discurso e, até mesmo, da estruturação de categorias cognitivas.

Ainda a respeito dessas categorias, ao retomarmos o postulado sobre a metáfora, como processo sociocognitivo-discursivo, imbricado na maneira de compreender e de discursivizar o mundo, organizando-o e dando sentido a ele, podemos afirmar que muitas delas (dessas categorias) são construídas de maneira metafórica ou, mesmo, propor que, no processo de (re)categorização apresentado na rede referencial, subjaz o conceito de contêiner.

A respeito da discussão sobre (re)categorização discursiva e dos apontamentos dos itens 1.3.1. e 1.3.1.1, entendemos ser possível apresentar a síntese a seguir:

1) a atividade discursiva de categorizar pessoas, objetos etc. é situada e relaciona-se à construção de um modelo cognitivo micro e de um macro da situação social; no contexto escolar, algumas formulações são privilegiadas a partir do que se entende sobre esse encontro ou de acordo com intencionalidades diversas, tais como: professor, tutor, mestre, orientador, educador, um nome próprio etc.; no campo político, também são variáveis as seleções: presidente da República, representante de uma nação/grupo, chefe de Estado, parceiro político, entre outros.);

2) as categorias selecionadas em um discurso podem ser pistas dos modelos mentais micro e macro construídos pelo locutor;

3) se existem possibilidades de (re)construções de modelos de eventos, isso nos faz compreender, em parte, o caráter mais ou menos instável das categorizações discursivas e, também, permite reafirmar que a língua não é representação da realidade empírica;

4) se, por um lado, a atividade de categorizar o mundo consiste de uma maneira de organizá-lo, por outro, os modelos de eventos correspondem ao modo como os indivíduos compreendem a organização de uma sociedade e, a partir disto, agem e reagem sobre ela, mantendo ou modificando-a cognitiva e discursivamente;

5) os modelos mentais da vida social são convencionalizados e também podem ser licenciados por metáforas conceptuais subjacentes, como o que aconteceu, em 
algum momento, entre o conceito de guerra/de teatro e o de situação social de debate político; tal como pode ocorrer em seus ajustes e em suas transformações;

6) as criações e as compreensões de modelos novos de eventos podem ser orientadas por metáforas subjacentes, principalmente, se levarmos em conta o mundo atual caracterizado, cada vez mais, por ser dinâmico e interativo por conta da globalização e do aprimoramento das tecnologias; a metáfora pode ajudar no processo de compreensão e de construção de sentido dessas situações sociais em processo de mudança, como ocorre com a compreensão das interações virtuais ou via aparelho móvel, em que a noção de espaço e de limite (aproximação e distanciamento), e até mesmo a de presença física, por vezes, é transformada.

A respeito das duas últimas considerações, há um processo supostamente natural e também adaptativo, quando um modelo cognitivo de uma situação social é ativado e interrelacionado a outras situações da vida e isto requer ajustes entre domínios diferentes ou não. Como também, conforme Mondada e Dubois (2003, p. 25), "quando um contexto discursivo é enquadrado (Goffman, 1974), as categorias podem ser avaliadas e transformadas, juntando diferentes domínios, como nas metáforas, recategorizações e metalepses". Assim, é possível que haja variação categorial quando uma situação é vista sob diferentes ângulos, ou mesmo, quando há relação entre modelos diferentes, que implicam categorizações diversas dos participantes, dos fatos e do próprio encontro. Tal dimensão contextual emerge na referenciação e na construção e na reconstrução de categorias de sentido metafórico, ou mesmo de caráter metafórico - quando entendemos haver metáforas subjacentes no processo de categorização dado pela referenciação - sobre as quais passamos a discorrer.

\subsubsection{Categorização e recategorização metafórica}

Como discutimos, categorizar discursivamente o mundo, de modo metafórico ou não, consiste de uma tentativa de compreendê-lo, de organizá-lo e de dar sentido a ele de maneira dinâmica, interativa e dialógica. Nesta ação discursiva, acionam-se fatores linguísticodiscursivos, sociocognitivos e interacionais, os quais possibilitam as diversas construções de objetos de discurso. Assim, ao construí-los, o locutor não está apartado de suas crenças e de seus valores, nem tão pouco fora das regras sociais, que envolvem certas situações 
discursivas. Há um processo de adequação ao contexto cognitivo ativado, o qual pode ser constituído a partir de uma relação entre domínios.

Quanto às categorias metafóricas, algumas pesquisas, como a de Glucksberg (2008), observam o sentido metafórico estabelecido a partir da relação de dois referentes textuais. $\mathrm{O}$ autor pressupõe haver referência dupla, quando pelo menos dois objetos de discurso são mencionados e afirma que, em metáforas cuja formulação consiste de "X é Y", ao primeiro (tópico), dá-se a categoria e algumas propriedades, por vezes estereotipadas, do segundo (veículo), enquanto outras são desprezadas.

Nessa perspectiva, uma categoria metafórica constitui-se a partir de uma concentração semântica, em que $\mathrm{X}$ é construído por meio de apenas alguns traços de $\mathrm{Y}$, reconhecidos socialmente, relacionando-os como coexistentes. É o que ocorre com a metáfora de personificação, pois a concretude dada ao que era abstrato constrói-se não por se levar em conta toda complexidade do ser humano, mas sim por evidenciar algumas características dele julgadas relevantes para se construir, concomitantemente, um segundo objeto de discurso ${ }^{27}$.

Já Mondada e Dubois (2003) consideram que objetos de discurso vão se refinando durante o processo discursivo, ou seja, modificações são operadas de modo a fazer que a primeira categoria posta sobre o objeto de discurso receba alterações a partir do momento que este é incluído em outra, em um processo de recategorização. O sentido do objeto de discurso concorre com as categorias selecionadas e se efetiva a partir do contraste com aquelas que as precederam. A partir disto, Apothéloz e Reichler-Béguelin (1995) afirmam que as recategorizações metafóricas manifestam-se por meio de seleções lexicais, que explicitam predicados de sentido metafórico a partir da correferencialidade entre os termos, por meio de uma anáfora direta, de maneira a possibilitar orientação argumentativa. Tal abordagem também pode ser observada nos estudos de Koch (2005).

Além do exposto, tem-se que a observação da categorização metafórica na dinâmica discursiva requer mais do que classificações e análise de seu funcionamento em uma específica formulação. Para o exame dos processos de referenciação, torna-se necessário, por vezes, ir além do exame de retomadas referenciais feitas a partir de expressões metafóricas. Para Leite (2007), o caráter metafórico de um objeto de discurso nem sempre está marcado na unidade linguística utilizada para apresentá-lo, mas sim na relação estabelecida com outras

\footnotetext{
${ }^{27}$ Embora não nos debrucemos sobre a questão da metonímia, entendemos que, no processo de categorização metafórica, também subjaz um processo metonímico. Do efeito de coexistência entre dois objetos de discurso, a continuidade é estabelecida, já que, em termos discursivos, não se utiliza o objeto veículo em sua totalidade, mas sim se destaca uma parte/propriedade dele que será atribuída a outro.
} 
expressões referenciais. Tal posição indica ser necessário não se debruçar apenas sobre a identificação de uma única expressão recategorizadora, mas sim observar o efeito metafórico a partir de outras ocorrências linguísticas.

Além disso, parece-nos que o postulado de os objetos de discurso serem construídos na relação estabelecida entre eles e as outras formulações selecionadas pode ser estendido ao pressuposto de que todo discurso é situado e que os sentidos correspondem a efeitos, os quais, para serem alcançados, mobilizam-se diversos conhecimentos de língua e de mundo. Ir além da língua, assim, pode ser um caminho para se observar a questão da (re) categorização metafórica, muitas vezes, efetivada por anáforas indiretas, ou seja, pela ativação de um componente cognitivo relacionado à interação, tanto por parte de quem elabora o discurso, quanto de quem interage com ele.

\subsubsection{Processos de categorização metafórica: inter-relação funcional entre discurso, cognição e práxis}

Em uma pesquisa realizada por Lima (2007), identificou-se que muitas categorizações metafóricas não são manifestadas, especificamente, por meio de anáforas correferenciais, nem mesmo a partir das formulações linguísticas. Destacou-se que o sentido metafórico de um objeto de discurso, que não apresenta antecedente direto no texto, pode ser construído em uma dimensão cognitivo-social. Levando-se em conta tal pesquisa, parece-nos coerente dizer que a criação de categorias metafóricas também está relacionada aos vários modelos de eventos coproduzidos em uma sociedade.

Sobre esse ponto, interessa-nos retomar a afirmação de Marcuschi (2007), com que Koch $(2005,2008$ a) se coaduna, apresentada à página 51 deste trabalho, a respeito da estreita relação entre referência e inferência, na medida em que a noção de explicitude caracteriza-se por corresponder a uma atividade de oferecer subsídios ao outro, pelos quais se torna o dizer interpretável. Os conhecimentos prévios permitem preencher certas lacunas deixadas no enunciado pelo locutor e, assim, possibilitam que o interlocutor faça associações e atribua um

sentido metafórico ou não ao objeto de discurso. Tal procedimento insere-se na maneira como os participantes relacionam elementos linguísticos e fatores pragmáticos no momento da enunciação.

Seguindo nessa direção, Koch (2005, 2008a) assinala que a construção e a reconstrução de objetos de discurso efetivam-se não apenas por meio das marcas linguísticas 
- e das possíveis inferências atribuídas a partir dessas seleções, as quais se dão pelos conhecimentos linguísticos, enciclopédicos, culturais etc. de cada indivíduo - mas também pelos saberes, opiniões e juízos partilhados entre os participantes da interação. Por conta disto, a interpretação e a reação do interlocutor podem ou não ser as esperadas pelo locutor. Como também, parece possível dizer que algumas nomeações de referentes textuais só estabelecem sentido no cotexto, no contexto sociocognitivo e na situação interacional, conforme buscamos examinar no capítulo destinado às análises.

Assim, mais uma vez, afirma-se que fatores contextuais e cotextuais são significativos para a questão da referência. A respeito disto, cabe-nos também considerar o que muitos estudiosos já afirmaram a respeito dos pronomes e seu papel nos processos referenciais. No caso dos pessoais, lembremos de Benveniste (1976, p.278) que define o pronome de primeira pessoa em termos de locução, o que ocorre também com o "nós" e "a gente", conforme pesquisas, como de Silva (2004) que evidencia o papel multirrefenciador dessas seleções linguísticas e a importância de dados contextuais e cotextuais para sua identificação referencial. Tal fato também ocorre com pronomes demonstrativos, os quais exigem, para sua interpretação, uma ancoragem com outras informações postas e organizadas no discurso.

Isso não pressupõe a inexistência de relações anafóricas que orientam a construção de objetos de discurso com sentido metafórico, nem indica que não exista um encaminhamento na organização do enunciado. O que se entende é que a metáfora, em discursos, estrutura a categorização de objetos de discurso, de modo não tão rigidamente marcado na formulação linguística referencial, mas sim de maneira que sua compreensão se dá, como foi inicialmente mencionado neste trabalho, a partir de seu lócus, que consiste de uma inter-relação funcional entre discurso, cognição e práxis, conforme buscamos comprovar

Uma vez que a referenciação é compreendida, levando-se em conta esse complexo sistema que a envolve, entendemos que a organização do discurso relacionada ao contexto situacional imediato dá condições para que sejam construídos mundos metafóricos. Estes, portanto, consistem do resultado do entrelace de saberes diversos, que são mobilizados de modo estratégico, item que passamos a discutir.

\subsection{Estratégias de referenciação}

Conforme Koch (2005, 2008a, 2008b), na memória discursiva, há algumas operações básicas implicadas nas estratégias de referenciação: ativação, reativação e desativação de 
objetos de discurso. Neste processo referencial, ocorre a repetição constante dessas estratégias de maneira, por um lado, a estabilizar o modelo textual e, de outro, a reelaborá-lo e modificálo por meio de novas referenciações (Schwarz, 2000). Essas estratégias colaboram para manter os referentes no fluxo discursivo e, consecutivamente, criar novas categorizações e avaliações a respeito desses referentes textuais.

Do mesmo modo, as palavras e as expressões estabelecem relações referenciais específicas e interativas dentro do processo discursivo. Propõe-se que, fora desse processo, nelas, está implicada uma multirreferencialidade. Isto quer dizer que a função referencial poderá ser delimitada/especificada na prática discursiva, no momento em que um objeto de discurso é posto em foco e interage com as informações apresentadas e/ou com as condições específicas de produção. Tal afirmação leva em conta que a seleção de formulações linguísticas na função referencial pode ser provisória, adaptativa, ou mesmo, criativa. Neste sentido, acreditamos que a observação da metáfora como estratégia referencial colabora para entendermos esse caráter multiferrencial das palavras, assim como, sua "plasticidade" 28.

Ainda em relação aos processos de referenciação, o objeto de discurso, uma vez ativado, pode ser retomado (processo anafórico) de modo a constituir uma cadeia/rede referencial. As relações fóricas (anafóricas e catafóricas) e dêiticas existentes no discurso são estabelecidas por meio de mecanismos de retomada e de remissão. $\mathrm{Na}$ atividade de retomar, há continuidade no núcleo referencial, ou seja, uma relação direta com um objeto já ativado. Para Roncarati (2010), a constituição desses elos fóricos também leva em conta os recursos disponíveis na língua. Para a autora, há uma variedade constitutiva de cadeias referenciais manifestadas por meio de instabilidades inerentes a alguns níveis: categorial, uso de expressões referenciais e de predicações atributivas; tipológico, em que pode haver cadeia linear, múltipla ou multirreferencial, híbrida; cognitivo e pragmático, quando se considera adequação das estratégias de referenciação, conforme as finalidades do encontro social e as funcionalidades de uso da língua.

Cabe lembrar que o objeto de discurso pode ser desativado, "passando então a ocupar uma posição marginal" (KOCH, 2008a, p.102); a qualquer momento, sua reativação pode ocorrer. A retomada anafórica pode-se dar pela seleção de nomes próprios, expressões nominais, descrições, pronomes, encapsulamentos, categorizações metaenunciativas, articuladores metadiscursivos.

\footnotetext{
${ }^{28}$ Termo utilizado por Guimarães (1999) para afirmar que as palavras podem ganhar sentidos diversos na prática discursiva.
} 
No caso das expressões nominais, a retomada anafórica efetiva-se por meio da repetição do nome-núcleo, total ou parcial, da seleção de uma sinonímia (hiperônimos e hipônimos), por nomes genéricos e por descrições. Tendo em vista a construção de sentido, a seleção nominal, ou seja, a escolha do núcleo das formas nominais anafóricas cumpre significativo papel, especialmente quando há retomada por repetição total ou parcial, já que, quando se repete um termo, há a possibilidade de enfatizar determinadas características dadas a um objeto de discurso.

Ainda sobre esse ponto, também a anáfora por sinonímia é significativa para os possíveis sentidos construídos nos discursos. Nesse tipo de seleção, estão implicados as características do gênero discursivo, as condições específicas de produção, a variedade de opções de palavras sinonímicas disponíveis em um sistema linguístico, a variação linguística (regional, por exemplo), a individualidade, ou estilo, do locutor e, como já discutimos a partir de van Dijk (2007, 2009, 2010), o modelo mental criado sobre a situação interacional.

Nesse viés, conforme o repertório linguístico do locutor, o gênero discursivo e as características do momento enunciativo e do modelo criado a respeito dele, é possível apresentar algumas seleções nominais em vez de outras. A respeito de escolhas linguísticas, Koch (2008b) afirma que a partir dos entornos específicos de cada produção discursiva, alguns termos são mais apropriados e frequentes. Para a autora, palavras como casa, domicílio, moradia, residência etc., embora designem "lugar onde se mora", produzem efeitos de sentido diferentes e são selecionadas em contextos distintos.

As retomadas correferenciais por hiperonímias/hiponímias, por nomes genéricos e por descrições nominais são também relevantes para a construção de sentido. A partir delas, há (re)categorizações, em maior ou menor grau, do objeto de discurso. Ainda de acordo com Koch (2008b), o hiperônimo utilizado para a retomada de um objeto de discurso introduzido por um hipônimo consiste de uma estratégia que "assegura um mínimo de estabilidade informacional" (op. cit., p. 266), visto que esse tipo de anáfora contém traços semânticos os quais se ajustam ao seu antecedente de modo a possibilitar uma recategorização, em menor grau, do referente textual. Tal procedimento linguístico pode também ser visto como estratégico, quando fornece pistas ao interlocutor, para que ele compreenda a referência dada no cotexto, uma vez que o termo anteriormente apresentado possa não ter sido compreendido.

Além disso, a anáfora por hiperonímia, por vezes, é acompanhada de um adjetivo ou uma locução adjetiva. Nestes casos, a função (re)categorizadora da seleção anafórica ocorre a partir de um termo classificatório e de maneira explícita. Ainda acrescenta-se que, quando a 
retomada correferencial ocorre com hiperonímia e hipônimo, respectivamente, há um caso de "anáfora especificadora" (KOCH, op. cit., p. 267), em que se apresentam esclarecimentos ou especificações sobre o objeto de discurso.

Há também possibilidade de o locutor selecionar uma expressão anafórica por termo genérico/neutro. Este procedimento pode ser observado no termo "companheiro" ou “companheira" - não apenas como vocativo, mas também como expressão referencial selecionado pelo ex-presidente da República Luis Inácio Lula da Silva para se referir aos políticos do Brasil e do exterior ${ }^{29}$. Como ilustração, lembremos a formulação "Companheiro Bush" utilizada por Lula para mencionar o ex-presidente norte-americano George Bush. O tom apresentado caracterizava-se pela informalidade e pela aproximação locutor e interlocutor. Isto nos permite afirmar a possibilidade de se criar uma imagem discursiva de si e do outro também na maneira como se nomeia e se constrói um objeto de discurso. Deste modo, os termos genéricos/neutros não podem ser vistos como não estratégicos; o fato de selecioná-los e apresentá-los já indica uma escolha do locutor e um possível posicionamento. É, pois, também na rede referencial que se apresentam pistas que orientarão o interlocutor para determinadas construções de sentido.

Em relação às descrições nominais, o uso delas implica um recorte, ou seja, um direcionamento por parte de quem as seleciona, na medida em que certas características do objeto de discurso são evidenciadas e outras silenciadas. O que é posto em evidência revela tanto a posição social e ideológica que o locutor ocupa, quanto indica a tentativa de orientação de olhares a qual corrobora outras estratégicas argumentativas utilizadas no discurso.

A recorrência, ou a reiteração, de certos recortes - na rede referencial tanto de um determinado discurso quanto naquelas construídas em outros que circulam socialmente e dialogam entre si - pode intervir no potencial de pluralidade de sentidos, uma vez que se privilegia um olhar em vez de outro e se cria certa regularidade no modo de ver e no de entender determinada realidade empírica, que pode ser reconstruído discursivamente a qualquer momento.

Tal efeito pode ser alcançado por meio da utilização de expressões nominais referenciais, pelas quais se poderá criar um modo de ver específico, conforme o que é evidenciado e reforçado nas formulações linguísticas nominais. Nestes casos, o nome-núcleo, metafórico ou não, cumpre papel crucial, pois é a partir dele que se atribuirá uma classificação

\footnotetext{
${ }^{29}$ Pesquisa realizada por CEREJA, W. Significação e Tema. In: BRAIT. B. (org). Bakhtin. Conceitos-Chave. São Paulo: Contexto, 2007. p.201-223.
} 
ao objeto de discurso, a qual poderá ser mantida, enfatizada ou alterada durante o desenvolvimento do discurso e retomadas em outros dizeres.

Cabe-nos também salientar que algumas formulações referenciais se especificam por serem complexas em relação à sua seleção, ao seu entendimento e à construção da rede referencial, como ocorre no caso dos encapsulamentos, das anáforas indiretas e das metafóricas, estratégias de referenciação sobre as quais discorremos nos itens 1.4.1, 1.4.2 e 1.4.3.

\subsubsection{Encapsulamento e anáforas complexas}

O encapsulamento corresponde à sumarização de um segmento - já apresentado no discurso (anáfora) ou que será mencionado (catáfora) - por meio de uma forma pronominal neutra (isto, isso, aquilo etc.) e/ou de um sintagma/expressão nominal (definida, indefinida). Neste último caso, a seleção poderá categorizar uma proposição, rotulando-a de maneira avaliativa ou aparentemente neutra. Francis (1994) denominou nominalizações a essas rotulações resultantes de encapsulamentos e destacou que a função dessas é a de transformar proposições em entidades.

Para González Ruiz (2009), esse tipo de mecanismo de coesão consiste de um sintagma nominal definido, cujo núcleo - substantivo - retoma um antecedente textual de extensão e de complexidade conceptual diversas, de modo a sumarizá-lo. O autor afirmar que:

A natureza fórica dos substantivos encapsuladores é evidente se levarmos em conta que o laço anafórico entre o antecedente e sua anáfora (elemento que se entende total ou parcialmente por relação àquele) sustenta-se no princípio da dependência interpretativa: em uma relação de coesão anafórica, um elemento textual necessita de outro para estabelecer univocamente sua referência (GONZÁLEZ RUIZ, 2009, p.248) ${ }^{30}$.

Quando um encapsulamento é selecionado, o segmento sumarizado torna-se um novo objeto de discurso, o qual se instituirá em uma cadeia referencial e poderá se apropriar de outras categorizações, conforme o encaminhamento dado pelo locutor. Assim, caso ocorram

\footnotetext{
${ }^{30}$ Tradução livre. La naturaleza fórica de los sustantivos encapsuladores es evidente si tenemos en cuenta que el lazo anafórico entre un antecedente y su anáforo (elemento que se entiende total o parcialmente por relación a aquel) está sustentado en el principio de la dependência interpretativa: en una relación de cohesión anafórica un elemento textual necesita otro elemento textual para establecer unívocamente su referencia.
} 
rotulações sucessivas de um mesmo segmento, possivelmente, haverá recategorizações durante o discurso.

Esse tipo de estratégia de referenciação corresponde a uma anáfora complexa (Koch, 2008a; Consten e Knees, 2008), pois exige, tanto do produtor de texto, quanto do interlocutor, uma habilidade cognitiva, já que o primeiro precisa ter em mente, de maneira clara, o que vai encapsular e o segundo, identificar o segmento encapsulado, para interpretá-lo.

De acordo com Consten e Knees (op. cit.), as anáforas complexas servem não só para resumir/condensar uma informação dada, como também para ajudar na progressão do fluxo de informações do discurso. Os efeitos que essa estratégia pode ter sobre o discurso ocorrem de maneira diferente, quando o encapsulamento é apresentado por um pronome neutro, ou quando este vem acompanhado de uma seleção nominal.

A complexidade implicada nesse tipo de referenciação consiste de dois fatores. $\mathrm{O}$ primeiro relaciona-se ao fato de o segmento encapsulado ser considerado abstrato, uma proposição (estados, processos, acontecimentos, fatos); já o segundo, à extensão do segmento sumarizado o qual pode ser mais longo que a sentença encapsuladora. Isto pode resultar em ambiguidade e, assim, dificultar sua interpretação, alcançada, por vezes, por meio de inferências ou de deduções.

Ainda conforme Consten e Knees (2008), ao encapsular um segmento textual, é possível construí-lo discursivamente de algumas maneiras. Uma delas corresponde à categorização dada pela própria seleção da expressão nominal, pela qual é possível avaliar, rotular (Esse acontecimento/Esse fato, por exemplo). A outra se relaciona ao verbo utilizado após o encapsulamento. Neste caso, o verbo colabora na produção de efeitos de sentido do objeto de discurso, ou seja, cria-se uma determinada imagem, de acontecimento, de fato, de estado, de processo etc., conforme a seleção verbal. Um exemplo apresentado pelas autoras trata-se do verbo acontecer: "Isso aconteceu”, o que rotula a informação como acontecimento, mesmo sem a utilização de uma nominalização.

Koch (2008) afirma que alguns rótulos indicam uma atitude metaenunciativa do locutor, pois sugerem uma postura dele - aproximação ou distanciamento, crítica, ironia etc. em relação a algum segmento encapsulado. No discurso político, não ocorre de modo diferente, mesmo que haja especificidades condizentes às condições específicas de produção. 
Pelo exposto, o encapsulamento pode ser um tipo de estratégia de referenciação complexo em relação a seu entendimento e a sua seleção. Esta complexidade também ocorre com as anáforas indiretas e associativas, assunto que será tratado no próximo item.

\title{
1.4.2. Anáforas indiretas
}

A ativação de um objeto de discurso ocorre de maneira não ancorada ou ancorada. No primeiro caso, ele é apresentado pela primeira vez e não tem âncora no texto. No segundo, embora também seja um referente textual novo, ele mantém algum tipo de associação cognitiva com outros objetos de discurso já apresentados no cotexto ou presentes no contexto sociocognitivo dos participantes, fato que ajudará o interlocutor a interpretar esse referente novo por inferência - são as denominadas anáforas indiretas. A respeito disto, Cavalcante e Koch (2007) propõem que esses tipos de anáforas promovem, ao mesmo tempo, a ativação de um referente e a reativação de outro (ou de um cenário inteiro) a partir de uma recuperação indireta. Isto se torna evidente nos casos de categorizações metafóricas, como as próprias autoras afirmam.

Em relação às anáforas indiretas, para interpretá-las, são exigidas do interlocutor operações mais complexas de ordem conceitual, em que um antecedente pode ser recuperado de maneira indireta (Schwarsz-Friezel e Consten, Knees, 2007; Koch, 2008a).

Para Koch (2008a, p.270):

\begin{abstract}
Têm-se anáforas indiretas toda vez que um novo objeto-de-discurso é introduzido, sob o modo do dado, em virtude de algum tipo de relação com elementos presentes no co-texto ou no contexto sociocognitivo, passível de ser estabelecida por associação e/ou inferenciação. Um subtipo dessas anáforas são as chamadas anáforas associativas.
\end{abstract}

Assim, no caso das anáforas associativas, elas não apresentam uma relação de correferência, ou seja, não há retomada, mas sim remissão. De acordo com Koch (2008a, 2005b), incluem-se, nesses tipos de expressões anafóricas, relações meronímicas - todas aquelas em que existe a noção de ingrediência. A autora ainda afirma ser necessário selecionar termos linguísticos pertencentes a um mesmo campo lexical, para que haja reconhecimento dos referentes textuais. 
Já para Schwarz-Frieze, Consten, Knees (2007), a anáfora indireta consiste de uma expressão nominal definida que não tem um antecedente explícito e, assim, é ancorada, por meio de um processo cognitivo, a algum elemento do texto de maneira associativa (visão tradicional). Para as estudiosas, há alguns tipos de anáforas indiretas. A diferença principal, como também foi apontado por Koch (2008a), reside no fato de que, enquanto, em alguns casos, há a necessidade de ativar um conhecimento semântico, em outros, é requerido um conhecimento conceptual mais geral para sua interpretação. A respeito disto, podemos incluir também casos de anáforas metafóricas.

\subsubsection{Anáforas Metafóricas}

Conforme Skirl (2007), há muito que ser examinado sobre as anáforas metafóricas. As pesquisas, tanto das teorias sobre metáfora quanto das anáforas, não foram ainda suficientes para explicá-las, pois, na maioria das vezes, os pesquisadores concentraram-se apenas em seus campos de pesquisa, sem fazer associação entre eles.

Para o autor, há diferentes tipos de anáforas metafóricas, os quais podem ser encontrados em vários enunciados, desde os do cotidiano até os mais específicos, como o do jornalismo. Um dos casos de anáfora metafórica dá-se quando da retomada de um referente textual pela seleção de uma formulação linguística, cuja natureza ontológica é diferente daquela do objeto retomado, como: Um homem $\rightarrow \mathrm{O}$ elefante ${ }^{31}$. Neste caso, a primeira seleção é acompanhada por um artigo indefinido, já a outra, por um definido. Por ser uma anáfora direta, um processo correferencial, a identificação do endereço cognitivo torna-se mais fácil para o interlocutor, assim, também a compreensão do sentido metafórico apresentado. Mesmo assim, existe a necessidade de ativar conhecimentos do cotexto e do contexto situacional - "um modelo mental do mundo textual" (Skirl, 2007, p. 104) - para reconhecer as propriedades associadas ao objeto de discurso (no caso, um homem), as quais podem ser características do próprio animal (elefante: peso, tamanho etc.), ou ser uma atribuição dada a ele (medroso, por exemplo).

Dessa maneira, esse tipo de anáfora metafórica direta colabora não só para dar continuidade à rede referencial, como também para atribuir outras características ao objeto de discurso que ajudam na construção de um modelo mental sobre ele de maneira, até mesmo, a (re) categorizá-lo. 
As anáforas metafóricas também podem ser indiretas ou associativas. Sua identificação e compreensão dar-se-ão do mesmo modo que as não metafóricas, ou seja, o interlocutor deverá manter algum tipo de associação cognitiva com outros objetos de discurso já mencionados no cotexto.

Além disso, para Skirl (2007), a compreensão de uma anáfora metafórica consiste de uma atividade mais difícil do que a de uma metáfora predicativa (A é B), já que, nesse processo cognitivo, há necessidade de identificar tanto o objeto retomado, quanto o conteúdo metafórico associado a ele por meio de uma anáfora indireta/associativa metafórica. $\mathrm{O}$ autor também salienta que o tópico discursivo em questão cumpre papel importante para que o interlocutor consiga chegar a essa identificação.

Dessa maneira, a identificação de uma anáfora metafórica vai além do reconhecimento de uma determinada palavra ou expressão referencial, tendo em vista que o sentido metafórico de um objeto de discurso constitui-se na rede referencial. Tal procedimento implica: a ordem de seleção das formulações linguísticas referenciais (informações anteriores e posteriores, categorização e recategorização); o cotexto; o tópico discursivo; a situação de interação; o conhecimento de mundo partilhado e, ainda incluímos, a inter-relação de cadeias referenciais.

Os dados contextuais e os cotextuais dão o entorno necessário para que se crie um modelo mental do objeto de discurso, cujas características atribuídas constituem-se por associações metafóricas. Tal complexidade evidencia-se no caso das anáforas associativas/indiretas. Nestes casos específicos, as âncoras cognitivas são constituídas por analogias, entre sistemas conceptuais distintos, efetivadas por inferências ou por pressuposições, a partir de um modelo mental do mundo textual (Skirl, 2007).

De modo geral, a respeito das anáforas metafóricas, entendemos que, ao serem selecionadas, inserem-se em um processo caracterizado por ser inter-referencial, ou seja, na ativação ou na retomada de um objeto de discurso, está implicado outro, ou outros, que pode levar o interlocutor a associar certas características e construir sociocognitivo e discursivamente um objeto de discurso em específico. É o que foi observado por Cavalcante e Koch (2007), como indicamos, sobre alguns tipos de anáforas que promovem, ao mesmo tempo, a ativação de um referente e a reativação de outro (ou de um cenário inteiro).

Nesse viés, reforça-se a ideia de o sentido metafórico de dado objeto de discurso nem sempre se contemplar em uma unidade linguística, ou seja, nem sempre pela retomada, mas sim pode ser observado na dinâmica do discurso, na mobilização de vários objetos de 
discurso, que levam a interpretações metafóricas específicas. Assim, propomos que para se construir sentido de uma entidade que, a priori, insere-se em um domínio abstrato do conhecimento, por exemplo, há a possibilidade de serem selecionados vários objetos de discurso e de organizá-los em cadeias referenciais inter-relacionadas, as quais orientam o sentido metafórico por estarem inseridas em uma proposta de sentido sobre determinado tema.

Portanto, retomemos o pressuposto de a condição específica de produção e as especificidades do gênero discursivo corresponderem a dados contextuais e discursivos significativos, os quais colaboram nesse processo de construção de objetos de discurso com sentido metafórico, já que o dizer se relaciona com quem diz, onde diz, para quem diz e com a razão a partir da qual se diz, e a questão da referência não pode desconsiderar isto. A discussão que se apresenta, acreditamos, fornece subsídios para que analisemos as metáforas e as redes referenciais em um campo específico da atividade humana, em pronunciamentos políticos presidenciais, que recebem influência tanto de quem os profere quanto para quem são proferidos, em especial em práticas políticas internacionais. 


\section{CAPÍTULO III}

\section{CONDIÇÕES DE PRODUÇÃO DAS PRÁTICAS DISCURSIVAS NO CONTEXTO DA POLÍTICA INTERNACIONAL}


Deve-se ressaltar que o poder não apenas aparece "nos" ou "por meio dos" discursos, mas também que é relevante como força societal "por detrás" dos discursos. (Grifos do autor)

van Dijk, 2010

Examinar discursos e processos de referenciação é ir além das palavras. Isto porque as seleções lexicais e suas organizações consistem em decisões, cujas razões também estão por detrás delas. Neste viés, no campo político, sabemos que há características singulares a partir das quais as práticas discursivas recebem particularidades. Entre estas especificidades, a existência de relações de força entre grupos já faz que a ação política seja repleta de estratégias discursivas, que possibilitam encaminhamentos de olhares, julgamentos e autopromoções. A elaboração do discurso político, portanto, implica a busca pelo poder e, ao mesmo tempo, pode ser entendida como um exercício inserido na disputa de dominação societal. Os próprios políticos têm a consciência da importância do discurso para esses propósitos políticos, segundo Chilton (2004). A este respeito, ao observamos o segmento (1), correspondente ao discurso de posse do ex-presidente da República Luís Inácio Lula da Silva em 2003 (anexo 01), temos que se confirma a posição desse estudioso:

$(01)$

E eu estou aqui, neste dia sonhado por tantas gerações de lutadores que vieram antes de nós, para reafirmar os meus compromissos mais profundos e essenciais, para reiterar a todo cidadão e cidadã do meu País o significado de cada palavra dita na campanha, para imprimir à mudança um caráter de intensidade prática, para

30 dizer que chegou a hora de transformar o Brasil naquela nação com a qual a gente sempre sonhou: uma nação soberana, digna, consciente da própria importância no cenário internacional e, ao mesmo tempo, capaz de abrigar, acolher e tratar com justiça todos os seus filhos.

Assim, é somente no e pelo discurso que se torna possível comandar, abrir espaços de discussão e de deliberação, legislar, desenvolver tratados e alianças, prometer, negociar, convencer e persuadir; atividades inerentes à instância política e, consecutivamente, à cidadã, visto que é também nas práticas discursivas que essas duas interagem. Nesta direção, em cada situação da política, o discurso é organizado de maneira específica e estratégica, 
principalmente, se pensarmos nos pronunciamentos feitos por um presidente da República, que são programados e planejados.

É nessa direção que discorremos, neste capítulo, a respeito das especificidades do discurso político, sobretudo, do presidencial nas relações políticas internacionais. A partir do exposto, discutimos sobre os fatores que dão corpo à configuração de situações específicas da política externa do ex-presidente da República Luís Inácio Lula da Silva, em que as práticas discursivas surgem em busca de modificar cenários globais, atualmente, em transformação de diversas ordens. Para tal propósito, respaldamo-nos em estudos do campo da ciência política (Vizentini, 1999, 2008; Almeida, 2012) e do discurso político (Aquino, 1997, 2003, 2005; van Dijk, 2010, Chilton, 2004; Montero, 2009, entre outros).

\subsection{Discurso como prática do político}

Para Aristóteles, a natureza humana caracteriza-se pelo viver em sociedade (polis) e pela capacidade de relacionar-se uns com os outros por meio da linguagem. O filósofo assinala que o ser humano é um animal político e, por tal razão, seu comportamento linguístico-social não é isento de propósito. Assim, uma vez que o discurso é prática social, ele carrega em si atitudes de construir relações sociais específicas, de obter poder e controle; ações inerentes à vida em sociedade.

Chilton (2004) parte desse pressuposto e afirma que a atividade discursiva, na qual são ativados saberes transmitidos culturalmente, serve às necessidades do político, este entendido, nesta parte, em seu sentido amplo, o homem em sociedade. Assim, de acordo com esse autor, a ação política varia conforme a situação específica em que os participantes estão engajados. Do ponto de vista micro, política pode ser considerada tanto cooperação - como ocorre nas práticas e nas instituições sociais que têm por objetivo resolver interesses de classes a respeito de dinheiro, de influência, de valores etc. - quanto disputa de dominação, conflitos de interesse entre grupos. Neste conceito de política, que pode ser entendido como política diária, incluem-se os discursos dos cidadãos em protestos, em apresentações de propostas cívicas e em outros tipos de manifestações e de reuniões. Isto significa afirmar que grupos - por exemplo, quando se manifestam em busca de direitos sociais, raciais etc. elaboram um discurso o qual também pode ser visto como político, pois a situação social assim o determina. 
Já em seu sentido macro, a política pode ser considerada uma disputa estabelecida entre indivíduos que almejam, por um lado, alcançar ou manter um poder e, por outro, resistir a ele. Neste extremo macro da política, em que se insere o corpus deste trabalho, existem instituições políticas do Estado, nas quais há normas concernentes à constituição, aos códigos civis e criminais, a partir das quais os políticos estão engajados com o propósito de alcançar o poder dominante e nele se manter. Os discursos destes indivíduos ou das instituições das quais eles vêm, nestes casos, têm caráter oficial e servem como interface, ou seja, tornam públicas, de certo modo, algumas informações do espaço político dominante, que é reservado à minoria.

Para Montero (2009), os discursos institucionais e os diários, dos cidadãos, constroem o tecido social e, por tal razão, não se pode separá-los, a não ser por conta dos objetivos de uma análise discursiva, em que se torna necessário constituir um corpus de pesquisa. Nesta direção, nossa atenção está voltada, especificamente, para os discursos da política em seu sentido macro. No primeiro instante, discutimos a respeito do discurso político de modo geral, entendendo-o não como um gênero discursivo, mas como uma classe de gêneros pertencente a um domínio social, tal como já destacaram van Dijk (2010) e Aquino (2003).

Nesse viés, nas práticas políticas (macro), circulam discursos estabilizados relativamente. Existem debates, entrevistas, pronunciamentos, entre outros, nos quais normas e interesses compartilhados inscrevem-se e são evidenciados por meio de seleções linguísticas diversas organizadas nos discursos. Assim, a política envolve diversos gêneros discursivos elaborados para interesses específicos e, em todos eles, apresenta-se discussão, principalmente, pelo fato de haver, nessas circunstâncias, a tentativa de um grupo controlar ações e/ou mentes de outros. Tal prática foi denominada por van Dijk (2010) poder social, que é organizado e institucionalizado por um escopo social específico, como compreendemos o da política em seus dois sentidos.

A respeito dos contextos situacionais da política (sentido macro), sabe-se, como mencionamos, que o fazer político implica o uso estratégico da linguagem, pelo qual grupos constroem realidades discursivas na tentativa de alcançar, de manter e de sustentar um poder, quer seja de um Estado, quer, por exemplo, de um órgão internacional. Para que estes propósitos sejam atingidos, de acordo com Charteris-Black (2011), o político necessita elaborar discursos, pelos quais ele possa orientar uma imagem de si, de seu grupo e de suas propostas de tal modo que seu auditório passe a confiar em seus projetos e em sua capacidade 
de executá-los. Por conta disto, é possível dizer que a construção do ser confiável, digno de crédito, pauta-se por condições específicas da prática política, em que há necessidade de negociação, de acordo e, principalmente, em sistemas ou contextos democráticos, do consentimento da maioria.

Tais práticas discursivas dos políticos podem ser compreendidas como um exercício legitimado, uma vez que, além de elas serem regidas por normas institucionais, são credenciadas por um escopo social que atribuiu poder e status a esses políticos para que eles possam falar e agir em nome dos interesses de um grupo. É, portanto, a partir do momento em que se adquire esse reconhecimento, que um indivíduo tem direito de participar de determinados espaços de discussão.

Nesse viés, visando ao lugar da governança, cada qual utiliza as possibilidades de comportamentos discursivos de que dispõe de modo estratégico. Em razão disto, os discursos políticos são dinâmicos e, geralmente, dizem mais do que aparentam ${ }^{32}$, pois criam olhares diversos sobre situações do mundo, isto é, são práticas que moldam a realidade empírica e, ao mesmo tempo, são moldadas por ela. Portanto, é a partir desta malha de relações de poder tecida por palavras e por comportamentos específicos - que os políticos propõem programas, justificam decisões, criticam posturas e ideias adversárias para autopromover a si e conseguir o apoio dos cidadãos ou de outros grupos sociais e políticos (Charaudeau, 2006). Estabelecese, pois, um jogo em que há tentativas diversas de persuasão e de sedução, formuladas e reformuladas conforme a ação e a reação de determinados auditórios e das situações interativas nas quais os discursos são produzidos.

A respeito desse último fator - as situações interacionais específicas em que os discursos são elaborados e apresentados - interessa-nos indicar a metáfora utilizada por Charaudeau (2006), a partir da qual ele explica a complexa configuração dos eventos políticos. O autor afirma que a instância política ${ }^{33}$ é composta por um centro, os representantes do Estado, dos governos, dos parlamentos etc., e por vários satélites, entre os quais estão: as instâncias financeiras, jurídicas, técnicas e científicas, que dependem do poder público em relação à nomeação dos chefes dos órgãos que as representam e à sua influência sobre a bolsa de valores, o consumo, entre outros; os organismos supranacionais, os internacionais e não governamentais, os quais são tanto dependentes de Estados e seus

\footnotetext{
${ }^{32}$ Como pode ocorrer com outros discursos.

${ }^{33}$ Compreendemos que se trata do sentido macro de política.
} 
respectivos governos quanto autônomos, por deterem o poder de pressionar países, estabelecer regras de funcionamento, como o direito internacional.

A estas questões, podemos afirmar, utilizando de outra metáfora, que a vida em sociedade consiste de uma rede interconectada de práticas diversas em campos de certo modo distintos, mas internalizados, como da economia, da educação, da mídia etc., e entendemos que a política (macro) envolve e é envolvida por todos eles. Nesta acepção, é, pois, um sistema aberto, de constante formação e transformação, cujas ações, ao mesmo tempo em que se estabilizam relativamente, diversificam-se por conta de estabelecerem constante diálogo com as mudanças sociais e, por essas práticas serem produtos de uma rede de relações múltiplas entre indivíduos, a qual se (re)define no escopo social multifacetado.

Quanto a essa diversidade de situações instauradas no campo da política, pode-se afirmar que os políticos estabelecem relações diversas com o cidadão, seu parceiro principal, a partir da imagem que eles criaram a respeito deste e dos propósitos específicos que motivam comportamentos textual-discursivos. O discurso recebe ajustes, e as estratégias discursivas, portanto, são conduzidas a partir do que se presume estar acordado com as expectativas daqueles a quem o político dirige seu discurso.

Em consonância com a afirmação de Aquino (2005), nenhum político aceita participar de um encontro público de modo ingênuo. A situação na qual ele interage é de seu conhecimento e, por tal razão, joga-se de modo estratégico na tentativa de validar uma proposta e direcionar uma leitura positiva de sua imagem pública. Ainda conforme essa autora, pelo fato de poder haver crenças, valores e interesses múltiplos em cena, reconhece-se a possibilidade de a interação não ser bem-sucedida, mesmo quando existe um planejamento do discurso.

Nesse viés, consideramos que, no campo político, a atividade discursiva consiste de tentativas de possibilitar aos interlocutores a compreensão do que se diz por meio de um recorte avaliativo, a partir do qual se torna viável atribuir verossimilhança àquilo que se propõe estar ou não correto em termos de propostas ou de comportamentos a respeito daqueles que compõem o grupo político sobre o qual se fala.

Além disso, parece-nos significativo salientar que, quando um discurso político é público, isto é, quando o cidadão tem possibilidade de entrar em contato com ele, os grupos políticos, consecutivamente, também têm acesso à instância cidadã e, a partir disto, sobre ela tentam influir. Com isto, queremos dizer que se trata de um efeito (um parecer) de acesso à 
instância política, pois o que se apresenta é o produto de reuniões de planejamento restritas, de pouca circulação - como as de gabinete. Para van Dijk (2010), o alcance do acesso, bem como o que pode ser acessado, é uma tentativa de controle e implica um poder legitimado.

Assim sendo, podemos considerar o discurso e os eventos elaborados para sua divulgação como ações para fins políticos. A partir disto, embora outros falares legitimados sirvam de interface entre a instância política e a cidadã - como o midiático, o didático, os do cotidiano etc. - não se pode negar a influência do discurso (do) político na construção do conhecimento correspondente à instância política em si e àqueles que dela fazem parte. Além do mais, o que ocorre na política (macro), isto é, o evento em seu estado bruto, é selecionado, recortado e constituído em realidades discursivas, as quais podem encaminhar maneiras diversas de compreender tais eventos, conforme o olhar do locutor e o diálogo entre o discurso deste e seus interlocutores.

De fato, o que ocorre é mais do que isso. Acreditamos existir uma interface discursivosociocognitiva atrelada a esse processo de fazer que o outro compreenda, de modo específico, o que ocorre na política (macro) e se torne disposto a aceitar determinados posicionamentos. Tal discussão é apresentada a seguir.

\subsection{Interface discursivo-sociocognitiva}

Partimos do pressuposto de que conduzir o outro a ver determinado objeto de discurso a partir de um viés específico corresponde ao produto do entrelace entre conhecimentos velhos e novos - que são ativados durante o delinear do discurso - e associados às representações mentais sobre eventos políticos, que são socialmente partilhadas entre grupos e instituições. Para entender este processo, torna-se necessário discutir a respeito da cognição política (van Dijk, 2010).

Nessa direção, retomamos a discussão, apresentada às páginas 54-56 deste trabalho, a respeito da acepção de van Dijk (2010) sobre modelos de evento e, em específico, indicamos como o autor estende tal conceito para o campo político. Esse estudioso afirma que os políticos constroem modelos mentais de eventos comunicativos - representações subjetivas e avaliativas - correspondentes ao domínio da política (macro) e organizam seus discursos a partir da imagem que criam a respeito de si, dos outros participantes e da situação de interação em que se encontram. Estas representações mentais de eventos, no campo político, constituem-se por meio de algumas categorias, como consta do seguinte exemplo dado pelo autor (VAN DIJK, 2010, p. 221): 
- domínio como um todo (por exemplo, a política);

○ ação societal como um todo (legislação);

○ situação corrente (hora, localização);

- circunstâncias correntes (projeto de lei a ser discutido);

○ interação corrente (debate político);

○ gênero discursivo corrente (discurso);

- os vários tipos de papéis sociais dos participantes (falante, MP, membro do Partido Conservador, branco, masculino, idoso etc.);

- as cognições dos participantes (metas, conhecimentos, crenças etc.)

Nessas situações, os participantes necessitam ativar vários conhecimentos - os mais gerais associados aos específicos do evento em questão - os quais, ao mesmo tempo, orientam a elaboração do discurso e restringe-a. Além do mais, tem-se sugerido, conforme van Dijk (2010), que os gêneros discursivos são delineados contextualmente (modelos mentais de eventos) antes mesmo que textualmente.

De todo modo, podemos dizer que o discurso político, como os outros, define-se em termos contextuais (situacionais e cognitivos) e, estes, ao mesmo tempo, estruturam o agir em sociedade, regulam-no. Há, pois, uma interface sociocognitiva, e também discursiva, entre o político e o evento de que ele participa, pela qual mundos discursivo-cognitivos são construídos a respeito dos agentes políticos e de suas ações, os quais são, de certo modo, percebidos e avaliados por aqueles a quem os discursos são dirigidos, tal como é o caso da instância cidadã.

De maneira geral, elaboramos a figura a seguir, a fim de ilustrar esse processo de construção de sentido do que é evidenciado no discurso político:

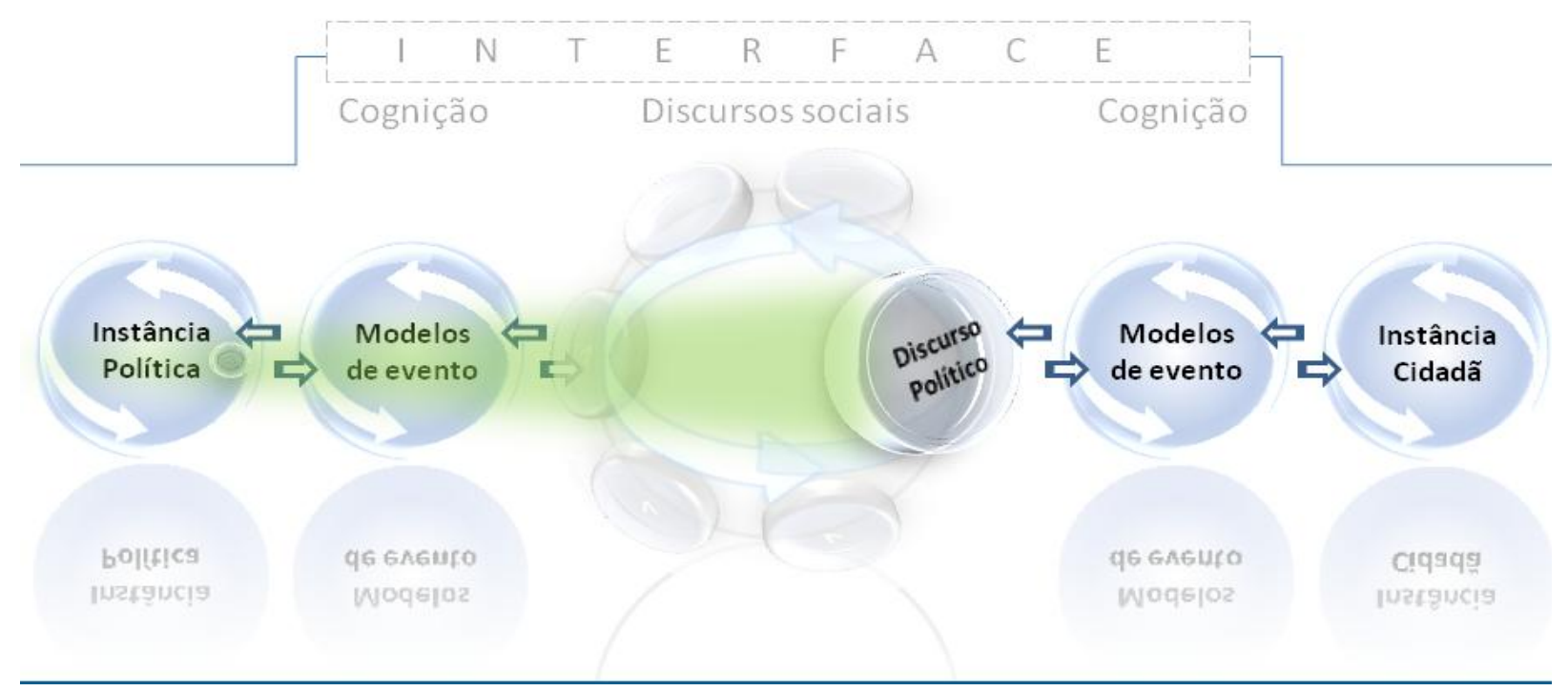

Figura 1. Interface discursivo-sociocognitiva do processo de construção de sentido. 
$\mathrm{Na}$ figura 01, ilustramos a interface existente, em específico, entre as instâncias políticas e cidadã e apresentamos que o modelo cognitivo de evento, constituído pelos políticos, regula a elaboração de seus discursos, bem como a construção de sentido dos discursos políticos por parte dos interlocutores também é regulada pelos modelos que estes criam e compartilham no momento da interação. Neste processo de dar sentido ao que ocorre na instância política, essas representações mentais estão imbricadas na dimensão pragmática do campo político, em que determinados procedimentos discursivos são selecionados como forma de controle do que deve ser visto ou apagado a respeito do evento em seu estado bruto.

Ainda em relação à figura 01 , tendo em vista que o homem não possui acesso direto à realidade, uma vez que a relação que ele tem com esta sempre é mediada pelo discurso e por suas percepções constituídas cognitivamente, pode-se conceber que a prática discursiva do campo político se molda a essas imagens e, nesta inter-relação, atua como tentativas de modificar quer sejam contextos cognitivos, quer situações político-sociais. Neste viés, na busca de apoio de um determinado público, o discurso de um político, e de seu grupo, concorre com as imagens já pré-concebidas pelos interlocutores e, por tal razão, recorre-se a estratégias discursivas que, ao mesmo tempo, colaboram na constituição do discurso e no encaminhamento de olhares.

Ao assinalarmos o fato de que o discurso político está entrelaçado a um modelo de evento e é moldado a este e por este, tratamos também de conceber que um determinado recorte (como indicado na figura 01), específico da instância política, corresponde a uma escolha do político a respeito do que deve ganhar destaque publicamente e de que maneira isto deve ser visto. Trata-se de buscar que o outro crie ou mantenha certas representações cognitivas sobre aquilo que é evidenciado no discurso, uma vez que tais imagens mentais regulam o que as pessoas falam, pensam e como elas agem nas interações sociais.

Entre as possibilidades de atingir tais resultados, destacamos que ativar determinados objetos de discurso, de modo a evidenciar alguns aspectos julgados negativos, ou mesmo, a atenuar outros consiste de um procedimento discursivo, detrás do qual existem interesses múltiplos de assegurar modos de ver e de entender o que se passa na instância política e de conduzir a julgamentos específicos. Se estes forem construídos de acordo com a proposta enunciativa do político, delinear-se-á um caminho, no qual ele poderá alcançar ou manter determinados lugares em termos de poder político. Muito mais do que formular um discurso que atenda a um modelo de evento e à expectativa dos participantes, neste processo, a ativação de objetos de discurso - políticos, partidos, governos etc. - e sua negociação de 
sentido pode dar força à imagem pública do locutor e fazer que este aja alicerçado pelos seus interlocutores.

É nesse sentido que entendemos estarem as coisas por si só, para o homem, envoltas por palavras carregadas de intencionalidades diversas e, portanto, não estão soltas com sentidos fixos em dados espaços públicos de atuação humana. Elas fazem parte de uma relação de forças presente no discurso produzido pelo homem e para o homem, e este, como agente político, a elas recorre e as molda no discurso, para determinados fins.

Ao considerarmos tais afirmações, assumimos o postulado de que o homem está atrelado ao discurso e à sua condição sociocognitiva, assim como já indicamos no capítulo 1 deste trabalho. Neste viés, é que compreendemos constituir-se a tessitura entre ação e reação sociocognitivo-discursivas configuradas de modos diversos no jogo de relações de poder do homem político, em seu sentido amplo.

Salientamos, ainda, que os papeis sociais previstos nos modelos de evento e assumidos pelos políticos - candidatos, deputados, senadores, prefeitos, presidente da República etc. bem como seus posicionamentos ideológico-partidários e suas coalizões consistem de fatores que trazem certas particularidades significativas na elaboração de seus discursos e no modo como os interlocutores dialogam com estes.

Pelo exposto, entendemos, mais uma vez, que o exame da atividade discursiva requer um olhar que vai além do discurso, que leva em conta as especificidades da conjuntura político-social da qual os políticos participam. Nesta acepção, nos vários encontros ocorridos no campo da política, busca-se alcançar credenciamentos específicos que direcionam as formulações do discurso.

Entendemos ocorrer dessa maneira nas diversas ocasiões em que um chefe de Estado aparece publicamente e profere um discurso, já que a legitimidade de representar um país, conferida a esse político, é monitorada e avaliada por várias instâncias em diversos momentos de seu mandato. Há interesses diferentes entre os que compõem seu auditório - pessoas de seu país e do exterior - por conta disto, seus pronunciamentos fazem parte de um contexto situacional amplo e complexo, no qual estão envolvidos fatores de ordens nacional e global. Para os objetivos de nossa pesquisa, tais especificidades merecem atenção e serão, por isto, discutidas a seguir. 


\subsection{Discurso presidencial: práticas discursivas e relações de força na política interna e na externa}

O discurso presidencial, enunciado, então, por um presidente da República, a depender da situação interativa em que esse político se encontra, poderá constituir-se de discursos escritos, oralizados em pronunciamentos (como ocorre na ONU) ou, por exemplo, discursos em que também se articulam especificidades da fala e da oralidade, tais como são os elaborados em entrevistas, uma vez que, nestas ocasiões, a interação se molda à dinâmica do evento e, por conta disto, a prática discursiva do presidente precisa, por vezes, ajustar-se às ações do entrevistador e ao desenvolvimento do processo interacional, sem perder de vista a produção anteriormente planejada por uma assessoria.

Assim é que os discursos divulgados de políticos de alto escalão, como o do presidente da República, são cristalizados em textos escritos tidos como registros, que embasam o caráter institucional e, também, jurídico dessas práticas sociais, as quais devem ser organizadas a partir de uma agenda pública, envolvendo a elaboração de outros discursos - entre os quais, há os da imprensa do poder público, que divulga no site ou em outro tipo de interação a agenda internacional do presidente da República, do ministro das relações exteriores, do secretário geral etc. - possibilitando diálogos diversos entre eles. Tal procedimento revela, mais uma vez, um exercício do poder, já que os discursos escritos são planejados e, por isto, mais controlados (van Dijk, 2010).

Uma característica peculiar do discurso presidencial consiste de seu amplo alcance, uma vez que podem atingir milhões de pessoas de grupos diversificados em várias partes do mundo. Esta ampla dimensão ocorre, principalmente, pelo fato de essa prática discursiva imanar de uma figura central da sociedade, que exerce a direção superior da administração federal.

Além disso, o dizer de um presidente torna-se foco de atenção por parte de muitos em decorrência dos tópicos discursivos selecionados, relacionados a questões de ordem nacional e também global, e das funções por ele assumidas, descritas, no caso do Brasil, na Constituição da República Federativa do Brasil - tais como a de permitir que forças estrangeiras transitem ou mesmo permaneçam no país e a de manter relações com outros Estados estrangeiros com o intuito de realizar tratados, convenções e atos internacionais, os quais estão sujeitos a referendo do Congresso Nacional. Neste sentido. o pronunciamento de 
um presidente da República é de interesse para os governados, para outras nações, aliadas ou inimigas.

Em relação aos procedimentos dos discursos presidenciais, as características evidenciadas fazem-nos crer que haja uma preocupação acentuada nesse sentido. Isto porque, se por um lado, ele apresenta especificidades próprias do discurso político, assim como assinala Montero (2009, p.351),

No discurso presidencial, destacam-se as condições próprias do discurso político, pois se pretende persuadir, mobilizar audiências e gerar emoções (tanto positivas quanto negativas). É possível também produzir alianças, adesões e lealdades em seus receptores em relação à figura emissora, e ainda ódios e desconfortos, já que pode comover, agitando as emoções e os sentimentos da audiência" ${ }^{34}$.

por outro, a condição - correspondente a qualquer prática discursiva - de ter de responder e de se ajustar a um contexto histórico-social faz que um presidente da República tenha de adquirir, de manter/reforçar, no mínimo, um duplo credenciamento: alicerçar sua legitimidade como chefe de Estado perante os cidadãos - haja vista que esta pode ser questionada pela sociedade - e garantir, como representante máximo de seu país, que este seja reconhecido no cenário internacional.

De fato, tais características fazem que haja preocupação em termos de forma de acesso à figura do presidente da República e de seus pronunciamentos, para que se estabeleça e se perceba um consenso entre os valores apresentados por ele e a coerência de suas ações. Assim, é a imagem do presidente em sua verdade de troca discursiva que está em jogo e, consecutivamente, em âmbito internacional, a de um Estado o qual precisa de legitimação e de credibilidade.

Por tal razão é que as manifestações da fala de um chefe de Estado - as quais pessoas são expostas em várias situações sociais - são planejadas para que se ajustem à proposta de um grupo político dominante. Além do mais, o fato de a imagem de um presidente e a de seu governo terem de se manter positivas perante vários tipos de interlocutores promove a

\footnotetext{
${ }^{34}$ Tradução livre. En el discurso presidencial se destacan las condiciones propias del discurso político pues pretende persuadir, movilizar audiencias y producir emociones (tanto negativas como positivas). Puede además producir alianzas, adhesiones y lealtades en sus receptores respecto de la figura emisora, al igual que odios y malestares, puesto que puede conmover agitando lãs emociones y sentimientos de la audiencia
} 
necessidade de escolha dos tópicos, das formulações linguísticas, do encaminhamento dado aos discursos, de sua distribuição e, até mesmo, do estilo assumido pelo locutor.

Temos, ainda, que a formulação do discurso presidencial seja conduzida com certas particularidades, decorrente do fato de ele ser produzido para garantir eficiência em diferentes interações político-sociais, nas quais relações de força e negociações específicas entram no jogo. Além do mais, as normas que regularizam determinados encontros modificam-se, bem como os papeis sociais dos participantes. Nesta direção, pode-se dizer que o percurso necessário para se adquirirem certos credenciamentos no âmbito internacional não é o mesmo daquele correspondente à prática política da linguagem em sua dimensão nacional.

Nesse sentido, pressupomos que os lugares discursivos de um chefe de Estado são diferentes, quando ele interage no âmbito interno e no externo de seu país, em razão de não concebermos que seu poder seja reconhecido da mesma maneira, quando o propósito é assegurar a participação do Estado nas relações internacionais. Isto porque, nestes casos, vozes diversas e específicas são representadas e precisam ser credenciadas - a do povo de modo geral, a de empresários, a do governo, a de seu governante como representante de seu país no exterior, entre outras.

Nessa acepção, interessa-nos discutir algumas características da política interna e da externa, por acreditarmos que elas dão contornos diferenciados aos discursos presidenciais e, ao mesmo tempo, articulam-se em prol de uma proposta política maior - a do Estado.

\subsubsection{Discurso presidencial no domínio da política interna}

Em consonância com as afirmações de Tupynambá (2010), existe uma autoridade suprema na política nacional - do presidente da República e dos que compõem seu governo a qual exerce poder sobre os demais a partir de métodos subsidiados por leis aceitas como legítimas. Além do mais, destacamos que tal exercício relaciona-se à gestão da vida coletiva de uma sociedade, na qual há normas axiológicas que também servem, como as leis, como elementos de percepção e de julgamento dos comportamentos políticos e discursivos da autoridade máxima do país.

Do mesmo modo, na política interna de um país, as relações de força existentes configuram-se entre atores - políticos e seus partidos etc. - que disputam um poder no espaço nacional. Quando a manifestação discursiva é pública, eles interagem em situações 
caracterizadas, na maioria das vezes, por serem repletas de conflitos e de desavenças de opinião, principalmente, em campanhas eleitorais, em debates parlamentares etc. Estes procedimentos são considerados aceitáveis pelo fato de estarem previstos nas regras de convivência, existentes no espaço político nacional.

Nesse sentido, tal dinâmica, configurada nos espaços públicos de embate político nacional, corresponde a um "contrato de comunicação" (Charaudeau, 2006), que é reconhecido pelos participantes. Levando-se em conta que "todo discurso se constrói na intersecção entre um campo de ação, lugar de trocas simbólicas organizado segundo relações de força (Bourdie, 1982 $2^{35}$ ), e um lugar dos mecanismos de encenação da linguagem” (Charaudeau, 2006, p.52), os procedimentos discursivos dos políticos, em seu país, estão alicerçados por regras já aceitas, nas quais estão circunscritos seus papéis sociais e seus respectivos comportamentos nos espaços de discussão. Construções e reconstruções discursivas operam nos lugares assumidos no dispositivo desse contrato de comunicação.

É assim que também ocorre com o discurso presidencial, quando direcionado a um auditório nacional, na medida em que dialoga com as possibilidades de comportamentos que o político dispõe e que são permitidos na situação na qual ele está. Com efeito, existem expectativas a respeito do procedimento discursivo e de certas posturas de um chefe de Estado. Entre elas, no Brasil, algumas são exigidas por lei e registradas no Manual de Redação da Presidência da República, tendo como embasamento a necessidade de respeito aos princípios constitucionais de legalidade, de impessoalidade, de moralidade, de publicidade e de eficiência ${ }^{36}$.

Quando se trata do discurso presidencial proferido ao cidadão, em sua organização, há necessidade de conciliar formalidade e simplicidade para se adequar a esse público em questão. Ao examinar esse discurso, Preti $\left(2005\right.$, p. $\left.95^{37}\right)$ afirma que:

O discurso presidencial já está 'pré-moldado' a uma fórmula que vem dando certo ao longo dos anos: vocabulário simples, linguagem comum, algumas expressões populares, elaborada a partir de uma linguagem

\footnotetext{
${ }^{35}$ Bourdieu, P. (1982). Ce que parler veut dire. Paris: Fayard. Apud. Charaudeau (2006, p. 52).

${ }^{36}$ No manual de redação da presidência da República (2002), há a seguinte afirmação: "Não se concebe que um ato normativo de qualquer natureza seja redigido de forma obscura, que dificulte ou impossibilite sua compreensão. A transparência do sentido dos atos normativos, bem como sua inteligibilidade, são requisitos do próprio Estado de Direito: é inaceitável que um texto legal não seja entendido pelos cidadãos. A publicidade implica, pois, necessariamente, clareza e concisão".

Disponível em: http://www.planalto.gov.br/ccivil_03/manual/manual.htm

${ }^{37}$ Grifos do autor.
} 
descomplicada, toda construída na ordem direta. Quanto à adaptação do discurso à situação, observa-se a utilização de um grau moderado de formalidade quanto ao tom e postura de voz e corpo. Enfim, um discurso trajeto à moda 'esporte-fino', que não fere os ouvidos dos letrados e alcança o povo de modo geral, a massa.

Montero (2009), por sua vez, afirma que, a partir do momento em que o cargo de presidente da República é concedido a um político, determinados comportamentos correspondem à quebra de um protocolo. A respeito do que se espera ou não de chefes de Estado, a autora (op. cit. p. 353) entende que:

\begin{abstract}
Não se espera que eles façam o ridículo, que se deixem levar pelas emoções, no sentido de ter uma crise em público, que balbuciem ou usem uma linguagem incorreta ou destemperada. Existe um protocolo e um consenso, os quais respondem a uma forma de correção política, que, por sua vez, permite a ameaça, a vela; que permite a ironia, mas sem escárnio; que aplaude a frase aguda e a citação forte, mas condena o insulto; que entende o abandono de uma reunião (embora seja alarmante e considerado grave), mas condena a linguagem vulgar e o tom de voz alto. ${ }^{38}$
\end{abstract}

Embora seja usual que o planejamento do discurso presidencial ocorra em resposta a essas expectativas, compreendemos que as condições específicas de produção oferecem outros elementos que influenciam a prática discursiva de um presidente da República. Em razão de a manifestação discursiva consistir de uma ação social, além do papel assumido pelo enunciador, muito do que é aceito ou não em termos de comportamentos discursivos relaciona-se a um específico momento histórico, político e social, em que se encontra uma sociedade.

Para Aquino (2003), mesmo que haja um linguajar próprio pertinente a um grupo de pessoas de uma mesma área de atuação (tal qual na política), existem, por vezes, seleções lexicais específicas por conta da formação intelectual e das atividades exercidas por cada um. Ainda de acordo com a autora (op. cit., p. 196):

\footnotetext{
${ }^{38}$ Tradução livre. No se espera que ellos hagan el ridículo, que se dejen llevar por las emociones em el sentido de hacer una crisis en público, que balbuceen o que usen un lenguaje incorrecto o destemplado. Hay un protocolo y un consenso que responden a una forma de corrección política, que a la vez que permite la amenaza, la vela; que permite la ironía, pero no la burla o el chiste; que aplaude la frase aguda y la cita afilada, pero que condena el insulto; que entiende el abandono de una reunión (aunque es alarmante y se considera grave), pero que condenaría el lenguaje subido de tono y el tono alto de la voz.
} 
Embora não nos encaminhemos à discussão de questões filosóficas ou político-partidárias, podemos assinalar o quanto tem sido notório o fato de que o discurso utilizado pelos políticos está longe, muitas vezes, de ser compreendido pelo cidadão comum, ainda que estejamos começando a assistir a uma modificação nesse posicionamento, em virtude das mudanças ocorridas no quadro dos políticos em exercício.

Com efeito, no caso da sociedade brasileira, pode-se afirmar que houve modificação quanto a alguns posicionamentos tanto por parte de certos políticos quanto do cidadão comum, que findou com determinados protocolos nos últimos anos. Exemplo disto consiste de algumas formulações linguísticas selecionadas pelo ex-presidente Lula no Brasil, as quais se distanciaram do grau de formalidade esperado. Para ilustrarmos esta afirmação, selecionamos um segmento do discurso de posse do ex-presidente, em $1^{\circ}$ de janeiro de 2007 (Anexo 02):

(2)

$05 \quad$ Meus queridos brasileiros e brasileiras,

É com muita emoção que eu subo a este Parlatório para conversar um pouco com vocês. Hoje é para mim um dia de profunda emoção. Primeiro, porque ser Presidente da República do meu País, eu recebo isso como uma bênção de Deus, [...]

Eu me lembro de que quando fui dirigente sindical, a gente tinha até dificuldade de entrar no Congresso Nacional. Neste Palácio, nem pensar.

$[\ldots]$

As partes destacadas em itálico, em que podemos depreender um tom mais informal, revelam que as expectativas em relação às maneiras de dizer podem-se alterar, caso haja tanto mudanças conceituais em uma sociedade, delineadas historicamente, quanto alinhamento entre o linguajar, a imagem que se quer construir de si e as propostas políticas. Pode-se entender que esse modo de dizer criou condições ao político para que ele se aproximasse e alcançasse identificação com uma parcela da população brasileira, a qual o reconheceria, também pelo seu modo de falar, como um representante legítimo. Parece-nos possível afirmar que houve alteração no modelo mental até então existente a respeito de um chefe de Estado, fazendo que parte da população assumisse valores, anteriormente negados, e interpretasse o comportamento do ex-presidente de maneira aceitável. 
Nesse viés, o que se espera de um presidente da República em termos de comportamentos discursivos está estreitamente relacionado às conjunturas específicas de uma sociedade em determinada época. Isto corresponde a mais um fator que torna, de certo modo, singular o contrato de comunicação existente no cenário político nacional em comparação ao internacional.

Assim, temos que os contratos, que operam as práticas discursivas presidenciais, não são os mesmos nas relações internacionais. Há de se considerar o embate de relações de força configurado de modos diferentes, na política interna e na externa, como elemento desencadeador de processos interacionais, cujas ações, embora interligadas, recebem influência das circunstâncias políticas, sociais e culturais diversas e dos modelos de eventos constituídos por auditórios ímpares.

\subsubsection{Discurso presidencial no domínio da política externa}

Embora os discursos proferidos por um presidente da República em encontros entre chefes de Estado e/ou de governo, entre outros participantes, também alcancem um público maior, como o povo ou parte dele, eles recebem particularidades significativas. Como discutimos, há propósitos específicos que conduzem a determinados comportamentos discursivos. No caso do Brasil, esses objetivos são apresentados pelo Ministério das Relações Exteriores, o Itamaraty ${ }^{39}$. A respeito disto, destacamos a seguinte afirmação:

O Ministério das Relações Exteriores (MRE) é o órgão político da Administração direta cuja missão institucional é auxiliar o Presidente da República na formulação da política exterior do Brasil, assegurar sua execução, manter relações diplomáticas com governos de Estados estrangeiros, organismos e organizações internacionais e promover os interesses do Estado e da sociedade brasileiros no exterior.

Pelo exposto, nas relações exteriores, a preocupação, por parte daqueles que elaboram os discursos proferidos por um presidente da República e por este que os assume, debruça-se sobre a possibilidade ou a tentativa de se obter um poder global. Para tanto, é preciso

\footnotetext{
${ }^{39}$ Disponível em: http://www.itamaraty.gov.br/temas/acesso-a-informacao/institucional/conheca-o-ministerio. Acesso em 08 dez. 2012.
} 
conseguir alianças, promover uma imagem positiva do país e do governo, justificar tomadas de decisão, lidar com adversidades políticas e diferenças culturais etc.

Assim é que as manifestações discursivas de um presidente da República recebem particularidades no âmbito da política internacional por conta das próprias especificidades desse campo - que surgem e se redefinem em meio a mudanças sociais diversas - e do papel social que cumprem os atores desse cenário, entre os quais acreditamos existirem relações de força, por vezes, não apresentadas de modo explícito, sem a seleção de formulações diretas em seus discursos. Isto significa que, embora o conflito possa ser considerado como inevitável na vida política de modo geral, quando se trata de relações exteriores, há necessidade de trilhar outros caminhos em termos de práticas discursivas para que se obtenham, por meio da palavra, resultados que se distanciem de um conflito maior entre Estados e que se evitem, até mesmo, situações de guerra.

Nessa direção, queremos dizer que a interação efetivada nos pronunciamentos direcionados a chefes de Estado ou de governo, muitas vezes, consiste de ações políticas de disputa veladas - no sentido de serem, no e pelo discurso, encobertadas e vigiadas - de modo a dar mais ênfase a um estado de cooperação do que de oposição. Nesta acepção, Bolivar (2008, p.2) entende que: "Embora os insultos sejam aceitos em certos contextos, como parte da interação, no diálogo de confronto político, pode afetar as relações diplomáticas e, em longo prazo, infringir o diálogo democrático" 40

É preciso ainda observar que a tentativa de criar condições para que um Estado se insira em um cenário internacional de maneira a garantir um desenvolvimento político e econômico não se distancia totalmente de um projeto nacional, tal como o de justiça social (Vizentini, 2008). Neste viés, a ação política externa está estreitamente relacionada à interna e, de certa forma, essa relação compõe a agenda social e política de um país. Tem-se, logo, um chefe de Estado e seu governo que atuam também por meios discursivos, em territórios regulados de modos distintos, mas que estão interconectados, como já o dissemos.

Assim, ao mesmo tempo em que os discursos da política interna e da externa recebem encaminhamentos diferenciados, torna-se necessário haver alinhamento entre eles, a fim de que se reconheça coerência entre as ações e se fortaleça a credibilidade do governo, uma vez que este pode contribuir para a constituição de uma imagem negativa ou positiva do Estado;

\footnotetext{
${ }^{40}$ Tradução livre: Aunque lós insultos son aceptados en ciertos contextos como parte de la interacción, en el diálogo político confrontacional pueden afectar las relaciones diplomáticas y, a largo plazo, vulnerar el diálogo democrático.
} 
fator importantíssimo para a obtenção, por exemplo, de boas relações internacionais e, consequentemente, de negociações entre países.

Por tal razão, observar discursos da política exterior envolve discutir, ao menos de modo sucinto, algumas especificidades das relações internacionais as quais julgamos significativas para o propósito deste trabalho. Trata-se de levar em conta que os enlaces constituídos, no âmbito interno e no externo de um país, entrelaçam-se com as necessidades políticas, sociais e econômicas, que se formam e se reformam no percurso histórico, em que vários agentes políticos estão engajados.

Além disso, nas práticas discursivas, está imbricada a orientação governamental de um Estado em relação a determinados governos, regiões, estruturas e conjunturas específicas, assim como se entende que se configura a própria política externa (Vizentini, 1999) interação conflitiva e, ao mesmo tempo, cooperativa, que constitui a política internacional.

Tais afirmações, que remetem aos espaços de circulação e de produção do discurso presidencial, em encontros entre chefes de Estado ou de governo, permite-nos também dizer que não é possível definir fronteiras delineadas e acabadas entre territórios demarcados, quando se trata, principalmente, do discurso presidencial em seu viés internacional. Isto porque diversos setores de atuação humana de vários países compõem esses encontros de discussão. Nesta direção, os espaços públicos e privados das políticas dos países, com efeito, fundam-se, e as práticas discursivas caracterizam-se por serem fluidas e por atuarem como articulações de força, as quais precisam se ajustar a comunidades/grupos, que apresentam, ao mesmo tempo, interesses comuns e singulares.

Vale relembrar o que expusemos às páginas 76-77 deste trabalho a respeito de o discurso político (na acepção de política macro), em um espaço nacional, atravessar os demais setores de atuação humana (midiático, econômico etc.), de modo que interesses e desafios se sobreponham e se articulem em um constante diálogo de formação e de transformação em termos de discussão e de decisão.

Se assim ocorre com o discurso político de modo geral, compreendemos ser o domínio internacional da política um campo acentuado de metamorfoses constantes do discurso, por este receber influência tanto dos vários setores internos de um país quanto das "relações de obediência, influência ou supremacia existentes entre diferentes Estados" (ALBUQUERQUE, 2005) e, também, por esses espaços de produção discursiva estarem 
passando por mudanças relativas no que concerne à globalização da informação, obtida pelos avanços tecnológicos da mídia.

A respeito de o setor político intervir em outros setores de atuação humana e, ao mesmo tempo, ser influenciado por estes últimos, destacamos a afirmação de Charaudeau (2006, p.29-30), para quem esse diálogo se torna mais complexo, quando se observa o jogo político em uma dimensão internacional:

[...] esse setor torna-se cada vez mais complexo diante da influência crescente de instâncias supranacionais, que se encontram, elas próprias, em uma relação de dependência e de autonomia quanto às instâncias nacionais. De dependência, posto que são formadas por representantes de vários Estados (União Européia, ONU, GATT e depois OMC, FMI). De autonomia, na medida em que elas próprias agem como instituições que têm poder de controle sobre os Estados, frequentemente com a ajuda de especialistas ou de tecnocratas ditos independentes. Além disso, as instâncias nacionais sofrem pressão regional dos que se encontram entre o desejo de marcar sua especificidade ante o Estado, e o de serem diretamente reconhecidos pelas instâncias supranacionais por meio de uma recomposição regional que supere os Estados. Isso sem contar a emergência de uma nova militância que tenta regular o mundo do comércio e do direito internacional (Anistia internacional, Médicos sem Fronteiras e diversos movimentos anti ou pró-globalização).

Tal afirmação aponta, principalmente, para a configuração de relações de força estabelecidas na política em sua dimensão internacional. A fim de ilustrarmos essa relação estreita e complexa existente entre instâncias internacionais, indicamos a visita feita pelo expresidente da República Luis Inácio Lula da Silva a China, em maio de 2004. Neste encontro, Lula foi acompanhado de uma comitiva de ministros, governadores e quatrocentos empresários. Fato é que, situações interacionais como esta - em que setores como o jurídico, o econômico, o midiático e o político do Brasil interagem uns com os outros de modo interdependente e dialogam com os dos chineses - envolvem esforços por parte dos elaboradores do discurso presidencial e de quem o profere, primeiramente, para compreenderem o modelo de evento em que estão inseridos e, por conseguinte, tentarem prever a dimensão que pode ser dada à fala do presidente da República.

Além do mais, conseguir boas relações com a China - atualmente, significativa potência econômica - faz que o Brasil, em termos econômicos, possa, por exemplo, fortalecer-se nas negociações da OMC (Organização Mundial do Comércio). Tais implicações indicam o importante papel dos pronunciamentos do presidente da República e, 
assim, de seu planejamento, uma vez que um resultado positivo ou negativo de um encontro influencia outras situações de negociação.

Ainda a respeito das relações de força instaurada na política em sua dimensão internacional, pode-se afirmar que não há um poder central. Seguindo nesta direção, Tupynambá (2010) assinala que não existe “um Estado dos Estados” (op. cit., p. 101), isto é, não há um país que foi, oficialmente, legitimado para exercer poder sobre os demais, sancioná-los e falar em nome de todos. O que há é hegemonia entre diferentes países, constituída e reconstituída historicamente. Isto quer dizer que cada qual busca seus interesses e tenta projetar-se de modo a conquistar um lugar de prestígio em situações interativas, nas quais as características dos Estados-agentes alteram-se em termos da força (política, econômica etc.), que cada um representa no cenário internacional.

Dessa maneira, na política internacional, não se pode negar que existem regras especificas que estão em jogo e, principalmente, relações de poder entre os políticos, a partir das quais comportamentos discursivos são influenciados. Nesta acepção, ao mesmo tempo em que atinge um escopo social regulamentado por normas de uma sociedade, como a brasileira, transpassa-se esse espaço de regulamentação, alcançando um conjunto de Estados ou grupos, os quais nem sempre coadunam com os acordos internos existentes em um país.

Entendemos que criar condições de negociações em situações como essas, implica jogar com o que é comum entre as partes - crenças, culturas, interesses políticos e comerciais etc. Neste sentido, é preciso aproximar de algum modo, buscar interesses e propor ações que se ajustem às regulamentações próprias de cada país e que estejam de acordo com os projetos políticos nacionais.

Convém ainda destacar, em consonância com Chilton (2004), que o âmbito global da política envolve tipos de interação que estão, cada vez mais, aumentando em termos de complexidade e de diversidade. A quantidade de informação e de pessoas envolvidas influencia de modo significativo na língua e no discurso. Isto ocorre, principalmente, a partir do século XXI, em que o discurso político se insere em um cenário marcado pela mudança em termos de criação de interações políticas específicas e da emancipação de tecnologias, como a internet, que fizeram as práticas discursivas ficarem evidenciadas, devendo ser explicadas para auditórios múltiplos.

As questões levantadas por Chilton (2004) merecem a devida atenção, justamente por conta de alguns comportamentos marcados historicamente nas relações entre Estados. Nosso 
conhecimento de mundo permite-nos afirmar que os países costumam buscar seus interesses não só por meio do discurso, mas também por meio da imposição pela força (física, armada). Com efeito, parece-nos coerente dizer que, atualmente, este último procedimento passa por transformações pelo fato de ele estar sob o julgamento de uma sociedade globalizada, e as informações terem ganhado ampla dimensão, de maneira que decisões políticas são questionadas e precisam, por vezes, ser justificadas.

De modo geral, as comunidades possuem instituições que limitam e penalizam o uso desse tipo de força. No âmbito internacional, assim também ocorre, uma vez que existem algumas normas e princípios inscritos no Direito Internacional Público, o qual consiste de um sistema normativo (direitos e deveres) que rege as relações entre Estados. Neste campo de atuação, estão as Organizações Internacionais, como é o caso da ONU, a qual inclui em seus objetivos o desenvolvimento dos direitos internacionais, cujos tópicos voltam-se para os direitos humanos, a criminalidade internacional, o uso da força ${ }^{41}$ etc.

$\mathrm{Na}$ Carta da ONU, que consiste de um documento de fundação dessa organização, informa-se a respeito de seus ideais e de seus propostos ${ }^{42}$. Observemos o que se diz em uma parte de seu preâmbulo:

Nós, os povos das Nações Unidas, resolvidos a preservar as gerações vindouras do flagelo da guerra, que, por duas vezes no espaço da nossa vida, trouxe sofrimentos indizíveis à humanidade, e a reafirmar a fé nos direitos fundamentais do homem, na dignidade e no valor do ser humano, na igualdade de direitos dos homens e das mulheres, assim como das nações grandes e pequenas, e a estabelecer condições sob as quais a justiça e o respeito às obrigações decorrentes de tratados e de outras fontes de direito internacional possam ser mantidos, e a promover o progresso social e melhores condições de vida dentro de uma liberdade mais ampla.

Nessa citação, podemos observar que há menção às obrigações advindas de tratados e dos princípios do direito internacional. Embora haja acordos ou normas internacionais como essas, que visam à organização e à orientação de condutas dos atores dos Estados nacionais, há de se considerar que nem sempre tais regulamentações são atendidas, principalmente, no que se refere à questão da guerra e da paz. De todo modo, temos que o papel do discurso

\footnotetext{
${ }^{41}$ Informações obtidas no seguinte endereço eletrônico: http://www.onu.org.br/a-onu-em-acao/a-onu-e-o-direitointernacional/. Acesso em 02 mar. 2013.

${ }^{42}$ Disponível em: http://www.onu.org.br/conheca-a-onu/. Acesso em 01 jan. 2013.
} 
presidencial direcionado a líderes estatais torna-se significativo, uma vez que é por meio dele que se pode chegar a acordos entre países e se distanciar, quando bem formulado, de situações de conflito.

A partir do que expusemos, podemos afirmar que os discursos presidenciais determinam-se também pelos entornos sociais, políticos e históricos. Ainda, concebemos que existem finalidades e expectativas interacionais específicas nas situações políticas, em que um chefe de Estado profere um discurso a outros líderes políticos mundiais.

Em razão de tais especificidades estarem relacionadas tanto às próprias características da política internacional quanto aos posicionamentos dos políticos que compõem a representatividade de um país, julgamos significativo considerar a passagem de um grupo governante a outro e o momento em que ela ocorre como condições que afetam os políticos de modo geral (e, consecutivamente, seus discursos) e criam expectativas e especulações por parte de alguns auditórios acerca de certos credenciamentos, em termos de se saber com quem se está jogando e de que modo será conduzido o jogo.

Nesse viés, julgamos importante discorrer a respeito da caracterização do governo Lula e, em específico, de sua política externa. Isto porque entendemos que os discursos presidenciais desse político - direcionados a chefes de Estado e de governo, entre outros imprimem toda a especificidade da política internacional e, concomitantemente, apresentam particularidades, em razão de ter havido interesses, crenças e valores do grupo que compunham o governo brasileiro da época. Salientamos que não temos por objetivo o aprofundamento de questões voltadas para as ciências políticas, mas sim a utilização de algumas informações que nos forneçam subsídios para a análise de nosso corpus. Tal discussão é apresentada a seguir.

\subsection{Estratégia política global do governo Lula e discurso presidencial da mudança}

Vimos que a prática discursiva caracteriza-se por sua dimensão também contextual (cognitivo, situacional), que a influencia e delineia. Nela e por ela, universos discursivos vêm sendo construídos no campo político como ação estratégica de busca pelo poder. Se assim ocorre nas diversas tentativas feitas, por exemplo, por candidatos que pleiteiam um cargo de chefe de Estado, como muito se nota nas campanhas políticas televisivas, quando se trata de 
política internacional, outros elementos entram em cena e dialogam com os discursos dos políticos, tal como discutimos anteriormente.

Consideramos, portanto, que é a partir do exame, não exaustivo, da configuração e das conjunturas diversas de um espaço político marcado por mudanças significativas, em termos de criação de novas tecnologias, de crises econômico-sociais, de posturas ideológicas etc., que nosso corpus será melhor compreendido, uma vez que separar o discurso de sua condição específica de produção corresponde a desconsiderar a motivação que a ele deu corpo; apartálo disto não se sustenta quando se tem por objetivo tratá-lo como prática modificadora de meios políticos e sociais.

A partir disso, primeiramente, discorremos sobre o momento em que Lula ascende ao cargo de chefe de Estado; uma história de legitimação política peculiar no Brasil - de torneiro mecânico a presidente da República. Quando assume este cargo, ele se depara com um legado (1995-2002) deixado pelo então ex-presidente Fernando Henrique Cardoso (FHC) - "o tipo de político dos anos 1990: jovial, contra a 'política tradicional', poliglota e intelectualizado" (VIZENTINI, 2008, p.92) - e com as especificidades do percurso histórico deste político que são, naturalmente, relacionadas ao de Lula de maneira a levar a certos julgamentos e incertezas em um primeiro momento.

Além do mais, Lula apresentou propostas - enquanto candidato à presidência da República - pelas quais convenceu a maioria dos brasileiros da necessidade de comportamentos novos em face, principalmente, das situações sociais de desigualdade as quais compunham o cenário do Brasil.

Quando eleito, no exórdio de seu primeiro pronunciamento feito no Congresso Nacional, direcionado à sociedade brasileira e a alguns chefes de Estado e de governo, no dia primeiro de janeiro de 2003, ele retoma e enfatiza tal objetivo de mudança. Tendo em vista que esta primeira manifestação discursiva de Lula como presidente da República é extremamente significativa, por ela integrar uma proposta política assumida em público, divulgada na mídia nacional e internacional, observemos alguns segmentos (Anexo 01), atentando-nos às partes destacadas em itálico: 
(3)

05 Excelentíssimos senhores chefes de Estado e de Governo; visitantes e chefes das missões especiais estrangeiras; excelentíssimo senhor presidente do Congresso Nacional, Senador Ramez Tebet; Excelentíssimo senhor vice-presidente da República, José Alencar; excelentíssimo senhor presidente da Câmara dos Deputados, deputado Efraim Morais; excelentíssimo senhor presidente do Supremo

10 Tribunal Federal, ministro Marco Aurélio Mendes de Faria Mello; senhoras e senhores ministros e ministras de Estado; senhoras e senhores parlamentares, senhoras e senhores presentes a este ato de posse.

"Mudança": esta é a palavra-chave, esta foi a grande mensagem da sociedade brasileira nas eleições de outubro. A esperança, finalmente, venceu o medo e a 15 sociedade brasileira decidiu que estava na hora de trilhar novos caminhos.

Diante do esgotamento de um modelo que, em vez de gerar crescimento, produziu estagnação, desemprego e fome; diante do fracasso de uma cultura do individualismo, do egoísmo, da indiferença perante o próximo, da desintegração das famílias e das comunidades, diante das ameaças à soberania nacional, da

20 precariedade avassaladora da segurança pública, do desrespeito aos mais velhos e do desalento dos mais jovens; diante do impasse econômico, social e moral do país, a sociedade brasileira escolheu mudar e começou, ela mesma, a promover a mudança necessária. Foi para isso que o povo brasileiro me elegeu Presidente da República: para mudar.

[...] O Brasil é um país imenso, um continente de alta complexidade humana, ecológica e social, com quase 175 milhões de habitantes. Não podemos deixá-lo seguir à deriva, ao sabor dos ventos, carente de um verdadeiro projeto de desenvolvimento nacional e de um planejamento, de fato, estratégico. Se queremos transformá-lo, a fim de vivermos em uma Nação em que todos possam andar de cabeça erguida, teremos de exercer quotidianamente duas virtudes: a paciência e a perseverança.

No discurso pronunciado pelo então presidente da República, pode-se dizer que se jogou com a categorização negativa de um Brasil Velho (de FHC) e a de um novo, isto é, promoveu-se uma possível recategorização do país, em que a proposta de uma sociedade ideal esteve presente. Este procedimento ocorreu, primeiramente, por meio de formulações linguísticas ("Diante do esgotamento de um modelo que, em vez de gerar crescimento, produziu estagnação, desemprego e fome; diante do fracasso de uma cultura do individualismo, do egoísmo, da indiferença perante o próximo, da desintegração das famílias e das comunidades", linhas 16-19), pelas quais determinadas informações foram evidenciadas, sustentando a ideia de uma sociedade que se encontrava sob o comando de um governo o qual a deixou à deriva de suas necessidades econômicas e sociais.

Essa situação social constituída no discurso pode ser associada, indiretamente, às posturas adotadas pelo governo anterior e, concomitantemente, pelo seu ex-governante, de maneira a atribuir-lhe avaliações extremamente negativas, uma vez que não se espera de um 
chefe de Estado "fracasso, individualismo, egoísmo, indiferença" (linhas 17-18), muito menos que ele não tenha visão estratégica de um projeto de desenvolvimento nacional.

Seguindo nessa direção, temos que a formulação indefinida "um modelo que, em vez de gerar crescimento, produziu estagnação, desemprego e fome" (linhas 16-17) opera junto e alicerçada a outras informações, no desenvolvimento do discurso, como orientadores dessas categorizações avaliativas, de tal modo que se torna possível orientar o auditório a criar associações que o conduzam a construir determinado sentido sobre o governo antecessor.

Tal procedimento recaiu sobre uma acusação indireta, distanciando o orador de qualquer posicionamento explícito contra determinados políticos. Para Aquino (2005, p.112): "Se utilizada de modo direto, a acusação fragiliza, enfraquece o locutor; elaborada por meio de implícitos, exime de culpabilidade quem a formula”. Assim é que Lula fortaleceu seu posicionamento, ao não citar nomes e ao encaminhar o discurso, de modo a fazer que os interlocutores fossem cúmplices do sentido proposto.

Ainda em relação ao discurso de posse, podemos examinar que foi no tecido discursivo que se negociou o sentido da avaliação pejorativa da situação do Brasil no governo FHC. Dá-se a conhecer, no processo de referenciação, o percurso selecionado para validar a proposta de Lula, a partir do momento em que o objeto de discurso Brasil foi sendo categorizado e recategorizado, em um jogo de seleções lexicais (às linhas 38-44), pelo qual se evidenciou como estava (linhas 37-41)

[...] O Brasil é um país imenso, um continente de alta complexidade humana, ecológica e social, com quase 175 milhões de habitantes. Não podemos deixá-lo 40 seguir à deriva, ao sabor dos ventos, carente de um verdadeiro projeto de desenvolvimento nacional e de um planejamento, de fato, estratégico.

e em que ele se tornaria no governo Lula (linhas 41-44):

Se queremos transformá-lo, a fim de vivermos em uma Nação em que todos possam andar de cabeça erguida, teremos de exercer quotidianamente duas virtudes: a paciência e a perseverança.

O exame desses segmentos contribui para que compreendamos o entrelace apresentado entre o Brasil-País de FHC e o Brasil-Nação de Lula (em que todos poderiam andar de cabeça erguida). Entendemos que esse procedimento implica a articulação de forças existente na 
política nacional, em que a oposição, ao se tornar governo, agiu, a fim de validar um posicionamento partidário e de se ajustar a um momento, entendido como histórico por conta do percurso político do ex-presidente.

Salientamos, ainda, que a proposta de mudança também pode ser observada em outro segmento do discurso de posse do ex-presidente Lula, quando ele apresentou o projeto Fome Zero (Anexo 01):

(4)

[...] Enquanto houver um irmão brasileiro ou uma irmã brasileira passando fome, teremos motivo de sobra para nos cobrirmos de vergonha.

Por isso, defini entre as prioridade de meu governo um programa de segurança alimentar que leva o nome de "Fome Zero". Como disse em meu primeiro pronunciamento após a eleição, se, ao final do meu mandato, todos os brasileiros tiverem a possibilidade de tomar café da manhã, almoçar e jantar, terei cumprido a missão da minha vida.

A formulação "Zero" modifica a palavra "Fome" de modo a encaminhar, novamente, um olhar sobre a possibilidade de uma sociedade ideal e, consecutivamente, de um enunciador visionário, portanto, líder, que assume os direitos humanos em seu discurso e se constrói como agente promissor de mudanças positivas.

Relacionamos esse procedimento de Lula aos pressupostos de Charteris-Black (2007) a respeito da liderança política. O autor afirma que um líder político busca direcionar um grupo, de maneira a chegar a um acordo ou a alcançar uma meta. $\mathrm{O}$ estudioso ainda assinala que existem dois fatores significativos para compreender um líder político e, também, seu estilo. O primeiro consiste nos ideais apresentados em seus discursos - que levam à imagem de um visionário - e nos valores assumidos. O segundo remete-se à figura carismática construída em diversas situações da vida política, estreitamente relacionada ao próprio carisma, às questões de cunho religioso e aos efeitos de contar uma história alinhada às especificidades de um encontro e às expectativas dos interlocutores.

Ainda salientamos que muitos estudos detiveram-se à análise de líderes. Entre eles ${ }^{43}$, há os que partiram do pressuposto de que, para liderar com supremacia, é preciso que o

${ }^{43}$ Charteris-Black (2007) cita, entre outros: STOGDILL, R.M. (1948). Personal factors associated with leadership: A survey of the literature, Journal of Psychology, Nova Iorque, 25, p. 35-71. 
indivíduo tenha inteligência, perspicácia, responsabilidade, iniciativa, sociabilidade, viva em estado de alerta, entre outras características. Já em outras pesquisas, privilegiaram-se as condições específicas de produção de maneira a não se preocupar exclusivamente com traços peculiares e inerentes a um estereótipo de líder.

Seguindo nessa direção, levando-se em conta, sobretudo, as características do encontro - discurso presidencial de posse dirigido a brasileiros e a estrangeiros - por entendermos que o topo da liderança política, em termos de representatividade, corresponde ao lugar ocupado por um presidente da República, podemos dizer que, nos segmentos (3) e (4) do anexo 01, observa-se a criação de uma representação social que busca promover a imagem pública de um político como líder do povo (posicionamento partidário) e líder de seu país, uma vez que os valores e os ideais assumidos em seu pronunciamento se ajustavam aos interesses de boa parte da população brasileira e poderiam direcioná-la a acreditar e a confiar no locutor. Não se tratou apenas de promover credibilidade no dia de sua posse, o locutor encaminhou um discurso, de modo a tornar possível que se criasse esperança e uma sensação de segurança perante situações as quais requeriam mudanças sociais; mais um procedimento discursivo condizente à atitude de um líder político, conforme os estudos de Charteris-Black (2007).

Consideramos que a estratégia discursiva baseada na mudança consiste de um tópico significativo para os estudos do discurso político de modo geral, sobretudo, do presidencial, pois pode despertar esperança, confiabilidade ou mesmo receio. Há ainda de se considerar que essa estratégia não foi empregada pela primeira vez por um presidente da República em situação de posse. Esse procedimento foi já utilizado por Fernando Collor de Melo, ex-chefe do Estado brasileiro (1990-1992), que prometeu mudar de postura em relação ao governo anterior de José Sarney, como, por exemplo, ao pretender reaproximar o Brasil dos Estados Unidos.

Embora levemos em consideração que tal estratégia já tenha sido utilizada por outro político, acreditamos que ela mereça atenção em nosso trabalho, por ser o próprio Lula considerado um símbolo de novidade, que pode gerar expectativa acentuada, quando se relaciona, de início, o pronunciamento de posse a seu orador. Nesta direção, ao tomar a palavra publicamente em uma situação institucional, que o legitima como ator que detém o poder de decisão de questões de ordem política, o orador alcança auditórios diversos e pode suscitar, neles, reações específicas, uma vez que a compreensão de seu discurso concorre com os modelos mentais diversos a respeito do novo governante e do Brasil. 
Nessa direção, se, por um lado, o discurso é direcionado à população brasileira de modo geral, por outro, atinge também um auditório maior, os políticos do exterior, em razão da presença de alguns chefes de Estado e de Governo e da própria característica de amplo alcance do discurso presidencial. Neste viés, entendemos que já se iniciava a busca por alcançar uma imagem positiva de um Estado e de seu novo governo no cenário internacional.

Assim é que o exame do discurso de posse possibilita-nos conhecer o caminho inicial utilizado para se dar legitimidade a um governo novo e, consecutivamente, para se obter certa representatividade do país no exterior. Temos que o procedimento discursivo recai sobre a tentativa de se criar uma nova noção a respeito de um governante, a partir de uma relação de um modelo ideal de conduta e seu antimodelo. É neste viés que o pronunciamento se apoia, permitindo aos interlocutores conhecerem tal dissociação e criarem identificação com os valores atribuídos ao governo de Lula.

Além disso, Lula assumiu para si a proposta de mudança em relação à política externa, tendo-a como mais uma promessa de desenvolvimento nacional. Observemos outro segmento de seu discurso de posse, em 2003 (anexo 01):

(5)

Esta nação que se criou sob o céu tropical tem que dizer a que veio; internamente, fazendo justiça à luta pela sobrevivência em que seus filhos se acham engajados; externamente, afirmando a sua presença soberana e criativa no mundo.

210 Nossa política externa refletirá também os anseios de mudança que se expressaram nas ruas. No meu governo, a ação diplomática do Brasil estará orientada por uma perspectiva humanista e será, antes de tudo, um instrumento do desenvolvimento nacional. Por meio do comércio exterior, da capacitação de tecnologias avançadas, 215 e da busca de investimentos produtivos, o relacionamento externo do Brasil deverá contribuir para a melhoria das condições de vida da mulher e do homem brasileiros, elevando os níveis de renda e gerando empregos dignos.

Observa-se que Lula não apenas falou em mudanças no âmbito interno do país, mas também assinalou uma nova postura a respeito da política externa (linhas 210-215). Sobre este procedimento, temos que o surgimento de um novo governo também pode suscitar questionamentos a respeito de rupturas ou de continuidade na condução de alguns tópicos como o da política externa. A questão é que esta expectativa quanto à mudança foi acentuada por vir acompanhada por esse pronunciamento público do ex-presidente. Tal político por si só já confere ao seu discurso certas particularidades, caso este seja relacionado aos valores 
atribuídos à imagem pública de quem o pronuncia. Assim é que as mesmas seleções lexicais podem produzir sentidos variados conforme a pessoa que as assume.

Ao mencionarmos a respeito desta relação discurso e a imagem presumida de seu orador, coadunamos com a seguinte afirmação de Perelman e Olbrechts-Tyteca (2002 [1958], p. 362): "De fato, o enunciado não é o mesmo, quando emana deste ou daquele outro autor, ele muda de significado; não há simples transferência de valores, mas reinterpretação num contexto novo, fornecido pelo que se sabe do autor presumido".

Além do mais, ocorre que o discurso de posse é conduzido, promovendo um sentido de a população compartilhar a tese enunciada, isto é, o posicionamento de Lula é apresentado como uma atitude que atende a um pedido da sociedade, como se nota às linhas 210-211 (Anexo 01): "Nossa política externa refletirá também os anseios de mudança que se expressaram nas ruas". Assim, ao reforçar a ideia de atuar como um governante que preza pela opinião e pelos anseios da população, mais uma vez, o orador alicerça sua imagem à de um representante do povo e põe em evidência o credenciamento e a legitimidade alcançados para agir na política externa.

Interessa-nos, ainda, examinar alguns segmentos do discurso de posse do expresidente, proferido no planalto, em primeiro de janeiro de 2007 (anexo 02), que dão a conhecer como o ex-presidente encaminha um olhar específico sobre seus quatro anos de governo:

(6)

$5 \quad$ Meus queridos brasileiros e brasileiras,

É com muita emoção que eu subo a este Parlatório para conversar um pouco com vocês. Hoje é para mim um dia de profunda emoção. Primeiro, porque ser Presidente da República do meu País, eu recebo isso como uma bênção de Deus, porque eu digo sempre que chegar onde eu cheguei, saindo de onde eu saí, eu só

10 posso dizer que existe um ser superior que decide os destinos de cada um de nós e, por isso, eu estou aqui.

[...] Em momentos muito difíceis, quando alguns imaginavam que o jogo tinha 15 acabado, o povo entrava em campo e dizia claramente: nós construímos a democracia deste País e nós vamos sustentar a democracia deste País, custe o que custar, doa a quem doer.

[...]Quero dizer a vocês que esses próximos quatro anos serão quatro anos de muito

95 trabalho. E vamos trabalhar mais do que trabalhamos no primeiro, porque já conhecemos os caminhos das pedras, já conhecemos onde é que as coisas, muitas vezes, emperram. E nós, que sabemos que a economia brasileira precisa crescer, gerar empregos e distribuição de renda, sabemos que precisamos destravar o País para que ele possa crescer, para que ele possa gerar a quantidade de empregos, e 
100 empregos formais, com carteira assinada, porque aí, sim, o trabalhador brasileiro vai estar mais qualificado e vivendo um pouco melhor.

Ao observarmos o exemplo (6), depreendemos um discurso que se distanciou da formalidade utilizada no discurso de posse de 2003, pronunciado no Congresso Nacional. Referindo-se ao seu pronunciamento como uma conversa ("É com muita emoção que eu subo a este Parlatório para conversar um pouco com vocês", linhas 6-7), Lula enfatizou, principalmente, a ideia de um governante trabalhador. Utilizando-se da metáfora do percurso, a formulação "os caminhos das pedras" (linha 96) é indicativa de uma justificativa, que pôs em evidência os obstáculos encontrados pelo ex-presidente em seus quatros anos de mandato. Não houve mais a proposta de mudança, e sim a promessa de seguir trabalhando, para que o brasileiro vivesse "um pouco melhor" (linha 101).

Além do mais, a seleção lexical "o jogo" (linha 14) dá-nos a conhecer a maneira como o político conceituou e se posicionou em relação à prática política, isto é, pode-se entender que ele se assumiu como jogador, cujo time correspondia à população brasileira, e apresentou a necessidade de as estratégias utilizadas serem revistas, a fim de fazer que o Brasil crescesse.

Ainda nessa direção, se tomarmos como fator significativo o fato de os últimos anos do mandato de Lula terem sido marcados por denúncias de corrupção, as quais envolviam membros do PT, compreendemos que os adversários do jogo podem ser relacionados aos políticos, entre outros, que se opunham à permanência do então governante. Mais uma vez, portanto, a acusação ocorreu de modo indireto.

Alguns estudiosos do campo da política, como Almeida (2004) e Vaz (2003), referemse aos discursos de Lula como ações que enfatizaram as diferenças entre o governo anterior de Fernando Henrique Cardoso (FHC) e o de Lula. De fato, não se pode negar que a atitude de demarcar rupturas e enfatizar novos posicionamentos foram procedimentos presentes na prática discursiva do ex-presidente da República.

Nessa direção, Vaz (2003, p. 1) assinala que:

Ao encarnar o desejo de mudança, o novo presidente dispôs-se a empreendê-las em todos os ângulos, inclusive o da política externa. Tal disposição traz implícito um juízo crítico (por vezes velado) sobre o desempenho de seu antecessor de forma mais imediata, e também (explicitamente) sobre o modelo de desenvolvimento a que a política externa servia. 
Vizentini (2008) afirma que a eleição de Lula e os procedimentos de seu governo foram vistos, por muitos, com apreensão, uma vez que temiam um comportamento ideológico advindo de um líder despreparado. A respeito disto, ainda conforme esse autor, é interessante observar que a primeira Assembleia Geral da ONU, em que o ex-presidente brasileiro participou e proferiu seu discurso na abertura do encontro, contou com uma participação recorde de líderes. Esta configuração peculiar do auditório presente no evento pode ser entendida como um indício da ampla especulação existente, na época, acerca do novo governante.

Temos que, após vencer as eleições presidenciais, diferentes caminhos foram necessários trilhar, nos quais outros tipos de credenciamentos estavam em jogo em termos de política externa. Tal afirmação respalda-se no pressuposto de Vizentini (1999), para quem, na política externa, existem duas questões importantes: quem a formula e como esta se articula à política interna. Em relação à primeira questão, decisões pertinentes à política externa não estão atreladas apenas ao grupo político do poder, mas por alguns setores hegemônicos deste bloco, os quais têm certos interesses.

Além do mais, é possível afirmar que algumas alterações de ordem global permitiram uma busca mais acentuada por participação político-econômica internacional a partir de mecanismos que promovessem aproximação e distanciamento entre países e grupos internacionais, em razão de o alcance de um poder dominante, no espaço internacional, passar a ser atrelado à força política, resultante do alcance de identificação com públicos heterogêneos em termos de interesses econômicos, políticos e sociais. Nesta acepção, temos que o discurso presidencial de Lula somou-se às necessidades de um jogo de cooperação e de conflito de um novo cenário global. As especificidades dessas ações, que acreditamos terem dado contornos diferenciados aos pronunciamentos do ex-presidente da República, são apresentadas a seguir.

\subsection{Dimensão da política externa do governo Lula}

\subsubsection{Prática discursiva voltada ao multilateralismo e às parcerias bilaterais}

O Brasil, em sua história, passou pela hegemonia portuguesa, posteriormente, pela inglesa e, gradativamente, no século XX, pela influência norte-americana, caracterizada por uma nova fase. Destacamos tais relações por elas estarem imbricadas na construção da 
imagem de um país em termos também de espaço nacional, de alianças específicas externas e, assim, de posicionamentos e decisões políticas de âmbito global. A respeito disto, Vizentini (1999, p.135) afirma que:

\begin{abstract}
Durante a fase colonial, o Brasil encontrava-se integrado ao mercantilismo português. Com o advento do processo de emancipação, nossa dependência assimétrica transferiu-se para a órbita do livre comércio hegemonizado pela Inglaterra. Paralelamente, acentuou-se outra dimensão das relações internacionais do Brasil: a dos problemas regionais vinculados à construção do espaço geopolítico e nacional brasileiro, também enfocada como "questão de fronteiras". Nesse contexto, a rivalidade com a Argentina fazia parte de uma relação simétrica, herdada dos antagonismos coloniais, a qual se caracterizou como um campo de relativa autonomia para o exercício de nossa diplomacia.
\end{abstract}

O que ocorria, de fato, era que o contexto situacional político em que Lula se encontrava era produto de uma crise da terceira hegemonia mundial, relacionada ao poder norte-americano, iniciada, de modo explícito, na era de Janio Quadros e de Goulart. Já naquele momento, observaram a necessidade de atuar no cenário mundial, a fim de alcançar independência dos Estados Unidos, encontrando, no multilateralismo, o caminho para tal resultado. Isto, para Vizentini (1999), estendeu-se até o governo Lula, embora não possamos deixar de lembrar que se buscou reaproximar Brasil e Estados Unidos nos dois anos de mandato do ex-presidente Fernando Collor de Melo.

Outra alteração, em termos de relações políticas internacionais, correspondeu ao fato de, antes mesmo de Lula se tornar presidente da República, o contexto histórico da política global já ter apresentado, em 2001, um acontecimento, que modificou de maneira significativa o cenário internacional: os ataques de 11 de setembro. A partir desse momento, os Estados Unidos passaram a privilegiar questões relacionadas à segurança e, isto, entre outras questões, resultou na mudança das tendências internacionais, tendo em vista que o cenário se tornou mais acessível para a constituição de um poder multipolar. A respeito destas mudanças que vão reconfigurando o contexto político internacional, em termos de relações de força, tem-se que "as perspectivas de construção de uma ordem mundial estável e hegemonizada pelos Estados Unidos parecem hoje menos prováveis que há dez anos" (VIZENTINI, 2008, p. 103).

Entendemos que tais alterações, no âmbito internacional, alicerçaram alguns procedimentos do governo Lula em sua política externa, principalmente, em relação à busca 
de mais participação na política global e, consecutivamente, mais poder por meio do multilateralismo. A respeito desta estratégia, de acordo com as informações divulgadas pelo Itamaraty, apresentadas no caderno de resumo executivo disponível em seu site, a política externa dos dois mandatos do governo Lula foi direcionada, levando-se em conta os seguintes eixos:

- A América do Sul é o eixo prioritário de nossa política externa, tendo o Mercado Comum do Sul (Mercosul) como núcleo central. Para este continente foram dedicados esforços necessários no sentido de avançar no processo de integração.

- A África Ocidental, incluindo os arquipélagos de Cabo Verde e São Tomé e Príncipe, representa uma antiga fronteira, que havia sido esquecida, mas cujos laços precisam ser reatados.

- A Ásia, novo centro dinâmico da economia mundial, é espaço essencial para a participação do Brasil no mercado global.

- Europa e América do Norte, áreas tradicionais de vinculação política, econômica e cultural, permanecem como parceiros relevantes do Brasil, em particular no esforço de reforma da governança política e econômica global.

Como vimos (Cf. p.88-89), em relação à política em sua dimensão internacional, existem necessidades voltadas à busca de parcerias (bilaterais e multilaterais) e de promoção de um Estado, a fim que se reconheça força econômica e política. Ao agirem em prol desses interesses, por vezes, os políticos deparam-se com comunidades, cujas regulamentações e sistemas de crenças, de valores etc. nem sempre estão alinhados às conjunturas de seu grupo. Tais afirmações podem ser consideradas como fatores que permearam de modo acentuado as práticas discursivas da política externa do governo Lula, principalmente, em razão de a proposta governamental ter sido baseada no multilateralismo, tal como é evidenciado na citação acima.

Nessa direção, tem-se que o dizer do ex-presidente da República, no campo internacional, ora foi direcionado para grupos heterogêneos, ora para específicos. Por tal razão, entendemos ter havido a necessidade de os pronunciamentos - por detrás dos quais se visou à autopromoção de um Estado, entre outros objetivos, a partir de acordos com países diversos - estarem condizentes às propostas governamentais e às características específicas de seus públicos e, por conseguinte, o discurso ${ }^{44}$ dever ser monitorado em favor do reconhecimento pretendido.

\footnotetext{
${ }^{44}$ Discurso, pronunciamento e dizer foram utilizados como sinônimos.
} 
Além do mais, o fato de selecionar um país como parceiro, em vez de outro, já implica certas elaborações de ordem discursiva, bem como pode ser um caminho para lidar com os embates de força da política internacional, uma vez que um Estado, ao se incluir como parceiro de outro, pode fortalecer sua imagem, se houver associação entre as características divulgadas de um e do outro. Nesta direção, evidenciar interesses comuns consiste de um modo de fazer que alguns políticos do exterior reconheçam tais semelhanças e, assim, aceitem um determinado país como membro de seu grupo, promovendo aproximação entre partes e cooperação de diversas ordens.

Como discutimos, o presidente da República representa um país, que precisa fazer parcerias ou se incluir como membro de certos grupos, a fim de obter apoio e de garantir a participação no cenário internacional. Neste viés, entendemos que se tende a construir discursivamente certas entidades (como o Brasil e sua relação com outro país), para assegurar participação na política internacional, por meio de um processo dinâmico de associações múltiplas entre os agentes da situação política.

Dessa maneira, para obter força internacional, o investimento recai, por vezes, sobre a ligação entre Estados, ou mesmo da inclusão de um país em um grupo já formado, cuja imagem de prestígio e de poder poderá ser atrelado ao novo integrante. Nesta acepção, consideramos que o jogo político entre chefes de Estados e outros agentes que participam das reuniões da política internacional é formado por uma configuração - na qual existem tipos de ligação de sucessão - em que a proposta de expansão comercial e política faz parte. Assim, a prática discursiva é conduzida pelo viés da cooperação, a partir de uma ideia de causa, efeito e consequência.

Seguindo nessa direção, a política internacional implica a ação conjunta entre Estados. Os discursos presidenciais, neste viés, agem também como estratégias de correlação de imagens interestatais, evidenciando informações pertinentes às conjunturas específicas de uma comunidade repleta de antagonismos políticos e valores em formação e em transformação. Trata-se, portanto, do poder político de um Estado construído, também, por meio de alianças estratégicas.

Já se sabe que as práticas políticas da linguagem correspondem a coproduções de sentido, pelas quais ações são validadas por um processo dinâmico, no qual estão envolvidos vários agentes. O poder também influi nessas trocas e age de modos diversos, conforme as instituições que a ele recorrem. No âmbito internacional, os pronunciamentos podem ser entendidos como ações em exercício pela busca de um poder específico, obtido, em boa parte 
das vezes, por meio de negociações em espaços caracterizados por estarem sob os olhos de milhões de pessoas de diversos países.

Em vista disso, o discurso torna-se elemento essencial para a obtenção um poder que implica acordos de várias ordens. Entre eles, temos que o lugar que um Estado assume na política internacional deve-se aos acordos que seus governantes obtêm, tal como é o caso de conseguir uma cadeira permanente no Conselho de Segurança da Organização das Nações Unidas (ONU), ou mesmo, de formar alianças com vários países, para descentralizar o poder de outros e criar condições de negociações, tal como salientamos.

A respeito dos procedimentos do governo Lula, para se buscarem esses acordos de ordem internacional, Vizentini (2008), ao analisar o primeiro mandato desse político, assinala que sua política externa foi caracterizada por três dimensões: uma econômica, uma política e uma agenda social. Em relação à primeira, o autor a define como realista; era necessário manter os canais de negociação com o primeiro mundo, a fim de ganhar recursos, como investimentos e tecnologia, negociar também a dívida externa, para validar a imagem de um governo disposto a honrar com seus compromissos internacionais.

Esse estudioso (op. cit.) considera que a dimensão política representou um campo para o reforço dos interesses nacionais e de um verdadeiro protagonismo; a intenção foi a de desenvolver uma diplomacia ativa e afirmativa. A agenda social, por sua vez, ligada a um projeto governamental interno de Lula, teve participação significativa no espaço político internacional. Os projetos sociais do ex-presidente, inseridos em sua agenda, podem ser considerados, ainda conforme Vizentini (op. cit.), como uma resposta à necessidade de lidar com algumas assimetrias no âmbito da globalização.

Ainda a respeito desse último fator, a agenda social, o autor também afirma que a campanha contra a fome indica um modelo econômico-social alternativo, em resposta à crise da globalização neoliberal. Nas palavras do autor (VIZENTINI, 2003, p.2):

Semelhante ações, como o estímulo ao mercado interno e de poupança, de produção interna e de reforma de componentes nacionais, que impedem uma ação internacional mais qualificada (por exemplo, desigualdade social, desemprego, criminalidade, fraqueza e desordem administrativa e caos fiscal), representam o desenvolvimento deste projeto. A combinação do social, energia, urbano, agrário e políticas produtivas mostrou uma vontade política real. Ao mesmo tempo, o carisma do presidente parecia ter se fundido em sua personalidade aberta e comum as características que o mundo mais admira no Brasil. Isto 
permitiu a Lula sustentar uma intensa agenda internacional como o orador deste projeto ${ }^{45}$.

É interessante observar que a agenda social cumpre papel significativo na diplomacia desse governo e, consecutivamente, está implicada em um projeto maior de busca por credenciamento, em que a prática discursiva se faz presente. Compreendemos que a inserção de projetos sociais internos do país no âmbito internacional possibilitou que se reconhecesse um alinhamento entre as ações internas e as externas do projeto governamental e permitiu que se vizualizasse coerência, que é fator importante para a construção de uma imagem de credibilidade, como já discutimos.

Mais do que isto, é preciso considerar que essas negociações são realizadas por meios discursivos, os quais dialogam com o contexto situacional imediato. Nesta acepção, nas diversas interações no campo da política internacional, o discurso presidencial pode trazer marcas do meio social-político e dessas propostas assumidas pelo grupo do poder. Assim, ao selecionar os projetos sociais em seus pronunciamentos, ativando alguns tópicos, como Justiça Social, e construindo de determinado modo objetos de discurso, o orador posiciona-se e pode fazer que determinados valores sejam reconhecidos, de maneira a credenciar a categorização de um Brasil novo e a possibilitar a reconstrução mental da imagem do país.

Assim, se havia necessidade de buscar novos mercados, temos que muitos deles também se encontravam em situações de desigualdade social, como os países africanos, mas que poderiam se tornar parceiros fortes, caso conseguisssem, juntos, desconcentrar a ordem do comércio global, a qual, como expusemos, passava por transformações, principalmente, em termos de hegemonia, voltada cada vez mais para o poder econômico. Tratava-se, pois, de se aproximar, a partir de características comuns, para ganhar força.

Ainda em relação aos tópicos sobre temas sociais da agenda internacional do governo Lula, salientamos que houve tal direcionamento nos discursos deste político proferidos em Davos, desde janeiro de 2003. Em seu pronunciamento, o ex-presidente destacou a necessidade de ajuda por parte dos "países ricos", a fim de alterar a situação de fome no

\footnotetext{
${ }^{45}$ Tradução livre: Such actions as the stimulus to the internal market and savings, of internal production and the reform of domestic components that impede a more qualified international action (for instance, social inequality, unemployment, crime, weakness and administrative disorder and fiscal chaos), represent the development of this project. The combination of social, energy, urban, agrarian, and productive policies showed a real political will. At the same time, the president's charisma seemed to have merged in his open and ordinary personality the characteristics that the world most admires in Brazil. This has allowed Lula to sustain an intense international agenda as the speaker of this project.
} 
mundo e recebeu apoio dos presidentes Chirac, da França, e Lagos, do Chile (Vigevani e Cepaluni, 2007). Nestes casos, pode-se entender que houve presença de um discurso caracterizado pelo tom peculiar do Partido dos Trabalhadores, como é a questão da apresentação de teses em favor dos mais pobres.

Diante do exposto, entendemos ter havido a necessidade de reconstruir modelos mentais de alguns setores do Brasil e reforçar outros, a fim de reformular a própria imagem deste país como potência econômica, utilizando-se também de um viés humanístico. Além do discurso de posse de Lula, outras ações políticas podem embasar esta afirmação, tais como as estratégias de promover as ações sociais do governo por meio de materiais publicitários, divulgados no país e no exterior, bem como a discussão de tópicos correspondentes à distribuição de renda, à saúde e à educação. Deste modo, o pressuposto é o de que as atividades relacionadas à agenda social trazem à tona certas características, que podem ser associadas ao governo, promovendo-o a partir de alguns valores.

Nessa direção, para tentar garantir participação internacional, o grupo político apoia-se em estratégias também de busca por aprovação a partir de uma representatividade, na qual estão em jogo a construção e a reconstrução de outras imagens. É preciso criar confiança e, para tanto, procede-se, por meio de várias ações, de modo a alterar, se for necessário, um determinado olhar por meio de novos recortes. Assim também ocorreu no governo de FHC, por exemplo, no momento em que este político deixou de usar a formulação "país subdesenvolvido" para se referir ao Brasil e aderiu ao termo América do Sul em substituição da nomeação América Latina.

Acreditamos, portanto, que tais fatores foram primordiais para os rumos da política externa tomados no governo Lula e, consecutivamente, são marcados em seus discursos, como ação sobre o mundo global, de modo a apresentar um entrelace entre os objetivos gerais de um Estado, trilhado historicamente e relacionado a elementos econômicos e sociais do momento, e a ideologia da liderança de um grupo político.

Entre essas preferências estratégicas assumidas na política externa de Lula, estão: a formação do IBSA (Brasil, Índia e África do Sul) em 2003 e a constituição do G20, como cooperação multilateral, composto por um grupo heterogêneo de países em desenvolvimento, entre os quais, alguns exportadores agrícolas, como Brasil, Argentina, China, Índia. Tais parcerias foram escolhidas com intuito de "alterar as relações de forças nas negociações multilaterais" (ALMEIDA, 2012, p.104); entretanto, com o passar do tempo este último 
grupo (G20) foi sendo diluído, por conta das dificuldades encontradas nas negociações da rodada de Doha.

Segundo as declarações de Lula, de seu chanceler e de seus assessores, havia três prioridades do governo: a cadeira permanente no Conselho de Segurança da Organização das Nações Unidas (CSNU), o reforço e a ampliação do MERCOSUL, a conclusão da rodada da Doha das negociações comerciais da OMC. Para Almeida (2012), no governo de Lula, o prestígio do Brasil aumentou de modo significativo a partir, também, de ações publicitárias internas e externas pelas quais se propagavam os programas de inserção social do governo, ação já indicada neste capítulo.

Vigevani e Cepaluni (2007), por sua vez, consideram que boa parte das mudanças do governo Lula relaciona-se a alguns ajustes ou alterações de programas, e não, necessariamente, de metas políticas, já que, para os autores, estas não foram mudadas de maneira significativa. Nesta direção, enquanto a política externa de FHC defendia a ideia de "autonomia pela participação" no contexto internacional, a qual se contrapunha à busca por “Autonomia pela distância”, prevalecia até o governo de José Sarney, a inserção do Brasil no cenário mundial feita no governo Lula, por um lado, também acentua modos autônomos e, por outro, busca por novos parceiros. Este posicionamento é denominado pelos autores (2007, p.282) “Autonomia pela diversificação”. Nesta busca por parcerias no cenário internacional, a fim de alcançar força política, o governo agiu, "enfatizando a cooperação Sul-Sul para buscar maior equilíbrio com os países do Norte, realizando ajustes, aumentando o protagonismo internacional do país e consolidando mudanças de programa na política externa" (Vigevani e Cepaluni, 2007).

Além do que expusemos, outras especificidades dão entornos aos discursos presidenciais em seu viés internacional. Entre elas, destacamos que o contexto situacional global também se delineia pelo conjunto de interesses, crenças e valores de grupos específicos. Nesta direção, entendemos a existência de ideologias as quais influenciam as práticas discursivas políticas.

Nessa acepção, no caso dos pronunciamentos de Lula, compreendemos que tais práticas discursivas estavam inseridas em uma situação de articulação de forças entre a posição do partido do ex-presidente Lula e as decisões que precisavam ser ajustadas ao momento sociopoliticoeconômico que o Brasil vivenciava em termos de sua política externa. Assim, acreditamos ser possível dizer que era preciso, por um lado, manter uma política 
externa já em desenvolvimento, por outro, inserir crenças e valores do grupo específico (PT) que ascendia ao poder.

Condições como essas fazem que os discursos presidenciais se tornem porta-vozes de ideologias de grupo no cenário global. Mais do que isto, entrelaçam-se e confrontam-se posicionamentos nas relações internacionais, em razão de a configuração que a elas dão corpo ser composta por interesses, valores e crenças múltiplos. Nesta direção, discorremos a seguir a respeito dessa relação existente entre ideologias de grupo e discurso presidencial em seu viés internacional. Utilizando-se desses pressupostos, na sequência, discutimos, em específico, sobre os procedimentos discursivos e ideológicos da política externa do governo Lula.

\subsection{Ideologias de grupo e discurso presidencial em seu viés internacional}

Neste trabalho, a perspectiva teórica que embasa o conceito de ideologia consiste na abordagem sociocognitiva de van Dijk (2004a, 2004b, 2005a, 2005b, 2010), que, como proposta, estuda a relação entre esquemas ideológicos, representações mentais e práticas discursivas. $\mathrm{O}$ autor propõe que as ideologias devem ser entendidas como a base axiológica de sistemas, compartilhados socialmente por comunidades epistêmicas ou por grupos sociais específicos. É neste sentido que elas correspondem a objetos mentais (ideias, pensamentos, crenças, juízos de valor), advindos de uma socialização, a qual faz que haja um desenvolvimento contínuo da cognição política.

Tal pressuposto revela que a estrutura ideológica vai além de um sistema de crenças. Com efeito, ela consiste de normas, valores, metas e princípios, julgados relevantes para algumas pessoas, as quais podem conduzir seus discursos, utilizando-se de todos esses elementos a favor de certas interpretações, percepções e ações, condizentes com seus propósitos sociais e políticos.

Desse modo, as cognições sociais ideológicas correspondem a sistemas coletivos, isto é, configuram-se entre membros e instituições - tal como a política - e englobam construções específicas de realidades sociais, exclusivamente, por conta de determinados interesses (van Dijk, 2010). 
Em relação à ideologia do campo político, van Dijk (2005a, p.25) ${ }^{46}$ entende que:

\begin{abstract}
Embora, principalmente, definidas em termos sociocognitivos, as ideologias políticas permeiam, totalmente, o campo político, tais como os sistemas totais que constituem as democracias (baseadas em ideologias democráticas), seus atos e processos (como governo, construção de coalizões, ou eleições), as práticas políticas diárias (como debates parlamentares ou demonstrações), as relações de grupo (como as de dominação e resistência, governo e oposição), as normas e valores fundamentais (como igualdade e independência, que são categorias constitutivas das ideologias), assim como as atitudes políticas mais específicas (por exemplo, as relativas à legislação sobre o aborto ou divórcio), que são controladas por ideologias.
\end{abstract}

É possível dizer que a ideologia é reproduzida, na maioria das vezes, pelas práticas discursivas. Por meio delas, é que diversas instituições ou outros grupos específicos têm o papel de multiplicar, de formar e de transformar ideologias e, por conseguinte, (re)construir estruturas societais. Para que isto ocorra, no campo da política em específico, tornam-se necessárias crenças comuns, a fim de que os políticos possam, no mínimo, comunicarem-se, mesmo que estejam em jogo poder, luta e interesses diversos nas práticas realizadas entre os grupos.

Nesse sentido, para poderem interagir e competir, os grupos ideologicamente diferentes - tais como os governantes de certos países - necessitam de um espaço comum em termos de conhecimento socioculturalmente compartilhados (van Dijk, 2005a). Como também, eles precisam de uma ideologia consciente e organizada, já que a configuração do campo político, em específico, no internacional, baseia-se tanto nas diferenças de posicionamentos dos governos quanto nas alianças, obtidas por meio de semelhanças ideológicas.

Tendo em vista que a política internacional se organiza a partir de embates e alianças, as formações de grupos precisam e caracterizam-se por haver ideologias, de certo modo, em comum (ONU, BRICs, MERCOSUL etc.), em que, entre os elementos presentes, os

\footnotetext{
${ }^{46}$ Tradução livre: Aunque principalmente definidas en términos de sociocognitivos, las ideologías políticas impregnan por entero el campo político, tales como los sistemas totales que constituyen las democracias (basadas em ideologías democráticas), a sus actos y procesos (como gobierno, construcción de coaliciones, o elecciones), a las prácticas políticas diarias (como debates parlamentarios o demostraciones), a las relaciones de grupo (como de dominación y resistencia, gobierno u oposición), a las normas y valores fundamentales (como igualdad e independencia que son categorías constitutivas de las ideologías), así como a actitudes políticas más específicas (por ejemplo, las relativas a la legislación sobre aborto o divorcio) que son controlados por ideologías.
} 
interesses comerciais ou político-sociais destacam-se nas interações. Até mesmo as propostas de uma política externa envolvem, extremamente, posturas ideológicas (neoliberalismo, conservadorismo etc.) que estarão em jogo no momento das negociações entre Estados.

Para van Dijk (2008), as ideologias contêm graus de complexidade. O autor considera a estratificação e as regras sociais como influenciadores de formação de sistemas ideológicos, que variam conforme o acesso de informação de cada indivíduo. Desta maneira, enquanto alguns grupos e seus membros possuem sistemas mais complexos sobre determinados temas, os de outros podem ser menos precisos, em razão de não terem tido as mesmas experiências e interesses. Isto pode ser relacionado à questão histórica e à cultural de cada país e, consecutivamente, às situações discursivas entre chefes de Estado e de governo, em razão de determinadas experiências de alguns povos não serem as mesmas que de outros, promovendo diferenças na maneira como cada qual entende e se posiciona a respeito de alguns temas.

Montero (2009, p.352) afirma que o discurso presidencial deve ser entendido como prática política e ideológica. A respeito deste último ponto, a autora entende que:

Como prática ideológica, o discurso presidencial apresenta e reflete significados que constroem visões de mundo, da nação, do povo, de sua história, dos eventos e das políticas de cada governo, que naturalizam determinadas explicações, definições e interpretações, apresentando-as como a essência própria da natureza do país, do povo e do governo que se preside. Isto favorece, assim, a hegemonia de certas ideias e de quem as sustentam, em função dos interesses de um grupo e de um líder que emite o discurso, dando curso a expressões ideológicas ${ }^{47}$.

Estendendo essa afirmação ao discurso presidencial em seu viés internacional, temos que cada governo, a partir dos membros que o compõem, busca naturalizar determinadas visões de mundo a respeito de seu país e de sua política exterior. Neste viés, há interesses específicos decorrentes de posturas ideológicas de cada grupo e de seu líder, os quais podem registrar, em seus discursos, recortes sobre determinadas posturas e situações sociais. Isto ocorre devido às experiências individuais dos políticos e também das coletivas que os unem e se tornam bases de apoio, as quais direcionam de maneira específica o exercício de um poder.

\footnotetext{
47 Tradução livre: Como práctica ideológica, el discurso presidencial presenta y refleja significados que construyen visiones del mundo, de la nación, del pueblo, de su historia y de los sucesos y las políticas de cada gobierno que naturalizan determinadas explicaciones, definiciones e interpretaciones, presentándolas como la esencia propia de la naturaleza del país, la gente y el gobierno que se preside. Se favorece así la hegemonía de determinadas ideas y de quienes las sostienen, en función de los intereses de un grupo y un líder que emite el discurso, dando curso a expresiones ideológicas.
} 
Relacionamos tais pressupostos a respeito dos diferentes posicionamentos presentes também nas relações internacionais da política, que dão especificidades aos discursos presidenciais nesses contextos situacionais, dependendo do grupo político em exercício, à afirmação que fizemos em trabalho anterior (PALUMBO, 2008, p. 46):

\begin{abstract}
Sabemos que cada um de nós possui uma história particular e outra coletiva, ambas relacionadas. Isto implica o quanto conhecemos sobre o mundo e sobre nossa língua. Portanto, constituímos crenças, hierarquizamos valores, aprendemos a nos posicionar ideologicamente por meio de nossas vivências. Nesse quadro, as visões de mundo não existem desvinculadas da linguagem, entendida em seu sentido amplo, que comporta a verbal e as não-verbais. Dessa maneira, os sujeitos compreendem e atribuem valores ao mundo também, e principalmente, por meio do discurso, designando-o, problematizando e construindo um posicionamento em relação a ele. Isto quer dizer que a posição que assumimos socialmente já é um recorte de percepção da realidade e nos permite afirmar que não há visão única sobre os fatos observáveis do mundo $[\ldots]$
\end{abstract}

Nessa direção, temos ainda que o tratamento de questões políticas no âmbito externo de um país requer atenção singular e especial, haja vista que se torna necessário ajustar o discurso, para lidar com as diferenças entre as comunidades ideológicas. Isto porque, no jogo político internacional, interesses e entornos socioculturais diversos demarcam a diversidade de posicionamentos ideológicos existente entre os atores desse cenário, isto é, as representações axiomáticas são mediadoras dessas práticas em termos cognitivos e podem ser registradas nos pronunciamentos públicos dos chefes de Estado ou de governo e orientar maneiras de entender o outro e suas propostas. Caberá, aos formuladores do discurso presidencial, adequar tais exigências, a fim de alcançarem os interesses do grupo político dominante.

Salientamos que a configuração do encontro - seleção dos participantes, dos tópicos discursos, dos objetivos interacionais - fornece subsídios para que se localize a ideologia presente nos discursos presidenciais de modo mais ou menos acentuado, servindo a propósitos específicos; isto porque entendemos que seja preciso unir forças. Por tal razão, temos que os registros indicativos de posicionamentos ideológicos servem não para demarcar diferenças acentuadas, que distanciem os participantes em questão, e sim para promover aproximação, principalmente, entre um Estado e os países vistos como parceiros estratégicos. 
Dessa maneira, considerando a existência de outros fatores sociais, culturais, sociocognitivos e pessoais como partes de um sistema maior que orienta a ação dos participantes de uma dada situação, embora as ideologias influenciem e monitorem a prática político-discursiva, não é possível afirmar que elas a determinam, uma vez que não consistem no único sistema mental que controla a produção e a compreensão dos discursos.

Quanto à questão relacionada aos esquemas ideológicos, van Dijk (2005a, 2008) afirma que estes consistem de condutores da autorrepresentação de um grupo. A noção de pertencimento é primordial para que um indivíduo compreenda, primeiramente, a organização de uma sociedade e, consecutivamente, para que reconheça e assuma seus lugares sociais. Por tal razão, categorias são criadas a partir de discriminações e orientam a definição de grupos sociais, dos gerais aos mais específicos: homens e mulheres, velhos e jovens, cidadãos e estrangeiros etc. Neste sentido, por meio de uma séria de classificações, estabelece-se a relação nós vs. eles, na qual se sanciona quem pode ou não pertencer ao grupo.

As atividades dos membros de um grupo e o que se espera deles em termos de comportamentos consistem de outros elementos de construção de uma representação, na medida em que se definem grupos sociais e profissionais por meio daquilo que se presume estar alinhado ou não às funções de seus cargos ou de seus papéis sociais. Neste sentido, as atividades são conduzidas de modos específicos, por estas ações terem de responder a certas normas e valores (critérios ideológicos), assumidos e organizados por uma determinada instituição ou por um número de pessoas, unidas por determinados fatores em comum.

Ainda em consonância com van Dijk (2008), os grupos sobrevivem por meio de recursos materiais ou simbólicos - cidadania, residência, direitos humanos, conhecimento, trabalho, saúde, respeito, discurso político etc. Por conta de precisarem desses meios, para eles garantirem sobrevivência, cada qual age, a fim de conquistar ou de proteger o acesso a determinados recursos, promovendo outros tipos de categorizações de pessoas, tais como: rico e pobre, empregado e desempregado, o que tem casa e o que não tem, entre outros.

Na visão de Charteris-Black (2011), a ideologia é um fenômeno inerentemente social, que contribui para a formação de identidades de grupos e fornece a base para a comunicação de visões de mundo. $\mathrm{O}$ autor ainda assinala que os sistemas ideológicos unem pessoas em interações, nas quais elas trazem propósitos comuns a respeito de algum tipo de ação social. 
Assim, as ideologias, acima de tudo, podem ser entendidas também como précondições para o estabelecimento de legitimidade política, na medida em que certas ações devem ser entendidas como alinhadas, por exemplo, ao conjunto de crenças pertencente a um determinado grupo, a fim de serem reconhecidas como certas e positivas. Neste viés, um discurso presidencial será adequado, caso sejam combinados seleções lexicais, condições situacionais e posicionamentos ideológicos. A este respeito, van Dijk (2010, p. 56) afirma que "Já que os princípios (normas, regras, valores, metas) de legitimidade encontram-se mergulhadas em uma ideologia, os processos de legitimação também vão surgir como processos discursivos".

Nessa direção, o falar de um presidente da República recebe especificidades tanto dos critérios do órgão público e de seu papel institucional, quanto das normas estabelecidas por outros grupos de vários setores da atividade humana. Isto pode ocorrer pelo fato de esse político, ao mesmo tempo, ter filiação com um partido, pertencer a outros grupos sociais (meio em que vive ou viveu), ou mesmo criar alianças no ambiente interno ou no externo de seu país; as condições específicas de produção darão, mais uma vez, o entorno, para que alguns posicionamentos sejam assumidos no discurso e outros, silenciados.

No campo da política internacional, o agir dos membros que compõem o governo de um país é orientado por metas correspondentes às conjunturas de uma sociedade em específico, nas quais existem necessidades singulares e relações diversas, que podem ser entendidas como cooperação ou não entre políticos. Nesta acepção, os governistas assumem valores em função de seus posicionamentos, caracterizados, por vezes, pelas ideologias advindas de seus partidos. Estes sistemas ideológicos distintos podem conduzir os atores políticos a assumirem interesses opostos ou formarem certas hierarquizações de valores - o desenvolvimento econômico, a segurança, a preservação do meio ambiente, a igualdade, entre outros - sustentando um embate de força entre os integrantes do governo federal, a fim de estabeleceram um consenso em termos do que deverão privilegiar em sua política externa.

Nesse viés, embora constem as atribuições de um chefe do poder executivo na constituição $^{48}$, as diretrizes seguidas por cada governo apresentam particularidades, por estarem em jogo critérios ideológicos específicos, principalmente, em relação aos valores organizados e hierarquizados por aqueles que compõem o poder político dominante em exercício. As coligações e parcerias existentes em um governo, portanto, também fornecem

\footnotetext{
${ }^{48}$ Disponível em: < http://www.planalto.gov.br/ccivil_03/constituicao/constitui\%C3\%A7ao67.htm>. Acesso em: 26 ago. 2010.
} 
subsídios para a elaboração das propostas da política externa, conduzindo a certas decisões, também, em termos de práticas discursivas.

Assim é que os políticos se aproximam ou se distanciam dos demais não só pela noção de pertencimento, pelas atividades, pelos objetivos e valores, como também pelo relacionamento estabelecido uns com outros. As definições dos aliados e dos adversários, dos oponentes e dos seguidores, bem como as interações de competição e de conflito, indicam o modo como um político reconhece seu lugar, e o do outro, e se posiciona em dada circunstância.

Para Chilton (2004), em razão de os pontos de vista dependerem de ideologias políticas, ocorre que alguns políticos não necessariamente têm as mesmas interpretações a respeito de uma formulação linguística, ou mesmo, que cada político/grupo tende a utilizar sintaxes e seleções lexicais distintas, para fazer menção a uma mesma situação e criar efeitos de sentido diversos sobre ela. Esse estudioso ainda salienta que muitos locutores negam a possibilidade de determinadas formulações conduzirem a sentidos diferentes, enquanto outros são sensíveis a tais possibilidades de alterações e as assume em sua ideologia política.

Ainda em consonância com Chilton (op.cit.), fazer escolhas linguísticas que coadunem certos valores políticos e sociais é prática recorrente por conta de se reconhecer sua importância na construção de uma imagem pública alinhada às expectativas daqueles para quem os discursos são dirigidos, que também podem agir a partir de um sistema de crenças. Levando-se em conta tal pressuposto, temos que os discursos presidenciais abrangem uma dimensão ideológica registrada por meio de certas escolhas lexicais e seleções de tópicos discursivos, que organizam em categorias certas circunstâncias sociais observadas por um determinado viés, conforme o que foi preferido em termos de interesses no campo político internacional.

Além do mais, a partir do que um grupo de governistas entende sobre a situação discursiva específica, eles poderão posicionar-se ideologicamente e construírem discursivamente o que compreendem por nós e os demais, tal como ocorre nas seleções de formulações, pelas quais alguns agentes são apresentados como responsáveis por situações negativas. Neste processo, delinear-se-ão visões de mundo político-social e revelar-se-ão posturas, por vezes, ideológicas, quando, por exemplo, o procedimento recair sobre generalizações, identificadas por meio de determinadas seleções lexicais e pelas especificidades do encontro. 
Em outras palavras, atribuir certa característica a uma pessoa - cujo grupo e todos seus membros são vistos de uma maneira específica e generalizada - é atitude indicativa de uma postura ideológica, em razão de terem sido criadas, culturalmente, algumas noções, mais ou menos, fixas a respeito de certos indivíduos (políticos, pobres, ricos, estrangeiros, entre outros). Para van Dijk (2008), tais procedimentos vão além de uma categorização avaliativa ou identificadora, consistem também em uma decisão ideológica do locutor e de seus aliados. Assim é que, ao optar por uma expressão ou palavra para se referir a determinados grupos, o político estará opinando ideologicamente, caso estejam subjacentes ideias gerais.

De modo geral, no âmbito da política internacional, quando atento às formulações dos discursos, os políticos selecionam tópicos, informações, argumentos, formulações linguísticas e posicionam-se ideologicamente, levando-se em conta o conhecimento público, as hierarquias de crenças e as possibilidades de consenso. Se, por um lado, podem existir divergências entre os interesses e, consecutivamente, entre as ideologias dos respectivos grupos do poder político, fazendo com que haja necessidade de negociações em alguns momentos, por outro, a prática política implica cooperação, constituição de alianças, sanção positiva por parte de uma sociedade como um todo.

Dessa maneira, pelo que expusemos, existem posicionamentos ideológicos que demarcam os interesses de um grupo. Não se trata de considerar a realidade social, mas sim "uma construção ideológica autosservida, uma autoimagem do grupo e suas relações com os demais grupos" (VAN DIJK, 2008, p. 212 $2^{49}$ ). Nesta acepção, as ideologias organizam os esquemas mentais sobre determinados temas, que se multiplicam e são compartilhados pelos membros de um grupo.

Entendemos que tais construções ideológicas estiveram presentes nos procedimentos adotados pelo governo Lula em sua política externa; em específico, consideramos ter havido posições, que podem ser associadas aos valores e as crenças do Partido dos Trabalhadores. Assim, tem-se que o discurso presidencial desse político, em seu viés internacional, insere-se em um contexto (cognitivo e situacional) também marcado por um posicionamento partidário.

\footnotetext{
49 Tradução livre: una construcción ideológica autoservida, una autoimagen del grupo y sus relaciones con los demás grupos.
} 


\subsubsection{Posicionamento ideológico no discurso de Lula}

A partir da discussão apresentada no subitem anterior, torna-se possível afirmar que o dizer de um político - como o de um presidente da República - pode ser entendido como um portador de valores e de crenças. Além disto, o locutor assume para si seu discurso, isto é, as informações selecionadas, os posicionamentos apresentados são relacionados à figura de quem enuncia, de modo a fazer que haja associações positivas ou não entre a pessoa que fala e sobre aquilo que ela diz e como o constrói.

Nesse viés, temos o pressuposto de que a busca por parcerias estratégicas etc. no cenário internacional, a qual implica a promoção de um conjunto de fatores pertinentes a um Estado, envolve a imagem de seu governo e de seu governante. Isto porque, como já mencionamos, as imagens a respeito de um político, construída por parte de seus interlocutores, podem gerar expectativas em termos de posicionamentos políticos e sociais. Seguindo nesta direção, a imagem de um presidente da República pode ser relacionada a um determinado grupo, caso esse político evidencie seu papel, na prática discursiva, como representante ou como aliado de certas pessoas.

Assim, partimos do pressuposto da existência de associações acerca da imagem de um país e de seu governante, em razão de este representar seu Estado. Um presidente da República atua, em situações face a face, de maneira a tornar presente o que, de fato, está distante do dia a dia dos políticos do exterior. Este locutor, também por fazer parte do grupo que detém poder de tomar certas decisões de ordem interna, ao promover seu pais, autopromove-se, e vice-versa.

Nessa direção, parece-nos significativo indicar a afirmação de Almeida (2012) sobre o investimento da política externa do governo Lula ser ajustado à figura do ex-presidente. Para o autor, muito do sucesso da promoção do Estado brasileiro na era Lula foi devido à própria imagem socialmente construída do ex-presidente do Brasil. Nas palavras do estudioso (op. cit., p. 110):

É verdade que a história pessoal de Lula, pelo menos daquela construída expressamente para sustentar uma versão nem sempre muito fiel de sua carreira política - que é sempre mais interessante politicamente do que os muitos anos de "trabalhador pobre" e de "sindicalista alternativo" -, servia perfeitamente para compor um itinerário de sucesso individual, o que foi suficientemente exaltado pela imprensa brasileira e pela mídia estrangeira, as verdadeiras responsáveis pela transformação de um líder de um partido esquerdista, tipicamente latino--americano - inclusive em 
seu antiamericanismo primário - em verdadeiro líder providencial e condutor de um grande país do Terceiro Mundo, numa versão aceitável para a ordem normal do capitalismo global.

Almeida (2012) afirma que a imprensa internacional também colaborou para a construção “do mito do 'bom selvagem"”. O Partido dos Trabalhadores (PT) e o próprio então presidente da República fabricaram materiais publicitários, pelos quais se sustentava a ideia de fazer de Lula um dos grandes decisores mundiais. Tais procedimentos centrados na figura de Lula direcionaram a uma diplomacia personalista e, para Almeida (op. cit.), isto acarretou em um dos sucessos no plano internacional.

Esse objetivo foi mobilizado pelo Itamaraty. No âmbito global, fato é que houve, em primeiro plano, a promoção da imagem do presidente, embora tenham existido algumas razões para o sucesso do Brasil - como as assinaladas por Almeida (2012, p.110):

[...] a manutenção da estabilidade econômica, inclusive dos acordos com o FMI, a responsabilidade fiscal, a preservação do sistema de flutuação cambial herdado do governo precedente, o grande crescimento puxado pela expansão da economia mundial, a oferta abundante de capitais de empréstimo e de investimento, a voracidade importadora chinesa.

Ainda a respeito dessa autopromoção de imagem, diz Almeida (2012) que, não só no plano interno, mas também na diplomacia de Lula e seu governo, ocorreu um retorno a um passado mítico, o do "desenvolvimentismo" da década de 50 do século XX e também do planejamento estatal conforme regime militar (1964-1985), sobretudo, em relação à construção imagem de um Estado forte, característica do governo de Ernesto Geisel (19741979). Houve referência à política externa independente do início dos anos 60, quando descrita na diplomacia Lula como ativa e altiva.

Assim, um político que conduziu para si uma imagem pelo viés dos direitos humanos, detrás do qual existem razões que o legitimem - como as tradições sociais e as regulamentações de um Órgão Internacional de importância significativa como a ONU pode agir em prol de convalidar seu mandato, assegurando-se por meio desse modelo mental e relacioná-lo às (re)construções cognitivas de um Estado sob sua direção.

Pode-se afirmar, ainda, que foi nos pronunciamentos do ex-presidente que se privilegiou a questão da necessidade de novos caminhos em termos de política internacional. 
Alguns estudiosos, como Almeida (2004, p.2), entendem que, no plano prático da política, muitas dessas iniciativas, como a preferência pelo MERCOSUL, foram oriundas de um desdobramento em curso no governo anterior, conforme se observa a seguir:

Muitas dessas novas iniciativas constituem, na verdade, desdobramentos e reforço de ações já em curso na administração anterior, embora com nova roupagem e novas ênfases conceituais, o que as colocaria mais na linha da "continuidade" do que na de "ruptura" 50.

Entende-se que estava imbricada, nas práticas discursivas desse governo, a postura ideológica da necessidade do novo, mesmo que atitude e proposta não tivessem sido, assim como Lula evidenciou em seu discurso de posse (segmentos 3 e 4, anexo 01), propriamente rupturas de sucessivos processos de uma administração precedente, mas sim, de algum modo, uma continuidade. Almeida (2004) ainda afirma que os discursos do PT já enfatizavam alianças preferenciais com países do sul durante muitos anos, reforçando a ideia de haver um posicionamento partidário na ação governamental.

Nesse sentido, como já destacou Charaudeau (2006), o discurso não esgota o conceito político, mas o primeiro possibilita dar sentido a determinadas ações políticas, estando estreitamente ligado à organização da vida e ao engajamento dos indivíduos. Assim, a proposta política precisa ser sustentada pelo discurso, que a contorna, é constitutivo e constituinte dela.

O fato é que qualquer que seja a proposta política de um grupo dominante, manifestações discursivas precisam ser mobilizadas, para que haja espaços de discussão e se chegue aos acordos esperados. Assim, mesmo que entendamos o discurso como atividade que não esgota em si a prática política, não se pode negar que esta se desenvolve por meios discursivos, como também já assinalou Charaudeau (op. cit.).

Com efeito, embora tenha havido um posicionamento, no e pelo discurso, ligado à alteração de planos em relação ao governo precedente, entende-se que estes relacionamentos estratégicos começaram a se delinear no final da administração de FHC, assim como também assinalam Vigevani e Cepaluni (2009, p. 81): "Lula deu uma nova ênfase para este aspecto da nova agenda internacional do Brasil"

\footnotetext{
${ }^{50}$ Grifo do autor.

${ }^{51}$ Tradução livre: Lula gave a new emphasis to this aspect of Brazil's international agenda.
} 
Lula ainda interveio em algumas campanhas presidenciais de alguns países vizinhos e também europeus em favor de candidatos, cujas posições ideológicas estavam alinhadas ao Partido dos Trabalhadores (PT). Isto pode ser considerado como uma marca de posicionamentos ideológicos presentes no governo de Lula. Outras tantas atitudes de cunho partidário podem ser observadas durante os dois mandatos. Entre elas, destaca-se o caso da guerrilha colombiana e seus desdobramentos militares e políticos. Por um lado, tal apoio revela uma diplomacia esquerdista que, conforme Almeida (2012), comprometia as relações entre Estados. Para o autor, houve tolerância por parte de Lula para com seus aliados ideológicos, principalmente, com os vizinhos regionais.

É nesta direção que seguiu a política externa brasileira durante o governo de Lula. Marcada por posicionamentos ideológicos, houve na época de transição governamental, um processo de um "reenquadramento ideológico" (ALMEIDA, 2012, p. 109) reconhecido no plano interno. Como também, as propostas da diplomacia desse governo foram baseadas na ideia de afastamento do governo norte-americano sobre as questões políticas latinoamericanas. Isto fortalece a simpatia entre o Brasil e alguns líderes latino-americanos de maneira independente de processos políticos e econômicos, uma vez que a comunhão se estabelece em termos de valores e de posicionamentos ideológicos (ALMEIDA, 2012).

Nesse viés, Vigevani e Cepaluni (2007, p. 276-277), citando Soares de Lima, entendem que:

Acreditamos que uma das principais diferenças entre a administração Lula da Silva e a de FHC reside nas diferentes interpretações e ideologias destes líderes (e dos funcionários que os acompanham) a respeito dos constrangimentos e das possibilidades da ordem internacional vigente (SOARES DE LIMA, 2005, p. 35).

Esses autores partem do pressuposto de Hermann (1990), para quem as mudanças da política externa correspondem a um processo contínuo, no qual estão implicados pequenos ajustes, modificações de objetivos e de programas, alterações de comportamentos dos países em âmbito internacional. Para este estudioso, estas mudanças podem ser examinadas a partir dos líderes políticos, dos burocratas, da reestruturação doméstica e dos choques externos.

Dessa maneira, essas alterações são efetivadas, ainda conforme Hermann (op. cit.), pela participação de certos atores políticos - sobretudo, da liderança política; no caso do Brasil, pode-se observar o presidente da República como líder e promissor de mudanças - e 
dos eventos nos quais eles estão engajados. Além do mais, boa parte das ações que visam à mudança delineia-se a partir da percepção dos líderes ou dos agentes formuladores da política a respeito do cenário global. Para Vigevani e Cepaluni (2007), estas percepções são variadas e, nelas, estão imbricados alguns fatores como: mudanças econômicas, relações de poder internacional etc.

Como também, para Vigevani e Cepaluni (2007), são as diferenças ideológicas e, assim, de concepções de mundo, bem como as diferenças de personalidades e de modos de entender os eventos internacionais por parte de Lula e de FHC os fatores que promovem mudança de comportamento. Nesse sentido, a tomada de decisão pode ser atribuída ao líder, ao seu grupo e a outros envolvidos direta ou indiretamente nas questões de ordem internacional.

É possível afirmar que a diplomacia do governo Lula reflete os posicionamentos políticos de seu partido, o PT. Algumas escolhas feitas por essa diplomacia são explicadas a partir dos interesses do partido e de sua ideologia. Principalmente, há de se reconhecer a postura avaliativa que versou sobre a ideia de construir categorias organizadoras do mundo político global, em que há o terceiro mundo e o imperialismo dos países desenvolvidos (antiimperialismo). Nesta direção, diz Almeida (2004, p. 1):

\begin{abstract}
A política externa do governo Luiz Inácio Lula da Silva é, provavelmente, a vertente da atividade governamental que mais reflete as antigas propostas e as posições tradicionais do Partido dos Trabalhadores. Com efeito, nem na política econômica, nem em ações setoriais tomadas até o momento pelos vários ministérios é tão nítida a "filiação genética" com posições ostentadas historicamente pelo PT - tal como refletidas em teses programáticas e em declarações e textos de seus líderes ao longo dos últimos vinte anos - como nas iniciativas tomadas desde início de 2003 no âmbito da diplomacia. Em outros termos, é nas relações exteriores e na sua política internacional que o governo do presidente Lula mais se parece com o discurso do PT.
\end{abstract}

Entendemos que, no governo Lula, em sua política externa, os tópicos discursivos voltados para a justiça social já podem ser considerados indícios de um posicionamento ideológico-partidário, tal como discutimos. Assim também, o fato de se atribuir a ideia de mudança, em vez de continuidade do governo anterior, pode ser indicativo de uma busca por ajustamento de imagem (nós vs. eles) correspondente ao grupo do Partido dos Trabalhadores (PT). 
De modo geral, pelo exposto neste capítulo, pode-se dizer que os pronunciamentos do ex-presidente Lula trazem especificidades próprias do discurso político, principalmente, em seu viés internacional e, ao mesmo tempo, apresentam posicionamentos do PT. Além do mais, em razão de se ter apresentado promessas, ligadas a mudanças de ordem nacional e internacional, e de se posicionar como promissor de mudanças, temos que essas práticas discursivas de Lula e de seus assessores revestem-se de estratégias argumentativas, a fim de se validarem essas propostas e, assim, de se alcançarem certos credenciamentos no cenário global. Entre as possibilidades de se agir de modo argumentativo, discutiremos, no próximo capítulo, sobre os caminhos da argumentação nos discursos políticos, nos quais a metáfora está presente de maneira significativa. 


\section{CAPÍTULO IIII}

\section{CAMINHOS DA ARGUMENTAÇÃO: A CONSTRUÇÃO DE MUNDOS METAFÓRICOS NOS DISCURSOS POLÍTICOS}


In political rhetoric, the primary purpose of metaphors is to frame how we view or understand political issues by eliminating alternative points of view. Politicians use metaphors for negative representations of states of affairs that are construed as problematic and positive representations of future scenarios that are construed as solutions of problems; they also use them for negative or positive representations of out-groups (i.e. opponents) and of in-groups (i.e. supporters) respectively. So they combine the rhetoric of right thinking with sounding right and having the right intentions.

Charteris-Black, 2011

Tendo em vista que a metáfora faz parte de nosso cotidiano - na apreensão, na interpretação e, consecutivamente, na negociação de sentidos de objetos de discurso diversos, dada na prática discursiva - é possível dizer que ela está imbricada em nossas construções sociocognitivo-discursivas do mundo e de nós mesmos, que circulam na sociedade em vários campos de atuação humana, desde discursos do cotidiano até os mais complexos e planejados, como os do campo político.

Pode-se afirmar que o discurso político dialoga com os do cotidiano, apropriando-se de falares específicos do dia a dia deste seu significativo auditório: a população. Esta, por sua vez, também recebe influência por meio das diversas interações nas quais se torna possível aproximar, de certo modo, o cidadão à cena política, ou mesmo, esta de seus vários autores políticos em uma dimensão nacional e global. Nesta direção, estas instâncias sociocognitivas legitimadas são interpeladas pelos discursos políticos situados em condições específicas de produção, ajustando-se a estas de maneiras diversas, e vice-versa.

Assim, entendemos que metáfora e discurso interligam-se a fatores contextuais; como já mencionamos no capítulo I, a primeira estrutura o segundo, e este estrutura a primeira de modo a disseminá-la, reproduzindo-a de diversos modos na sociedade. É, pois, conforme afirma Vereza (2010, p.60), "na intersecção entre o social e o cognitivo que a metáfora se torna discurso". Neste viés, acreditamos que a metáfora posta no discurso político recebe deste toda sua complexidade e importância para a prática política. 


\subsection{Função da metáfora nas finalidades argumentativas: compreensão do discurso e aproximação com o auditório}

Como já expusemos, à página 51, Marcuschi (2007) ressalta que o dizer é interpretável, na medida em que se oferece ao outro condições para que ele tenha acesso a informações postas ou inferíveis no processamento discursivo e nos dados contextuais específicos (situacionais e cognitivos). Isto significa também que cabe ao locutor selecionar informações, reforçando alguns recortes e omitindo outros, e organizá-las de maneira a mostrar ao interlocutor um caminho para ele chegar a uma determinada conclusão. Entre estes procedimentos, destaca-se a seleção de formulações metafóricas, por se considerar, também, que elas propiciam uma expressividade maior do que as não metafóricas, uma vez que despertam sensações e enfatizam certos recortes, conforme postulam Perelman e OlbrechtsTyteca (2002 [1958]).

No e pelo discurso político, é importantíssimo alcançar uma das finalidades básicas da Retórica Clássica: instruir (docere), ou mesmo, orientar os interlocutores para a interpretação mais adequada, conforme a proposta enunciativa do locutor. Consecutivamente, a ação sobre o outro implicará agradá-lo de algum modo (delectare), aproximá-lo e tocar sua razão e sua emoção de tal maneira que se consiga provocar determinadas reações (movere).

Pelo fato de as pessoas, frequentemente, terem conhecimentos parciais sobre determinadas questões políticas, visto que estas tendem a ser complicadas e abstratas (Charteris-Black, 2011), pode-se dizer que a seleção de metáforas conceptuais colabora para o alcance dessas finalidades argumentativas (docere, delectare, movere). Isto porque o dizer metafórico permite estender conhecimentos familiares a campos mais complexos, oriundos de experiências situadas e imediatas do fazer político, podendo fortalecer a argumentação apresentada, já que ajuda na instrução (docere) do discurso - por simplificar algumas questões de ordem política, tornando-as inteligíveis - e também favorece mapeamentos particulares no universo discursivo, os quais poderão ser alinhados à tese defendida pelo locutor, de modo a estruturar tanto o discurso quanto a argumentação.

Assim, para as finalidades argumentativas, que implicam o uso estratégico da linguagem, pode-se afirmar que selecionar determinadas expressões linguísticas metafóricas é questão de escolha situada social e historicamente, como também, não se pode negar que o fato de escolher uma metáfora conceptual em vez de outra pode implicar uma estratégia de uso do pensamento para fins argumentativos do político e/ou de seu grupo. No discurso 
presidencial, por diversas vezes, elas também são usadas para os objetivos da diplomacia e da política externa. Neste viés, buscar com que os políticos do exterior entendam o que se propõe e construam determinada imagem sobre aquilo que está distante em termos de espaço e de cultura (um Estado a partir de um viés) pode ser uma ação possível por meio da metáfora.

Dessa maneira, as metáforas colaboram para dar ênfase a uma dada construção discursiva do real, conforme os propósitos enunciativos de quem a produz, na tentativa de fazer que o outro compreenda e veja certa situação de determinada maneira. Em outras palavras, elas possibilitam que o locutor leve à presença dos interlocutores uma imagem específica daquilo sobre o qual se fala em uma perspectiva norteadora de conclusões. Tal afirmação embasa-se nos pressupostos de Perelman e Olbrecths-Tyteca (2002 [1958]), autores que também discorrem a respeito do papel da metáfora na argumentação. Para eles, a força argumentativa da metáfora consiste de fazer que o outro veja um objeto conforme a maneira que lhe é apresentado, provocando, assim, um efeito de presença. Além deste, as metáforas nessa teoria, consideradas figuras de retórica - provocam outros efeitos argumentativos, que podem ser coexistentes: o de comunhão entre orador e auditório, chegando aos lugares comuns; o de aconselhamento ou de sugestão de escolhas.

Levando-se em consideração os pressupostos desses autores, pode-se entender que o papel argumentativo da metáfora nessas práticas discursivas estabelece-se a partir dos efeitos que ela pode provocar, ou mesmo, reforçar, fazendo com que haja a possibilidade de diminuir distâncias em termos cognitivos. Nessa direção, também diz Vereza (2010) que a metáfora posta em discurso convence a partir das imagens que ela cria, das emoções que trás e da força cognitiva pela qual é possível estabelecer conexões entre domínios que pareciam desconectados. A autora segue afirmando que tal relação/conexão permite ao interlocutor uma participação na construção do sentido, fazendo com que ele se torne cúmplice do argumento. É neste viés que a metáfora permite aproximação, isto é, comunhão entre orador e auditório.

Nesse sentido, a seleção da metáfora cumpre papel argumentativo significativo para que orador e auditório se unam em prol de interesses entendidos como comuns. Para a compreensão do discurso, por si só, a seleção metafórica favorece um olhar, o qual talvez não fosse o mesmo sem ela. Como dizem Perelman e Olbrecths-Tyteca (2002 [1958], p.455): "Esses termos não devem ser considerados subentendidos, pois cumpre admitir que a fusão, uma vez realizada, criou uma expressão que basta a si mesma". 
A metáfora, geralmente, é dialógica, pois é selecionada para diversos interesses, por exemplo, políticos, e propósitos interativos específicos. Portanto, quanto mais uma associação for apresentada ao auditório, mais este estará apto a retomá-la e reforçá-la, ajustando-a ou não, utilizando-a para manter posicionamentos e raciocínios ou mesmo refutálos. Ilustramos tal afirmação com a formulação "Cortaremos na própria carne" (linha 187, anexo 12), selecionada pelo ex-presidente da República Luís Inácio Lula da Silva. Entendemos que este segmento, em que Lula ativa o objeto carne/corpo, a fim de mencionar sobre sua relação com o PT e a respeito de uma possível punição de alguns petistas, seja de entendimento fácil em razão de ativar conhecimentos relacionados ao corpo humano.

De fato, posteriormente ao pronunciamento, vários discursos de políticos e de jornalistas retomaram tal formulação, construindo sentidos diversos ${ }^{52}$. Muitos deles, feitos por petistas, fizeram dela argumento para fortalecer a imagem de ética e de união do partido, outros, em contrapartida, selecionaram-na para por em evidência o não cumprimento da promessa feita pelo ex-presidente da República, como na manchete de uma notícia do jornal O Globo, de 9 de junho de 2005, divulgada também no site do PSDB (Partido da Social Democracia Brasileira): "PT se recusa a "cortar na própria carne", ${ }^{, 53}$. Bem como, essa metáfora foi utilizada para ironizar as palavras de Lula, como no título da charge de Erre publicada em 20 de junho de 2005, em que o chargista faz menção ao distanciamento de José Dirceu do cargo de ministro da Casa Civil: “Cortar na própria carne. E começou pelo braço direito" ${ }^{54}$. Em âmbito internacional, também houve retomadas diversas como: "Lula is under the gun-again", 55 , em 19 de junho de 2005, "In its report, the investigating committee says Brazil's parliament must now cut off its own flesh to win back public trust ${ }^{, 56}$, BBC News, em 2 de setembro de 2005.

Assim é que a metáfora, de certo modo, interfere - esclarecendo e aproximando - na construção discursiva de situações sociais e, concomitantemente, nas imagens mentais de agentes, de processos etc. No encontro das informações armazenadas do eu e do outro, tanto as pré-concebidas quanto as adquiridas no momento interacional, está a metáfora, trazendo velhos modelos mentais, revivendo-os e recriando-os inúmeras vezes, para compor o que de

\footnotetext{
${ }^{52}$ Discutimos com mais detalhes a questão da construção de sentidos metafóricos diversos no subitem 3.5 deste ${ }_{53}^{\text {capítulo. }}$

Disponível em: http://www.psdb.org.br/pt-se-recusa-a-\%C2\%A2\%C2\%A2cortar-na-propriacarne \%C2\%A2\%C2\%A2/. Acesso em 17 nov. 2012.

${ }^{54}$ Disponível em: http://www.portogente.com.br/texto.php?cod=2863\&sec=60. Acesso em 17 nov. 2012.

${ }^{55}$ Disponível em: http://www.businessweek.com/stories/2005-06-19/lula-is-under-the-gun-again. Acesso em 17 nov. 2012.

${ }^{56}$ Disponivel em: http://news.bbc.co.uk/2/hi/americas/4207100.stm. Acesso em 17 nov. 2012.
} 
fato não está fixamente pronto em termos de sentido. É, então, na plasticidade de seu uso em interações sociais diversas que ela atua com toda sua conjuntura de implicações e reveste-se do dinamismo inerente às práticas humanas, discursivas e argumentativas.

\subsection{Potencial da metáfora no dinamismo da argumentação}

De acordo com Charteris-Black (2011, 2009), o papel da metáfora consiste de, simultaneamente, apresentar argumentos políticos, posicionar-se ideologicamente, alcançar ou intensificar a emoção do interlocutor e criar imagem de integridade a quem fala. Esse estudioso segue afirmando que a ação argumentativa implica um efeito de "ser certo", ou seja, a argumentação é efetivada caso o auditório esteja convencido de que o orador político tem a intenção certa em relação a seu grupo. Para que tal efeito seja alcançado, o orador precisa obter credibilidade e, para tanto, a construção de uma imagem de integridade ética e moral é fundamental, como afirma o autor (op.cit., p.14): “Quando as pessoas já não confiam em seu líder, quaisquer argumentos ou narrativas que ele oferece não serão persuasivos" ${ }^{\text {"57. }}$.

Observa-se tal relação entre o político e o povo. Muitos escândalos de corrupção no campo político podem levar à desconstrução de uma imagem de pessoa correta, em termos de valores ligados ao conceito de moralidade e ao de ética. Nestes casos, entende-se que o político não agiu em prol dos cidadãos, mas sim de seus próprios interesses. Parece-nos significativo lembrar, a respeito deste tópico, o que discutimos à página 102, a respeito da crise política do governo Lula, iniciada por denúncias de corrupção, as quais envolviam alguns políticos do Partido dos Trabalhadores (PT) e o ex-presidente da República Luis Inácio Lula da Silva indiretamente.

Tal relação ocorreu tanto por ele ter sido reconhecido como o líder do PT, quanto por ter encaminhado uma imagem de si associada a um defensor da classe trabalhadora e dos mais pobres. As denúncias, ocorridas em seu primeiro mandato, a partir de 2005, teve repercussão nacional e internacional e, provavelmente, consistiram em um fator influenciador de opiniões, uma vez que é possível que um auditório fique predisposto a construir uma imagem negativa do grupo e, consecutivamente, de seus membros, ou vice-versa.

Em relação à imagem de Lula no exterior, distancia-se dos objetivos deste trabalho uma discussão minuciosa a respeito do ethos (em sentido tradicional) construído nos

\footnotetext{
57 Tradução livre: "When the people no longer trust in your leader, any arguments or narratives that he offers will not be persuasive".
} 
pronunciamentos do ex-presidente da República em encontros entre líderes políticos mundiais. Contudo, não se pode negar que os tópicos selecionados, os posicionamentos assumidos e, até mesmo, as metáforas escolhidas são procedimentos, que moldam o ethos e, ao mesmo tempo, são moldados pela figura de quem o enuncia. Além disto, a situação de interação será sempre singular, assim também será o discurso, nela, inserido.

Nesse viés, não podemos negar o fato de que tanto os efeitos de sentido desses discursos proferidos e das metáforas conceptuais selecionadas quanto à aceitação das teses apresentadas por Lula, como chefe de Estado, dependem muito da imagem social e historicamente construída pelo auditório a respeito desse orador. Isto porque, embora o discurso político costume ser multiautorial (Charteris-Black, 2011, van Dijk, 2010), assim como já o discutimos, o orador não deve ser considerado um mero porta-voz, quer porque ele, geralmente, tem a oportunidade de editar o conteúdo do discurso ou mesmo de improvisar, quer pelo fato de esse político ter estatuto oficial e seus pronunciamentos serem considerados de domínio público, afastando desse orador a possibilidade de negação ou de renegação do que foi dito. Por conta disto, as palavras pronunciadas por um político podem voltar para ele, caso alguém queira consultar sua integridade moral e a consistência de seu discurso.

Dessa forma, embora levemos em consideração que os discursos políticos institucionais sejam, frequentemente, coletivos, isto é, a pessoa quem o pronuncia não é a única que o escreveu, ou mesmo, não corresponde ao autor do texto, podemos afirmar que o fato de ser Lula quem diz, relacionado ao lugar da interação e ao papel assumido por ele, já confere à organização do discurso e à argumentação uma configuração particular e, também, desperta atenção e interesses específicos por parte dos interlocutores.

Ainda a respeito dessa relação orador e discurso, Perelman e Olbrecths-Tyteca (2002 [1958], p. 361) assinalam que a pessoa que diz é o fator extralinguístico mais significativo na construção de sentidos e do alcance de uma afirmação. Os autores também ressaltam que "mesmo as palavras alheias, reproduzidas pelo orador, mudam de significação, pois quem as repete sempre toma para com elas uma posição, de certa maneira nova, ainda que seja pelo grau de importância que lhes concebe".

O fato é que a sociedade possui normas, que autorizam o orador a se pronunciar, a tomar a palavra e a discorrer sobre determinados tópicos. Quando autorizado, provavelmente, aproveitará do momento enunciativo para apresentar um discurso que toque de alguma maneira o outro de modo a manter ou alterar a imagem de si e dos objetos de discurso 
ativados com a finalidade de conduzir olhares e alcançar adesão. No caso dos pronunciamentos do ex-presidente da República, não ocorre de modo diferente, os efeitos de sentido são influenciados pela figura pública desse orador, pela organização de seu discurso, por outros fatores multimodais que conferem força argumentativa ao seu pronunciamento e pelo diálogo estabelecido entre todos esses elementos e o auditório. Assim é que uma imagem de integridade se torna essencial para os propósitos de um grupo político.

Para Charteris-Black (2011), integridade é fator de disputa entre políticos para alcançarem legitimidade e pode ser entendida, em um conceito geral, como inter-relação entre discurso (o que é dito) e comportamento (conduta). Nesta direção, o autor afirma que o potencial argumentativo da metáfora pode ser entendido a partir do conceito tradicional de logos (argumentos baseados no racional), de pathos (apelo às emoções) e de ethos (imagem ética do falante, credibilidade). A articulação desses três fatores relaciona-se ao objetivo básico da argumentação política que é o de estabelecer legitimidade a um conjunto específico de ações sociais.

Nessa direção, Charteris-Black (2011) estende o modelo retórico clássico e elabora um esquema de argumentação política, de modo a incluir a cognição:

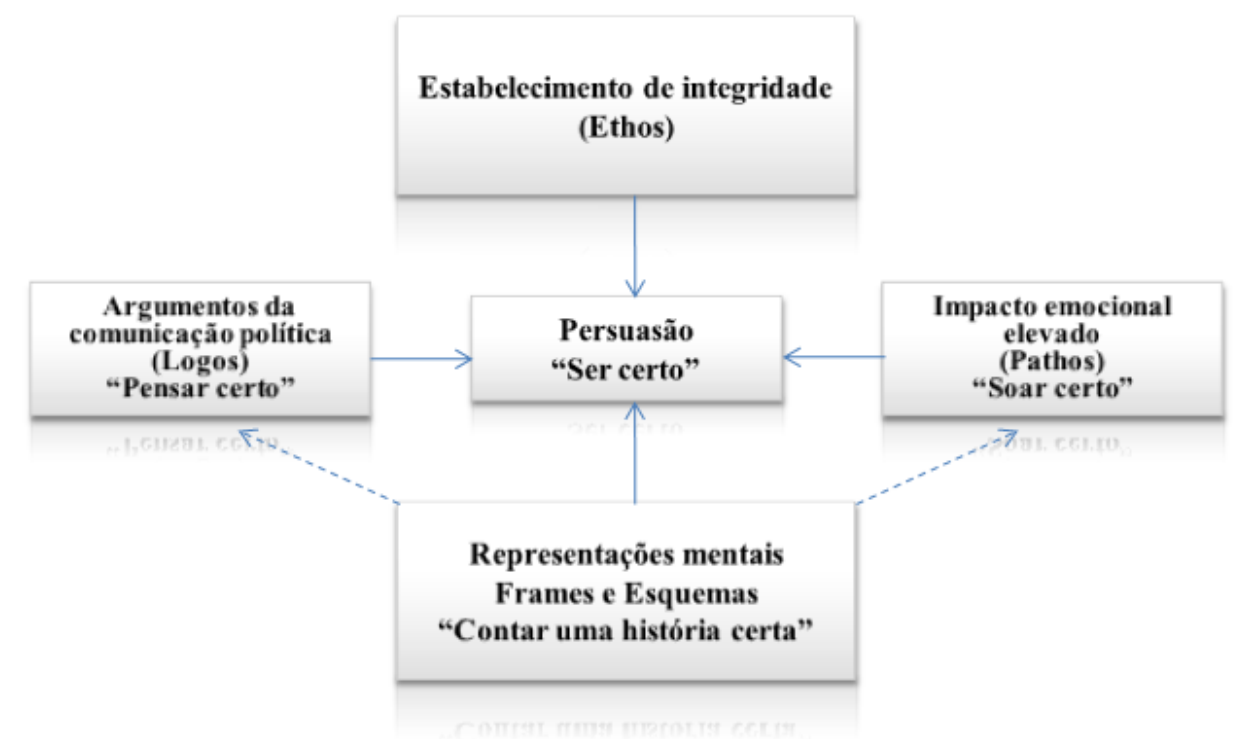

Figura 2. Esquema da argumentação política de Chateris-Black (2011, p.14)

Quanto ao efeito de "Pensar certo" (à esquerda da figura 02), afirma Charteris-Black (2011) que uma maneira de persuadir o auditório consiste de apresentar argumentos pelos quais as ações políticas possam ser vistas como racionais, coerentes. As metáforas colaboram 
neste processo, uma vez que, como já o dissemos, ativam conhecimentos familiares a partir dos quais os políticos podem orientar o auditório a vê-los como aqueles que pensam de modo racional sobre determinadas questões de ordem política. Selecionar uma metáfora permite que o orador utilize um conhecimento que o auditório já possui para fazê-lo entender, de certo modo, novas situações, mais complexas ou não, a partir de inferências.

Sobre isso, temos que a construção de objetos de discurso com sentido metafórico pode ajudar o orador a reforçar ou a alterar uma imagem de si ou de outros já pré-estabelecida socialmente pelo viés do pensar certo. No caso de Lula, sabemos que foi criada a imagem de um esquerdista que agia em prol dos direitos dos trabalhadores. Como chefe de Estado, por um lado, tal modelo mental pode favorecer este orador perante alguns auditórios, como uma parcela da população brasileira ou de outra que tenha criado identificação com a história dele. Por outro, auditórios específicos podem observar Lula e seu governo como um grupo, cujos interesses não coadunam com os propósitos daqueles. Em termos globais, por exemplo, a construção do novo (Lula como chefe de Estado, governo Lula, Brasil no governo Lula etc.) é de extrema importância para conseguir credibilidade. É por conta disto que, ao mudar de papel social - neste caso, de político da oposição para governante - é comum que as atitudes e os procedimentos discursivos do político também se alterem, tal como já afirmado por Perelman e Olbrecths-Tyteca (2002 [1958], p. 24): “Ocorre o mesmo com a mentalidade de um político cuja visão muda quando, após anos passado na oposição, forma-se membro responsável do governo". Isto porque o efeito de "pensar certo" está diretamente relacionado ao papel que foi confiado ao político e ao que se espera dele.

Como também, cenários metafóricos ${ }^{58}$ são selecionados para enquadrar uma situação de uma maneira que este recorte seja favorável aos propósitos do orador político, que é o de se mostrar crível. Isto ocorre a partir de um processo em que são colocados, em primeiro plano, alguns recortes da questão política, enquanto outros são postos em segundo, isto é, não aparecem. Portanto, a seleção de um conjunto de referências do domínio-fonte serve para delinear o que será visto ou apagado.

Ressaltamos que a seleção do que será apresentado ao auditório em termos de informações e de recortes é um fator importantíssimo em razão do efeito de presença que pode provocar, já mencionado à página 128 deste trabalho, a partir do qual se torna possível

\footnotetext{
58 Termo utilizado por Mulsoff (2006) para indicar o papel explicativo da metáfora. Charteris-Black (2011 [2005]) emprega-o para indicar também a função argumentativa da metáfora, principalmente, por ela colaborar na criação dos efeitos "pensar certo" e "contar uma história certa".
} 
agir diretamente sobre a sensibilidade, a percepção do outro, tal como foi postulado por Perelman e Olbrechts-Tyteca (2002 [1958]):

\footnotetext{
O fato de selecionar certos elementos e de apresentá-los ao auditório já implica a importância e a pertinência deles no debate. Isso porque semelhante escolha confere a esses elementos uma presença, que é um fator essencial da argumentação, por demais menosprezados, nas concepções racionalistas do raciocínio.

[...] o que está presente na consciência adquire uma importância que a teoria e a prática da argumentação devem levar em conta. Com efeito, não basta que uma coisa exista para que se tenha o sentimento de sua presença.
}

Sabemos que a questão não é apenas falar a respeito de um objeto e trazê-lo à lembrança, mais do que isto, consiste no modo de dizê-lo, de construí-lo. Se a ativação de um domínio-fonte - estruturado por categorias específicas - traz à presença determinados elementos familiares, a função destes é a de possibilitar inferências, a partir das quais serão ativados e categorizados outros objetos de discurso de modo a estruturar o raciocínio dos participantes, num processo cuja conclusão é orientada a partir da apresentação de referências múltiplas. Tais afirmações ajudam a entender a importância da metáfora na argumentação.

A associação de domínios múltiplos, ativada no desenvolvimento do discurso, pode levar o auditório a ter diversas reações. Isto porque as informações postas dialogam com o auditório e com todos os elementos que o compõem, enquanto indivíduos cognoscentes e atrelados às características de seus corpos. Tal acepção implica que razão e emoção caminham lado a lado e consistem em fatores sobre os quais os discursos agem e, formam e transformam. É esta relação estreita entre o "Pensar certo" ao "Soar certo" que CharterisBlack (2011) afirma ocorrer no dinamismo da argumentação, em que a metáfora atua.

\subsubsection{Emoção e razão lado a lado}

Em relação ao impacto emocional, sabe-se que muito já foi discutido a respeito da necessidade de tocar os juízes (auditório), de modo que eles possam ser orientados a dadas ações (Aristóteles, Perelman e Olbrechts-Tyteca, 2002 [1958], Charteris-Black, 2011). Em específico, sobre o papel da metáfora no alcance desse efeito, pode-se afirmar que, devido a sua função cognitiva e por estar enraizada culturalmente, ela pode levar o auditório a reagir de 
modo emotivo por ativar, como já mencionamos, um sistema de valores e de crenças, o qual funciona como orientador avaliativo, na medida em que está incorporado em uma cultura, na qual determinadas entidades podem ser relacionadas a experiências positivas ou negativas, ou mesmo universais.

Além disso, afirma Kovecses (2003) que as emoções podem ser descritas ou suscitadas por meio de formulações linguísticas diversas. No primeiro caso, o autor assinala que descrições linguísticas são estruturadas pelas metáforas orientacionais (FELICIDADE É PARA CIMA, TRISTEZA É PARA BAIXO), pelas ontológicas (RAIVA É UM FLUIDO QUENTE e AMOR É FOGO), a partir das quais seleções linguísticas são motivadas: fervendo de raiva, ardente de amor, ou mesmo por mapeamentos complexos (RELACIONAMENTO É CONSTRUÇÃO), como ocorre na formulação linguística construção de um relacionamento.

Ainda em relação a esse efeito "Soar certo" e suscitar emoções a partir de um conjunto organizado de estratégias discursivo-metafóricas, salientamos que, ao selecionar o léxico do conflito (Chilton, 2004) - batalha, luta, combate etc. - torna-se possível ao político provocar certas emoções, como, por um lado, sentimentos negativos a respeito de quem é apresentado como inimigo e, por outro, positivos (lealdade, afeição) pelo herói, o qual, geralmente, é o próprio político enunciador. Este efeito é possível, caso sejam evidenciadas no discurso circunstâncias pelas quais o interlocutor encontre identificação e, concomitantemente, orientam-no a ativar domínios conceptuais múltiplos e a construir sentido ao que lhe foi dito.

Nesta parte, interessa-nos retomar alguns pressupostos de Lakoff e Jonhson (2011) de que a mente é inerentemente corporificada, o pensamento é $98 \%$ inconsciente, os conceitos abstratos são, em sua maioria, metafóricos e a racionalidade requer emoção ${ }^{59}$. Portanto, neste viés, o pensamento evolui do sistema neural, sensorial-motor, e as expressões metafóricas são motivadas por metáforas subjacentes oriundas da experiência neural humana em relação a espaço, a movimento, a contenção etc. Por esta razão, pensamento e emoção estão estritamente relacionados. O que ocorre é ora o discurso ser encaminhado de modo mais acentuado ao "parecer certo" ora ao "soar certo"; ambas as estratégias utilizadas a fim de alcançar a persuasão e/ou o convencimento a partir do efeito de "ser certo".

\footnotetext{
59 Essas informações foram obtidas na palestra "Retaking Political Discourse" proferida por Lakoff (2011). Disponível em: http://www.youtube.com/watch?v=UseIJAIxR-4. Acesso em 20 nov. 2012.
} 
Dessa forma, no jogo argumentativo instaurado no campo político em situações de debates de ideias ou, mesmo, diplomáticas, joga-se com os dois campos - racionalidade e emoção - tal como Charteris-Black (2011) ressalta em seu esquema (figura 02, página 132 deste capítulo). Para ilustrarmos como, ao mesmo tempo, torna-se possível selecionar estratégias ligadas à razão e à emoção no discurso político presidencial, procedemos ao exame de um segmento do discurso proferido por Lula em Davos, 2003.

Durante seu pronunciamento, o ex-presidente da República Luis Inácio Lula da Silva defende a tese de haver necessidade de ação política para mudar situações econômicas de ordem internacional - como mais participação de seu governo no comércio internacional, em específico, nas exportações, impedimento de evasão ilegal de recursos etc. - a fim de que se altere o quadro de desigualdade social do mundo e do Brasil. Lula argumenta que seu governo toma diversas medidas com o objetivo de diminuir a miséria do país, no entanto, as relações de comércio internacional vigentes podem impedir o alcance pleno dessas metas.

É possível examinar que o ex-presidente da República apresenta a proposta de ação política mencionada em termos de construção, como ocorre neste segmento (anexo 03),

(7)

A construção de uma nova ordem econômica internacional, mais justa e democrática, não é somente um ato de generosidade, mas, também, e principalmente, uma atitude 65 de inteligência política.

em que a formulação "A construção de uma nova ordem econômica internacional” (linha 63), recategorizada, posteriormente, como "um ato de generosidade" (linha 64) e "uma atitude de inteligência política" (linhas 64-65), encaminha um olhar específico sobre a ação política internacional e seus agentes, qualificando-os com atributos, supostamente, valorizados socialmente. Se levarmos em conta que esses pronunciamentos alcançam um número significativo de pessoas, por ficarem disponíveis no site do governo brasileiro e por serem noticiados pela mídia internacional, podemos afirmar que tais recategorizações reforçam e orientam o auditório geral a ver como pertinente, viável, a ação política proposta, principalmente, a partir dos atributos "atos de generosidade" (linha 65) e "uma atitude de inteligência política" (linhas 64-65).

Assim é que o orador apela à inteligência e à generosidade do auditório, em busca de fazer que este aja conforme o proposto (reconstrução da ordem econômica internacional). 
Além do mais, ao propor, o orador assume os valores e atributos mencionados. Neste exemplo, emoção e razão caminham lado a lado e promovem um olhar direcionado e avaliativo sobre a proposta em questão, colaborando para construir determinada opinião pública a respeito de quem diz (Lula) e para quem ele profere (chefes de Estado ou de governo).

Se a metáfora serve para apresentar justificativas de ações ou de propostas políticas (Parecer certo), reforçar crenças e posicionamentos ideológicos, suscitar respostas emotivas (Soar certo), ainda há de se considerar que tal processo implica a seleção de domínios-fonte que possibilitam a ativação de categorias convencionais já avaliadas pela sociedade e que, por meio delas, o objeto de discurso em foco vai sendo delineado na organização textualdiscursiva; são pistas linguísticas dadas no discurso aliadas a saberes mais gerais (conceptuais), que formam e transformam as referências textuais pelo viés da metáfora.

Dessa maneira, conforme o domínio conceptual ativado, o mesmo objeto de discurso pode ser construído metaforicamente de diversas maneiras conforme a época, o contexto social e o político, podendo despertar reações diversificadas no auditório. Tal como ocorreu com uma proposta de (re)construção, no segmento (7), que foi atrelada à categoria de políticos generosos e inteligentes. $\mathrm{O}$ discurso poderia privilegiar outros caminhos, conforme a domínio-fonte selecionado e as categorias que a partir dele seriam elaboradas por formulações específicas.

Interessa-nos ainda assinalar que Perelman e Olbrechts-Tyteca (2002 [1958]) também discorrem a respeito da possibilidade de o orador alcançar respostas emotivas de seu auditório. Para esses autores, a seleção de ligações simbólicas pode despertar certos sentimentos, como amor ou ódio, desprezo ou veneração, etc. Isto ocorre pelo fato de haver uma relação de participação entre o símbolo e o que ele simboliza, inserida em uma realidade (discursiva) mítica. Neste caso, há possibilidade de se apresentar pessoas ou objetos como símbolos de um determinado grupo ou de algo, de modo a fazer o auditório se unir em prol de algum valor ou de alguma crença.

A bandeira nacional, a cruz, entre outros, são referentes textuais que, ao serem incluídos em dada realidade discursiva, podem levar o interlocutor a reagir com "fervor patriótico ou religioso" (Perelman e Olbrechts-Tyteca, 2002 [1958]) e, assim, ficarem mais flexíveis a aderir a uma tese ou a serem orientados a ver uma situação de maneira específica. Convém ressaltarmos que tal processo apresentado pelos autores da Nova Retórica pode ser 
entendido como metafórico, uma vez que um conhecimento de um determinado domínio é ativado e pode ser associado ao tópico em questão (relação de domínios).

Charteris-Black (2007) aponta a relação simbólica como parte de uma estratégia para alcançar o efeito "Contar a história certa" e orientar argumentativamente. Ele ressalta a possibilidade de se selecionar uma imagem histórica, como a do Tio Sam, para fazer que o interlocutor construa uma imagem de nação unida sentimentalmente.

Além desses pressupostos, outra maneira de utilizar o recurso da relação simbólica consiste de apresentar um membro de um grupo como símbolo dele, um representante. Este procedimento poderá orientar a conduta do escolhido como represente simbólico, pois a imagem que se cria dele será transferida ao simbolizado. Conforme Perelman e OlbrecthsTyteca (2002 [1958], p. 381):

\begin{abstract}
O recurso ao símbolo pode desempenhar um papel eminente tanto na apresentação de premissas quanto no conjunto da argumentação. Presume-se que tudo que diz respeito ao símbolo diz respeito ao simbolizado. E ainda que a relação entre eles não seja estritamente reversível - mas este é um caráter que observamos em todas as ligações, exceto certas ligações formais da argumentação quase-lógica - o símbolo se modifica com seu uso enquanto símbolo. Seja qual for a gênese do vínculo simbólico, geralmente aceito, entre leão e coragem, cada novo uso deste vínculo, na argumentação, confere ao leão certas características e certo valor ligados à coragem.
\end{abstract}

Conforme esses estudiosos, a relação simbólica não pode ser vista apenas como uma analogia. O caráter simbólico dela está ligado fundamentalmente a uma realidade que transcende tempo e espaço. Mesmo quando símbolo e simbolizado estão separados por um intervalo temporal, há entre eles uma ligação indefinível de existência criada no cenário discursivo apresentado.

De modo geral, salientamos que, quando se trata de argumentação, não podemos separar o campo da emoção e o do pensamento. Os dois agem, por vezes, concomitantemente, dado que, se por um lado, o pensamento pode ser direcionado estrategicamente para caminhos não aleatórios a partir da mobilização de certos recursos argumentativos, por outro, há possibilidade de um auditório tocado dialogar com a cena discursiva apresentada de maneira a tomar parte dela para si, vivenciá-la de tal modo que ele se torna parte dos acontecimentos ou, no mínimo, um juiz. 
A respeito de tocar o auditório, ainda afirmamos, com Perelman e Olbrecths-Tyteca (2002 [1958], p. 361), que uma condição prévia de qualquer argumentação consiste de conhecer aqueles que se pretende convencer e/ou persuadir. Como metáfora, discurso e práxis são indissociáveis, é preciso considerar, do ponto de vista argumentativo, que o orador deve encontrar, no exame das características de seu público, pistas que o levem a selecionar os argumentos mais adequados e, neste processo, a seleção da metáfora também está incluída, como passamos a discorrer.

\subsection{Argumentação e metáfora conceptual: usos estratégicos do discurso político}

Pesquisas vêm demonstrando (Charteris-Black, 2006, 2007, 2008, 2009, 2011; Moreno, 2008; O’Brien, 2003; Chilton e Schãffner, 2002, entre outros) diversas ocorrências de metáforas conceptuais em pronunciamentos feitos por políticos, entre eles, os chefes de Estado. Isto pode ser considerado um indício significativo de a seleção metafórica possuir força argumentativa tanto por ativar modelos cognitivos compartilhados cultural e socialmente, quanto por despertar sensações e compreensões advindas da corporalidade, as quais utilizamos para entender aquilo que nos cerca, conforme os pressupostos da TMC apresentados no primeiro capítulo deste trabalho.

A fim de procedermos à discussão sobre os efeitos que a metáfora pode suscitar e como estes estão ligados à argumentação do discurso político, observemos o seguinte segmento do pronunciamento do ex-presidente da República Luis Inácio Lula da Silva no $4^{\circ}$ Fórum Global de Corrupção, ocorrido em Brasília, em 7 de junho de 2005 (Anexo 12), atentando-nos às partes em destaque:

(8)

Estamos conduzindo um grande projeto de transformação social que assegurará um longo ciclo de desenvolvimento sustentável, ampliando nossas fronteiras sociais,

180 aprofundando a democracia e garantindo um novo lugar para o Brasil no mundo. Tenho, ademais, uma biografia a preservar, um patrimônio moral, uma história de décadas em defesa da ética na política. Por isso, não iremos acobertar ninguém, seja quem seja que esteja envolvido.

No dia de hoje, determinei aos ministros uma solução definitiva para os

185 problemas envolvendo os Correios e o Instituto de Resseguros do Brasil, resultando no afastamento dos diretores de ambas as instituições, sem prejuízo da continuidade das investigações. Digo que cortaremos na própria carne, se necessário. Sem prejulgar ninguém, e respeitando o direito a defender-se, que todo 
cidadão ou cidadã possui, não vamos vacilar um segundo na defesa do interesse $\mathrm{d} a$ coisa pública.

Consideramos que examinar a língua em uso é entendê-la como produto social, cujo papel de construção do conhecimento, de organização e de compreensão da sociedade é significativo. Ao mesmo tempo em que o falante toma para si o universo de uma língua e com ele constrói mundos discursivos, ele também é tomado por este universo pré-constituído histórico e culturalmente. Isto quer dizer que o homem herda uma língua não neutra e, por meio dela, relaciona-se com a realidade empírica. Na prática social, o discurso dialoga com outros e, neste diálogo contínuo, é possível falar sobre objetos que já foram julgados e categorizados de um modo não rigidamente estável, mas por algum motivo legitimado, reproduzido e propenso a ajustes, caso tais modificações sejam permitidas socialmente e estejam alinhadas aos propósitos enunciativos e aos lugares discursivos de um orador que a elas recorre.

A metáfora também faz parte desse processo, a ele se funde, constitui e é constitutiva do universo dessa língua. Como herança das experiências de um ser social e histórico - que aprende consigo e com o outro - por meio dela, é possível atribuir sentidos ao mundo, na medida em que pensamento, emoção e sensação também mediam a relação estabelecida entre o homem e aquilo a que ele atribui sentido.

Por conta disso, não é de duvidar que boa parte dos brasileiros, a maioria provavelmente, compreenderia a formulação linguística "Digo que cortaremos na própria carne, se necessário" (linhas 187-188), enunciada no discurso proferido pelo ex-presidente da República Luis Inácio Lula da Silva, no $4^{\circ}$ Fórum Global de Corrupção, em 2005, como já mencionamos à página 129. A ideia de um só corpo, uma só carne, além de estar presente em discursos diversos, como no religioso, traz em si um conhecimento partilhado oriundo da experiência humana com seu próprio corpo, pelo qual a compreensão do sentido de unidade relacionado a Lula e ao PT é orientado. A tentativa de trazer para perto do auditório cidadão brasileiro e políticos/empresários do exterior - uma imagem de um organismo, que pode não estar saudável, é um modo de dar sentido a uma determinada situação vista como um problema moral e apresentar uma solução possível: a mutilação de uma parte do corpo.

Nesse processo de construção de sentido, o conhecimento da dor é fundamental para a compreensão da afirmação da mutilação, do sacrifício. Esta, por sua vez, é uma maneira de 
promover o efeito de uma atitude dolorosa por parte de Lula: a de punir os petistas envolvidos, na época, nas denúncias de corrupção, se estas se comprovassem, como aconteceu sete anos depois, em 2012. Ao mesmo tempo, o conhecimento de outros discursos possibilita relacionar à ideia de sacrifício associada à história do Partido dos Trabalhadores (PT), crenças e valores pertencentes ao cristianismo, que é dominante no Brasil.

Seguindo nessa direção, temos que o objeto de discurso "a própria carne" dá a conhecer o processo de referenciação pelo viés da metáfora ontológica e da orientacional (Cf. capítulo I, p.36-40). Em relação à primeira, ela viabiliza, por meio da ativação de referência dupla - corpo humano, Partido dos Trabalhadores - a elaboração mental do Partido dos Trabalhadores associados pela noção de corpo. Assim é que uma experiência sensorial (primária), tal como discutimos à página 38 deste trabalho, relacionada à dor é ativada e permite que o auditório entenda o que o orador propõe como sentido a respeito da reação que Lula teria, se houvesse comprovação das denúncias de corrupção.

Já a metáfora orientacional pode ser examinada na seleção "própria", de modo a permitir uma visualização espacial, em que Lula se apresenta como pertencente do partido PT, mesmo ao falar como chefe de Estado. Tal observação respalda-se no pressuposto de Lakoff e Johnson (1980), que discutimos no primeiro capítulo deste trabalho, à página 36, no qual se afirma que a visão de mundo (posicionamento) pode ser marcada no discurso por meio da ideia de orientação corpo e espaço.

Como também, relacionamos esse procedimento à estratégia argumentativa apresentada por Perelman e Olbrechts-Tyteca (2002 [1958]) a respeito de a imagem de uma pessoa ser relacionada ao seu grupo e vice-versa. Os estudiosos salientam que há possibilidade de se agir no discurso, a fim de promover efeito de aproximação ou de ruptura. Neste último caso, o orador afasta-se de determinados membros de seu grupo, por considerar certas atitudes como inadequadas aos valores da maioria. Entendemos que é assim que ocorre no segmento (08).

Além do mais, tendo em vista que a apresentação de um antimodelo pode suscitar um efeito repulsivo e de distanciamento, como também já destacaram Perelman e OlbrechtsTyteca (2002 [1958]), há de se considerar que era preciso distanciar-se de alguns comportamentos, para se aproximar de outros, defendidos pelo Partido dos Trabalhadores (PT), que atuava até então como oposição. 
Nesse viés, compreendemos que o processo de referenciação colabora para se constituir a ideia de unidade - ex-presidente e Partido dos Trabalhadores - e, com isto, pode favorecer o efeito de verossimilhança do discurso, uma vez que dificilmente o auditório separaria a imagem de Lula à do partido. Foi assim que o orador procedeu argumentativamente, optou por assumir sua representatividade no PT e por reagir a partir do desligamento de alguns políticos petistas acusados.

Ainda relacionamos esses posicionamentos às estratégias de ligações de solidariedade. Nesta direção, dizem Perelman e Olbrechts-Tyteca (2002 [1958]) que alguns argumentos se sustentam a partir da noção de solidariedade entre juízos admitidos e outros que se procura promover. A argumentação, embasada a partir desse tipo de acordo, procura unir elementos diversos como partes indissociáveis. Tal efeito pode ser alcançado, caso sejam postas em evidência as causas e os feitos de determinadas ligações. Ao seguir por este caminho, torna-se possível aderir a três tipos de argumentos: o que tende a ligar dois acontecimentos (incluindo a ideia de princípios), ou mais, por meio de um vínculo causal; o de expor a causa que determina dado acontecimento; o de evidenciar o efeito do acontecimento. Assim, pelo vínculo causal, buscam-se as causas de um ato e indicam-se os efeitos e as finalidades.

No caso do segmento (08), entendemos que o orador busca aproximar-se dos cidadãos brasileiros, permitindo que estes reconheçam os princípios morais do ex-presidente, que se mostra apto a agir de modo doloroso, caso as causas do acontecimento em evidência (corrupção) fossem relacionadas à atitudes inadequadas de algum membro do PT. Neste viés, temos que o efeito de um dado acontecimento tem por base a ideia de que todo ato conduz a uma sanção positiva ou negativa, que deve ser dada por alguém que possui o poder de agir e sancionar. Assim, no encaminhamento do discurso de Lula, ainda, pode-se afirmar que a maneira como o orador sanciona atitudes de corrupção orienta o auditório a chegar a um juízo tanto ligado à recompensa do orador quanto à punição dos culpados.

Nessa direção, em razão de o auditório desse discurso (segmento 08) também ser composto por políticos do exterior, entendemos que a apresentação do sucesso de um Estado implica expor o bom desempenho de certos grupos profissionais e políticos, tal como é o caso de imprimir confiabilidade à figura do ex-presidente e de seu governo. Com efeito, tratase de convalidar uma imagem de competência, que pode ser atribuída ao cumprimento de atividades futuras, tal como parcerias comerciais entre países. Sendo assim, assegura-se a 
ideia de compromisso a partir do efeito de um ato passado responsável por um desdobramento favorável, que é o de se distanciar dos corruptos e ficar ao lado do povo.

Assim é que esse argumento recai sobre o uso de valores, a fim de recorrer a juízos norteadores de sanções múltiplas. Proceder a esse tipo de orientação consiste de pôr o auditório a par de situações e suas consequências, enviesadas axiologicamente, para que ele tome certas decisões, podendo, assim, ser utilizada para justificar comportamentos e, também, indicar posturas pelo viés da adequação ou da inadequação. Nesta direção, em razão de esse discurso ter sido elaborado em uma situação política de conflito, em que muitos relacionavam as denúncias de corrupção à figura do fundador do Partido dos Trabalhadores, construir o PT como um corpo e Lula como membro-cabeça, que detém o poder de decisão, é atitude alinhada à tese de que o ex-presidente faria justiça e estava do lado do povo brasileiro, de seus direitos (“a coisa pública", às linhas 189-190).

Pode-se afirmar, portanto, que a seleção da metáfora PT É UM CORPO, descrita pela formulação "Digo que cortaremos na própria carne, se necessário" (linhas 187-188) e utilizada como réplica, feita a distância, é pista indicativa de que o ex-presidente privilegiou a manutenção da relação entre ele e o cidadão, numa tentativa de se manter no poder e estabelecer controle sobre a situação, já que construir relacionamentos fortes com o povo consiste de um fator essencial na prática política, na qual a legitimidade é dada pela instância cidadã. Portanto, a seleção dessa metáfora revela uma orientação argumentativa singular, se relacionada à figura de quem a pronunciou e ao momento enunciativo.

Relacionamos tal procedimento discursivo-metafórico e a seleção do léxico "carne" feita pelo ex-presidente da República Lula ao pressuposto de Aquino (2003, p. 199) sobre a argumentação no discurso político:

Muito mais do que formular um enunciado que se reconheça como uma resposta a uma questão, o uso de determinados elementos selecionados pelos interlocutores pode criar um contexto em que se instaure uma força pragmática que condiciona a atividade do interlocutor e o faz agir em direção ao que não tinha pensado fazer. Nessa acepção, a seleção do léxico pode encaminhar, implicitamente, para o controle e a imposição.

É assim que entendemos que a formulação "cortaremos na própria carne" possibilita construir um modelo mental favorável da atitude de Lula e instaurar força pragmática, de 
maneira tanto a direcionar a ideia de que ex-presidente não estava envolvido com corrupção quanto a conhecer o sacrifício e a dor enfatizados pela formulação metafórica. Temos, pois, o apelo à moralidade que fundamenta o posicionamento evidenciado.

Seguindo nessa direção, metáforas postas em discurso consistem em evidências de uma atitude política de construir situações específicas de acordo com as normas de uma sociedade, que são produzidas histórico e culturalmente, e com os interesses que estão em jogo. Isto porque a argumentação política tem também como finalidade construir relações de cooperação e de acordo com diversos grupos - político e cidadão, político e político, Estado e Estado etc. Para que isto ocorra, existem vários fatores, entre eles, a imagem de credibilidade do orador construída por meio de um processo de identificação de interesses e da apresentação de ações vistas como coerentes. Instâncias sociocognitivas convencionais podem colaborar para esses propósitos, uma vez que encaminham maneiras de ver determinados objetos de discurso de tal modo que criam um efeito de a conclusão ter sido alcançada, especificamente, pelo auditório.

A seleção "patrimônio moral", apresentada no discurso proferido por Lula, reforça tal pressuposto tanto pelo fato de o povo buscar um representante, cuja imagem construída deve estar alinhada a atitudes de cunho moral, quanto em razão de os políticos do exterior precisarem crer em seus aliados. É nesta direção que o pronunciamento segue, a fim de manter legitimidade, e a metáfora favorece esse encaminhamento por estruturar a noção de moralidade. Para Lakoff e Johson (1999), este termo corresponde à ideia do bem viver humano, ou melhor, a sua preocupação com o que é melhor para viver bem. Muitos dos conceitos morais são fundamentados por metáforas oriundas da natureza de nossos corpos e das interações sociais. Isto quer dizer que nossas experiências, tanto com aquilo que nos provoca bem-estar, principalmente físico, quanto com a cultura historicamente constituída, orientam-nos a conceptualizar a moralidade, isto é, o viver bem.

Por conta disso, as pessoas preferem saúde à doença, liberdade à escravidão, força à fraqueza, ar puro em vez de contaminado, dominar do que ser dominado, entre outros. Os autores assinalam que (op. cit., p. 291): “[...] uma vez que a maioria das pessoas acha melhor ter riqueza suficiente para viver confortavelmente do que ser pobre, nós não ficaríamos surpresos de encontrar que bem-estar é conceptualizado como riqueza" ${ }^{\text {60 }}$. Um presidente da

\footnotetext{
${ }^{60}$ Tradução livre: [...] since most people find it better to have enough wealth to live comfortably than to be impoverished, we are not surprised to find that well-being is conceptualized as wealth.
} 
República, logo, deve promover a ideia de agir em prol daquilo que uma comunidade cultural privilegia como moralidade. Pelo menos, é isto que se espera de um chefe de Estado.

Nesse viés, a moralidade está presente nos discursos políticos e seu emprego tem o papel de buscar identificação com o auditório, bem como sua aprovação. Lakoff (2002) observou a presença de metáforas pelas quais os políticos evocavam questões de ordem moral e detectou que, por exemplo, os políticos conservadores utilizam a ideia do Estado como pai de uma família tradicional, na qual ele cumpre o papel central de apoiar e de proteger os outros membros e, ao mesmo tempo, de definir regras, de oferecer compensações ou punições. No caso do pronunciamento feito por Lula, a tentativa de fortalecer uma imagem de um representante que cuida dos interesses do povo, de seu bem viver, e que está disposto ao sacrifício também revela o uso da metáfora e do discurso como um meio de conseguir o controle de uma situação política, numa tentativa de levar o auditório a identificar atributos morais, julgados essenciais à figura pública do ex-presidente.

Nessa direção, a metáfora posta no discurso possibilita a mobilização de saberes diversos - da experiência corpórea, de fatores culturais, sociais, históricos, éticos, morais que se ajustam a cada situação de interação. Assim, embora saibamos que a metáfora está presente em práticas da linguagem no campo político e sua ativação pode ser entendida como estratégica, como o discurso o é, parece-nos coerente afirmar que seu uso caracteriza-se por ser semelhante em termos de ativação e associação de alguns domínios-fonte ${ }^{61}$, já que os políticos aprendem a proceder discursivo e linguisticamente por meio de suas experiências na prática política e recebem influência dos discursos do cotidiano. Ao mesmo tempo, entendemos que os efeitos promovidos por essas ativações são singulares, em razão de estas dialogarem com as características específicas do momento da enunciação, como a cultura, as regras pré-estabelecidas em um determinado grupo, os posicionamentos assumidos pelos participantes, a época etc.

Nesse viés, Charteris-Black (2011) afirma que os políticos não são poetas e, por conta disto, costumam selecionar metáforas familiares, isto é, as convencionais, as quais, geralmente, são aprendidas a partir também de experiências na política. Em relação a seleções metafóricas criativas, ou novas, o autor afirma que estas tendem a se tornar convencionais quando usadas no discurso político, por apresentarem um modo rápido de se referir e atribuir sentido a determinados objetos de discurso, cujos conceitos costumam ser complexos. Além

\footnotetext{
${ }^{61}$ Consideramos que a seleção de alguns domínios-fonte se repetem por estarem disseminados na prática política da linguagem e recebem ajustes da configuração do encontro.
} 
do mais, ressaltamos que muitos termos linguísticos com sentido metafórico selecionados por políticos são disseminados por receberem destaque na mídia, que divulga e constrói opinião e também cumpre o papel de mediar e dar sentido ao mundo não imediato da política, em âmbito nacional e também global.

Em geral, entre as possibilidades de dizer, o político pode orientar olhares e direcionar conclusões, ao selecionar mapeamentos complexos ou ao fazer uso de nossas experiências corpóreas - como nossas percepções sensoriais - para se referir e construir de maneira metafórica versões públicas de situações político-sociais e dos agentes que nelas estão envolvidos de modo a se aproximar do auditório, já que, como afirma Charteris-Black (2011), o discurso torna-se persuasivo quando, por meio dele, evocam-se conhecimentos partilhados, isto é, familiares àqueles para quem a argumentação é dirigida ${ }^{62}$.

Ao selecionar determinada metáfora, um domínio-fonte é ativado, relacionado a determinada circunstância e descrito por meio de formulações linguísticas, como as referenciais, pelas quais construções discursivas avaliativas são motivadas e podem orientar argumentativamente o auditório de tal modo que este se torne disposto a tomar certas decisões em vez de outras. Isto porque o domínio conceptual selecionado, caso seja conhecido pelos interlocutores, possibilita associações específicas de domínios conceptuais ligadas diretamente a um conjunto de crenças e de valores que motivam a constituição de efeitos de verdade. Tratam-se de bases axiológicas pré-determinadas em um modelo mental as quais são partilhadas. Isto quer dizer que ocorre mais do que uma associação de imagens, a metáfora viabiliza transposição de valores, importantíssimos para a argumentação, se forem reconhecidos como legítimos.

Nesse viés, ao tratarmos da argumentação - ação dada no e pelo discurso e modificadora de meios (Aquino, 1997) - consideramos seu imbricamento no processo cognitivo, na medida em que o orador precisa ativar certos conhecimentos e, em consequência, o auditório necessita reconhecê-los, e pelo fato de a modificação de um contexto cognitivo, o convencimento ${ }^{63}$, consistir em um propósito argumentativo. Logo, as metáforas conceptuais, que permeiam nosso pensamento, quando postas em discurso e

\footnotetext{
${ }^{62}$ Perelman e Olbrechts-Tyteca, 2002 [1958] já assinalaram em seu tratado.

${ }^{63}$ A partir dos pressupostos da Nova Retórica de Perelman e Olbrechts-Tyteca (2002 [1958]), convencer corresponde a um tipo de manipulação cognitiva, à ação de levar o outro a acreditar. Já a ação de persuadir baseia-se no fazer que o interlocutor aja de uma determinada maneira. Tais propósitos estão, de certa maneira, interligados e podem ser interdependentes. Conforme esses autores (op. cit., p.30): "Para quem se preocupa com os resultados, persuadir é mais do que convencer, pois a convicção não passa da primeira fase que leva à ação. [...] Em contrapartida, quem está preocupado com o caráter racional da adesão, convencer é mais do que persuadir".
} 
enfatizadas nos processos de referenciação, tornam-se significativas para a argumentação, principalmente, em situações em que se quer alcançar pessoas de diversas culturas, como ocorre nos encontros entre chefes de Estado e de governo.

Souza (2010) afirma que os estudos da argumentação, que implicam o exame da ação motivada, também requerem um olhar tanto sobre a experiência de um indivíduo quanto a respeito da natureza humana (mente, cognição, desejo), tendo como pressuposto a ideia de o comportamento ser causado por pensamentos e por sentimentos, próprios da hereditariedade, e pelo ambiente. Neste viés, o estudioso retoma os estudos de Pinker (2004, p. 19) para quem:

Todo mundo precisa prever o comportamento dos outros, e isto significa que todos nós necessitamos de teorias sobre o que motiva as pessoas. Uma teoria tácita da natureza humana - a de que o comportamento é causado por pensamento e sentimento - está embutida no próprio modo como pensamos sobre as pessoas.

Agir pelo discurso a fim de conduzir o outro a pensar, a sentir, a fazer implica, portanto, a mobilização cognitiva do orador, que pensa e constrói o seu auditório de certo modo e toma atitudes discursivas a partir disto. Neste processo, o argumentador busca orientação para o seu próprio agir e, embora seja um desafio descobrir ou pressupor o que pode levar alguém a tomar uma atitude ou a se comportar de alguma forma (Souza, op. cit.), o fato é que há tentativas diversas - de ordem discursivo-cognitiva - de orientar pensamentos e sentimentos de um determinado público, assim como entendemos a presença da metáfora nos processos de referenciação, foco deste trabalho.

De acordo com Charteris-Black (2011), a observação de alguns discursos de políticos considerados bem sucedidos revela a tendência de eles combinarem apelos de ordem cognitiva e emocional na tentativa de apresentarem olhares sobre situações político-sociais de modo crível. Geralmente, esses locutores constroem uma dramatização relacionada à circunstância do presente enunciativo, apresentam possíveis soluções e fornecem explicações, pelas quais avaliações específicas tendem a ser favorecidas, a fazer que os interlocutores fiquem convencidos de que, por exemplo, esses políticos são melhores e mais fortes do que os adversários. 
Pode-se dizer ainda, como assinala Charteris-Black (2011), que tal procedimento corresponde a uma motivação retórica ${ }^{64} /$ argumentativa - que provoca efeitos no interlocutor em relação às suas expectativas sobre o futuro - em que construções discursivas específicas de fatos passados são relacionadas ao presente enunciativo de modo a fortalecer a proposta de um futuro melhor. A respeito disto, é possível afirmar que, na prática política, está implicada a ideia de orientar decisões sobre mudanças, isto é, motivar a decisão de transformar ou não um estado de coisas. Isto pode ser orientado a partir do modo como o político constrói situações sociais e políticas do presente e do passado, em seus discursos, e, consecutivamente, seus efeitos no futuro.

\subsubsection{Motivação retórica/argumentativa pelo viés da metáfora conceptual}

Reportemo-nos à retórica clássica, em que Aristóteles afirmara que no discurso político, ou deliberativo, são debatidas decisões a respeito de ações futuras, como, por exemplo, o modo de atingir a paz ou a guerra. Tal caracterização, ainda presente nos discursos políticos, leva-nos a discutir de que modo a proposta de mudança, apresentada a fim de conseguir que o auditório opte por determinada decisão, torna-se motivação retórica/argumentativa, tomando como ponto de partida que o efeito da proposta (futuro), isto é, o modo como o auditório a entende, é fundamental para o alcance da adesão.

Nessa atitude de criar e de transformar realidades empíricas diversas no e pelo discurso, o político tende a construir o que poderá vir a existir e o que existe anterior ou concomitantemente ao momento do dizer. A compreensão das propostas apresentadas no discurso, neste viés, dá-se a partir do modo como os indivíduos entendem o mundo, o lugar que eles ocupam nele e da maneira como pensam sobre o tempo, já que suas experiências em determinados eventos e suas expectativas daquilo que virá acontecer relacionam-se às noções de tempo e de espaço.

A essa atividade discursiva e cognitiva que dá possibilidade ao político de falar sobre objetos existentes ou não no instante em que o discurso é elaborado ou pronunciado, relacionamos o pressuposto de Lakoff e Johnson (1999) que afirmam haver uma noção metafórica $^{65}$ (orientacional e ontológica) que orienta a compreensão de tempo e,

\footnotetext{
${ }^{64}$ Conforme Guimarães (1997), argumentação e retórica são consideradas, praticamente, como sinonímias nos estudos da atualidade. Neste trabalho, adotamos os termos sob essa concepção.

${ }^{65}$ Embora não nos debrucemos sobre a questão da metonímia, julgamos significativo dizer que Lakoff e Johnson (1999) também mencionam a respeito da noção metonímica de tempo.
} 
consecutivamente, de espaço. Para estes estudiosos, as pessoas não observam o tempo a partir de um conceito metafísico ${ }^{66}$, mas sim examinam os eventos e os comparam, definindo tempo por meio de um processo metonímico, em que sucessivas repetições de um tipo de evento representam intervalos de tempo.

A noção de tempo é metafórica, porque a construímos a partir dos movimentos feitos em um determinado espaço em que estamos situados - pensamento linear; a compreensão do tempo, pois, pressupõe uma noção de movimento no espaço. O sentido metafórico de tempo básico corresponde àquele em que um indivíduo observa o momento presente a partir do lugar em que ele está (PRESENTE É AQUI), enquanto o passado e o futuro são compreendidos por associação, respectivamente, ao que está atrás (PASSADO É ATRÁS) e à frente dele (FUTURO É À FRENTE). Neste viés, assinalam Lakoff e Johnson (1999) que a orientação metafórica de tempo corresponde à noção de espacialização e consiste: no lugar do Observador $^{67}$ (presente), no espaço à frente do Observador (futuro), no espaço atrás do Observador (passado).

Embora essa noção de tempo esteja presente em várias línguas, Lakoff e Johnson (1999) ainda assinalam que, em algumas, o passado é relacionado à frente. Isto ocorre com o idioma chileno da Cordilheira dos Andes, o Aimará. Nele, existe a metáfora O PASSADO É À FRENTE, que é fundamentada pela experiência do indivíduo de ser capaz de ver, em sua frente, os resultados daquilo que ele fez. A expressão linguística que indica tal metáfora é Mayra (olho, visão frontal) Pacha (tempo), que, na verdade, refere-se ao tempo passado. Em contrapartida, o tempo futuro corresponde a Q'ipa Pacha, isto é, tempo que está de volta, está para trás, apresentando a metáfora FUTURO É PARA TRÁS.

De todo modo, nesses casos, o domínio-alvo tempo ${ }^{68}$ tem como domínios-fonte as noções de espacialização e também de movimento, embora os mapeamentos recebam ajustes da experiência cultural dos indivíduos. Neste viés, o Observador do tempo em movimento pode estar parado ou, vice-versa, ele pode se movimentar, enquanto o que está parado é o tempo. Os dois casos podem ocorrem simultaneamente em uma mesma formulação linguística, uma vez que estão inter-relacionados e equivalem a uma metáfora central PASSAGEM DO TEMPO É MOVIMENTO.

\footnotetext{
${ }^{66}$ Para os estudiosos, há uma área no cérebro (sistema visual) apenas para a detecção do movimento; não existe área específica para deteç̧ão do tempo.

${ }^{67}$ Termo utilizado por Lakoff e Johnson (1999) a partir de um ponto de vista cognitivo. O "O" em letra maiúscula significa que a palavra é utilizada em nível abstrato.

${ }^{68}$ Lakoff e Johnson $(1980,1999)$ também identificaram outras metáforas conceptuais de tempo, como: TEMPO

É RECIPIENTE, TEMPO É RECURSO LIMITADO, TEMPO É DINHEIRO.
} 
Quanto ao primeiro, como já dissemos, o tempo é conceptualizado como objeto em movimento - sendo que o presente é sempre relacionado à locação do indivíduo - e recebe uma orientação (frente, trás). Em outras palavras, o objeto-tempo movimenta-se em direção a um Observador parado, que é o centro dêitico ${ }^{69}$; o que está passando pelo observador é o presente, e o que passou, o passado. No segundo caso, o Observador está em movimento e vai em direção ao tempo. Isto equivale dizer que o tempo é parado, locado em áreas delimitadas, e o Observador desloca-se por essas áreas (do presente ao futuro). Pode-se afirmar que, por meio deste último, torna-se possível criar o efeito de uma pessoa que tem atitude.

Se as noções de tempo e de espaço estão correlacionadas e implicam a ideia de (falta de) movimento, de ações, pode-se dizer que, quando o político apresenta suas propostas, organizando, categorizando situações político-sociais e apresentando-as em espaços e tempos definidos no discurso, ele procede a motivar seu auditório de modo metafórico e a buscar, como denominado pela retórica, lugares comuns a partir dos quais o olhar do auditório pode ser fixado em uma direção específica. Não se trata de criar um mundo de coisas inexistentes ou não, mas sim de construir discursiva e cognitivamente relações vistas como possíveis e coerentes, validadas pelas sensações orientadas também pela metáfora conceptual.

Assim, partindo dessa perspectiva de Lakoff e Johnson (1999) de que os indivíduos entendem o tempo também em termos de movimento e pela percepção de mudança, de transformação (transformação do tempo e, consecutivamente, de circunstâncias sociais, pessoais, políticas), e levando em conta que a mudança corresponde a um tópico discursivo recorrente no discurso político - ora construindo-a como algo necessário e positivo, ora como negativo e perigoso - a motivação retórica/argumentativa implica o modo como o orador seleciona em seu discurso formulações que ativam essa orientação (passado, presente e futuro). Provocar a ação do outro, em alguns contextos culturais, significa fazê-lo entender que determinada direção o levará a um estado de coisas futuras promissoras, ou seja, que ele encontrará em sua frente condições que o agradam de certo modo. A respeito disto, no exame da argumentação política, julgamos importante observar em qual marco espaço-temporal discursivo-cognitivo é apresentado o objeto de discurso e como ele é avaliado.

Apenas para ilustrarmos tal pressuposto, observemos as partes em destaque dos seguintes segmentos do discurso proferido por Lula em Portugal, no seminário “Oportunidades de Novos Negócios e Investimentos Brasil-Portugal” (anexo 8):

\footnotetext{
${ }^{69}$ Visão egocêntrica do ser humano.
} 
(9)

Estou convencido de que as perspectivas para as nossas relações econômicas e comerciais nunca foram tão favoráveis. Sei que nossos parceiros portugueses estão bem informados sobre o Brasil. Somos, hoje, o segundo principal destino dos investimentos de portugueses.

35 Isso é prova concreta de que nossas relações ultrapassaram a etapa dos discursos bem-intencionados. Abrem-se agora, novas oportunidades de investimentos no Brasil.

$[\ldots]$

120 A ousadia e o engenho de nossos antepassados serão sempre fonte de inspiração para a nossa associação. Vencemos oceanos e unimos continentes e povos. Construiremos, agora, as pontes de uma nova cooperação, mais densa e madura. $O$ vento é favorável e, como disse um dos poetas maiores da nossa língua portuguesa, "navegar é preciso" [...]

Como mencionamos às páginas 88-89 do capítulo 2, na política internacional, é preciso promover uma imagem pública positiva do Estado, manter relações diplomáticas com outros governos estrangeiros e também criar parcerias, a fim de satisfazer os interesses econômicos, políticos e sociais do país. Por isto, estabelecer relações bilaterais consiste de uma das metas das visitas oficiais e corresponde a tentativas de se chegar a acordos para manter, fortalecer, ou mesmo, criar alianças com outros Estados. No anexo 08, às linhas 3137, que é parte do exórdio do pronunciamento de Lula, este já inicia de maneira a indicar as perspectivas positivas (efeitos) da relação Brasil-Portugal. Mais do que isto, o Brasil é construído como destino de Portugal: “o segundo principal destino dos investimentos de portugueses" (linhas 33-34). Tal procedimento indica uma noção de movimento feito por dois agentes ("Brasil", "destino de investimento de portugueses", "nossos parceiros portugueses"), os quais evoluíram em relação à parceria, ultrapassaram etapas ("nossas relações ultrapassaram a etapa dos discursos bem-intencionados") e dificuldades ("Vencemos oceanos e unimos continentes e povos") e seguem para o alcance do objetivo comum, que é o progresso econômico mútuo.

Nesse segmento, logo, podemos examinar a presença de uma metáfora que estrutura a noção de parceria bilateral e orienta a necessidade de ação mútua dos agentes envolvidos (Brasil e Portugal), que é o conceito de jornada. Portanto, temos RELAÇÃO BILATERAL É JORNADA A DOIS como ideia de movimento de corpos em uma determinada noção espaçotemporal com objetivos comuns. 
Além do mais, julgamos significativo salientar que a maneira pela qual a imagem do Brasil é orientada no segmento é relacionada ao momento presente da enunciação ("hoje", "agora"), que reforça a autopromoção de governo e de governante como aqueles que se movimentaram (2003-2005) e agiram para transformar o país no "destino de investimentos portugueses". Outras metáforas foram selecionadas e possibilitaram ao orador recriar, recategorizar os agentes e ativar outros objetos de discurso, como a da construção (RELAÇÃO BILATERAL É CONSTRUÇÃO A DOIS), a partir da seleção "Construiremos, agora, as pontes de uma nova cooperação, mais densa e madura" pela qual é estruturada a proposta de ação e seus efeitos futuros, indicada durante o desenvolvimento do pronunciamento, conforme examinaremos em nossas análises.

Assim, a metáfora pode ser uma maneira de provocar ou de intensificar uma imagem de coerência às ações do político, quando empregada na indicação de suas propostas e justificativas. Mapeamentos complexos, produtos da relação de um domínio-fonte correspondente, por exemplo, à jornada etc. e um domínio-alvo de processos políticos e de agentes, também dão condições para que os interlocutores construam as etapas e o final a partir de um viés, pelo qual a tese do discurso pode ser reforçada, tal como foi possível examinar no segmento apresentado.

Relacionamos essa discussão - a tentativa do político de fazer o outro agir a partir do que lhe é proposto em termos de efeitos futuros e que pode ser motivada por conceitos estruturados associados a movimentos, a ações, a ideia de espaço e de tempo - à argumentação ligação à direção, utilizada para apresentar uma meta ou indicar meios que ajudam a chegar a um determinado objetivo. À formulação da proposta, em termos argumentativos, está atrelado o modo de organização da apresentação das etapas (indicação de ações); isto porque cada fase da argumentação consiste de um momento significativo em que o orador pode conseguir modificar a disposição de seu auditório, assim como afirmam Perelman e Olbrechts-Tyteca (2002 [1958], p.322): “estando transposta uma primeira etapa, os interlocutores se acham diante de uma nova configuração da situação, que lhes modifica a atitude ante o resultado final".

Em consonância aos pressupostos de Perelman e Olbrechts-Tyteca (2002 [1958]), interessa-nos destacar que o argumento ligado à direção difere do relacionado ao receio do precedente. Neste caso, há tentativa de mostrar a necessidade de se opor a uma dada atitude, motivando um temor à repercussão de ações e efeitos futuros. Ambas as estratégias - direção e receio do precedente - podem coexistir e serem selecionadas, por um lado, para qualificar as 
propostas do orador, valorizando-o e, por outro, para desqualificar outros agentes sociais e políticos. A metáfora da guerra, por exemplo, pode incitar no auditório o receio de um efeito futuro e fazê-lo agir a fim de evitar uma calamidade.

Ao agir argumentativamente a partir de um viés da mudança, é possível que o orador construa um estado de coisas presente de modo desqualificado - objetos de discurso relacionados a políticos adversários costumam entrar no processo - a fim de validar a necessidade de um líder político com força para agir, isto é, um agente de mudanças promissoras. Salientamos que este foi o caso do ex-presidente Lula que, nas campanhas eleitorais, reforçou a promessa de um futuro diferente para o Brasil (nacional e internacionalmente), baseado nas propostas do Partido dos Trabalhadores (PT) ${ }^{70}$.

Fato é que, quando o político tem o propósito de modificar determinada situação, como ocorre em situações em que o orador almeja fazer parte de um grupo historicamente restrito (por exemplo, a ONU), criar processos políticos vistos como inovadores, mudar hábitos de um povo, criar alianças etc., é preciso uma série de argumentos que validem a proposta. Isto porque motivar o outro a agir para modificar um determinado estado de coisas consiste, em boa parte das vezes, em um processo complexo. A seguinte afirmação de Paulhan $^{71}$ imprime o porquê da necessidade da justificativa da mudança:

Fácil encontrar razões para os atos singulares, difícil para os atos comuns. Um homem que come carne de vaca não sabe por que come carne de vaca; mas, se trocar para sempre a carne de vaca pela salsífi ou pelas rãs, não o fará sem investigar mil provas, umas mais eruditas do que as outras.

Entendem os autores da Nova Retórica que uma opinião ou um estado de coisas habituais e regulares são mais aceitos, porque fazem parte da inércia psíquica e social das pessoas. Por tal motivo, os membros de uma sociedade presumem que algumas condutas e certos modos de pensar continuarão no futuro, quer seja por hábito quer pela condição aparente de coerência. A mudança, logo, requer uma mobilização de argumentos que a justifiquem, ou seja, diversas razões para convencer da necessidade de ruptura. Mesmo assim, existe a possibilidade de objeção por parte do auditório. Nestas situações, caso a

\footnotetext{
${ }^{70}$ Examinamos as propostas de Lula em relação à política externa de seu governo no capítulo 2 deste trabalho.

${ }^{71}$ PAULHAN, Jean (1930). Lê guerrier appliqué. Paris: Gallirmard. Apud. Perelman e Olbrecths-Tyteca (2002 [1958], p. 120)
} 
mudança seja efetivada, ela poderá ser vedada pelo orador, que desenvolverá um discurso pelo qual privilegiará um efeito de normalidade que atenda à necessidade da inércia social.

Em termos cognitivos, para Lakoff e Johnson (1999, p.556), por conta de os sistemas conceituais do homem ser, em sua maioria, inconscientes e o neural fixo, mudar um conceito consiste de um processo lento e difícil. Isto porque "não podemos alterar, livremente, nossos sistemas conceituais por decreto" ${ }^{, 72}$.

De todo modo, há tentativas diversas na argumentação política, entre as quais a metáfora se destaca. De acordo com Charteris-Black (2011), no campo político, tende-se a utilizar a metáfora para se criar representações negativas de estados ou de agentes, a fim de apresentá-los como uma problemática, ou seja, um impedimento para o alcance do ideal social (efeito de futuro)

É, pois, incontestável que discurso e metáfora proporcionam ao ser político a possibilidade de construir situações sociais futuras, as quais, por vezes, caracterizam-se por serem idealizadas, tal como ocorre quando o orador procede de maneira a prometer uma sociedade ideal, na qual o valor de igualdade é utilizado.

\subsubsection{Valores do ideal social nos processos referencial-metafóricos}

Utilizar-se do valor de igualdade consiste de um tipo de estratégia selecionada de modo recorrente nos discursos políticos, conforme afirma Charaudeau (2006, p.78-79):

[...] não é de admirar que ele procure construir para si a imagem de um antecessor benfeitor, capaz de unir a condição humana da realidade social a um invisível ideal social, pois ele deve retribuir ao povo esse porquê que o fez conferir-lhe um mandato, o benefício de uma 'felicidade de ser". ${ }^{73}$

Se pensarmos que a sociedade ideal proposta pelo político pauta-se em valores e em crenças aceitos pela maioria de um auditório, a justiça social insere-se como fator essencial dessa idealização, que pode ser reforçada por meio de (re)categorizações diversas, metafóricas ou não. Perelman e Olbrechts-Tyteca (2002 [1958]) afirmam que a regra da justiça implica um valor argumentativo, segundo o qual pessoas de uma mesma categoria

\footnotetext{
${ }^{72}$ Tradução livre: We cannot freely change our conceptual systems by fiat.

${ }^{73}$ Grifo do autor.
} 
devem ser tratadas da mesma maneira. Este tipo de argumentação consiste de mais um modo de o orador criar efeito de coerência e de racionalidade em relação às suas ações, já que o discurso é fundamentado por um valor socialmente aceito.

Ressaltamos que, se por um lado o apelo à regra da justiça consiste de um valor aceito de maneira inquestionável, por outro, um embate pode ocorrer caso a imagem construída de igualdade seja questionada; isso ocorre, principalmente, na maneira como o político categoriza certos objetos de discurso.

Significa dizer que indivíduos podem ser construídos a partir de uma mesma categorização, por exemplo, os seres humanos, as crianças etc., o que efetiva a utilização do valor da justiça. Ao mesmo tempo, o conceito de igualdade pode ser desconstruído e a argumentação fragilizada, caso outro locutor queira negar a tese apresentada anteriormente e, assim, categorizar os mesmos objetos de discurso de modo distinto.

A fim de ilustrarmos tal afirmação, tomamos como exemplo algumas formulações linguísticas apresentadas nos pronunciamentos de Lula na Organização das Nações Unidas. Em trabalho anterior (Palumbo, 2010), examinamos que os discursos do ex-presidente brasileiro privilegiaram categorizações, pelas quais o conceito de desigualdade foi posto em evidência:

(10) ONU, 2004

Os silenciados pela desigualdade, a fome e a desesperança.

O olhar torturado dos que hoje estão do lado de fora da vida. São olhos que vigiam em nós o futuro da esperança.

ONU, 2005

Inocentes e indefesos.

1 bilhão de pessoas foram oprimidas pela fome.

Em (10) e (11), as seleções lexicais são indicativas de uma crítica do orador àqueles cujas condutas não estão de acordo com os direitos humanos. Tem-se que, ao categorizar, procede-se a dividir, isto é, a evidenciar, por classificação, a diferença de tratamento dada a alguns seres humanos. O que de fato ocorre é que Lula recorre a valores legitimados por este órgão internacional - ONU - no qual existem bases axiológicas que formam a imagem do grupo e, consequentemente, direciona certas expectativas, em termos de posturas, relacionadas a seus membros. 
Nesta acepção, a tese de haver necessidade de alterar um quadro mundial de desigualdade, assim como evidenciamos (Palumbo, 2010), fundamenta-se nas declarações dos direitos humanos, afirmações entre as quais, julgamos significativo destacar os artigos 1 , 2 e 25:

1. Todo os seres humanos nascem livres e iguais em dignidade e direitos. São dotados de razão e consciência e devem agir em relação uns aos outros com espírito de fraternidade.

2. Todo ser humano tem capacidade para gozar os direitos e as liberdades estabelecidos nesta Declaração, sem distinção de qualquer espécie, seja de raça, cor, sexo, idioma, religião, opinião política ou de outra natureza, origem nacional ou social, riqueza, nascimento, ou qualquer outra condição [...]

25. Todo ser humano tem direito a um padrão de vida capaz de assegurarlhe, e a sua família, saúde e bem-estar, inclusive alimentação, vestuário, habitação [...]

No âmbito internacional da política, entendemos que a carta das Nações Unidas consiste de uma diretriz significativa do que deve ser feito por parte de líderes estadistas, cujos países são membros permanentes. Neste viés, se o procedimento discursivo favorecer a ideia de justiça, em situações nas quais se prezam os valores dos direitos humanos, há de se reconhecer força pragmática dada à tese apresentada.

É o que ocorre nas seleções (10) e (11), e a metáfora serve para evidenciar sensações físicas de dor e de fome, bem como para privilegiar algumas informações em vez de outras, como é o caso das formulações referenciais que se iniciam por "Os silenciados" e por "O olhar torturado" (exemplo 10), nas quais o que vêm primeiro correspondem às expressões categorizadoras do objeto de discurso em questão, dando a entender o não cumprimento dos direitos humanos.

Seguindo nessa direção, é possível observar que, enquanto a igualdade é construída por meio da categorização "todo ser humano" na carta da ONU, no discurso de Lula, ela é desconstruída, principalmente, pela metáfora do contêiner, organizadora de um mundo desigual, a partir do momento que uma parte é excluída de uma categoria: "O olhar torturado dos que hoje estão do lado de fora da vida. São olhos que vigiam em nós o futuro da esperança" (exemplo 10). 
Ainda, observamos que apresentar fome, desigualdade e desesperança como agentesvilões - "Os silenciados pela desigualdade, a fome e a desesperança", "1 bilhão de pessoas foram oprimidas pela fome" (exemplos 10 e 11) - consiste de categorizar para acusar indiretamente, por pressuposto. Além do mais, dá-se, no processo referencial, a ideia da necessidade de mudança, quando se desconstrói a imagem de igualdade e, consecutivamente, de moralidade. Em vez de expor o aspecto negativo do auditório, preferiu-se orientar argumentativamente a partir da evidência do errado em termos de valores do grupo.

Temos, pois, possibilidade de criar, na interação, um jogo de negociação de sentidos metafóricos dos referentes textuais que irão interagir com outras estratégias argumentativas, como a da regra da justiça, conforme os propósitos argumentativos de cada orador e a situação interativa instaurada. Para Perelman e Olbrecths-Tyteca (2002 [1958], p.455), que entendem metáfora como analogia: "Todas essas analogias, presentes simultaneamente no espírito, se fecundam e se influenciam mutuamente, sugerem desenvolvimentos variados, entre os quais apenas o contexto permitiria uma escolha, raramente desprovida de toda a ambiguidade e de toda a indeterminação".

Pode-se dizer que, ao serem ativadas as correspondências entre esses domínios, algumas inferências, correspondentes a algumas representações mentais, são também ativadas, de modo a fornecer condições para que objetos de discursos sejam vistos de modo associativo, promovendo categorizações que possibilitam relacionar experiências corporais singulares a questões abstratas de ordem política, favorecendo um determinado encaminhamento de sentido e, assim, promovendo uma orientação argumentativa. Portanto, nota-se que a metáfora tem o papel de organizar e de categorizar objetos de discurso e de pensamento na rede referencial, ao mesmo tempo, em que é reforçada por esta. Mais do que isto, é pela metáfora que se torna possível relacionar diversas categorias no discurso, dando margem a novos sentidos e olhares.

Assim, pela discussão apresentada, é importante considerar o discurso político, e todos os fatores que nele estão imbricados, como ação intersubjetiva, que visa, principalmente, à persuasão e ao convencimento. São atitudes que dizem respeito ao uso de saberes específicos, ou mesmo, pode-se afirmar que correspondem a saberes em ação - como a seleção de metáforas conceptuais e suas ocorrências linguísticas - aplicados em condições específicas da vida política para fins definidos e planejados. Portanto, os políticos, durante ou anteriormente à atividade discursiva em que estão engajados, mobilizam estrategicamente diversos conhecimentos de ordem linguístico-cognitiva, a fim de apresentarem um dizer interpretável, 
orientador, provocador de reações e, consecutivamente, modificador de circunstâncias políticas e sociais.

De todo modo, sabemos que é preciso tentar garantir, no mínimo, a compreensão do que é proposto pelo orador. Por tal razão, a metáfora pode colaborar para que o auditório visualize o efeito (futuro) da proposta, que o ajuda a entender uma determinada ação, ou viceversa, conforme o que é evidenciado no discurso.

\subsection{Seleção de metáforas perante auditórios específicos e orientação argumentativa}

Sobre a questão da metáfora conceptual, no discurso, trazer à tona um conjunto de crenças e de valores compartilhado entre os participantes de um dado encontro e fortalecer a proposta argumentativa do falante e de seu grupo, é imprescindível considerar a necessidade de adaptação ao auditório, para que a estratégia seja capaz de atender as propostas de sentido do orador. A metáfora deve favorecer e reforçar os valores dos interlocutores, a fim de que se tenha aproximação entre as partes e possibilidade de negociação, de acordos. Se isto é indispensável no que diz respeito à argumentação de modo geral, tratar de questões voltadas para a política externa - que envolvem a busca de alianças políticas, a promoção da imagem de um Estado, ou seja, de sua legitimidade a fim de alcançar/manter espaço no comércio internacional etc.- equivale a reconhecer a diversidade de público para quem o discurso proferido por um chefe de Estado é direcionado. Culturas, idiomas, regimes políticos diversos fazem parte da configuração desses encontros e devem ser levados em conta no planejamento do discurso.

Isso se deve ao fato de que uma condição prévia de qualquer argumentação consiste na necessidade de o locutor considerar as características sociais, psicológicas, culturais e históricas de seus interlocutores para, assim, criar uma imagem de seu auditório e adaptar o discurso a ela (Perelman e Olbrechts-Tyteca, [1958], 2002). A partir disto, colocar-se-á em prática uma série de processos argumentativos diferenciados na tentativa de reforçar ou de modificar, se for necessário, o sistema de conhecimentos e de crenças daqueles a quem se deseja convencer e/ou persuadir. Isto se pode dar, como indicamos, por meio da seleção de metáforas associada a outras estratégias argumentativas. Neste viés, se o mapeamento favorecer um alinhamento entre a tese defendida e os valores assumidos pelo auditório, 
tornar-se-á viável ao discurso ser aceito. Isto porque há acordos próprios de alguns auditórios, de tal modo que aquilo que é válido para um grupo pode gerar estranheza em outro.

Para alguns retóricos, como Aristóteles e Quintiliano, diferentes contextos situacionais requerem estratégias argumentativas específicas. Observa-se que influenciar decisões políticas implica selecionar algumas técnicas discursivas que não seriam, necessariamente, escolhidas em outras circunstâncias da vida, uma vez que, levando em conta o pressuposto da retórica grega, efeitos de verdade são motivados conforme o tempo, o lugar e a situação instaurados entre os participantes.

Charteris-Black (2011) parte desse viés e afirma ser essencial os políticos identificarem o conjunto de valores de seu auditório para alcançarem legitimidade política, isto é, a base da ação, no campo político, consiste de proceder discursivamente a partir do se acredita ser bom ou ruim, certo ou errado, perante os olhos de públicos diversos. Nesta direção, o discurso pode ser bem recebido, caso orientar uma representação mental motivada moral e eticamente. É o que ocorre, ainda conforme esse estudioso, quando um líder político seleciona o conceito de família nacional como estratégia argumentativa, pois é um modo de simbolizar a segurança e a proteção supostamente promovidas pelo governo de um Estado a partir de um sistema de valores que é aceito pela maioria e que, assim, favorece a imagem pública do político como alguém com boas intenções.

Lakoff (2002), por sua vez, assinala que a seleção de metáforas correspondentes ao frame família e a seu sistema de valores consiste de um procedimento central do discurso político. Para esse estudioso, a construção de uma nação em termos de família possibilita a ligação da ideia de posicionamentos políticos diferentes, como o conservador e o liberal, às moralidades de base familiar, em que há o pai rigoroso e o educador; sobre isto, assinalamos a importância de se observar que o olhar sobre os membros de uma família pode diferir conforme a cultura de um auditório, ou mesmo, de uma parte dele, pois este pode ser composto por grupos diversificados. Isto significa dizer que vale considerar a diversidade de opiniões existentes no conjunto daqueles que se pretende atingir e tentar encontrar, por exemplo, um valor que os una e os torne dispostos a agir de certa maneira.

Desse modo, caso o orador considere as especificidades do auditório, a seleção de metáforas conceptuais pode fornecer condições ao discurso para que este se apresente com valor de verdade, visto como essencial para a argumentação. Sobre este último ponto, já nos estudos da retórica aristotélica, retomados pela Nova Retórica de Perelman e OlbrechtsTyteca (2002 [1958]), considerava-se a necessidade de se levar em conta as crenças, os 
valores daqueles que se pretende convencer e/ou persuadir, para que as premissas apresentadas nos discursos pudessem ser vistas como verossímeis (prováveis ou controversas) e, consecutivamente, revistas, negociadas e aceitas ou não pelo auditório ou parte dele.

Considera-se tal afirmação pelo fato de aqueles a quem a argumentação se destina não serem vistos como ouvintes passivos, mas sim como capazes de reagir às teses apresentadas de modo a avaliá-las, a contestá-las ou a aceitá-las de imediato ou não. Nos espaços nacionais ou globalizados da vida política, é usual observarmos tal dinâmica nos discursos de políticos, quer seja por eles terem de enunciar respostas/réplicas, quer pela necessidade de interagirem, ao mesmo tempo, com adversários, aliados, eleitores, profissionais da mídia, entre outros, a fim de conduzir uma interação e garantir determinada coprodução de sentido em meio de reações cognitivo-discursivas diversas e não esperadas por vezes ${ }^{74}$.

Em função dessa adequação a um auditório, Aquino (1997, p.161) afirma que:

\begin{abstract}
A argumentação dirigida a um auditório universal procura convencer os interlocutores da evidência das razões apresentadas e de sua independência de contingências locais ou históricas (As noções de real, de verdadeiro, de válido e de evidência mudam, não são fixas). A argumentação apresentada a um auditório particular procura persuadir o ouvinte a realizar uma ação imediata ou futura, desenrolando-se essencialmente no plano prático.
\end{abstract}

Ao se tratar de auditórios heterogêneos, o orador poderá levar em conta os marcos sociais dos participantes do encontro e examinar se eles assumem, na situação interacional, um mesmo grupo social ou múltiplos e se, nestes casos, apresentam posicionamentos opostos. De fato, é possível dividir o auditório pelas funções sociais - políticos, empresários, jornalistas etc. - e considerar os valores que cada qual assume nesses papéis. Nestas situações, os argumentos, devem, pois, ser variados para que se alcance adesão. Além do mais, mesmo quando se trata de um grupo delineado pela mesma função social, entende-se que cada

\footnotetext{
${ }^{74}$ Ao assinalarmos que o auditório nem sempre se configura por um grupo homogêneo e que se caracteriza por haver ações e reações diversas dos participantes, partimos da classificação feita por Perelmam e Olbrechs-Tyteca (2002 [1958]). Para eles, o auditório pode ser considerado particular - grupos específicos que assumem determinadas ideologias e específicas funções sociais, o que permite atribuir a eles lugares comuns - e/ou universal - o qual se delineia pela argumentação provável de ser aceita pela maioria, como a seleção de verdades filosóficas, de dados da ciência.
} 
integrante possui particularidades, locais e históricas, e faz parte de múltiplos grupos em outras circunstâncias da vida.

De todo modo, é preciso garantir a compreensão e, em certa medida, a aceitação ao auditório, e o desempenho positivo/negativo daquele que diz muito se deve ao "modelo de evento" (VAN DIJK, 2007, 2009, 2010) a partir do qual ele elabora seu discurso. Com efeito, ao mesmo tempo em que o orador ativa um conhecimento específico a respeito da situação na qual ele está (quem são os participantes naquele instante, os objetivos da interação, a data, o local etc.), seu procedimento discursivo também está relacionado à ativação de conhecimentos mais gerais, genéricos - como: qual a característica do papel social que ele assume, isto é, o que é o político, um chefe de Estado ou de governo, como se configura de modo geral, por exemplo, encontros bilaterais, entre outros - e ao gerenciamento de todos eles, em um processo em que se articulam informações velhas (gerais) e novas (locais).

Em relação aos encontros, cujo auditório caracteriza-se por ser heterogêneo - como os dos pronunciamentos examinados neste trabalho - ainda salientamos que o orador deve considerar que, para o público compreender a metáfora e, a partir dela, fazer inferências, ele precisa conhecer o modelo mental, estruturado metaforicamente, que foi apresentado. Isto quer dizer que a metáfora atua argumentativamente por meio de um conhecimento mais geral e comum, o domínio-fonte, a partir do qual pode gerar um novo (localmente construído). Nesta direção, tem-se que a aceitação da tese pode ser alcançada se os valores reconhecidos nesses modelos estejam alinhados àqueles que o orador quis propor.

Em relação ao auditório particular, (Perelman e Olbrechts-Tyteca, 2002 [1958], p. 23) afirmam que:

Cada meio poderia ser caracterizado por suas opiniões dominantes, por suas convicções indiscutidas, pelas premissas que aceita sem hesitar; tais concepções fazem parte da sua cultura e todo orador que quer persuadir um auditório particular tem de se adaptar a ele. Por isso a cultura própria de cada auditório transparece através dos discursos que lhe são destinados, de tal maneira que é, em larga medida, desses próprios discursos que nos julgamos autorizados a tirar alguma informação a respeito das civilizações passadas.

Logo, os valores, mencionados por diversas vezes neste trabalho, consistem em objetos de acordo de auditórios particulares, pois, quando comuns, possibilitam “a comunhão 
sobre modos particulares de agir" (op. cit., p. 84). Ainda, recorre-se a esses valores por eles estarem vinculados a maneiras específicas de entender o mundo e, assim, de fazer julgamentos e escolhas. E mesmo que haja controvérsias em relação a algum valor e, por conta disto, ele seja refutado, desqualificado, não é possível negar, de modo geral, todos eles. Alguns deles, portanto, inseridos em dada situação e associado a um conjunto de crenças, podem até mesmo alcançar estatuto de fato.

Há, sem dúvida, valores pertinentes à maioria, isto é, que são suscetíveis a serem aceitos por boa parte das pessoas, como o bem, o verdadeiro, o belo etc., assim como afirmam os autores da Nova Retórica; entretanto, estes autores consideram que, na medida em que esses valores são relacionados a certos tópicos, somente agirão em auditórios particulares, pois a eles se ajustam. Neste viés, se a beleza é valor que tende a ser universal, o conceito a ela atribuído dá-se de modo particular, tal como também ocorre com a justiça, a verdade, entre outros. É, portanto, na atividade discursiva que o orador encaminhará um olhar sobre o objeto de discurso de modo que valores e noções comuns auxiliem nos efeitos pretendidos.

Ainda de acordo com Perelman e Olbrechts-Tyteca (2002 [1958]), existem valores abstratos e concretos que são estreitamente relacionados, quando o tratamos a partir de um viés argumentativo. Tal distinção é evidenciada pelos autores por meio de alguns conceitos relacionados à sociedade e a seus grupos. No primeiro caso, há valores não tangíveis, como aqueles já indicados, a justiça, a verdade, e mais outros, a liberdade, a igualdade, a caridade etc. Quanto ao segundo, este se relaciona a entidades concretas, a um grupo, a um objeto, tais como a fidelidade, a lealdade, a solidariedade, entre outros. Examinemos o que os autores afirmam a respeito disto (op. cit., p. 87):

Enquanto a moral ocidental, na medida em que se inspira em concepções greco-romanas, atribui importância sobretudo à observância de regras válidas para todos em todas as circunstâncias, existem comportamentos e atitudes que não podem ser concebidos senão em comparação com valores concretos. As noções de envolvimento, de fidelidade, de lealdade, de solidariedade, de disciplina são dessa espécie. Da mesma forma que os cinco deveres de obrigação universal de Confúcio, entre governantes e governados, entre pai e filho, entre marido e mulher, entre irmão mais velho e irmão mais novo, entre amigos, são a expressão da importância dada às relações pessoais entre seres que constituem valores concretos uns aos outros. 
Ainda, conforme a situação interacional, ora serão apresentados valores abstratos ora concretos, ou mesmo, ambos ao mesmo tempo, já que um fundamenta o outro. Além do mais, podemos entender que, de um valor concreto, chegamos a um abstrato e, assim, compreendemos este por meio daquele.

A partir desses conceitos, vemos, pois, uma das maneiras como algumas metáforas podem agir na argumentação apresentada a auditórios com características peculiares, como o da política externa, em termos de sua composição. A seleção de certos modelos cognitivos estruturados, tal como família e guerra, age, sobretudo, de modo a fazer que os interlocutores ativem valores concretos - atribuídos por parte de alguns grupos de modo convencional aos agentes categorizados nesses domínios - e cheguem a valores abstratos, como os de paz, de união, de justiça entre outros, os quais orientam avaliações específicas de conduta e são suscetíveis à aprovação da maioria.

Interessa-nos também assinalar que os valores abstratos, supostamente, são significativos quando empregados em situações nas quais o orador almeja algum tipo de mudança. Isto tem como pressuposto também os estudos de Perelman e Olbrechts-Tyteca (2002 [1958]), para quem esses tipos de valores podem fundamentar ideias revolucionárias, uma vez que não são direcionados, explicitamente, a determinadas pessoas ou a objetos concretos e consistem em um modo de apresentar incompatibilidades.

Ainda, julgamos significativo salientar que, por ser a ação de agir sobre o outro a fim de modificá-lo e/ou fazê-lo tomar certas decisões e atitudes um processo em que se articulam elementos internos e externos da linguagem e da cognição, nem sempre o indivíduo interpelado pelo nome consiste na única pessoa que se quer convencer e/ou persuadir, como já postulado por Perelman e Olbrechts-Tyteca (2002 [1958]). Assim, o discurso pode ser elaborado também para quem participa indiretamente de uma interação, como é o caso de um debate político televisivo, em que os participantes visam a influenciar a opinião pública do país. Neste caso, tal propósito os leva a proceder de modo a atingir, principalmente, a terceira parte (a audiência), embora pareça, por vezes, que os políticos estejam interagindo apenas entre si.

Podemos afirmar que ocorre da mesma maneira com os discursos proferidos pelo expresidente Luis Inácio Lula da Silva, em encontros na ONU, no MERCOSUL, no Fórum Econômico Mundial, entre outros. Sabemos que, pela sua característica pública, esses enunciados foram disponibilizados em sites do governo federal brasileiro e, muitos deles, em jornais impressos e televisionados de ampla circulação, como Folha de São Paulo, Estado de 
São Paulo, Globo News etc. Este procedimento possibilita uma interação, mesmo que a distância, com o público brasileiro, o qual pode ser considerado também auditório desses pronunciamentos.

Pelo que se expôs sobre a relação entre argumentador e auditório, torna-se importante salientar que o orador ora pode, em seu discurso, dirigir-se a um auditório universal, selecionando recursos argumentativos pertinentes à maioria, ora a um particular, apresentando estratégias direcionadas a determinados grupos; ou mesmo atingir os dois de uma vez. $\mathrm{O}$ tratamento dado ao discurso é traçado de acordo com a imagem presumida de um auditório o qual pode apresentar, ao mesmo tempo, características heterogêneas (universais) e específicas. Assim, se a metáfora for utilizada de modo estratégico, tudo indica que a rede metafórica e referencial do discurso será alinhada aos possíveis endereçamentos feitos pelo locutor durante o encontro, ou seja, poderá servir para auditórios específicos em certos momentos e para universais em outros.

Ressaltamos, ainda, segundo Aquino (1997), que tanto o argumentador quanto o auditório podem ser modificados durante a interação. Em outras palavras, conforme a argumentação apresentada, os interlocutores podem despertar lembranças e emoções de tal modo que eles não serão os mesmos no final do encontro. Ao argumentador, pois, cabe perceber essas transformações e, se necessário, mudar as estratégias argumentativas empregadas, quando o momento enunciativo oferecer tal possibilidade. Em pronunciamentos, mesmo quando o auditório não esteja interagindo verbalmente com o orador, pode-se dizer que seus contextos cognitivos estão. Tal processo pode ser observado, de certo modo, por meio de pistas extralinguísticas, como olhares, gestos etc.

Vale-nos também relacionar esta imagem presumida do auditório, novamente, à questão dos modelos cognitivos de eventos de Van Dijk (2007, 2009, 2010) discutidos nos capítulos 1 e 2 deste trabalho. Como expusemos, o político - com a ajuda daqueles que participam da elaboração do discurso - cria imagens a respeito de si, do outro e de determinados encontros sociais ou, em específico, de certas situações da vida política e faz escolhas situadas, pelas quais se torna possível agir sobre o auditório, na tentativa de se adequar a ele e, assim, de orientar ações e pensamentos. Nestes casos, pode-se dizer que a imagem presumida do auditório é também construída pela assessoria do político, isto é, tratase de uma construção dinâmica e coletiva de objetos de pensamento e de discurso (auditórios, lugares de produção etc.), em que o propósito é comum: alcançar legitimidade para o orador, que assume o dizer. 
Enfim, nessas situações interativas da vida política, em que o discurso alcança milhares de pessoas, conhecer as metáforas que circulam em uma nação ou em um grupo específico, como os principais valores imbricados nelas, torna-se essencial aos propósitos argumentativos de um político, ou de seu partido, pois a seleção de metáforas pode propiciar um terreno comum no âmbito cultural (Kövecses, 2005; Lakoff e Johnson, 1980, 2003) e, também, na perspectiva cognitiva (relações mentais), permite agir na orientação de novos olhares, novos conceitos, a partir de concepções já estabelecidas. E é neste sentido - tentativa de direcionar conclusões - que a seleção específica de termos metafóricos pode estar a serviço da argumentação (Koch, 1996; Perelman e Olbrechts-Tyteca, 2002 [1958]).

Embora saibamos que o discurso presidencial proferido seja planejado e, por conta disto, as características do auditório recebam atenção, devemos levar em conta, no que se refere à argumentação política em uma dimensão global, que a metáfora e o discurso podem surtir efeitos diversos, conforme a interação instaurada entre estes e o auditório, que se configura, como exposto, pela diversidade de experiências coletivas e individuais, por elementos culturais, pela diferença de idiomas etc.

\subsection{Metáforas conceptuais, expressões metafóricas e construção de sentido em discursos situados}

Em situações específicas da vida, se é no e pelo discurso que a metáfora conceptual atua a partir da disposição e da organização de certos recursos linguísticos, interessa-nos ainda considerar que as formulações, pelas quais sentidos metafóricos podem ser encaminhados para fins persuasivos, também são polissêmicas; entretanto, é possível encontrar, na organização do discurso, no cotexto e na situação de interação, pistas linguísticas, que delimitam ou direcionam os efeitos de sentido desse uso metafórico da língua. Como assinala Marcuschi (2007), o sentido não está na língua em si, nas palavras ou nas formulações isoladas, mas sim em uma rede lexical situada em um sistema social e interativo, isto é, os efeitos não são efetivados isoladamente.

Mais uma vez, podemos afirmar que a metáfora no discurso recebe ajustes da configuração que a ele dá corpo; seu uso, pois, será sempre atualizado, e os mapeamentos apresentados delinear-se-ão na interação com outras informações presentes, de modo a fazer que, até mesmo, as metáforas consideradas de uso recorrente em certas culturas ou em um determinado campo de atuação humana e seus respectivos e variados registros linguísticos - 
tais como PROCESSOS POLÍTICOS SÃO CONSTRUÇÕES e ESTADO É ORGANISMO, entre outras observadas como recorrentes por Chilton (1996) e de Chilton e Schãffner (2002) na esfera política internacional - podem ganhar, a qualquer momento, outros encaminhamentos de sentido. Nesta acepção, não estamos nos referindo aos mapeamentos novos, criativos, mas sim ao modo como as associações de domínios, em geral, são postas em discursos situados e dialogam com informações internas e externas a eles. Basta, assim, inserir a metáfora em uma situação inusitada que tal configuração permitirá a apresentação de mapeamentos singulares.

Nessa direção, Chilton (1996) e de Chilton e Schãffner (2002) examinaram o uso de metáforas nas relações internacionais e identificaram a existência de quatro maneiras recorrentes de seleção metafórica: a primeira delas relaciona-se à metáfora de contêiner, ou seja, regiões geográficas, geralmente, são descritas como contêineres de pessoas, procedimento que ajuda a formar, por vezes, o conceito de nação; a segunda refere-se à metáfora do caminho, em que estão implicados pontos de partida e de chegada, movimentos e direções, estratégias políticas; já a terceira metáfora corresponde à da força, a questões voltadas a resistências e a pressões de ordem política (macro), a partir da qual o político pode construir sua imagem de poder fazer; a última metáfora, denominada link, é utilizada para construir relacionamentos entre grupos, nações etc.

Ressaltamos, ainda, que, nos estudos de Perelman e Olbrechts-Tyteca (2002 [1958]), existem observações acerca da relação sentido metafórico, formulações linguísticas e especificidades circunstanciais. Embora saibamos que esses autores não se tenham detido ao exame de questões cognitivas, consideramos que seus estudos partem de uma visão multidisciplinar por tratarem a argumentação como ação discursiva e social, na qual o auditório consiste de uma imagem construída do orador a partir também de sua percepção, e os efeitos argumentativos são produtos de relações entre indivíduos, cujas características psicológicas e culturais entram no jogo.

Por esse motivo, parece-nos pertinente indicar a afirmação desses autores a respeito da possibilidade de expressões metafóricas de uso comum receberem direcionamentos novos a partir de sua inserção em situações inusitadas, de sua interação com outras estratégias ou com o uso de uma nova analogia. Para Perelman e Olbrechts-Tyteca (2002 [1958], p.460), essas seleções linguísticas metafóricas, "adormecidas", cumprem força argumentativa por elas já estarem enraizadas em tradições culturais e discursivas de determinados auditórios. O 
seu reviver, pois, pode ser considerado estratégico, por elas se ajustarem ao discurso, ao auditório e ao momento enunciativo:

Parece-nos, quanto a nós, que seu valor na argumentação é eminente sobretudo por causa da grande força persuasiva que possuem essas metáforas adormecidas quando, com o apoio de uma técnica e outra, elas são novamente postas em ação. Essa força resulta do fato de elas tirarem seus efeitos de um material analógico facilmente aceito, pois não é só conhecido, mas também integrado, pela linguagem, na tradição cultural. (Perelman e Olbrechts-Tyteca, op. cit.)

Por examinarmos, neste trabalho, pronunciamentos feitos pelo ex-presidente da República do Brasil, em encontros caracterizados pela variedade de culturas, unidas em um só auditório, cabe-nos também ressaltar que essas formulações metafóricas já adormecidas, ou mesmo as novas, podem diferir conforme o idioma utilizado e os tipos de conhecimento que o auditório possui. Isto quer dizer que, se uma expressão linguística - a partir da qual se ativa um modelo cognitivo - é constantemente utilizada em uma determinada cultura, mesmo que se trate de um mesmo idioma, em outro contexto cultural, ela pode ser percebida como algo inusitado, ou mesmo, apresentar-se com um olhar inovador.

A esse respeito, Perelman e Olbrechts-Tyteca (2002 [1958], p. 462) observam a relação entre o uso de formulações metafóricas, a especificidade do auditório e o idioma utilizado, focando na função argumentativa dessas metáforas de uso comum, denominadas por eles "expressões de uso metafórico":

Como as expressões de uso metafórico não são as mesmas nas diversas línguas e o grau de entorpecimento de uma mesma metáfora pode ser muito diferente, a tradução sempre modificará algo a esse respeito. O mais das vezes ele terá como consequência fazer as metáforas reviverem. Há mais, um texto estrangeiro, lido em seu idioma original, costuma proporcionar, se este não for plenamente familiar ao leitor, uma impressão de vida e de movimento, um prazer particular, proveniente do fato de se apreender como metáfora viva o que talvez só fosse metáfora adormecida.

Ainda, para Perelman e Olbrechts-Tyteca (2002 [1958]), a argumentação age também a partir de uma comunhão cultural. Trazer o que é comum em dada cultura, na tradição, em 
um passado comum consiste de uma prática indispensável, por vezes, em razão de, por ela, se buscar negociação de sentido sobre aquilo que é posto em evidência. Nesta direção, temos que o discurso presidencial voltado para os políticos ou outros indivíduos do exterior emerge de contextos situacionais, nos quais a interação se efetiva entre culturas diversas, vale-se de empréstimos de associações específicas, culturalmente constituídas, para que se convalide o que se tem como proposta enunciativa.

Selecionar informações do cotidiano do auditório, ou de sua história, pode ser um modo de transformar um conhecimento específico e cultural em um dado novo e avaliativo, caso ele seja associado a questões mais complexas ou a contextos situacionais e culturais mais distantes das experiências de um público. É neste sentido que entendemos ocorrer a construção discursiva de processos no campo político internacional, sobretudo, pelo fato de considerarmos que uma dada informação pode servir como dispositivo de uma série de associações, no desenvolvimento do discurso, que tenderá a remeter a um universo cognitivo de determinado experiência humana de modo enviesado.

Ao nos debruçarmos sobre a metáfora selecionada nas práticas discursivas perante indivíduos com características diversificadas em termos de fatores culturais e sociais, ainda indicamos a afirmação de Kovecses (2005), para quem o entendimento de experiências empíricas pode ou não ser compartilhado entre pessoas de culturas distintas, como mencionamos no primeiro capítulo. $\mathrm{O}$ autor afirma que, quando se observa a metáfora em diversas línguas, pode-se identificar que há inúmeras não universais, as quais são tão numerosas, ou mais, quanto as universais. Isto é, notam-se de modo frequente mapeamentos singulares em alguns contextos culturais, ou mesmo, em determinados dialetos.

A cultura consiste de um fator essencial nas práticas políticas internacionais, principalmente, quando se considera que as construções discursivas fazem parte de processos interacionais e de estruturas cognitivas; assim, o termo não pode ser separado dos elementos cognitivos inseridos em uma sociedade. Tal acepção torna-se significativa para os propósitos deste trabalho, em razão de os políticos em interação inserirem-se em situações de diversidades culturais. Se por um lado, há interesses que os aproximam, por outro, diferenças culturais dão entornos diferenciados a esses encontros e a produção discursiva.

Nesse viés, o campo de nosso estudo recai sobre a interação caracterizada pelo diálogo entre múltiplas culturas, em que o discurso, a ideologia, os modelos de contexto ligam-se a elementos culturais. Parece-nos coerente dizer que corresponde a culturas em interação, que ganha espaço significativo na configuração de práticas discursivas entre povos que se 
modelam às tendências da globalização, fazendo com o mundo por si só se torne global e, assim também, a política e os discursos que a ele dão sentidos.

De acordo com Kovecses (2002), é possível definir dois tipos de variação cultural: a transcultural (intercultural) e a intracultural (variações individuais). Em relação à primeira, que nos interessa, sobretudo, em razão dos participantes do cenário político internacional, temos que a atividade de dar sentido ao mundo parte de um processo em que se articulam as experiências sociais dos indivíduos e o modo que estes as entendem e as conceptualizam. São organizações dos conhecimentos que criam coerência às inter-relações humanas, de maneira que a língua posta em discurso em si não consiste no único fator que possibilita a produção do sentido sobre aquilo que as pessoas se debruçam. Isto porque são inerentes às práticas discursivas maneiras específicas de ver e de entender uma sociedade, fazendo que seleções lexicais encaminhem efeitos diversos, por estarem ligadas também a valores culturais.

Para Kovecses (2005), por um lado, não necessariamente experiências corpóreas universais resultam em metáforas universais, pois podem também ser utilizadas na construção de metáforas novas. Além disto, o autor sugere que as primárias são suscetíveis a se universalizarem, ou seja, podem ou não estarem presentes em diversos contextos culturais, como também é possível ocorrer com as complexas.

Tal afirmação pressupõe, ainda conforme Kovecses (2005), a ideia de que algumas metáforas são baseadas em processos cognitivos de vários tipos e implicam saberes culturais específicos. Isso se deve ao fato de o autor observar a metáfora como fenômeno, ao mesmo tempo, linguístico, conceptual, sociocultural, neural e corpóreo. Neste viés, as metáforas produzem modelos culturais, representações mentais do mundo, que operam no pensamento.

Esse estudioso segue afirmando que a metáfora pode variar em uma mesma cultura. Neste viés, a dimensão social e regional, a ética de um grupo, o estilo, etc. também influenciam na utilização de metáforas. Em relação aos fatores sociais - a idade, o sexo, entre outros - estes podem refletir na maneira como os indivíduos conceptualizam determinados objetos de discurso (homem referindo-se à mulher; mulher referindo-se ao homem). Como também, grupos tendem a compartilhar maneiras metafóricas de se referir a alguns eventos e agentes.

Novamente, há menção à relação intrínseca entre experiência corpórea, mente, mundo, práxis e discurso. Isto porque as metáforas, até as primárias - supostamente/potencialmente universais - não estão afastadas dos indivíduos, imersos em culturas distintas. Retomemos o 
pressuposto de Kövecses (2005), discutido à página 169, para quem existem dois tipos de variações que influenciam na constituição de metáforas: a intercultural (nações diferentes) e a intracultural (grupos diferentes). Isto indica, mais uma vez, que a construção metafórica de objetos de discurso está relacionada ao ambiente sociocultural e é dinâmica, como assim mencionamos no capítulo 1 deste trabalho.

Construir sentido de um objeto de discurso, logo, consiste de um processo complexo e extremamente necessário em termos argumentativos, principalmente, quando se trata do campo da política internacional, em que a negociação de sentido do que é posto em evidência no discurso cumpre papel diplomático e merece atenção por parte dos participantes do encontro e daqueles que planejam o discurso escrito; uma coletividade que precisa agir por meios discursivos e exercer poder.

Entendemos que a construção de sentido, metafórico ou não, e a força argumentativa advinda desse processo estão atrelados à dimensão discursiva. Nesta direção, o modo como o discurso é organizado e a presença de outras estratégias argumentativas, é que pode conduzir o outro a determinada conclusão. Assim como assinalam Perelman e Olbrechts-Tyteca (2002 [1958], p. 117), "a escolha dos auditórios e dos interlocutores, assim como a ordem na qual se apresentam as argumentações, exercem grande influência na vida pública".

Portanto, consideramos que a organização discursiva é que confere à fala/escrita certo teor argumentativo, no decurso da interação, orientando argumentativamente o auditório na inter-relação das informações postas. Neste viés, propomos que o momento em que a metáfora aparece no discurso pode indicar o porquê de seu emprego e promover efeitos específicos por meio, entre outras possibilidades, das redes referenciais.

\subsection{Sequência de ações no discurso, usos da metáfora conceptual e do léxico}

Pelo que expusemos, a argumentação pode ser entendida como uma prática socialinterativa caracterizada por ser um procedimento discursivo, que envolve intersubjetividade, seleções linguísticas, fatores pragmáticos - como a questão da adequação à situação de interação e aos interlocutores - e sociocognitivos - na medida em que as estratégias são reconhecidas e pelo fato de a modificação de um contexto cognitivo consistir em um propósito argumentativo.

Como discutimos também, as estratégias discursivo-argumentativas marcam-se linguisticamente no cotexto, dialogando entre si e com os dados contextuais (o cognitivo e o 
situacional). Isso permite dizer com Aquino (2005) que o discurso se constitui por diversas estratégias as quais interagem uma com as outras, estabelecendo-se, assim, um jogo estratégico de argumentos que pode alterar e ser alterado, conforme o encaminhamento dado à interação. Ainda segundo Aquino (2005, p. 109):

O jogo estratégico dos argumentos, constituído por formulações linguiísticas específicas, permitirá que se visualizem alterações no contexto que acaba por se modelar e remodelar, criando uma possibilidade de compreensão do significado que ganha corpo com o desenvolvimento do discurso, com o desenrolar da interação.

Desse modo, pode-se entender que a organização discursiva - o que se apresenta e quando apresenta - cumpre papel significativo na preparação e na orientação argumentativa de um auditório, ou seja, a sequência e o tipo de informação apresentados em um discurso podem alterar ou reforçar certa disposição por parte dos interlocutores de maneira que estes tenham condições de seguir os argumentos postos, principalmente, quando se trata do discurso escrito, que é planejado, e sua organização, logo, privilegiada. Por vezes, negocia-se, no percurso do discurso e da interação, a mudança de um contexto cognitivo, a fim de que uma proposta política possa ser validada pelo auditório.

A importância da organização discursiva já fora apresentada por Aristóteles, na Arte Retórica, quando ele discutira a respeito das partes da argumentação. Sobre isto, sabe-se que, na retórica clássica, foi demonstrado que a argumentação se efetiva a partir de dois fatores ligados à produção discursiva e a alguns elementos externos a ela: a estrutura ou a organização do discurso - em que a preocupação versa sobre a sequência das informações do discurso, associada às técnicas de memorização e de gestos, a partir da qual o orador governa o auditório a seguir um argumento - e o estilo (seleção lexical).

No primeiro caso, propôs-se a existência de uma sequência de ações nos discursos argumentativos, pelas quais o locutor age na tentativa de encaminhar o auditório a aceitar os argumentos organizados e apresentados a ele. Nessa composição, foram apresentadas cinco etapas: exórdio, narração, prova, refutação, conclusão e epílogo. Há, nessas etapas, a necessidade de obter certo poder sobre o auditório por meio da heuresis (ou inventio ${ }^{75}$ ), em que se procura determinados argumentos para persuadir o outro, e pela taxis (ou dispositio ${ }^{76}$ ),

\footnotetext{
${ }^{75}$ Inventio, em latim; heuresis, em grego.

${ }^{76}$ Dispositio, em latim; taxis, em grego,
} 
um plano de organização desses argumentos para que eles se tornem plausíveis e racionais. Para Charteris-Black (2011), boa parte dos discursos políticos da atualidade manteve tal organização.

Em relação à primeira parte da argumentação, o exórdio, este foi o que chamou mais atenção de vários estudiosos da Retórica, como Aristóteles, Cícero, Quintiliano. É no primeiro contato estabelecido entre orador e auditório que a argumentação cumpre papel importantíssimo, pois, nesse momento, deve-se despertar o interesse, chamar a atenção, criar efeitos de credibilidade, encantar o outro, já que se torna extremamente difícil conduzir o interlocutor à aceitação de uma tese, se ele estiver desatento ao que se fala ou desinteressado pelo que se enuncia. Nas palavras de Perelman e Olbrecths-Tyteca (2002 [1958], p.561): “ O orador tentará, em seu exórdio, dar a conhecer sua competência, sua imparcialidade, sua honestidade". Já quando o discurso, no primeiro momento, voltar-se a um auditório universal, os autores assinalam a tendência de se usar fatos, a fim de se alcançar efeitos de objetividade.

É preciso, no exórdio, sobretudo, observar as relações específicas criadas entre orador e auditório e proceder de modo a alcançar comunhão e confiança. Fazer alusão à amizade de dois povos ou a um fator cultural em comum, bem como trazer uma informação que o agrade de algum modo são procedimentos que promovem um efeito de afinidade em termos de valores, quando utilizados no primeiro momento da interação.

Nessa direção, dizem os autores da Nova Retórica que a formulação do exórdio sempre estará relacionada às circunstâncias do encontro, à relação estabelecida entre os participantes (adversários ou não), ao assunto tratado etc.; dependendo do momento enunciativo, logo, o orador pode criar dois exórdios, se assim for necessário e possível. Isto também quer dizer, por outro lado, que o auditório conhece as regras que justificam certos tipos de exórdio, podendo aceitá-los ou não; a argumentação, novamente, pressupõe préconhecimento dessas regras de conduta, que motivam os participantes a agirem e a reagirem de certo modo.

Posterior ou concomitantemente ao exórdio, o orador procede de maneira a apresentar sua tese, a ideia que pretende defender. Esta, por sua vez, consiste no fio condutor de sentido do que se enuncia e deve ser informada de tal modo que se consiga envolver o auditório, para que haja adesão à proposta. Por um lado, quando a tese é demonstrada de imediato, é possível já esclarecer o que será defendido, por outro, a tática consiste de enunciála durante o desenvolvimento do discurso, para que haja maior possibilidade de previsão das 
objeções ou de preparar e modificar os contextos cognitivos. Tudo dependerá das condições específicas de produção, as quais determinam, em parte, a organização do discurso.

Assim também ocorre com os argumentos organizados que orientam e dão força ao que se diz, conforme as etapas do discurso, nas quais são mobilizadas técnicas articuladas à razão e à emoção (Cf. p. 134-135). Neste viés, o papel da organização discursiva é, fundamentalmente, a orientação, isto é, o condicionamento do auditório e do autor que a elaborou, pois "é possível que certos argumentos subentendidos sejam compreendidos graças ao lugar que ocupam em semelhante sucessão ordenada" (Perelman e Olbrecths-Tyteca 2002 [1958], p.569).

Do mesmo modo que o exórdio cumpre função importante para a argumentação, a conclusão e o epílogo também merecem destaque, pois, o encerramento do discurso corresponde à última oportunidade que o orador tem, naquela interação, de trazer força à tese desenvolvida e de assegurar boa impressão por parte do auditório. Sem dúvida, deve-se manter o equilíbrio em termos dos argumentados já apresentados, a fim de se estabelecer coerência, posto que estes - argumentação e coerência - se aliam para o alcance da persuasão, mas as últimas palavras precisam promover mais do que isto, ou seja, o efeito de impacto alcançado por meio delas é essencial. Pode-se dizer que é um percurso necessário para que a ação política se efetive do modo como foi planejada.

Em todos os momentos em que o orador tem a chance de construir sentidos aos objetos postos no discurso, no último momento, os elementos linguísticos consistem em coengajamentos particulares pelos quais se tenta deixar no auditório uma sensação que o predisponha a pensar de um determinado ângulo e a agir no momento oportuno.

Assim, à medida que as estratégias são empregadas no desenvolvimento do discurso, por meio de argumentos centrais a partir dos quais há tentativas de convalidar a tese, ao final, o orador deve provocar em seu auditório a lembrança dos adversários, reforçar ou atenuar alguns recortes, retomando as informações julgadas capazes de servir como condutoras de tais resultados. Entre essas estratégias, discutimos a respeito do momento em que a metáfora aparece no discurso e dialoga com outras informações como um fator significativo para os processos referenciais do ponto de vista argumentativo. 


\subsubsection{Função referencial e retórica da metáfora na organização discursiva}

Tendo em vista as afirmações anteriores a respeito da importância de se levar em conta a organização discursiva no exame de possíveis efeitos de sentido, entendemos que tal posição deva também ser considerada na observação da função retórica/argumentativa e referencial da metáfora em pronunciamentos presidenciais. Seguindo nesta direção, tem-se que a metáfora pode orientar argumentativamente a partir dos efeitos que ela provoca em dados momentos da interação, já que também é assim que ocorre com a construção de objetos de discurso em redes referenciais delineadas no desenvolvimento discursivo, a partir das quais se ativa, desloca, reativa unidades cognitivas que são categorizadas e recategorizadas em um processo em que se articulam informações novas e velhas.

A sequência de informações selecionada como a preferível, bem como a escolha do léxico que as molda e produz sentido, são procedimentos que influenciam no modo como a metáfora é registrada e compreendida pelos participantes. Este entrelace de informações e de escolhas linguísticas promovem mapeamentos específicos e, por vezes, inusitados, já que o encaminhamento do discurso dá a conhecer os processos de referenciação privilegiados pelo enunciador.

A análise prévia do segmento (09), feita às páginas 151-152 deste capítulo, reforça esse pressuposto. Quando, no e pelo discurso, a relação entre Brasil e Portugal foi construída a partir da metáfora PARCERIA BILATERAL É JORNADA A DOIS, pudemos examinar que, embora haja uma estrutura já convencional de jornada, esta ganha um viés singular na medida em que é posta no discurso e interage com outros elementos textuais e cognitivos. Vimos que não se tratava de uma jornada qualquer, mas sim de uma longa e histórica, cujos obstáculos físicos puderam ser vencidos (oceano), e que tinha como ponto de chegada (efeito futuro) um destino apresentado como positivo em termos de progresso econômico, que era o objeto de discurso Brasil.

Nesse percurso discursivo, as escolhas são reveladoras de uma conduta que cria representações de mundo alinhadas à proposta de uma política externa, cujo objetivo também é o de estabelecer parcerias e, logo, tentar aproximar Estados a partir de um viés que os una, que os aproxime. O processo de referenciação dado na organização discursiva de modo metafórico revela-se como complexo por considerarmos todos os entrelaces nele existentes. Estruturas mentais são associadas a outras, mas isto não é o que apenas ocorre, pois o objeto de discurso recebe dessa e nessa associação um encaminhamento singular, produto de 
seleções linguísticas ordenadas que fornecem condições ao auditório, para que ele observe tal objeto e o associe ao momento enunciativo, aos objetivos pré-determinados do encontro, à figura de quem enuncia.

Entendemos, a partir disso, que a metáfora estrutura o discurso, mas também recebe deste toda sua complexidade - organização específica, intersubjetividade, seleções lexicais, redes referenciais, influência da situação imediata etc. Recorrer a estratégias discursivas e metafóricas envolve um olhar sobre conhecimentos prévios e locais a respeito dos discursos e dos eventos nos quais eles estão inseridos. Este é o caráter dinâmico da argumentação que se revela na prática discursiva da política e que se faz a partir dos interesses de cada participante e, nele, a metáfora insere-se. Neste viés, ao buscar apoio de seu auditório, o político tenta criar, de maneira associativa, imagens mentais de objetos de discurso que reforçam a tese delineada em seu pronunciamento.

Assim, se processos políticos podem ser construídos em termos de viagem, como examinamos no segmento (9), interessa-nos indicar que esta é singular a partir, também, das seleções linguísticas referenciais que a registram e que, de algum modo, categorizam objetos de discurso. O veículo selecionado, o destino da viagem, os participantes viajantes são objetos que moldam a metáfora e, ao mesmo tempo, são moldados por ela. Neste percurso, a argumentação faz-se presente. Trata-se de estratégias diversas que se fortalecem a cada sequência de informações apresentadas ao auditório.

Além do mais, parece-nos coerente utilizar uma metáfora, entre as várias possíveis, para indicar a construção de sentido dada na organização discursiva, partindo de um ponto de vista argumentativo. Compreendemos que a elaboração de um discurso estratégico pode ser explicada em termos de uma jornada planejada: o ponto de partida, visando o objetivo almejado (exórdio), a escolha do melhor caminho e das entidades envolvidas (narração, seleção linguístico-cognitiva), os obstáculos previstos e os já vencidos (prova, refutação), a chegada que encerra um percurso norteador de sentido (conclusão e epílogo).

Assim, os efeitos de sentido de determinados objetos de discurso que o orador quer provocar são encaminhados durante a enunciação, e o efeito da metáfora estabelece-se conforme o momento em que ela é posta em evidência. Nestes processos de referenciação metafórica, dialogam diversos elementos pertinentes à língua, à cognição e à práxis. Neste viés, propomos um esquema (figura 03), na tentativa de ilustrar o modo como entendemos que se dá o processo referencial e metafórico na organização discursiva. 


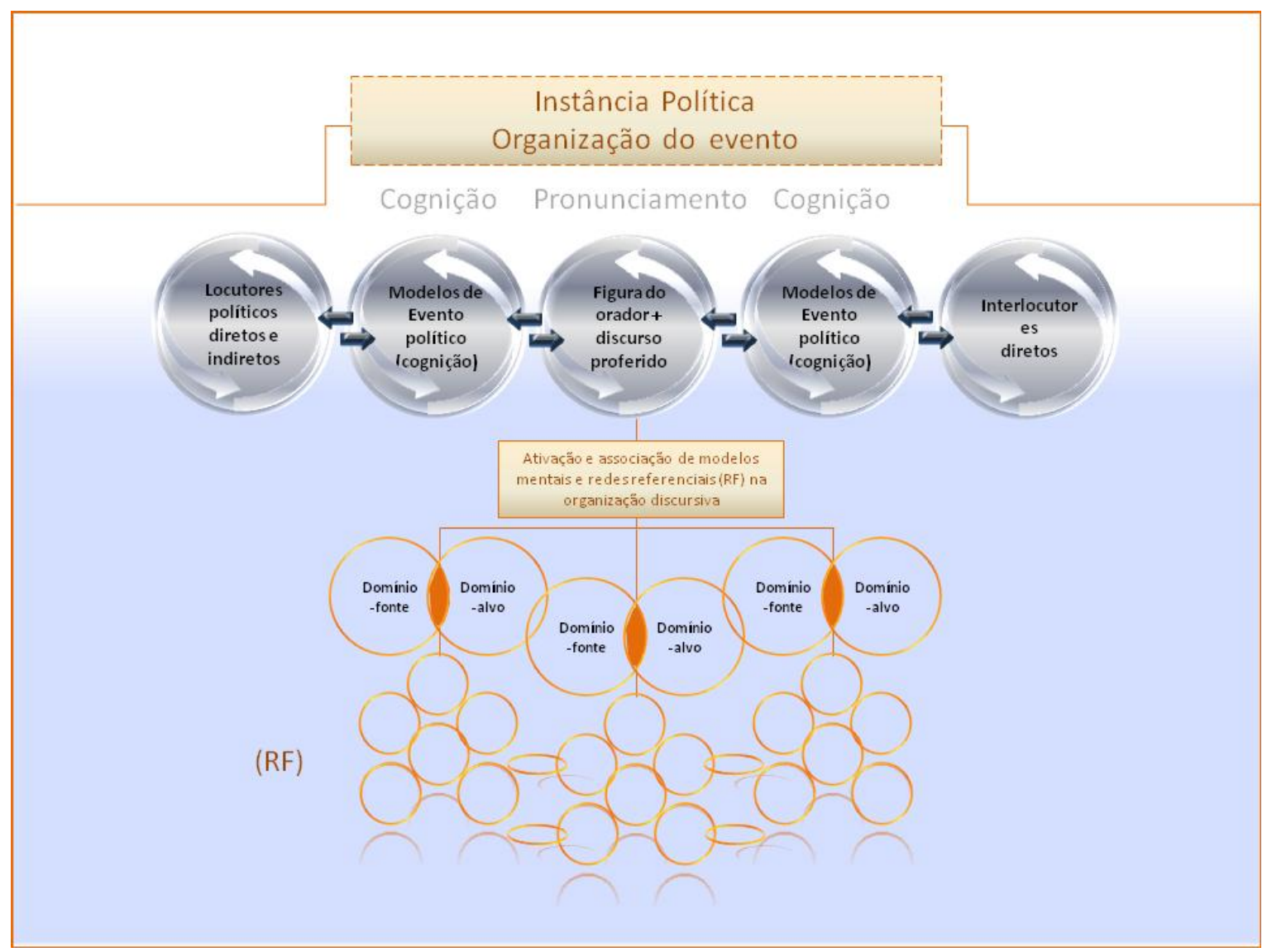

Figura 3. Esquema do processo referencial e metafórico na organização discursiva

Tal esquema representa as redes referenciais estruturadas por metáforas subjacentes, que estabelecem relações diversas entre si durante o desenvolvimento do discurso. O que é construído, neste percurso, é resultado da articulação de informações evidenciadas e deduzidas no processo discursivo, caracterizado por ser situado e desenvolvido por políticos, entre os quais, não podemos deixar de destacar, há líderes. Isto significa que participam da coprodução de sentidos chefes de Estado ou de governo, que trazem, consigo, características comuns relacionadas à liderança, que conhecem as regras que estão em jogo e, consecutivamente, os procedimentos discursivo-argumentativos adotados. A descrição dessas especificidades relacionadas aos discursos de líderes políticos será discutida a seguir.

\subsection{Metáfora e controle nos discursos de líderes políticos}

Conforme discutimos no capítulo 2, à página 98, para Charteris-Black (2007), a liderança consiste de um processo pelo qual um indivíduo-líder busca influenciar um grupo a 
chegar a um acordo ou a alcançar uma meta. Embora ela não consista em um fator específico da instância política, é evidente seu papel na organização de alguns sistemas de governo.

Seguindo nessa direção, esse estudioso afirma que o líder carismático utiliza-se de símbolos e de metáforas para conectar pontos de vista específicos e realidades sociais externas. As metáforas são selecionadas para que se alcance ou se mantenha legitimidade, a partir da apresentação de visões (ideais) e de valores. Assim, consecutivamente, elas colaboram para estabelecer controle sobre uma situação, uma vez que ajudam não somente a despertar as defesas do auditório, mas também, e principalmente, a trazer uma sensação de calmaria, de segurança perante situações que requerem mudanças de comportamento e, consecutivamente, de um estado de coisas. Tais efeitos podem promover confiabilidade, que é o que se procura em um líder.

Nestas tentativas de construir realidades discursivas e de despertar confiança, outros elementos se inserem como determinantes na produção de sentido e orientam juízos de valor àquilo sobre o que se fala e a quem enuncia, como os valores e as crenças apresentados como pessoais, a história do orador, seus comportamentos em determinadas situações etc.

Parece-nos significativo ainda salientar que, quando metáforas interagem com outras estratégicas discursivas e com as não verbais - aparência, vestimenta, gestos etc. - ganham força persuasiva. De acordo com Charteris-Black (2007), isso se deve ao fato de a multimodalidade provocar respostas dos interlocutores de maneira subliminar e também criar, provavelmente, uma imagem carismática e de poder de um político-líder, caso ele ajuste seu comportamento (linguístico, social) às expectativas dos interlocutores no momento da enunciação.

De fato, a organização do evento consiste de um fator importante para os efeitos pretendidos. Tal afirmação pode ser relacionada à configuração visual de alguns encontros, como os da ONU, em que o lugar no qual o orador pronuncia, a iluminação, a vestimenta e outros fatores não verbais despertam atenção e interesse específicos por parte de um auditório que já conhece as regras pré-estabelecidas e dão legitimidade ao orador, isto é, concede-lhe o poder dizer. Ilustremos esses pressupostos com as imagens a seguir: 


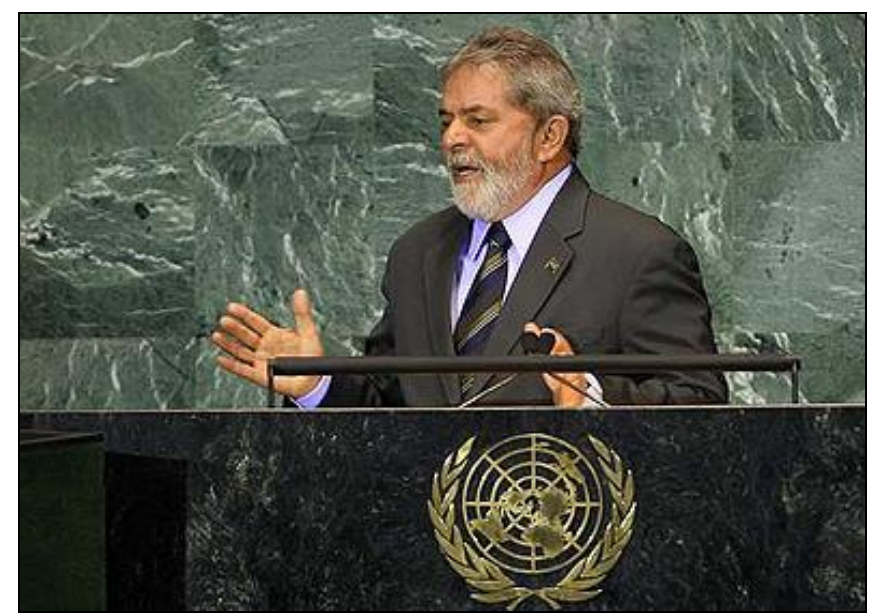

Figura 4. Ex-presidente da República Lula na abertura da $64^{a}$ Assembleia Geral da ONU (Organização das Nações Unidas) em $2009{ }^{77}$.

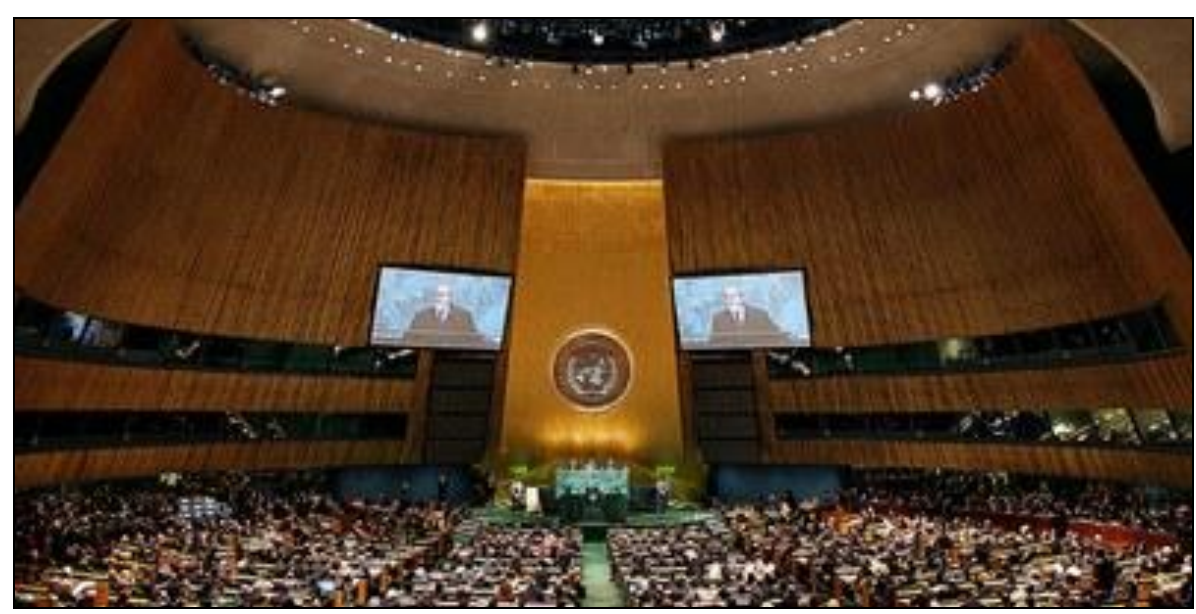

Figura 5. Organização do encontro da $\mathrm{ONU}^{78}$.

Observamos, nas figuras 04 e 05, que a organização visual do evento e o lugar ocupado pelo orador (púlpito) já conferem a este uma força pragmática. Também o dizer legitimado dá ao político o direito de exercer poder no instante de seu pronunciamento. Nestes momentos, em que o político foi legitimado para participar de interações reservadas a poucos, a prática discursiva dialoga com esses elementos externos e com as características da cognição política que as estruturam, de modo a tentar influenciar os políticos presentes, ou mesmo, os participantes indiretos.

Salientamos que a presença de um chefe de Estado em encontros internacionais deve ser pensada, em específico, como uma situação em que a argumentação política de um líder

\footnotetext{
${ }^{77}$ Disponível em http://revistaepoca.globo.com/Revista/Epoca/0,„EMI94523-15227,00.html. Acesso em 17 dez. 2012.

${ }^{78}$ Disponível em http://www.redebrasilatual.com.br. Acesso em 17 dez. 2012.
} 
caracteriza-se por especificidades. Isto porque o auditório é composto por outros líderes políticos, que também estão em busca dos interesses de seus Estados e que estão preparados para lidar com situações caracterizadas pelo alto grau de argumentatividade. Neste viés, a partir do momento que um líder enunciador foi credenciado por um povo, ele necessita agir discursivamente em busca de legitimidade no contexto global. Trata-se, pois, de assegurar o poder legitimado a partir de outras legitimações, posto que cabe ao presidente da República o papel de projetar social e politicamente a imagem do Estado, a qual envolve complexidade de relações e processos estabelecidos interna e externamente ao contexto político-social do país.

É no e pelo discurso, logo, que o político age em busca de alcançar a adesão de auditório heterogêneo, para ser reconhecido como político-líder capaz de restabelecer ou manter a ordem político-social de seu país e das questões de política externa que o envolvem. Isto se acentua em situações nas quais existem especulações acerca de mudanças sociais, políticas, econômicas, tecnológicas etc. Neste sentido, parece possível dizer que a metáfora, pode ser uma estratégia eficaz, por se tratar de "um recurso cognitivo e linguístico vital através do qual a ordem e a harmonia são restauradas porque é um meio pelo qual as pessoas comunicam mudança nelas mesmas, em seus ambientes sociais"79 (CHARTERIS-BLACK, 2008, p.1).

A despeito de o ex-presidente Lula ter sido escolhido pelo povo brasileiro para liderar e representar o país após várias tentativas e a partir de um percurso singular, entendemos que a aprovação desse então novo governo, em um contexto político internacional, tenha merecido especial atenção. Isto porque a mudança do chefe de Estado pode implicar incertezas ${ }^{80} \mathrm{e}$, portanto, cabia a Lula e sua equipe garantirem credibilidade perante um auditório global, principalmente, nos primeiros anos do mandato.

Logo, os discursos escritos do novo líder de Estado, supostamente, emergiam como ações legitimadoras não só do país, mas também de seus governantes. Neste jogo de relações de poder, em que estratégias políticas também dialogam com as expectativas de um público maior, reconhecemos o papel referenciador e retórico da metáfora, a partir dos efeitos que ela pode suscitar por estruturar pensamento e emoção.

A respeito disso, reportemo-nos, novamente, à afirmação de Charteris-Black (2008), para quem nosso plano emocional e nossa moral são mediados pelo pensamento que cria

\footnotetext{
${ }^{79}$ Tradução livre: It is a vital cognitive and linguistic resource through which order and harmony are restored because it is a means by which people communicate change in themselves, and in their social environments.

${ }^{80}$ Boa parte dos discursos de Lula, enquanto candidato à presidência da República, enfatizava a necessidade de mudança em relação ao governo anterior de Fernando Henrique Cardoso, tal como discutimos no capítulo 2.
} 
metáforas, as quais colaboram para que possamos nos adaptar às mudanças sociais e às pessoais. É neste sentido que a seleção metafórica corresponde a uma tentativa de obter ou de restaurar controle político, principalmente, quando se trata de liderança política.

Assim, a metáfora como tentativa de controle consiste, sobretudo, na construção de uma imagem de si pelo político como criador de situações boas. Ao mesmo tempo, o uso dessa metáfora servirá para construir discursivamente o oponente - um político, um grupo, um país etc. - sem o dizer, pelo pressuposto, o que serve para deslegitimar tais adversários, e reforçar a categorização positiva constituída do enunciador pelo discurso perante seu auditório.

Metáfora e discurso político entrelaçam-se, portanto, em estratégias diversas de obtenção de controle e tais procedimentos vêm sendo observados em algumas pesquisas. Entre elas, Moreno (2008), ao estudar as metáforas selecionadas por Hugo Chavéz, afirma que há recorrência de discursos de inclusão pelos quais o então presidente constrói uma cena de polarização, em que os políticos oponentes são construídos como inimigos da nação venezuelana. A justificativa da ação desse líder é endereçada não apenas a seu povo, mas, além disto, é atitude de ampla repercussão, posto que foi feita por um líder estadista de significativa importância internacional.

Pode-se afirmar que essa estratégia foi a mesma utilizada pelo ex-presidente norteamericano George W. Bush, quando construiu uma imagem de "eixo do mal", "ameaças globais", "Estados vilões" a respeito do Irã, da Coreia do Norte e do Iraque, após o ataque de 11 de setembro, em 2002. Sabemos que essa categorização perpassou o campo político, esteve presente de maneira recorrente nos discursos da mídia ${ }^{81}$. A respeito desse procedimento, observamos ser inquestionável o controle exercido por meio do discurso de um chefe de Estado, já que é prática muito observada que ultrapassa seu campo de atuação e pode criar categorizações de certa maneira recorrentes a respeito de um objeto de discurso, incluindo-o em uma categoria que se tornará relativamente estável, com a ajuda de outro dispositivo de poder, que é a mídia.

De modo geral, os líderes políticos optam por seleções linguísticas organizadas pelas quais se tornam possíveis encaminhamentos singulares que ajudam na tentativa de fazer o outro olhar para o que é evidenciado no discurso, de modo que convalide a ação do líder,

\footnotetext{
${ }^{81}$ Resultados de pesquisa que apresentamos em outro trabalho. PALUMBO, R. (2011). O olhar disciplinador nas notícias online: um enfoque argumentativo. Anais do SILEL, Uberlândia, UDUFU, v.2, n.2. Disponível em: www.ileel.ufu.br/anaisdosilel/pt/arquivos/silel2011/364.pdf. Acesso em 22 jan. 2012.
} 
sobre quem a população que o legitimou se volta, a fim de buscar o que a ela foi prometido. $\mathrm{O}$ credenciamento do país e, consecutivamente, de seu governo pode ser considerado um dos resultados delegados a Lula alcançar enquanto líder da nação brasileira. Para tanto, negociar sentido para determinados objetos de discurso é atitude significativa em termos de promoção da imagem de um Estado. Isto nos leva a discorrer, e posteriormente, explorar em nossas análises, sobre como se dá essa tentativa de construir objetos de discurso em interações políticas de âmbito global.

\subsection{Construção discursivo-metafórica da referência na política global}

No discurso político internacional, assim denominado por Chilton (2004), a percepção e a concepção de espaço geopolítico merece atenção. Por um lado, o autor afirma que, em uma concepção antropológica, a questão de territorialidade é parte intrínseca do instinto sociopolítico. Por outro, já em uma perspectiva psicológica e neurológica, está implicado o fato de o homem ter um complexo sistema sensório-motor e proprioceptivo e habilidade, entre outras, de construir e de armazenar mapas fotográficos.

Quanto à questão do discurso e da cognição, há evidências de que transferências metafóricas de domínios básicos de espaço são atuantes e merecem atenção quando se analisam discursos em interações, cuja configuração envolve fatores globais. Chilton (2004) afirma que frames geográficos são utilizados para marcar e dividir os agentes e seus territórios, cumprindo função dêitica, e para relacioná-los, no discurso, a conhecimentos mais gerais de ordem política. $\mathrm{O}$ autor examina o discurso do ex-presidente norte-americano Bill Clinton, proferido à nação em 1999, para justificar o ataque contra as tropas sérvias. Ele observa que, na formulação linguística "Meus compatriotas americanos, hoje, nossas forças armadas juntaram-se aos nossos estrangeiros da OTAN nos ataques aéreos contra as forças sérvias, responsáveis pela brutalidade em Kosovo ${ }^{82,}$, o orador apresenta as entidades da realidade discursiva de modo a marcar território (meus, nossas, forças armadas) e estabelecer suas relações, construindo o outro (as tropas sérvias) com valores negativos (forças sérvias, brutalidade).

\footnotetext{
${ }^{82}$ Tradução livre: My fellow Americans, today our Armed forces joined our NATO aliens in air strikes against Serbian forces responsible for the brutally in Kosovo.
} 
Chilton (2004, p.52) segue afirmando que:

Grupos sociais, e em particular os Estados soberanos, envolvem o domínio-fonte de espaço, enraizado na experiência de contenção e limiteajuste. Entidades sociais têm "um centro", "dentro" e "fora", as pessoas "à margem", etc. ${ }^{83}$

Como discutimos, que o homem caracteriza-se por ser um animal político (Chilton, 2004) e, por conta disto, precisa estabelecer relações sociais de tal modo que cooperação e conflito consistem em elementos constitutivos dessas atividades, as quais requerem negociações também em termos de espaços sociais e políticos, que são negociados também no discurso. $\mathrm{Na}$ arena global, não ocorre de modo diferente. A maneira como um Estado, por meio de seus governantes, constrói relações com outros e as justifica é de extrema importância para a política nacional e global e isto é influenciado pelas condições específicas de produção. E é este processo ligado à construção metafórica dos objetos de discurso, em específico, que consideramos significativo nos ater por conta dos propósitos deste trabalho e das características de nosso corpus.

Entendemos que o orador político tenta criar condições, para que o auditório visualize pessoas, situações etc. que não fazem parte de seu dia a dia por meio de um recorte avaliativo. Tal procedimento está relacionado ao processo referencial do discurso político e das metáforas subjacentes, a partir dos quais agentes e processos políticos tornam-se objetos passíveis de negociação de sentido a partir do momento que são ativados na organização textual-discursiva.

Tendo em vista que ocorrências linguísticas, quando metafóricas, ativam, ao mesmo tempo, referências duplas, sendo que uma delas pertence a um domínio-fonte, parece-nos coerente dizer que a proposta de sentido do discurso encontra, na metáfora, uma maneira de ativar um conhecimento prévio do auditório que o orientará na construção dos objetos de discurso, conforme o que se entende como preferível em termos de sentido a eles atribuídos.

Tomamos o processo de referenciação, em que a metáfora está imbricada, como fio condutor de construções múltiplas de sentido, pelas quais percepções sociais e culturais se

\footnotetext{
${ }^{83}$ Tradução livre: Social groups, and in particular sovereign states, involve the spatial source domain rooted in the experience of containment and boundary-setting. Social entities have "a centre", "insiders" and "outsiders", people "on the margins", etc.
} 
articulam para que se constitua certa representatividade de um país que está em foco. O Brasil-parceiro, o Brasil-pessoa, o governante-guerreiro são categorizações oriundas de um processo associativo reiterado na dinâmica discursiva que possibilita aproximar o que, de um ponto de vista territorial e conceitual, pode estar distante. Por vezes, acrescentamos, é preciso aproximar para legitimar.

Nesta acepção, os pronunciamentos feitos por chefes de Estado ou de governo servem como interface também entre instâncias políticas; recebem, pois, características gerais do discurso político e, ao mesmo tempo, particularidades, principalmente, em relação à construção de objetos de discurso os quais são apresentados para um público que, por vezes, não tem contato direto, ou possui pouco e específico (físico) com eles, como é o caso de se falar sobre um povo para um grupo de líderes políticos na ONU.

É neste sentido que discutimos e buscamos compreender, especificamente, o entrelace entre metáfora e discurso político global, sobretudo, em relação às condições específicas dessas produções, entre as quais nos debruçamos sobre aquela em que o chefe de Estado, Lula, visita outros, a fim de promover a imagem de seu país, de criar/reforçar alianças de fazer parte de grupos específicos etc.

Embora saibamos que a questão da distância se torne relativa, atualmente, por conta da globalização, da emancipação de tecnologias da comunicação, que dão oportunidade aos indivíduos de conhecerem e de representarem outras nações a partir de um viés, parece-nos possível dizer que os discursos pronunciados por um presidente da República, e todos os fatores neles envolvidos, cumprem papel significativo na orientação de imagens de um povo e de seu governo, até porque o exercício da diplomacia a isto recorre, a fim de garantir e/ou ampliar a participação do país na política internacional.

Levando em conta tal afirmação, pode-se dizer que as imagens que se pretendeu criar a respeito do Brasil muito devem às anteriormente constituídas, ora pela instância midiática ora pelos governos anteriores. Se a proposta do governo Lula foi a mudança na política nacional e na internacional, como assim ele enunciou em seu discurso de posse, subentendemos que há um entrelace de um "Brasil-velho" e um "Brasil-Novo"; objetos de discurso, entre outros, que foram negociados nos vários pronunciamentos feitos pelo expresidente da República.

De fato, algumas metáforas e modelos mentais de contextos políticos inscrevem-se nos discursos que circulam nessas práticas políticas globais, como já discutimos. Contudo, 
sabemos que muito é preciso explorar a respeito de como elas variam, ou não, em termos de seleção do domínio-fonte, do domínio-alvo e das categorizações de objeto de discurso que são estruturadas pela relação desses domínios, uma vez que estão em jogo diversas culturas, regimes políticos, idiomas e suas traduções.

De modo geral, neste Capítulo, discutimos a utilização da metáfora conceptual no discurso político e seu papel argumentativo; discorremos sobre os efeitos que, por meio dela, líderes políticos vêm tentando suscitar em seus auditórios. Justamente por servir a tal propósito, no campo da política, associações de domínios díspares estão sendo privilegiadas e estruturam categorizações de objetos de discurso diversas que se moldam às estratégias selecionadas e dá a conhecer realidades discursivas repletas de intencionalidades políticas. Apresentadas as discussões teóricas até aqui, no capítulo a seguir, passamos à análise dos pronunciamentos do ex-presidente da República Luís Inácio Lula da Silva. 


\section{CAPÍTULO IV}

ANÁLISES DO CORPUS 
Neste capítulo, procedemos ao exame do corpus selecionado. Como procedimento metodológico, selecionamos a análise qualitativa, sem desprezarmos as ocorrências quantitativas que nos fornecessem pistas do encaminhamento argumentativo efetivado pelo viés dos processos referenciais e da metáfora. Nesta acepção, julgamos significativo salientar que não nos detivemos sobre todas as seleções metafóricas e referenciais, presentes nos enunciados que compõem nosso corpus, em razão de serem inúmeras. Buscamos por uma representatividade, que nos mostrasse o encaminhamento sociocognitivo e argumentativo da metáfora e da referenciação, nas várias etapas do processo discursivo.

Organizamos o corpus de modo a selecionar pronunciamentos voltados aos tópicos, propostos pelo governo como primordiais para a agenda internacional do ex-presidente da República Luis Inácio Lula da Silva, e organizamo-lo da seguinte maneira neste capítulo: 4.1. Construção discursivo-metafórica da justiça social e da proposta de mudança política; 4.2. Metáfora e processo de referenciação nas negociações bilaterais e multilaterais; 4.3. Processos referencial-metafóricos da corrupção e da moralidade.

\subsection{Construção discursivo-metafórica da justiça social e da proposta de mudança política}

\subsubsection{Fórum Econômico Mundial (Davos, 2003)}

Em 2003, em Davos, durante seu pronunciamento, o ex-presidente da República Luis Inácio Lula da Silva defende a tese de haver necessidade de ação política para mudar situações econômicas de ordem internacional - como mais participação de seu governo no comércio internacional, em específico, nas exportações, impedimento de evasão ilegal de recursos etc. - e diz que tais mudanças são significativas para que seja possível alterar o quadro de desigualdade social do mundo e do Brasil. Lula argumenta que seu governo toma diversas medidas com o objetivo de diminuir a miséria do país, no entanto, as relações de comércio internacional vigentes podem impedir o alcance pleno dessas metas. A partir desta observação, debruçamo-nos, especificamente, sobre a organização e o encaminhamento de sentido dado à situação social e à proposta política enunciadas.

No exórdio do discurso do ex-presidente, examinamos que já se inicia a apresentação da tese e observamos a seleção de um domínio-fonte central que norteia um encaminhamento de sentido voltado para a questão da proposta de ação política, que é o de CONSTRUÇÃO: 
Boa tarde.

Estou chegando, como vocês sabem, diretamente de Porto Alegre, onde participei do Fórum Social Mundial, e falei a dezenas de milhares de pessoas sobre os mesmos assuntos que pretendo tratar aqui.

A Reunião Anual do Fórum Econômico Mundial tem como tema central $a$ construção da confiança. Sinto-me muito à vontade com esse tema. Sou depositário da confiança do povo brasileiro, que me atribuiu a responsabilidade de conduzir um país de 175 milhões de habitantes, uma das maiores economias industriais do planeta. Mas um país que convive, também, com enormes desigualdades sociais.

Esse segmento evidencia a base cognitiva (construção) que o político utiliza para buscar apoio do auditório em questão. Representações sociais são delineadas a partir da noção de construção evidenciada na seleção lexical que se faz presente nesse segmento - "construção da confiança" (linha 10). A organização discursiva comprova tal observação, na medida em que o orador segue apresentando outras formulações relacionadas à ideia de construção e também à de reforma, como em (13) e (14):

Aqui, em Davos, convencionou-se dizer que hoje existe um único Deus: o mercado. Mas a liberdade de mercado pressupõe, antes de tudo, a liberdade e a segurança dos cidadãos.

20 Respondi, de forma serena e madura, aos que desconfiaram dos nossos compromissos, durante a campanha eleitoral. Na Carta ao Povo Brasileiro, reafirmei a disposição de realizar reformas econômicas, sociais e políticas muito profundas, respeitando contratos e assegurando o equilíbrio econômico.

A construção de uma nova ordem econômica internacional, mais justa e democrática, não é somente um ato de generosidade, mas, também, e principalmente, uma atitude

Em (14), a formulação metafórica “A construção de uma nova ordem econômica internacional", recategorizada, posteriormente, como "um ato de generosidade" e "uma atitude de inteligência política", encaminha um olhar específico sobre a proposta de ação política internacional e de seus possíveis agentes, qualificando-os com atributos, supostamente, valorizados socialmente. Se levarmos em conta que esses pronunciamentos oficiais alcançam um número significativo de pessoas, por ficarem disponíveis no site do governo brasileiro e por serem noticiados pela mídia internacional, podemos afirmar que tais 
recategorizações reforçam e orientam o auditório geral a ver como pertinente, viável, a ação política proposta, principalmente, a partir dos atributos "inteligência" e "generosidade".

Seguindo por esse viés, quando se apresenta o conceito de processo político em termos de construção, pode-se dizer que se faz menção à ideia de transformação, de mudança. A passagem de um estado A para um B - da não existência para a existência, ou vice-versa; da incompletude para a completude; do projeto para sua realização - implica a seleção de etapas que se articulam no percurso da transformação. É neste encaminhamento de sentido que um discurso pode evidenciar agentes transformadores, cocriadores, que possibilitam a concretização do que foi projetado. Assim, entendemos estar organizado o domínio da construção.

Já em relação ao conceito de reforma, este implica mudança de algo já existente. Trata-se de melhorar uma organização. Neste viés, no pronunciamento, recorre-se à proposta de alterar a conjuntura apresentada a respeito da ordem econômica mundial vigente. Os efeitos de sentido, no discurso, resultam do entrelace entre as características específicas de dois domínios (o da reforma e o da política), ligados ao da economia internacional.

Além dos agentes da construção e da reforma, na organização de seu conceito, existem os objetos a serem modificados, ou mesmo criados, e as ações pelas quais tal tarefa é executada. Esta precisa de recursos, utilizados de modo estratégico. A respeito deste objeto da construção, como vimos em (14), ele corresponde à formulação "uma nova ordem econômica internacional, mais justa e democrática". Para dar sentido ao que, a princípio, é abstrato, por não ter sido vivenciado, o orador procede à seleção de metáforas ontológicas e orientacionais, como busca para viabilizar o entendimento do abstrato a partir do concreto. Tal procedimento consiste de um processo interacional e dinâmico de intercompreensão (objetivo retórico docere), a partir da qual se torna possível chegar aos lugares comuns em termos de olhares específicos sobre situações políticas, econômicas e sociais.

Tais metáforas, ativadas no processo de referenciação, merecem nossa atenção. Entre elas, primeiramente, examinamos "a metáfora do contêiner" (Reddy, 1979; Lakoff e Johnson, 1980), que é selecionada no discurso de Lula, cumprindo papel de estruturar e de viabilizar a ideia da necessidade de transformar, de mudar situações específicas, na medida em estas são mostradas como impróprias. Neste viés, a organização específica que se dá ao mundo social por meio da metáfora do contêiner - e de certas seleções lexicais que dão propriedades aos objetos de discurso e vão modelando-os - permite que o interlocutor crie uma imagem de desigualdade e, com isto, aceite a ideia de necessidade de mudanças. É deste modo que o 
discurso orienta argumentativamente, quando, por meio dele, leva-se à presença do auditório um recorte avaliativo sobre aquilo que se refere, assim como postulam Perelman e OlbrechtsTyteca (2002 [1958]). Observemos as partes destacadas:

(15)

Mais de dez anos após a derrubada do Muro de Berlim, ainda persistem "muros" que separam os que comem dos famintos, os que têm trabalho dos desempregados, os que moram dignamente dos que vivem na rua ou em miseráveis favelas, os que têm acesso à educação e ao acervo cultural da Humanidade dos que vivem 70 mergulhados no analfabetismo e na mais absoluta alienação.

Observa-se, primeiramente, que o objeto de discurso "muros que separam" (metáfora ontológica) recupera conhecimentos específicos do domínio "reforma", que pode ser associado à ideia de ação política. Tal procedimento reforça o cenário metafórico apresentado, de modo a enfatizar a necessidade de alterá-lo, ou seja, de derrubar o muro, que divide economicamente e socialmente o mundo.

Posteriormente, outros objetos de discurso são selecionados - "os que comem dos famintos, os que têm trabalho dos desempregados, os que moram dignamente dos que vivem na rua ou em miseráveis favelas, os que têm acesso à educação e ao acervo cultural da Humanidade dos que vivem mergulhados no analfabetismo e na mais absoluta alienação" - e favorecem essa ideia de divisão, de agrupamento, de modo a possibilitar que o interlocutor construa uma imagem de espaços divididos (dentro-fora; inclusão e exclusão social) e de hierarquias sociais (alto-baixo), viabilizada pela noção do contêiner, a qual opera junto às metáforas orientacionais.

Julgamos importante salientar que, ao se referir, especificamente, à situação social do Brasil, o orador também apresenta as associações abaixo-acima, frente-atrás, relacionando-as à metáfora da família - de modo a favorecer valores concretos relacionados a direitos e a deveres dos seres humanos, como solidariedade etc.:

[...] um país que convive, também, com enormes desigualdades sociais (linhas 1213) (coisificação) 
[...] os enormes problemas que temos pela frente (linhas 16-17) (coisificação; frente-atrás)

[...] os mais de 45 milhões de brasileiros que vivem abaixo da linha da pobreza. (linha 28) (acima-abaixo)

[...] a fome, que atinge dezenas de milhões de irmãos e irmãs brasileiras. (linhas 28-29) (família)

Tais procedimentos permitem-nos afirmar que, durante seu pronunciamento, o enunciador apresenta elementos que reforçam a tese defendida. Com efeito, as metáforas são relacionadas - construção (metáfora central), relação pessoa (família) e espaço (contêiner, frente-atrás, acima-abaixo, dentro-fora) - e colaboram para dar ênfase à proposta enunciativa, possibilitando a criação de redes referenciais específicas e complexas, cujos sentidos metafóricos só podem ser observados na dinâmica textual-discursiva.

Isso corrobora com a afirmação apresentada, neste trabalho (Cf. p.127), a respeito do dizer metafórico favorecer, no universo discursivo, mapeamentos particulares, que estão alinhados à tese defendida pelo locutor. Tal procedimento ocorre em várias passagens do discurso. A respeito disto, observemos mais um segmento, em que a proposta de ação continua sendo apresentada em termos de construção ou de reforma e reforçada pela seleção de objetos de discurso, nos quais é possível observar a existência da metáfora de contêiner:

(17)

Quero convidar a todos os que aqui se encontram, nessa montanha mágica de Davos, a olhar o mundo com outros olhos. É absolutamente necessário reconstruir a ordem econômica mundial para atender aos anseios de milhões 90 de pessoas que vivem à margem dos extraordinários progressos científicos e tecnológicos que um ser humano foi capaz de produzir.

Em (17), a formulação, às linhas 89-91, “milhões de pessoas que vivem à margem dos extraordinários progressos científicos e tecnológicos que um ser humano foi capaz de produzir" (relação dentro-fora) oferece outras informações sobre o objeto de discurso relacionado às seleções linguísticas “os famintos", "os desempregados” etc., presentes na rede referencial examinada em (15), na qual pudemos detectar a construção de uma imagem do grupo dos "desprivilegiados" a partir da noção de divisão de território da metáfora de contêiner, reforçada pela seleção "Muros que separam". Essas seleções colaboram na 
argumentação do discurso também pelo fato de elas acionarem valores compartilhados entre os participantes.

É nessa direção que o discurso apela à regra da justiça e convalida sua tese de modo a dar efeito de coerência e racionalidade a partir de valores aceitos socialmente, como já postularam Perelman e Olbrechts-Tyteca (2002 [1958]) e discutimos às páginas 154-155 deste trabalho.

Mais do que isso. Razão e emoção caminham lado a lado, uma vez que se torna possível, pelas categorizações efetivadas, ora despertar uma ora, a outra. Relacionamos este procedimento às afirmações de Charteris-Black (2005, 2009), para quem o potencial argumentativo da metáfora consiste de possibilitar que argumentos e posições ideológicas sejam apresentados de maneira a alcançar ou a reforçar emoções e dar integridade a quem enuncia. Pode-se afirmar, pelas pistas linguísticas examinadas, que ocorre tal tentativa nos segmentos examinados.

Também cumpre tal função argumentativa o objeto de discurso "Montanha Mágica de Davos", ainda em (17), às linhas 87-88. No processo de referenciação, a seleção de certos objetos de discurso propicia que se ativem informações específicas, as quais serão articuladas no processo discursivo, de modo a privilegiar um encaminhamento cognitivo que é importantíssimo para que se dê coerência ao que se diz e, consecutivamente, é significativo para a argumentação. Assim é que consideramos ser essa formulação capaz de fazer que o auditório ative um frame cognitivo, correspondente à história do livro A Montanha Mágica ${ }^{84}$, escrito por Thomas Mann em 1924, em razão de dialogar com o tópico discursivo que se desenvolve no pronunciamento.

De modo sucinto, relembremos que o romance alemão foi tema de debates por retratar uma história, passada em Davos, na qual a questão sobre o sofrimento humano é evidenciada, bem como a necessidade de mudança de uma humanidade futura, em que valores conservadores são questionados. O protagonista, Hans Castorp, jovem engenheiro naval alemão de uma família conservadora, por ficar internado em um sanatório localizado nos Alpes Suíços, por conta de uma tuberculose pulmonar, passa a refletir a respeito de política, de artes, de culturas, de noção de tempo e das fragilidades humanas. Assim, ao se distanciar de sua vida habitual (que ficou "abaixo" da montanha) e ao entrar em contato com

\footnotetext{
${ }^{84}$ No alemão: Der Zauberberg.
} 
sofrimentos humanos, decorrentes da doença, o jovem apresenta um olhar humanizado sobre os demais pacientes e passa a ajudá-los.

Outros personagens dão a conhecer posicionamentos distintos, tais como as ideias liberais e as conservadoras, representadas, respectivamente, pelo humanista Lodovico Settembrini e pelo jesuíta totalitário Leo Naphta.

Salientamos ainda o que diz o autor (1924), em seu propósito:

No entanto, não será o caráter de antiguidade de uma história tanto mais profundo, perfeito e lendário, quanto mais próxima do presente ela se passar? Além disso, poderia ser que também sob outros aspectos a nossa história, pela sua natureza íntima, tenha isto e aquilo em comum com a lenda.

Parece-nos coerente afirmar que se reitera esse posicionamento do escritor no pronunciamento sob análise. Estabelece-se relação cognitiva entre literatura e política, em específico, entre alguns personagens da história e os participantes da reunião em Davos. O lugar no qual Hans Castorp mudou a maneira de entender o mundo é relembrado pela formulação "Montanha Mágica de Davos", de modo a convalidar a tese de necessidade de mudança de uma postura política tradicional para uma inovadora, humanizada, que deve ser feita também por meio da transformação pessoal de cada dirigente. Nesta parte do pronunciamento, a referenciação possibilita a criação de imagens específicas dos políticos presentes na interação, em um processo no qual certos conhecimentos de domínios diferentes são associados. Infere-se, não se explicita.

Consideramos que esse procedimento corresponde a uma crítica velada, que fortalece a argumentação do discurso. Nesta direção, retomemos Aquino (2005), para quem a acusação indireta exime de culpabilidade quem a formula. Além do mais, podemos entender que a metáfora colabora para tal efeito, em razão de agir por meio de um processo de inferência, no qual se sugere, mas não se afirma diretamente. Em razão de se tratar de política internacional, as relações de forças veladas imprimem-se nos discursos, estruturados por associações de domínios múltiplos, assim como pudemos depreender em (17).

Ainda em relação ao segmento (17), observa-se que há uma orientação espacial na maneira como se constrói o lugar em que o encontro ocorre - uma aldeia pequena situada nos Alpes Suíços, vista como luxuosa - assim como os participantes (líderes empresariais e 
políticos). Ao apresentar a noção espacial "alto-baixo", faz-se juízo de valor (Lakoff e Johnson, 1992 [1980]) - uma vez que há, geralmente, supervalorização do alto em contraposição do baixo - e coloca em evidência o poder desses políticos para agir e mudar um estado de coisas.

Assim, a partir da análise de tais estratégias de referenciação, pode-se observar o encaminhamento de sentido metafórico do discurso que, o tempo todo, é condizente com a ideia de necessidade de mudança política, econômica e social defendida por Lula em seu exórdio. Na sequência do pronunciamento, o objeto de discurso relacionado ao grupo dos excluídos ganha outras propriedades e ajustes, tal como ocorre às linhas 110-111:

(18)

A mudança que buscamos não é para um grupo social, político ou ideológico. Ela

110 beneficiará mais os desprotegidos, os humilhados, os ofendidos e os que, agora, vêem com esperança a possibilidade de redenção pessoal e coletiva. Esta é uma causa de todos. Ela é universal por excelência.

Mais uma vez, as expressões referenciais reforçam a ideia de um mundo dividido em territórios com limites. Ao mesmo tempo, é possível examinar, no segmento 18, que as seleções lexicais com função de retomada - "os desprotegidos, os humilhados, os ofendidos e os que, agora, vêem com esperança a possibilidade de redenção pessoal e coletiva" (linhas 110-111) - vão dando ao objeto de discurso certos recortes e qualificações, de maneira a reiterar a ideia de haver vítimas e, também, de questionar os valores humanitários daqueles que detêm poder político-econômico para agir e mudar tal situação social.

De fato, a ativação de alguns valores concretos deve-se à noção de agentes expostos em espaços diferenciados e tratados com posições sociais desniveladas, convalidando a ideia de falta de igualdade. $\mathrm{O}$ orador faz seleções lexicais, pelas quais se pode criar efeito de existência de seres humanos abaixo dos demais ou fora da sociedade. Retomemos algumas formulações que permitem observar efeitos dessa ordem: "os que vivem mergulhados no analfabetismo e na mais absoluta alienação" (linhas 66-70), “45 milhões de brasileiros que vivem abaixo da linha da pobreza" (linha 28), "milhões de pessoas que vivem à margem dos extraordinários progressos científicos e tecnológicos que um ser humano foi capaz de produzir" (linhas 8991), “os humilhados" (linha 110).

Esse procedimento pode ser entendido como mais uma estratégia argumentativa, na medida em que, por um lado, continua favorecendo a imagem de integridade de Lula, que 
assume um papel de defensor do grupo desprestigiado, e, por outro, pode suscitar certas emoções no auditório, de modo a fazê-lo agir conforme a proposta do ex-presidente.

Além do mais, como discutimos às páginas 134-136 deste trabalho, em consonância com os estudos de Kovecses (2003) e de Charteris-Black, 2011, a metáfora ativa um sistema de valores e de crenças, que funciona como orientador avaliativo. Muitas vezes, tais ativações podem suscitar no auditório certas emoções, em razão de haver possibilidade de despertar sensações múltiplas.

Ainda neste viés, segundo Kovecses (2003), metáforas orientacionais - tais como FELICIDADE É PARA CIMA, TRISTEZA É PARA BAIXO - podem conduzir a determinadas emoções, na medida em que há valores subjacentes nelas, enraizados em certas culturas. Seguindo nesta direção, podemos dizer que o modo como se categorizam alguns seres humanos, enfatizando as noções abaixo-acima, dentro-fora, conduz à ideia de felicidadetristeza, por parte daqueles que se coadunam com esse modo de entender as emoções. De qualquer modo, detecta-se que existe uma busca por soar certo (Charteris-Black, 2011), promover impacto emocional.

Ao término do discurso, nota-se um encaminhamento que, ao mesmo tempo, recupera a tese defendida e indica uma busca por assegurar boa impressão por parte do auditório. Observemos, da citação a seguir, os elementos destacados em itálico:

[...] proponho a formação de um fundo internacional para o combate à miséria e à fome nos países do Terceiro Mundo, constituído pelos países do G-7 e estimulado pelos grandes investidores internacionais. Isso porque é longo o caminho para 120 a construção de um mundo mais justo e a fome não pode esperar.

Meu maior desejo é que a esperança, que venceu o medo, no meu país, também contribua para vencê-lo em todo o mundo. Precisamos, urgentemente, nos unir em torno de um pacto mundial pela paz e contra a fome.

Como mencionamos no capítulo 3 deste trabalho, o lugar em que a metáfora aparece corresponde a um fator significativo, em razão de haver etapas que servem como orientadoras de raciocínio no decorrer do discurso. Nesta acepção, examinamos que se associa a noção de construção à jornada e à guerra, em um entrelace entre metáforas a partir do qual o olhar do auditório ora se encaminha para a força da proposta do orador - "proponho a formação de um fundo internacional para o combate à miséria e à fome nos países do Terceiro Mundo, constituído pelos países do G-7 e estimulado pelos grandes investidores internacionais" (linhas 117-119) - ora convalida a necessidade de unir para construir, embasado na ideia de 
jornada longa - "Isso porque é longo o caminho para a construção de um mundo mais justo e a fome não pode esperar" (linhas 119-120). Além do mais, a personificação da fome - "a fome não pode esperar" (linha 120) - é um procedimento que não só traz à presença do auditório sua existência, mas também a aproxima pelo viés da metáfora ontológica.

Ainda, temos que a metáfora do contêiner estrutura a rede referencial do pronunciamento e está diretamente relacionada às metáforas da reforma e da construção. É a partir da organização dada a certa situação social pela ideia de contêiner e do modo como se apresentam tais divisões que a tese de agir em prol de mudar ganha visibilidade no enunciado.

Observamos que, já a partir das primeiras análises, vai-se delineando a existência de uma cadeia metafórica (metáfora da construção, do contêiner etc.) nos segmentos analisados, que possibilita redes referenciais específicas, as quais, na dinâmica textual-discursiva, podem orientar o olhar do auditório, encaminhando um determinado sentido às situações sociais postas em discurso, e fazer que estes interlocutores se tornem sensíveis à adesão da proposta de mudança de ação política, apresentada pelo ex-presidente da República Luis Inácio Lula da Silva.

\subsubsection{Financiamento à Guerra Contra a Fome (Davos, 2005)}

No dia vinte e oito de janeiro de 2005, houve uma sessão especial em Davos, intitulada "Financiamento à Guerra Contra a Fome". Em seu discurso, Lula discorre a respeito da necessidade de "algo novo", a partir do qual fosse possível alterar a situação de pobreza e de fome. Em seu exórdio, em que há pistas de que se tratou de uma improvisação (Cf. linhas 0506), o orador apresenta sua tese:

(20)

05 Eu trouxe um texto que vou deixar de lado para entrar num debate que começou, não por mim, mas pelos colegas que estão aqui.

Eu penso que nós estamos começando um novo século e eu penso que é preciso, sobretudo, todos nós, governantes, empresários, intelectuais, sindicatos, igrejas, artistas, pararmos para pensar no que aconteceu no século passado, para saber se

10 vamos continuar fazendo as mesmas coisas que fizemos no século passado ou se vamos, com a criatividade e com a nossa inteligência, pensar em fazer algo novo. $O$ dado concreto é que, no século passado, a distância entre os países pobres $e$ o países ricos não diminuiu, aumentou, ou seja, quem era rico, ficou mais rico, $e$ quem era pobre ficou mais pobre. 
A formulação "vamos continuar fazendo as mesmas coisas que fizemos no século passado" (linha 10) é indicativa de um olhar voltado às ações executadas por determinados agentes - "todos nós, governantes, empresários, intelectuais, sindicatos, igrejas, artistas" (linhas 08-09) - em movimento e inseridos em uma situação (tempo presente do discurso), direcionando à ideia de líderes que estão agindo. Nesta acepção, retomamos o pressuposto de Lakoff e Johnson (1999), discutidos à página 149-150 deste trabalho, para quem os indivíduos entendem o tempo em termos de movimento e pela percepção de mudança. Mencionamos que se torna possível motivar um auditório a partir da maneira como o orador ativa em seu discurso a orientação de passado, de presente e de futuro. Isto porque provocar a ação implica fazer o outro compreender que determinada direção o levará a um estado de coisas promissoras ou não. Assim, o que ele encontrará em sua frente poderá fazê-lo pensar em seguir o mesmo caminho ou alterá-lo.

Sobre o pronunciamento sob análise, consideramos haver uma busca por motivação retórica/argumentativa pelo viés da metáfora do percurso, que permite a construção de uma visão do passado, do presente e do futuro a respeito do quadro econômico e social do mundo global. Tal observação pode ser pelo exame de outras partes do pronunciamento, em que aparecem formulações, a partir das quais se observa a ideia de direção, de percurso (passado e futuro), entre elas, destacamos: “eu validada penso que é importante nós termos a certeza de que, mesmo a política de doação de recursos, feita durante o século passado, é muito dispersa, ela não tem uma coisa homogênea, não tem direção. Então, o dinheiro se perde por si só (linhas 22-24); Quando nós levantamos a questão da fome, aqui, em Davos, ano passado, ou melhor, em 2003, acho que tivemos um relativo avanço (linhas 25-26); E o símbolo maior do avanço (linha 26); uma coisa que fosse dirigida aos países mais pobres” (linhas 38-39).

Em relação ao segmento (20), o processo de referenciação dá a conhecer os responsáveis pela mudança ou pela permanência da situação de fome mundial. Isto porque a seleção "todos nós" opera como termo que une as pessoas categorizadas por associação. Trata-se, portanto, de anáforas indiretas, pelas quais, no desenvolvimento do discurso, ocorre um tipo de associação cognitiva entre objetos de discurso - governantes, empresários, intelectuais, sindicatos, igrejas, artistas - que pode levar à ideia de um só grupo (os responsáveis), a partir do momento em que se ativa o objeto "Todos nós" e procede-se ao seu desmembramento.

Em consonância com Chilton (2004), página 117 deste trabalho, observamos que selecionar determinadas formulações que coadunam com os valores políticos corresponde a 
uma atitude, pela qual se torna possível construir uma imagem pública alinhada às expectativas de um auditório, o qual também pode tomar decisões a partir do sistema de crenças ativado e relacionado a modelos mentais sobre os atores do campo político. É o que ocorre no segmento analisado, quando o procedimento recai sobre a aproximação de alguns agentes por meio da noção de um só grupo, que deve assumir responsabilidades específicas que levem em conta o valor dos direitos humanos.

Nessa direção, ao indicar duas posturas (a velha e a nova), o orador procede à construção das consequências de atitudes passadas e dos possíveis efeitos futuros das atitudes novas. Primeiramente, é à situação social atual (presente do discurso) que o ex-presidente da República se volta. A partir da formulação "O dado concreto" (linha 12), podemos examinar a categorização de dois grupos inseridos em espaços cada vez mais distantes entre si: "os países pobres" e "os países ricos".

A respeito da situação social (momento presente) construída discursivamente, temos que, quando tal entidade se torna objeto, o orador a menciona, quantifica-a, dá-lhe propriedade e avaliação. À página 37, vimos, com Vereza (2007, p.121), que as metáforas ontológicas e orientacionais colaboram para que o ser humano dê certo sentido a um objeto por meio de uma "interferência cognitiva". Neste processo, há possibilidade de organizar experiências e situações e atribuir-lhes caracterizações, as quais permitem olhares enviesados sobre aquilo que não seria possível apreender sem ativar conhecimentos específicos do homem e de sua relação com o mundo.

No pronunciamento sob análise, é assim que metáforas ontológicas e orientacionais colaboram para que se visualize, que se aproxime de um auditório certa imagem da situação em pauta. As categorias-contêiner, por exemplo, a partir do que se apresenta nas seleções lexicais, fornecem pistas de uma construção discursiva e metafórica de um mundo dividido em dois blocos, permitindo que se reconheça que o valor de igualdade não é seguido. Neste viés, a rede referencial vai sendo constituída da seguinte maneira: rico, mais rico (uma vez), pobre, mais pobre (uma vez), países pobres (cinco vezes), países mais pobres (três vezes), países ricos (quatro vezes), quem está com fome (uma vez), quem está comendo (uma vez), aqueles que não estão comendo (uma vez). A recorrência destes termos possibilita que se compreenda a noção de divisão, relacionada ao resultado das ações indicadas como "as mesmas coisas que fizemos no século passado". Assim é que o orador cria efeito de um futuro igual, caso as mesmas atitudes sejam mantidas. 
O olhar voltado ao "algo novo", por sua vez, é associado, posteriormente, à proposta do orador, a qual consiste na criação de um fundo, conforme se observa no segmento (21):

\section{$[\ldots]$}

35 Eu propus que se criasse um fundo em função das transações de armas no mundo. Mas poderia ser um fundo sobre transações financeiras, poderia ser um fundo sobre comércio mundial, poderia ser um fundo sobre o dinheiro que está nos chamados "paraísos fiscais". Uma coisa que fosse substancialmente forte, uma coisa que fosse dirigida aos países mais pobres, ou seja, que nós pegássemos os países mais pobres, junto com organismos multilaterais, com os países coordenando a aplicação de recursos, a começar pela educação, a começar pela saúde, a começar pelo investimento em agricultura, no microcrédito. Coisas que pudessem dar a certeza que daqui a 10,15 ou 20 anos aquele país que recebeu o auxílio não seria mais um país que precisasse ser ajudado, porque, veja, quando um país importante se dispõe a dar um fundo para ajudar a combater a AIDS, em qualquer país do mundo, mas esse país tem que comprar o remédio do país que está dando o financiamento, ou seja, muito mais para ajudar os laboratórios do que para ajudar os que estão com AIDS, as coisas não funcionam.

Em (21), a proposta de Lula vai sendo delineada: “um fundo, um fundo sobre transações financeiras, um fundo sobre comércio mundial, um fundo sobre o dinheiro que está nos chamados 'paraísos fiscais', uma coisa que fosse substancialmente forte, uma coisa que fosse dirigida aos países mais pobres, coisas que pudessem dar a certeza que daqui a 10,15 ou 20 anos aquele país que recebeu o auxílio não seria mais um país que precisasse ser ajudado".

Embora possamos observar que as formulações pertinentes à proposta sejam nomeadas por indefinições, estas ganham corpo pela utilização de metáforas orientacionais e ontológicas, as quais sustentam a metáfora central do percurso. "Um fundo" consiste de uma seleção norteadora de espaço de corpos, a partir da qual se pode atribuir propriedade à noção de reserva. Além disso, nesse segmento, a expressão "Uma coisa que fosse substancialmente forte" (linha 39) permite relação pessoa e ato, isto é, os atributos da proposta podem ser associados ao agente, e vice-versa.

O orador segue nessa mesma direção, quando evidencia características dos agentes responsáveis pelo viés do domínio da família, como se apresenta no segmento (22): 
$[\ldots]$

Então, eu não queria dizer que tem um "fundo Lula", um "fundo Chirac", um "fundo Lagos", ou um "fundo Gordon Brown", ou seja, o nome não importa, a paternidade não importa, o que importa é que a gente assuma um compromisso de que, do dinheiro que circula no mundo, uma parcela pequena pode constituir um grande fundo para que a gente possa, definitivamente, sonhar que daqui a 30 ou 40 anos a gente terá um mundo mais justo, mais equânime e mais solidário. É esse o meu sonho, é esse o meu desejo e é por isso que estou tentando brigar.

$[\ldots]$

Na conclusão do pronunciamento, o criador da proposta é categorizado como pai. Esta classificação ativa alguns valores concretos, pertinentes do domínio da família (linhas 54-55), relacionados aos deveres do pai em relação aos seus filhos. Posteriormente, examinamos a construção da situação futura, que poderá ocorrer a partir da proposta de Lula: "um mundo mais justo, mais equânime e mais solidário. É esse o meu sonho, é esse o meu desejo" (linhas 58-59). A respeito destas seleções lexicais referenciais, entendemos que os encapsulamentos "esse o meu sonho" e "esse o meu desejo" correspondem a estratégias de construção de uma imagem de si como pai benfeitor, que assume os valores da família global. Por serem apresentadas no encerramento do discurso, tais seleções permitem que o auditório relacione os valores utilizados ao ex-presidente e reconheça coerência entre o que foi dito e quem disse.

\subsubsection{9 ${ }^{\mathrm{a}}$ Assembleia-Geral da ONU (Nova Iorque, 2004)}

Em nossa discussão teórica, vimos que, no governo do ex-presidente da República Luis Inácio Lula da Silva, as relações internacionais passaram por algumas transformações, tanto em questões voltadas ao papel do Estado brasileiro no exterior, quanto à participação dos países subdesenvolvidos no campo internacional. Segundo Oliveira (2005), a diplomacia brasileira passou a considerar o multilateralismo como estratégia de desconcentração e de aplicação de novas regulamentações da política internacional. Desta maneira, os discursos pronunciados pelo ex-presidente, entre chefes de Estado e de governo, caracterizam-se, principalmente, por promover mudanças nas relações internacionais, tais como a de buscar a reforma e a ampliação do Conselho de Segurança da ONU (CSNU) e, principalmente, a de incluir o Brasil como membro permanente desse grupo. Em relação a este último objetivo, 
pode-se dizer que a busca também é por fazer que o país se fortaleça mundialmente, como se afirma no site $e^{85}$ brasileiro do CSNU:

O ingresso do Brasil como membro permanente reforçaria, ademais, a capacidade do país de influir em decisões de alcance global segundo os princípios que defende e que regem sua política externa e que correspondem, em grande medida, àqueles igualmente defendidos por uma ampla maioria dos demais países em desenvolvimento.

Esse órgão das Nações Unidas, o CSNU, tem por funções, entre outras, assegurar a paz mundial, promover melhores padrões de vida e direitos humanos. Ele é composto por quinze membros, sendo que dez são rotativos com mandatos de dois anos - em 2004, compunham esse grupo: Alemanha, Angola, Argélia, Benin, Brasil, Chile, Espanha, Filipinas, Paquistão e Romênia - e cinco permanentes com direito de voto - Estados Unidos da América, Rússia, China, França e Reino Unido.

Levando-se em conta tais especificidades, selecionamos um discurso do ex-presidente Luis Inácio Lula da Silva na $59^{\mathrm{a}}$ Assembleia Geral da ONU, proferido em vinte e um de setembro de 2004, em Nova Iorque. O chefe do Estado brasileiro costuma ser o primeiro a se pronunciar nesses encontros. Assim também ocorreu com o ex-presidente da República Lula, que se apresentou no início das Assembleias, em quase todos os anos de seu mandato, exceto, em 2005 e em 2010, quando ele foi representado pelo então ministro das relações exteriores, Celso Amorim.

Julgamos significativo ressaltar um segmento do início do discurso do ex-presidente, na ONU, em 2004:

Pela segunda vez, dirijo-me a esta assembléia universal para trazer a palavra do Brasil. Carrego um compromisso de vida com os silenciados pela desigualdade, a 15 fome e a desesperança. A eles, nas palavras tremendas de Franz Fanon, o passado colonial destinou uma herança comum: 'Se queres, aí a tens: a liberdade para morrer de fome'.

\footnotetext{
${ }^{85}$ Disponível em: http://www.brasil-cs-onu.com/brasil-no-conselho-de-seguranca-da-onu/. Acesso em 13 maio 2013.
} 
Em (23), podemos constatar que os objetos de discurso selecionados "a palavra do Brasil” (linhas 13-14) e "os silenciados pela desigualdade, a fome e a desesperança" (linhas 14-15) já revelam os papeis assumidos, no e pelo discurso, por Lula: representante dos brasileiros no exterior e defensor das pessoas que vivem em situação de miséria e não podem se pronunciar.

Em relação à formulação "os silenciados pela desigualdade, a fome e a desesperança" (linhas 14-15), retomemos os estudos de Lakoff e Johnson (1980), de Kövecses (2005) e de Charteris-Black (2004, 2011), discutidos às páginas 35-37 deste trabalho. Os estudiosos afirmam que metáforas podem indicar os valores assumidos pelo enunciador e revelar como ele compreende dada realidade empírica, conforme a maneira de se referir a ela discursivometaforicamente. Em consonância com esta afirmação, entendemos haver pistas dos valores que serão defendidos pelo orador no exórdio deste corpus, por meio das seleções lexicais destacadas.

Ainda em relação ao segmento (23), as palavras de Franz Fanon são rotuladas como "uma herança comum" (linha 16). Este rótulo metadiscursivo também corresponde a um elemento indicativo do ponto de vista do orador: "os silenciados pela desigualdade, a fome e a desesperança" têm destino certo dado por aqueles que, na história, detiveram o poder econômico: o de morrer de fome. Ao mesmo tempo, entende-se que se inicia a argumentação, voltada para a emoção.

O orador segue, em seu pronunciamento, selecionando termos metafóricos, entre outros, de modo a conduzir um olhar a respeito da situação de injustiça social. É a partir dos seguintes procedimentos que Lula vai delineando um cenário discursivo:

(24)

Hoje somos 191 Estados-nação. No passado, 125 deles foram submetidos ao jugo de umas poucas potências que originalmente ocupavam menos de $2 \%$ do globo. $\mathrm{O}$

20 fim do colonialismo afirmou, na esfera política, o direito dos povos à autodeterminação. [...]

[...]

Em 1820, a diferença de renda per capita entre o país mais rico e o mais pobre do

25 planeta era inferior a cinco vezes. Hoje, essa diferença é de 80 vezes. Os antigos súditos converteram-se em devedores perpétuos do sistema econômico internacional. 
Nos segmentos (24) e (25), os objetos de discurso situam-se em tempos diferentes no discurso, dando a conhecer uma ação contínua e inadequada em termos de valores abstratos, como o de liberdade (“o jugo", à linha 18). Neste viés, são apresentados os responsáveis pela situação de desigualdade - "umas poucas potências" (linha 19), "Os antigos súditos" (linhas 25-26), "devedores perpétuos do sistema econômico internacional” (linhas 26-27)- de tal modo que se chega à avaliação de a dívida ser vitalícia.

Na sequência, como se pode observar, em (26), o procedimento continua recaindo sobre a ideia da falta de liberdade do comércio internacional. É pela metáfora ontológica, de coisificação, que se vão constituindo objetos de discurso, pelos quais são questionados os direitos e os deveres dos países na relação econômica global:

$[\ldots]$

Barreiras protecionistas e outros obstáculos ao equilíbrio comercial, agravados pela concentração dos investimentos do conhecimento e da tecnologia, sucederam ao domínio colonial. Poderosa e onipresente, uma engrenagem invisível comanda à distância o novo sistema. Não raro, ela revoga decisões democráticas, desidrata a soberania dos Estados, sobrepõe-se a governos eleitos, e exige a renúncia a legítimos projetos de desenvolvimento nacional. Manteve-se a lógica que drena o mundo da escassez para irrigar o do privilégio.

A formulação "Barreiras protecionistas e outros obstáculos ao equilíbrio comercial" (linha 27) - seleção de um hipônimo metafórico, reativado pelo seu hiperônimo - leva à presença do auditório a noção de obstáculos, resultantes de atitudes individuais (protecionistas), cujo objetivo consiste de proteger, em específico, o comércio interno de um número reduzido de países. Em seguida, associa-se o domínio da economia internacional ao da mecânica, de maneira a criar uma imagem específica do funcionamento do comércio global em vigência.

Assim, "Poderosa e onipresente, uma engrenagem invisível" (linha 29) pode ser entendida, quando associada indiretamente, como se tratando das barreiras protecionistas e, portanto, dos que comandam a economia global (“devedores perpétuos” etc.). Isto porque a análise desses segmentos, (24), (25), (26), indica-nos o favorecimento dado à tese de que os países, detentores do poder econômico, procedem a atitudes, cujos resultados levam à concentração do comércio. Nesta acepção, muito embora se defenda a mudança, existem forças que a impedem. 
O orador avalia a conduta e o funcionamento desse sistema por meio da seleção "a lógica que drena o mundo da escassez para irrigar o do privilégio”. Este procedimento carrega consigo valores negativos, pois se sugere que alguns são favorecidos em detrimento de outros. Neste processo discursivo, logo, tem-se a utilização de metáforas (ECONOMIA MUNDIAL É UMA MÁQUINA, ECONOMIA MUNDIAL É UM SISTEMA DE DRENAGEM, ECONOMIA MUNDIAL É UM SISTEMA DE IRRIGAÇÃO), as quais promovem um jogo referencial, que, ao mesmo tempo, estrutura um específico cenário discursivo de desigualdade e é estruturado por ele. Além do mais, a inter-relação dessas metáforas tem o papel de fortalecer a tese que está sendo apresentada no pronunciamento.

É justamente na atitude de privilegiar algumas características de um domínio-fonte, ou de vários, e associá-las a um objeto em foco que a metáfora fornece subsídios para que o auditório compreenda a representação que se quer dar a um estado de coisas. Mais do que isto, localmente situadas, metáforas inter-relacionam-se e criam uma orientação de caráter avaliativo. No caso do discurso proferido na ONU, as etapas do processo discursivo levamnos, como assim já afirmamos, a depreender um mundo desigual, em termos econômicos, políticos e sociais, e a falta de liberdade para fazer negócios.

Nesse viés, temos que "o país mais rico e o mais pobre” (linha 24), “os antigos súditos [...] devedores perpétuos do sistema econômico internacional" (linhas 25-27), "o mundo da escassez e o mundo do privilégio" (linhas 32-33), "países em desenvolvimento" (linha 102), "países desenvolvidos" (linha 140) correspondem a seleções referencias que reiteram, continuamente, pela lógica dos contêineres, a noção de seres humanos situados em espaços distintos. Por se tratar de um discurso dirigido a líderes políticos na ONU, tal encaminhamento pode ser compreendido como uma crítica velada àqueles, cujas condutas não estão de acordo com os direitos humanos.

Interessa-nos, sobretudo, retomar a primeira parte do preâmbulo da Carta dos Direitos Humanos da Organização das Nações Unidas:

Considerando que o reconhecimento da dignidade inerente a todos os membros da família humana e de seus direitos iguais e inalienáveis é o fundamento da liberdade, da justiça e da paz no mundo,

Considerando que o desprezo e o desrespeito pelos direitos humanos resultaram em atos bárbaros que ultrajaram a consciência da Humanidade e que o advento de um mundo em que os todos gozem de liberdade de palavra, de crença e da liberdade de viverem a salvo do 
temor e da necessidade foi proclamado como a mais alta aspiração do ser humano comum,

Considerando ser essencial que os direitos humanos sejam protegidos pelo império da lei, para que o ser humano não seja compelido, como último recurso, à rebelião contra a tirania e a opressão,

Considerando ser essencial promover o desenvolvimento de relações amistosas entre as nações,

Considerando que os povos das Nações Unidas reafirmaram, na Carta da ONU, sua fé nos direitos humanos fundamentais, na dignidade e no valor do ser humano e na igualdade de direitos entre homens e mulheres, e que decidiram promover o progresso social e melhores condições de vida em uma liberdade mais ampla, $[. .$.

Pode-se entender que o encaminhamento dado no discurso remete às declarações dos direitos humanos - e, consecutivamente, à Carta Internacional de Direitos Humanos - e que a base axiológica selecionada no pronunciamento trata-se dos valores assumidos na citação evidenciada. Assim, se os participantes compartilham conhecimento sobre esses alicerces ideológicos, tenderão a reconhecer o procedimento discursivo que recai sobre a atitude inadequada daqueles que detêm o poder para mudar. Em consequência deste reconhecimento a partir do qual se chega a um raciocínio alinhado à tese, a argumentação voltada à necessidade de novas posturas pode ser convalidada.

Dessa maneira, tal diálogo é indicativo de uma estratégia argumentativa, principalmente se pensarmos no auditório em questão (ONU). Ocorre, então, uma adaptação do discurso ao público - fato que colabora com os propósitos argumentativos do orador. Tal estratégia já foi apontada por Aristóteles e, posteriormente, também por Perelman e Olbrechts-Tyteca como significativa para a argumentação (2002 [1958]).

Na sequência do pronunciamento, os responsáveis pela polarização (desigualdade) do mundo possibilitam a atuação de alguns agentes. A partir deste procedimento, a metáfora da guerra, articulada à ontológica, aparece e fortalece a tese de Lula. Observemos alguns segmentos desse discurso:

A falta de saneamento básico matou mais crianças na década passada do que todos os conflitos armados desde a Segunda Guerra. (linhas 40-41)

O ódio e a insensatez que se alastram pelo mundo nutrem-se dessa desesperança, da absoluta falta de horizontes para grande parte dos povos. (linhas 43-44) 
Esse processo, em que se orienta o auditório a agir para mudar um estado de coisas, fundamenta-se por metáforas, as quais tornam mais viável o reconhecimento de um recorte que se quer enfatizar, mas, por vezes, de modo que exima quem enuncia de alguma acusação. Isto ocorre em (27) e (28), uma vez que, pela metáfora ontológica, evidenciam-se as características da situação constituída discursivamente - “A falta de saneamento básico matou", "O ódio e a insensatez que se alastram [...] nutrem-se", entre outros - e, de modo consecutivo, indica-se que as diretrizes da carta da ONU não estão sendo seguidas.

É a partir da constituição da imagem do mundo como está (presente do discurso) que o orador prossegue, agora, apresentando sua proposta de mudança. Depreendemos que esta se configura pelo viés, principalmente, das metáforas da jornada e da construção/reforma. Juntos, estes domínios possibilitam o delineamento ora das ações (construção e reforma), ora de seus efeitos futuros (jornada). Observemos:

$[\ldots]$

O caminho da paz duradoura passa, necessariamente, por uma nova ordem

55 internacional, que garanta oportunidades reais de progresso econômico e social para todos os países. Exige, por isso mesmo, a reforma do modelo de desenvolvimento global e a existência de instituições internacionais efetivamente democráticas, baseadas no multilateralismo, no reconhecimento dos direitos e aspirações de todos os povos.

(30)

O que distingue civilização de barbárie é a arquitetura política que promove a mudança pacífica e faz avançar a economia e a vida social pelo consenso 80 democrático. Se fracassarmos contra a pobreza e a fome, o que mais poderá nos unir?

Há um jogo metafórico, por meio do qual a argumentação é desenvolvida. Ora motiva-se com o efeito futuro ("o caminho da paz duradoura", linha 54), ora propõe-se a mudança ("uma nova ordem internacional", linhas 54-55). E neste processo, ativam-se objetos de discurso que cumprem o papel de relembrar o auditório da falta de cumprimento de seus deveres:

Mais do que quaisquer estatísticas sobre a desigualdade social, o que deve 
60 interpelar nossas consciências é o olhar torturado dos que hoje estão do lado de fora da vida. São olhos que vigiam em nós o futuro da esperança. Não há mais destino isolado, nem conflito que não irradie uma dimensão global. Por mais que nos apontem o céu entre as grades, é preciso não confundir a gaiola de ferro com a liberdade. Temos conhecimento científico e escala produtiva para equacionar os desafios econômicos e sociais do planeta.

Sobre eles, interessa-nos, sobretudo, examinar as formulações, às linhas 60-61 - " $O$ olhar torturado dos que hoje estão do lado de fora da vida. São olhos que vigiam em nós o futuro da esperança; Por mais que nos apontem o céu entre as grades, é preciso não confundir a gaiola de ferro com a liberdade". Observamos que há um diálogo entre essas seleções e a quinta e a nona partes da Carta da ONU ("Ninguém será submetido à tortura nem a tratamento ou castigo cruel, desumano ou degradante"; "Ninguém será arbitrariamente preso, detido ou exilado"), favorecendo, mais uma vez, a argumentação, em razão de o embasamento recair sobre o sistema de crenças e de valores, a partir do qual se formou o grupo, e de trazer em foco outros recortes do objeto examinado no exórdio, às linhas 14-15 ("os silenciados pela desigualdade, a fome e a desesperança").

Além do mais, pode-se depreender a analogia apresentada por meio do termo "é preciso não confundir a gaiola de ferro com a liberdade" (linhas 63-64). De Marx Weber, a gaiola de ferro, ou jaula de ferro, foi uma metáfora utilizada para representar o sistema capitalista atual, em específico a organização burocrática, no sentido de afirmar que há um sistema que comanda vidas.

Assim é que "gaiola de ferro" orienta a ilusão existente da liberdade. Embora exista um sistema que aprisiona, que não permite o ajustamento de novas posturas, isto não ocorre de maneira clara, fazendo que haja possibilidade de se confundir. Do mesmo modo, pudemos examinar que se destaca a invisibilidade das "grades", existentes no sistema econômico em (31), quando o orador avalia a lógica desse processo ("a lógica que drena o mundo da escassez para irrigar o do privilégio", linhas 32-33). A dificuldade de mudar, construir "uma ordem mais justa e mais democrática", está justamente na noção ativada por "engrenagem invisível" (linha 29) e por "gaiola de ferro" (linha 63). Desta maneira, podemos afirmar que o procedimento discursivo em questão constituiu-se de categorizações, que permitem uma nova maneira de olhar a situação em questão e que privilegiam os valores marxistas, ou mesmo, do Partido dos Trabalhadores (PT). 


\subsubsection{O Combate à Pobreza (China, 2004)}

A primeira visita feita por Lula à China, como chefe do Estado brasileiro, ocorreu em maio de 2004. Conforme indicamos à página 91 deste trabalho, o ex-presidente da República foi acompanhado de uma comitiva de ministros e de governadores e quatrocentos empresários. O supertópico do encontro foi a pobreza, e discutiu-se, especificamente, sobre “O combate à pobreza". Nessa mesma visita, ocorreram outros encontros, nos quais os líderes debateram a respeito da parceria Brasil-China.

Tais informações da situação interacional em que houve o pronunciamento - mais especificamente, o fato de estarem presentes vários empresários - evidencia que existiram interesses também econômicos em jogo, mesmo que se tenha evidenciado, no título, um processo (combate) voltado, exclusivamente, à questão da pobreza.

Levando em conta tal especificidade, dando continuidade à análise do pronunciamento de Lula, salientamos que boa parte de seu discurso volta-se às atitudes do governo brasileiro em benefício dos mais pobres. Observemos o exórdio:

$[\ldots]$

20 É para mim motivo de grande satisfação estar em Xangai, no contexto de minha primeira visita à China como presidente do Brasil.

Fico especialmente feliz em poder participar, nesta bela e dinâmica cidade, de conferência sobre tema que é caro ao Brasil e a mim pessoalmente.

O combate à fome e à pobreza sempre esteve no centro de minhas atenções e é

25 hoje um tema central para o governo, tanto em sua ação interna, como externa.

Sei o que é a fome e sei o que é a pobreza.

Nas formulações destacadas, às linhas 23-24 (anexo 04), o orador relaciona sua própria imagem ao tópico do encontro, indicando uma história de vida caracterizada também pela pobreza e, consecutivamente, produzindo efeito de ser conhecedor do tópico. Entendemos que este procedimento evidencia uma atitude de autopromoção - por ser selecionada logo no exórdio do discurso - de modo a permitir que haja inter-relação governante-governo-Estado em um viés humanístico. Além do mais, a metáfora da guerra - "O combate à fome, à pobreza" (linha 24) - permite que se construa imagem de força a respeito, principalmente, de quem profere e assume o discurso. 
Observamos ainda - na formulação "O combate à fome e à pobreza sempre esteve no centro de minhas atenções e é hoje um tema central para o governo, tanto em sua ação interna, como externa" (linhas 24-25) - que há a noção de centro. A este respeito, é possível dizer que este corresponde ao lugar em que está o orador, haja vista que o corpo humano orienta tal noção. Neste viés, pode-se entender que é o espaço a partir do qual Lula olha, ele se posiciona. As seleções "central" e "centro" reforçam essa ideia de o orador aproximar sua imagem ao tópico pobreza. Assim é que se estrutura a metáfora da guerra (combate) pela metáfora orientacional, dando a conhecer o posicionamento de quem profere o discurso.

Após o primeiro contato entre orador e auditório pelo discurso, observamos que boa parte do pronunciamento volta-se aos programas sociais do governo de Lula e, assim, entendemos que o investimento continua recaindo sobre a busca por legitimação. O que ocorre é que, mais uma vez, o auditório é orientado a ver as atitudes governamentais como promissoras. Isto permite fazer que os participantes presentes sejam direcionados e fiquem predispostos a confiar no orador e a se tornarem sensíveis a aderir à proposta de âmbito global, apresentada, posteriormente, em outra etapa do discurso. É sobre ela que nos debruçamos a seguir:

(33)

60 Mas há também muito o quê fazer no plano externo, notadamente em prol dos esforços internacionais de combate à fome e à pobreza.

É preciso promover a expansão do mercado mundial para os produtos de países em desenvolvimento e favorecer um comércio internacional livre, equilibrado e capaz de oferecer oportunidades de distribuição da riqueza a todos que dele participam.

Em (33), na seleção "dos esforços internacionais de combate à fome e à pobreza" (linhas 60-61), o domínio conceptual, correspondente à guerra, aparece novamente, agora, de modo a redirecionar o discurso para a questão central do encontro. Outras formulações reiteram essa noção e são reforçadas por redes referenciais, nas quais estão presentes metáforas ontológicas. Passemos a seu exame na sequência em que foram apresentadas:

Já se pode antever a grandeza desse precedente e sua importância na luta contra $o s$ obstáculos que se erguem ao desenvolvimento econômico e social de dois terços da humanidade. (indicação das forças contrárias) 
(35)

Em fins de junho, irei à Nova York para falar ao Global Compact, instituição que congrega grupo seleto de empresas socialmente responsáveis.

Lá reiterarei meu apelo para que cada um cumpra o seu papel no combate à fome e à pobreza. (indicação dos agentes)

130 milhões de pessoas a cada ano. (indicação da arma de combate)

$\mathrm{O}$ combate à fome e à pobreza e a promoção do desenvolvimento são o caminho sustentável e verdadeiro para a paz mundial. (indicação dos agentes)

(38)

Esta Conferência em Xangai e eventos relacionados ao tema da pobreza compõem uma teia de oportunidades para que a revisão, em meados de 2005, da 145 implementação das Metas de Desenvolvimento do Milênio aponte soluções concretas e factíveis ao principal desafio de nossos dias: o combate à fome e à pobreza. (indicação dos agentes)

Mais do que categorizar e recategorizar a fome, a pobreza, as forças contrárias a partir das metáforas ontológicas de coisificação e de personificação, em que está subjacente a lógica do contêiner, ocorre um jogo de estratégias, no qual combate e percurso inter-relacionam-se, de maneira a permitir que se visualize o cenário discursivo no qual a proposta de mudança, "um plano de ação para a superação da fome e da pobreza" (linha 98), vai sendo delineada e relacionada às Metas de Desenvolvimento do Milênio as quais devem ser alcançadas até 2015. São elas: a diminuição da pobreza e da fome, a promoção da educação, da igualdade de gênero e de políticas de saúde, a melhoria em relação ao saneamento, à habitação e ao meio ambiente. Observemos os segmentos a seguir:

(39)

Já se pode antever a grandeza desse precedente e sua importância na luta contra $o s$ obstáculos que se erguem ao desenvolvimento econômico e social de dois terços da humanidade. (obstáculos do percurso)

(40)

Queremos encontrar meios de levar adiante compromissos assumidos, mas nunca cumpridos. (ação, percurso)

$\mathrm{O}$ combate à fome e à pobreza e a promoção do desenvolvimento são $o$ caminho sustentável e verdadeiro para a paz mundial. (direção, percurso) 
Além disso, ao propor uma mudança de postura política, o orador apresenta os possíveis resultados (efeito futuro) dessa nova atitude também pelo viés da metáfora do percurso. Efeito desta ordem pode ser examinado na formulação "avançar em direção a um mundo de prosperidade e equidade" (linhas 141-142), em que se evidencia o possível alcance do valor de igualdade. Observemos o segmento (42):

Proponho uma mudança de atitude, uma genuína parceria global. Ousemos criar um novo modelo de desenvolvimento, capaz de gerar melhores 140 condições de vida para os mais vulneráveis.

Não se trata de uma utopia. Juntos, podemos avançar em direção a um mundo de prosperidade e equidade.

Nessa etapa do discurso, a metáfora do percurso viabiliza a orientação do efeito futuro da mudança de postura. Em (39), (40), (41) e (42), trata-se de motivação retórica/argumentativa, pela qual o auditório é conduzido a ver a sua frente o processo político (“o caminho sustentável e verdadeiro", linha 132), os obstáculos (“os obstáculos que se erguem", linha 74) e os resultados positivos (“um mundo de prosperidade e equidade", linhas 141-142, "a paz mundial”, linha 132).

É nessa direção que discurso e metáfora operam no processo de referenciação e consistem de ações estratégicas, argumentativas. A busca por convencimento e por persuasão, levando em conta a perspectiva de Perelman e Olbrecths-Tyteca (2002 [1958]), discutida em nosso trabalho, é demarcada por meio da seleção e da inter-relação das metáforas do combate e do percurso, pelo fato de estas serem utilizadas para a menção de processos e de resultados.

Tem-se, pois, uma argumentação política conduzida pelo viés da cooperação, em que as causas, os efeitos e as consequências evidenciados orientam determinadas sanções. À página 142, ainda em consonância com os estudos de Perelman e Olbrecths-Tyteca (2002 [1958]), relacionamos uma das noções de ligação por coexistência, a da consequência, às especificidades dos encontros entre líderes de Estado e de governo. Entendemos que existe a necessidade de um Estado, por meio de seus governantes, alcançar imagem de coerência e de prestígio no campo internacional e indicamos a possibilidade de se recorrer à visualização das consequências favoráveis e desfavoráveis de uma ação, para que o julgamento dos atos seja orientado de determinado modo. No caso do pronunciamento de Lula, a metáfora do percurso 
estrutura a ideia de um resultado positivo, por estar implicada a ideia de justiça social. Os comportamentos sugeridos, ligados ao domínio de guerra, também são justificados a partir da visualização de suas consequências.

Nesse viés, enquanto essa formulação destacada em (42) - "podemos avançar em direção a um mundo de prosperidade e equidade" (linhas 141-142) - reforça a noção de efeito futuro de sociedade ideal por meio da metáfora do percurso, o efeito de força para agir pode ser suscitado pelo domínio-fonte da guerra, o qual também direciona certas categorizações dos inimigos, dos aliados e das vítimas na rede referencial do pronunciamento. Vejamos estes dois últimos:

(43) Categoria: vítimas da guerra

Subcategorias: dois terços da humanidade (linhas 74-75); milhões de pessoas (linhas 130-131); os pobres do mundo (linha 165).

(44) Categoria: aliados da guerra

Subcategorias: todos os chefes de Estado e de governo (linha 147); cada um [líderes políticos] (linha 124); Todos os governantes do mundo, dos mais ricos até os mais pobres (164-165).

Embora tais formulações não apresentem explicitamente sentido metafórico, este se dá no cotexto, por elas fazerem parte de uma das metáforas centrais selecionadas, a de guerra. A respeito disto, retomemos nossa discussão apresentada no capítulo 1 deste trabalho (p. 68-69), quando afirmamos, primeiramente, a respeito das anáforas indiretas, conforme os pressupostos de Koch (2008a), ressaltando que algumas dessas expressões anafóricas ligam-se no discurso por meio de um processo de associação, no qual, por vezes, é necessário ativar um conhecimento conceptual mais geral para sua interpretação. Nesta direção, a metáfora da guerra ativada possibilita que se associem algumas formulações com função referencial como "dois terços da humanidade (linhas 74-75); milhões de pessoas (linhas 129-130); os mais vulneráveis (linha 140); os pobres do mundo" (linha 165) - de modo a se chegar a uma categoria específica (por exemplo, as vítimas).

Assim é que os dados contextuais (quem fala, para quem se fala, o tópico etc.) e os contextuais (ativação e inter-relação de metáforas estruturais) dão o entorno necessário para que se criem certas âncoras cognitivas, essenciais para a compreensão do discurso. No caso 
do pronunciamento sob análise, o modelo mental de guerra compartilhado possibilita inferências, pelas quais o auditório pode entender certas redes referenciais de modo metafórico (vítimas, aliados, inimigos etc.). É neste viés que a metáfora dialoga com as especificidades da interação e com a organização do discurso; seu uso é sempre atualizado, assim como afirmamos às páginas 45-46 deste trabalho.

Os valores do domínio-fonte "guerra" estão imbricados nas redes referenciais, constituídas a partir dele. Mais do que isto, tais valores somam-se às informações postas nas expressões nominais referenciais. Pode-se dizer que, quando se procede a indicar as vítimas, atribuem-se a elas outras características a partir do modo em que são construídas no discurso, tal como a questão de serem numerosas - "dois terços da humanidade" (linhas 74-75); "milhões de pessoas" (linhas 129-130). Entendemos que o procedimento de dizer sobre os números das vítimas reforça a ideia da necessidade de parcerias para resolver a situação.

Por fim, ainda julgamos significativo salientar que o orador encerra seu pronunciamento, ativando, explicitamente, os valores correspondentes aos direitos humanos:

(45)

O ser humano pode ficar sem muitas coisas na vida, mas tem direitos elementares que estão na Bíblia, que estão em todas as Constituições e que estão na 170 Declaração Universal dos Direitos Humanos: todos têm direito a tomar café, almoçar e jantar todo dia. Esse é o direito mais elementar, portanto deve ser a obrigação mais elementar para que cada governante do mundo permita que seu povo tenha acesso a esses bens mínimos que a humanidade tanto precisa.

Boa sorte e, se Deus quiser, nós cumpriremos as metas do milênio.

Muito obrigado.

As seleções apresentadas, ao término do pronunciamento, são pistas dos valores privilegiados, os quais devem ser seguidos por "cada governante do mundo" (linha 172). Tem-se que campos de atuação diversos ligam-se por um fator em comum: os direitos humanos. Assim, a rede referencial destacada em (45), "direitos elementares que estão na Bíblia, que estão em todas as Constituições e que estão na Declaração Universal dos Direitos Humanos (cf. anexo 11); Esse é o direito mais elementar; a esses bens mínimos que a humanidade tanto precisa", serve como engajamento argumentativo pelo qual a argumentação é direcionada a auditórios particulares - "bíblia" (religioso), "Constituição" (regras internas dos países), "Declaração Universal dos Direitos Humanos” (política global) trazendo força à tese a partir de um posicionamento convalidado por valores da maioria. 
A partir desses procedimentos, pode-se chegar à comunhão, ao que é comum em termos de responsabilidades dos líderes. Nesta direção, evidenciar interesses comuns consiste de um modo de fazer que um auditório em específico reconheça um determinado país como membro de seu grupo, promovendo aproximação entre partes e, assim, aceite cooperação de diversas ordens.

\subsection{Metáfora e processo de referenciação nas negociações bilaterais e multilaterais: relação entre o eu e o(s) outro(s)}

\subsubsection{Brasil e Portugal}

\subsubsection{Cerimônia de Chegada a Portugal (2003)}

Em dez de julho de 2003, em Lisboa, o ex-presidente da República Luís Inácio Lula da Silva pronuncia um discurso de cerimônia de chegada a Portugal. Examinamos que foi dada ênfase à relação entre os países (Brasil e Portugal). A este respeito, depreendemos a metáfora RELAÇÃO BILATERAL É VIAGEM MARÍTIMA A DOIS, em que a questão histórica é utilizada como eixo principal, norteador do que é comum entre partes, do que as une.

No início do pronunciamento, formulações referenciais especificam os passageiros da viagem - Portugal e Brasil - o lugar do encontro e a rota em comum. Observemos os segmentos destacados:

05 Agradeço as gentis palavras de boas-vindas do presidente Jorge Sampaio e a presença de tantos e fraternos amigos aqui reunidos.

É uma grande satisfação estar em Portugal. Venho para renovar e aprofundar o excelente diálogo existente entre nossos países.

O simbolismo deste local é incomparável. Não existe outro lugar que marque de

10 forma tão acentuada o cruzamento de nossos destinos como a Torre de Belém. Daqui partiram as caravelas e os grandes navegadores, que estão na origem do nosso país.

Nos reencontramos hoje para celebrar 503 anos dessa rota comum, que cada vez mais se enriquece e diversifica. 
É na primeira parte da argumentação - no exórdio - que se procede a evidenciar o que é comum entre ambos os países. Nesta acepção, entendemos haver a busca por comunhão e confiança. Na referenciação, fazer alusão a um fator histórico - "as caravelas e os grandes navegadores, que estão na origem do nosso país" (linhas 11-12) - e a amizade existente entre Brasil e Portugal - "tantos e fraternos amigos" (linha 06) - propicia que se reconheça a existência de um elo e que se produza efeito de afinidade. Compreendemos que tal procedimento corresponde à estratégia argumentativa apresentada por Perelman e OlbrecthsTyteca (2002 [1958], p.561), relacionada à conduta de motivar o auditório a agir a partir da relação específica criada entre os participantes logo no início do processo discursivo.

Temos ainda o pressuposto de Charteris-Black (2007), indicado à página 138 deste trabalho, a respeito de o líder político fazer uso de símbolos e de metáforas, para conectar pontos de vista específicos e criar imagens de realidades social e política a partir de um viés argumentativo. Assim também, esse estudioso e os autores da Nova Retórica, Perelman e Olbrechts-Tyteca (2002 [1958]) discorrem sobre a possibilidade de o orador buscar respostas emotivas por meio da seleção de ligações simbólicas, em razão de estas poderem despertar certos sentimentos, como o de nações unidas por um fator comum, tal como entendemos ocorrer no pronunciamento sob análise.

Nessa direção, a formulação referencial “a Torre de Belém” (linha 10), um dos monumentos mais importantes de Lisboa, símbolo de nacionalismo, classificada como patrimônio mundial pela UNESCO e uma das sete maravilhas de Portugal, favorece que se suscitem determinados sentimentos patrióticos e que se relacione tais emoções à imagem do Brasil, pelo fato de esse símbolo também ser correlacionado ao ponto de partida das caravelas portuguesas, à época das navegações.

A ativação desses conhecimentos permite que se visualize a noção de viagem, mais especificamente, a de navio. Procede-se à busca por aproximação de espaços, geograficamente, distantes. No momento em que são apresentadas no discurso, tais informações históricas, inseridas no domínio da viagem, constituem-se em conhecimentos prévios, pelos quais se orientam efeitos de sentido singulares aos objetos de discurso Brasil e Portugal. O que é preferível em termos de modelo mental se torna evidente, quando examinamos o entrelace existente entre as imagens dos países-passageiros e do caminho, a partir do qual eles prosseguem juntos: "outro lugar que marque de forma tão acentuada o cruzamento de nossos destinos" (linhas 09-10), "dessa rota comum, que cada vez mais se enriquece e diversifica" (linhas 13-14). 
Assim, depreende-se que se conhece e valoriza-se o caminho feito pelos países historicamente. Nesta mesma acepção, na próxima etapa do discurso, que consideramos ser a narração de uma viagem em decurso, o orador continua a conceptualizar a relação Brasil e Portugal. Examinemos que a viagem marítima se torna evidente por meio da seleção "Brasil e Portugal estão embarcados" e se destaca a proposta de ação política, inserida no percurso da viagem, a partir de um diálogo entre metáforas estruturais, a de viagem e a de construção:

Nossos caminhos continuam hoje a fertilizar-se, graças aos vínculos históricos, ao 15 importante intercâmbio econômico-comercial bilateral e à ação diplomática de nossos governos.

Brasil e Portugal estão embarcados em um novo desafio: a construção de um espaço comum, onde a identidade lingüística e cultural se transforma em realidade política na cena internacional.

As metáforas estruturais - viagem e construção - viabilizam a constituição de um específico cenário discursivo e estruturam a rede referencial desse segmento. Aliadas às orientacionais e às ontológicas (espacialização, personificação, coisificação), elas criam condições para que o auditório compreenda o cenário construído e a proposta enunciada, por meio da atitude de transformar em algo concreto o que, a princípio, é abstrato: terra fértil, Estados-agentes (passageiros) e a ideia de mudar a política internacional em termos de construir espaço comum. Isto se dá, principalmente, no modo acentuado de trazer à presença do auditório os laços existentes por meio de seleções lexicais metafóricas. Neste viés, é que a referenciação viabiliza orientação argumentativa, a partir da apresentação do que se tem como comum.

\subsubsection{Oportunidades de Novos Negócios e Investimentos Brasil-Portugal (2005)}

No capitulo 3 deste trabalho, às páginas 151-152, observamos, brevemente, um segmento do pronunciamento de Lula em Portugal, realizado em treze de outubro de 2005. Em específico, identificamos a metáfora PARCERIA BILATERAL É JORNADA A DOIS. Neste momento, nosso exame recai sobre o percurso utilizado para reforçar esse conceito. Retomemos parte do exórdio do discurso: 
(48)

Estou convencido de que as perspectivas para as nossas relações econômicas e comerciais nunca foram tão favoráveis. Sei que nossos parceiros portugueses estão bem informados sobre o Brasil. Somos, hoje, o segundo principal destino dos investimentos de portugueses. Brasil.

Interessa-nos, ainda, retomar a discussão apresentada no capítulo 2 (p.105) a respeito de as relações bilaterais fazerem parte das metas das visitas presidenciais, nas quais se busca estabelecer força política e econômica tanto no contexto internacional como no interno de um país. Neste viés, um presidente da República, no e pelos seus pronunciamentos, busca alcançar alianças e promover a imagem positiva de seu país e do governo. Por tal razão, criar condições para que os interlocutores cheguem a lugares comuns pode ser uma maneira de conseguir o convencimento e a persuasão almejados.

A partir desses pressupostos, observamos que, no segmento (48), o ex-presidente apresenta as perspectivas positivas (efeitos futuros) da relação Brasil-Portugal, e constrói o Brasil como destino de Portugal: "o segundo principal destino dos investimentos de portugueses" (linhas 33-34). Neste procedimento, a seleção da metáfora da jornada permite que se delineie a noção de movimento feito por dois agentes ("Brasil", linha 33, "nossos parceiros portugueses", linha 32), os quais ultrapassaram etapas ("nossas relações ultrapassaram a etapa dos discursos bem-intencionados", linhas 35-36) e se deparam com o que vem pela frente ("novas oportunidades de investimentos no Brasil", linhas 36-37).

A partir da metáfora RELAÇÃO BILATERAL É JORNADA A DOIS, existe a ideia de movimento de corpos (BRASIL É AGENTE EM MOVIMENTO, PORTUGAL É AGENTE EM MOVIMENTO) em uma determinada noção espaço-temporal com objetivos comuns. Além disto, como mencionamos à página 152, a relação do domínio-fonte jornada e domínio-alvo de processos políticos e de agentes propicia que os interlocutores construam as etapas e o final de certos comportamentos a partir de um viés axiológico, pelo qual a tese do discurso pode ser reforçada, tal como se pode examinar no segmento apresentado, em que a ação conjunta (Brasil e Portugal) é orientada como promissora.

É preciso unir e, para tanto, o investimento ajusta-se à noção de jornada de modo a possibilitar aproximação da imagem dos países, por meio do que é dito como comum: o caminho percorrido por ambos. Assim é que o pronunciamento revela-se como estratégia de 
correlação de imagens interestatais, evidenciando informações correspondentes às especificidades também históricas:

$[\ldots]$

Recorrendo a outro lugar comum, basta lembrar o exemplo dos exploradores e

105 comerciantes portugueses na época dos descobrimentos. Vasco da Gama e seus companheiros não inventaram sozinhos uma nova rota para a Índia. Não abriram mercados do nada. Após dobrar o Cabo da Boa Esperança, usaram o conhecimento dos navegadores e comerciantes árabes.

Essa forma de fazer negócios continua válida até hoje. Se Portugal e Brasil 110 conhecem os atalhos em suas respectivas regiões, devemos usar essa vantagem em nosso benefício.

Nesta visita, me acompanha uma importante delegação de empresários que estão dispostos a explorar esses atalhos.

$[\ldots]$

À página 78 do capítulo 2, apresentamos nosso pressuposto de que conduzir o outro a ver determinado objeto de discurso a partir de um viés e, assim, orientá-lo de modo argumentativo corresponde ao produto do entrelace entre conhecimentos velhos e novos. Estes são delineados no processamento discursivo e são associados às representações mentais partilhadas entre os interactantes. É possível examinar tal processo em (49), na medida em que a metáfora PARCERIA BILATERAL É JORNADA A DOIS é reforçada por meio da ativação de conhecimentos comuns recuperados (a história de Portugal e do Brasil), e a constituição de um novo ou de um conceito já existente é atualizado no pronunciamento (novas oportunidades de investimentos no Brasil). A noção da jornada feita pelos portugueses exploradores é encapsulada como "Essa forma de fazer negócios" (linha 109), possibilitando que se reconheça o lugar comum, assim como no próprio discurso se indica: "Recorrendo $a$ outro lugar comum" (linha 104). O processo referencial dá a conhecer o encaminhamento de sentido privilegiado que ainda é o de jornada: "Portugal e Brasil" (linha 109), "os atalhos" (linha 110), “essa vantagem” (linha 110), “uma importante delegação de empresários que estão dispostos a explorar esses atalhos" (linhas 112-113).

Interessa-nos salientar que a imagem do objeto de discurso Brasil é constituída por associações de categorias. Temos que, se por um lado a ideia é unir as imagens dos países, utilizando-se, de modo recorrente, as categorias ("Portugal e Brasil") junto ao conectivo "e" e a outras formulações que implicam a noção de "nós" ("as nossas relações", linha 31, "a nossa 
associação", linha 121), por outro, ocorre ativação da categoria dos empresários, os quais, por serem apresentados como exploradores, possibilitam que se ativem âncoras cognitivas associativas, que recuperam informações postas ("uma importante delegação de empresários que estão dispostos a explorar esses atalhos, Brasil e Portugal, as nossas relações econômicas e comerciais"), permitindo que se reconheçam os agentes da jornada de negócios.

Relacionamos tal observação à questão já mencionada sobre as categorias serem estruturadas pela lógica dos contêineres. Estes estão presentes no modo como se organizam os objetos de discurso, logo, viabilizam os processos referenciais, dando a conhecer a organização dada à realidade discursiva. Nesta acepção, examinamos que ocorre mais do que isto neste pronunciamento. A atitude de apresentar o que é comum, de unir países - os quais estão, geograficamente, separados - implica a busca por transformar modelos mentais de categorias relativamente estáveis, em um processo de sobreposição de categorias por meio da ativação de objetos de discurso unidos por uma associação cognitiva, na qual se evidencia o que é comum entre as partes. Há pistas linguísticas desse jogo de aproximação - "nossos antepassados" (linha 119), "a nossa associação" (linha 120), "um dos poetas da nossa Língua Portuguesa" (linhas 122-123) etc. - no seguinte segmento:

$[\ldots]$

A ousadia e o engenho de nossos antepassados serão sempre fonte de inspiração 120 para a nossa associação. Vencemos oceanos e unimos continentes e povos. Construiremos, agora, as pontes de uma nova cooperação, mais densa e madura. $\mathrm{O}$ vento é favorável e, como disse um dos poetas maiores da nossa língua portuguesa, "navegar é preciso".

Em um viés argumentativo, podemos afirmar que tais procedimentos correspondem às estratégias de ligações de solidariedade. Como mencionamos, em consonância com Perelman e Olbrechts-Tyteca (2002 [1958]), a argumentação, embasada a partir desse tipo de acordo, procura unir elementos diversos como partes indissociáveis. Este encaminhamento dá-se por meio da apresentação dos feitos de determinadas ligações, isto é, pela seleção de informações que evidenciam um vínculo causal, ou mesmo, o resultado de um acontecimento. Assim é que se assegura a ideia de compromisso a partir do efeito de um ato passado, responsável por um desdobramento favorável. Entendemos ser isto que ocorre no pronunciamento de Lula, na medida em que este orador recupera a ligação histórica existente entre Brasil e Portugal. 
Ainda em relação ao segmento (50), temos que a noção de parceria, estruturada pela metáfora PARCERIA BILATERAL É JORNADA A DOIS, vai sendo delineada a partir de outras informações. Observemos que as dificuldades físicas da jornada são tidas como superadas ("Vencemos oceanos e unimos continentes e povos", linha 120). Além do mais, metáforas estruturais (jornada e construção) entrelaçam-se nesta parte, encaminhando o sentido de ação futura dos agentes no processo de jornada: "Construiremos, agora, as pontes de uma nova cooperação, mais densa e madura" (linha 121). Nesta formulação, a metáfora PARCERIA BILATERAL É CONSTRUÇÃO A DOIS viabiliza o objeto de discurso "as pontes de uma nova cooperação, mais densa e madura”, constituído também por outra metáfora, que é a ontológica (coisificação). Por ela, é que se visualiza o resultado, a união entre os países, recuperando-se a ideia de atalho e o conceito de jornada.

Quando se dirige aos empresários portugueses, Lula constrói o Brasil como "uma grande oportunidade" (noção de tamanho viabilizado pela metáfora ontológica). Já ao se voltar para os empresários brasileiros, entendido como outro auditório particular, o orador segue a utilizar o conceito de jornada associado ao de parceria bilateral. O investimento recai sobre a necessidade de ação conjunta - E quero dizer aos empresários brasileiros: política e comércio exterior são uma via de duas mãos (linha 187) - delineada em todo processo discursivo:

[...]

185 Portanto, com essas palavras eu quero dizer aos empresários portugueses: o Brasil continua sendo uma grande oportunidade. E quero dizer aos empresários brasileiros: política e comércio exterior são uma via de duas mãos, a gente não pode querer apenas vender, a gente não pode querer apenas investimento no nosso país. É preciso que a gente também se disponha a comprar, e é preciso que a gente

190 também se disponha a investir. Essa combinação de compra e venda, dos dois lados, e de investimento, dos dois lados, pode ser a combinação perfeita que pode consolidar aquilo que os navegadores portugueses acreditavam quando descobriram o Brasil, de que era possível, apesar do Oceano Atlântico, unir essas duas Nações. Eles já fizeram a parte deles, agora cabe a nós darmos prosseguimento.

A ação conjunta indicada pela formulação "política e comércio exterior são uma via de duas mãos" (linha 187) - que se trata de uma definição pela qual se categoriza "política e comércio exterior" de modo metafórico - é reforçada por meio do encapsulamento "Essa combinação de compra e venda, dos dois lados, e de investimento, dos dois lados" (linhas 
190-191) e pela categorização "pode ser a combinação perfeita que pode consolidar aquilo que os navegadores portugueses acreditavam quando descobriram o Brasil, de que era possível, apesar do Oceano Atlântico, unir essas duas Nações” (linhas 191-194).

À página 67, discutimos, com Consten e Knees (2008), Koch (2008) entre outros, que, pelo encapsulamento, sumariza-se o segmento posto, tornando-o objeto de discurso, o qual poderá se apropriar de outras categorizações, conforme o encaminhamento dado pelo locutor. Neste processo de (re)categorização, avaliações são apresentadas e posições evidenciadas, tal como pudemos examinar em (51), quando a categorização metafórica "via de mão duas mãos" e outras formulações que a reforçam - "a gente não pode querer apenas vender, a gente não pode querer apenas investimento no nosso país. É preciso que a gente também se disponha a comprar, e é preciso que a gente também se disponha a investir" - são rotuladas como "Essa combinação [...]" (linha 190). Mais do que isto, retomam-se informações sobre o passado comum entre Brasil e Portugal, chegando à seguinte categorização a respeito desses países: “essas duas Nações” (linhas 193-194).

Como já postularam Perelman e Olbrechts-Tyteca (2002 [1958]), o que é apresentado ao auditório em termos de informações e de recortes consiste de um fator importantíssimo para a argumentação, em razão do efeito de presença que pode provocar. Tal procedimento torna possível que o orador aja diretamente sobre a percepção do outro. No caso deste pronunciamento, o olhar recai sobre a estreita relação existente entre Brasil e Portugal. Além disso, o procedimento de evidenciar o que é comum pode ser entendido como um posicionamento ideológico de construir a noção de nós, de um só grupo (Van Dijk, 2008). Os processos de referenciação delineiam esta visão específica sobre a relação existente entre os países e possibilita que se entenda haver coadunação de diversas ordens, tais como a de língua, de costume e de jornadas promissoras em comum, de agentes e de nações que, juntas, buscam poder na política internacional.

Nesse viés, observamos que processos referenciais específicos e atividades de categorização e recategorização, correspondentes ao Brasil, a Portugal e à parceria de ambos, inserem-se na noção de jornada e são constituídos a partir de várias formulações de modo associativo (anáforas associativas). 


\subsubsection{Brasil e Índia}

\subsubsection{Fórum Empresarial Brasil-Índia (Mumbai, 2004)}

Na agenda do governo do ex-presidente da República Luís Inácio Lula da Silva, vimos que o estabelecimento de parcerias com a Índia consistiu em um dos objetivos específicos de seus dois mandatos. O continente asiático foi visto como espaço promissor para as negociações políticas, nas quais foi contemplado o objetivo de aumentar a participação do Brasil no âmbito internacional.

Desse modo, alcançar respostas positivas de governos asiáticos, no que se refere a acordos comerciais, correspondeu às finalidades das visitas do ex-presidente Lula a esse continente. Nesta direção, a questão cultural, a distância geográfica e os objetivos específicos de cada governo dão contornos singulares aos discursos direcionados a cada auditório em termos de estratégias argumentativas. Isto porque a partir do momento em que se altera o é visto como comum entre os países, o direcionamento dado ao discurso muda - dando outras condições de interpretações que levem a espaços comuns. Nesta acepção, entendemos que se privilegia um encaminhamento cognitivo conforme as especificidades de cada auditório, em interações globais como essas.

No caso do pronunciamento apresentado na Índia, examinamos que o investimento recai sobre uma peculiar construção discursiva da situação econômica global. Mais especificamente, compreendemos que a necessidade de convencer e de persuadir os interlocutores a investirem em mercados brasileiros, vista como atitude nova, em face das negociações já existentes e tradicionais na política internacional, leva o governo brasileiro, no e pelo discurso, a encaminhar a ideia de um mundo novo, promissor de posturas inovadoras.

Levando em consideração tais pressupostos, tratamos de examinar a seleção de metáforas, que dão sentidos específicos nesse pronunciamento, ao serem apresentadas em sua materialidade linguística, evidenciando seu papel referenciador e argumentativo. Depreendemos que o domínio dos negócios é ativado e associado ao do garimpo, de modo a resultar no conceito O MUNDO GLOBAL DE NEGÓCIOS É UM GRANDE GARIMPO.

Salientamos que essa estratégia de se utilizar conhecimentos específicos do domínio dos negócios, no qual há estruturas convencionalizadas e reconhecidas pelos participantes (governos, empresários), aparece em um momento oportuno no discurso: após o orador ter ativado e delineado uma imagem positiva e valorizadora da Índia, a partir de um objeto de 
discurso que recupera um símbolo histórico desse país, que é o monumento Taj Mahal. Observemos como o pronunciamento é encaminhado e a argumentação conduzida:

20 Eu tinha preparado um discurso razoavelmente longo para proferir hoje aos empresários brasileiros e aos empresários da Índia. Porém, o importante é que eu diga a vocês a impressão com que volto para o Brasil, depois desses poucos dias visitando a Índia, com um grupo respeitável de empresários brasileiros, que estão buscando parceiros e sócios para os seus investimentos, tanto aqui como no Brasil.

40 Quero agradecer o espetáculo de beleza que a Índia me proporcionou hoje quando, por meia hora, eu pude visitar aquele monumento em homenagem à humanidade, o Taj Mahal. Realmente, eu acho que um país que consegue preservar um monumento daquela magnitude tem tudo para ser um país muito mais desenvolvido do que é atualmente.

O objeto de discurso "o espetáculo de beleza que a Índia me proporcionou” (linha 40), e a relação efetivada com o "aquele monumento em homenagem à humanidade" (linha 41), o “Taj Mahal” (linhas 41-42), "um monumento daquela magnitude" (linha 42-43) consistem em procedimentos que recuperam, na rede referencial, conhecimentos partilhados a respeito do referente em questão. A Coroa do Lugar, nome dado ao mausoléu, já suscita a ativação de valores a ele atribuídos histórico e culturalmente. Bem como, as pedras preciosas utilizadas em sua edificação - ametistas, safiras, jade etc. - se relembradas, criam um encaminhamento, delineado no processo discursivo, que permite reconhecer, na sequência, a articulação entre uma instância sociocognitiva já legitimada - domínio do garimpo - e os acontecimentos discursivos e interacionais que a interpelam - domínio da economia global atual.

Utilizando-nos de uma metáfora para explicarmos tal processo, temos que se estabelece uma ponte cognitiva (Taj Mahal $\rightarrow$ pedras preciosas $\rightarrow$ garimpo $\rightarrow$ mundo dos negócios), para que se compreenda o sentido sugerido no discurso. Isto porque examinamos que a metáfora O MUNDO GLOBAL DE NEGÓCIOS É UM GRANDE GARIMPO é acionada, posteriormente à menção feita sobre o monumento:

45 Acho que $a$ Índia está num momento excepcional da sua história porque, depois de tantas lutas, está travando uma outra grande luta, que é se descobrir para o mundo 
do negócio, nesse mundo globalizado. E é sobre isso que eu queria conversar um pouco com os empresários.

E no mundo dos negócios não tem milagre. Tem trabalho, persistência, perseverança. E isso é mais ou menos como garimpar. Ninguém acha a pedra preciosa em cima da terra. Ou nós garimpamos, cavamos os buracos necessários, carregamos a terra que for necessário carregar, nas costas, ou nós não encontramos o ouro, não encontramos as pedras preciosas que tanto procuramos. No mundo globalizado, o mundo do negócio é um grande garimpo. Nós temos que procurar o melhor negócio. E para fazermos o melhor negócio, temos que estabelecer as melhores parcerias. E é por isso que eu quero dizer a vocês, com a sinceridade que um homem pode conversar com outro homem, de que a visão de mundo comercial, ou a visão de mundo de negócios que o meu Governo tem é muito claro. E dizíamos isso antes das eleições. Estamos colocando em prática aquilo em que nós acreditávamos quando disputamos as eleições.

Primeiramente, depreendemos que um recorte avaliativo sobre o mundo dos negócios vai sendo constituído: "mundo dos negócios" (linha 53), “o mundo globalizado" (linha 58), “o mundo do negócio" (linha 58), "um grande garimpo" (linha 58). Mapear cognitivamente as situações globais de negócios a partir do domínio do garimpo consiste de um processo no qual categorias são criadas por meio da ativação de referências múltiplas no processo de referenciação.

A respeito da organização cognitiva convencional relacionada ao domínio do garimpo, esta corresponde à atividade de extrair riquezas minerais em localidades distantes e profundas da terra. Embora o trabalho dos garimpeiros seja reconhecido como árduo, por conta da necessidade de cavar buracos profundos, os resultados podem ser promissores. Para tal função, os agentes precisam de persistência, de força física e de muito trabalho. Neste viés, o domínio-fonte envolve elementos como: a) os agentes (garimpeiros), b) a ação de busca por pedras preciosas, que está ligada à força, à persistência, c) o local (terra, buracos profundos), d) o objeto buscado (pedras preciosas, ouro). Além disso, entendemos haver valores concretos, como o de riqueza, pelo qual se pode chegar ao de progresso e ao de moralidade, em termos de propiciar bem-estar às pessoas envolvidas.

\section{Essa metáfora, O MUNDO GLOBAL DE NEGÓCIOS É UM GRANDE GARIMPO,} viabiliza a construção de uma imagem da distância territorial existente entre Brasil e Índia. Também sugere que os melhores resultados em termos de negócios são obtidos nas localidades mais distantes. Assim, a formulação "as melhores parcerias" corresponde a uma categoria, constituída por meio da ativação dupla de referências (pedras preciosas $\rightarrow$ melhores 
parcerias). Neste viés, entendemos haver a conceptualização PARCERIA BILATERAL É PEDRA PRECIOSA.

Ainda a respeito dessa metáfora do garimpo, os objetos de discurso relacionados aos políticos e aos empresários brasileiros e indianos recebem propriedades das categorias do domínio do garimpo. Sugere-se que esses agentes tenham força e persistência, para que obtenham o resultado esperado (a melhor parceria, pedra preciosa), assim como agem os garimpeiros. Estas observações levam-nos a crer que o orador busca negociar sentido sobre o Brasil e, em específico, de sua área de negócios, de modo a reiterar a ideia da distância territorial como algo promissor e a motivar o auditório - empresários e políticos - a se interessar pelo que está longe em termos pré-conceptuais.

A metáfora da guerra, que aparece no início do segmento (54), às linhas 45-47, é selecionada para indicar a situação de negócios em que está o país (Índia). Por meio dela, sugere-se que existe uma relação de disputa na política internacional e se justifica a razão da necessidade de se ter força para lutar. A formulação que evidencia tal direcionamento corresponde àquela pela qual se categoriza a grande luta da Índia, descrita como: "uma outra grande luta, que é se descobrir para o mundo do negócio, nesse mundo globalizado" (linhas 46-47).

Observamos que tanto a metáfora do garimpo quanto da guerra, por mais que cumpram significativo papel no momento em que são selecionadas no pronunciamento, não são exploradas no desenvolvimento do discurso. Ao analisarmos a sequência do procedimento utilizado para produzir sentido à parceria Brasil e Índia, depreendemos que o investimento é direcionado para a ideia de unir categorias, para se criar força política e econômica. Neste viés, entendemos haver um jogo de seleções lexicais, no qual se privilegia um olhar voltado para a sobreposição de partes de categorias-contêiner, em um processo em que o sentido singular de cada uma é preservado e, ao mesmo tempo, articulam-se propriedades específicas de modo a criar a ideia do que é comum.

A argumentação por ligação de coexistência aparece como estratégia de evidenciar possíveis resultados positivos da relação bilateral. Na rede referencial, categorizar e recategorizar os países, de modo a ligá-los por um viés avaliativo, consistem em atitudes estratégicas de dar visibilidade ao conceito de parceria a partir da apresentação de propriedades concretas. Dessa maneira, mais uma vez, depreendemos que metáforas orientacionais e ontológicas colaboram para que se consiga orientar o auditório a ver dada situação por meio de um recorte que favorece a tese defendida. 
Nos segmentos (56) e (57), podemos constatar que a ideia de força, de grandeza e de propriedades comuns é evidenciada:

(56)

Mas até há pouco tempo a nossa relação com gigantes como a Índia, como a 70 China, como a Rússia, era muito pequena.

90 E passei a discutir com os meus companheiros: qual o papel que o Brasil tem para jogar? Quais os países que têm similaridade com o Brasil? Quais os países que têm os mesmos problemas e, possivelmente, as mesmas soluções que o Brasil? E chegamos à conclusão de que $a$ Índia tem muita similaridade com o Brasil. A única diferença é que $a$ Índia tem muito mais gente que o Brasil.

A sequência como as formulações referenciais são organizadas e o modo como se constituem por certas seleções lexicais indicam orientação argumentativa. Temos que as noções de força e de grandeza atrelam-se à expressão "a nossa relação com gigantes" (linha 69), em que a metáfora ontológica está subjacente e permite que se reconheça o Brasil a partir dos atributos dados a seus parceiros. Imagens reforçam-se a partir da estratégia da ligação, enfatizada pela seleção "a nossa relação". Em seguida, a ideia de unir o que é similar aparece de modo evidente: "os países que têm similaridade com o Brasil", "os países que têm os mesmos problemas e, possivelmente, as mesmas soluções que o Brasil”, "a Índia”, "a Índia" (linhas 91-94).

Outro procedimento aponta para uma subjacente base da cognição política internacional. A indicação de um espaço comercial ocupado por potências econômicas e a tese de se unir para "adentrar" nesse lugar correspondem ao encaminhamento do sentido dado pelo pronunciamento. É nesta acepção, de inclusão e de exclusão (dentro-fora), que o orador segue para motivar o auditório a aderir ao acordo proposto:

95 Mas o potencial de desenvolvimento, do crescimento interno, o conhecimento científico e tecnológico e as boas perspectivas da Índia adentrar no mundo globalizado, são praticamente as mesmas do Brasil. Então, porque não estabelecer uma relação estratégica e privilegiada com a Índia? Porque não discutimos as nossas necessidades? 
(59)

125 O Brasil se orgulha de poder ser a porta de entrada da Índia na América do Sul e no Mercosul.

(60)

Queremos que, com esse acordo entre Brasil e Índia, Brasil e África do Sul, tenhamos a força necessária para, na Organização Mundial do Comércio, a gente consiga ter lastro político para flexibilizar os produtos que, muitas vezes, os países

135 ricos impõem tarifas para impedir que façamos negócios. Não queremos parar na Índia e na África do Sul, queremos estabelecer forte relação com a China e com a Rússia. Queremos estabelecer forte relação com países da África do Sul e outros países africanos, para que a gente possa mudar um pouco o que eu chamei outro dia "a geografia comercial do planeta Terra".

Podemos entender que a ideia de reorganizar "a geografia comercial do planeta" (linha 139) está diretamente ligada à reorganização de categorias, suas hierarquias, suas divisões. Esta é a proposta do pronunciamento e o encaminhamento conceptual que se apresenta. Tal afirmação pode ser comprovada no próximo segmento, correspondente ao epílogo do discurso, principalmente por meio das formulações das linhas 193-195 que enfatizamos em itálico:

(61)

Boa sorte a todos vocês e que a aliança estratégica entre Índia e Brasil seja duradoura e permita que nós conquistemos o direito de que o nosso povo possa 190 tomar café, almoçar e jantar todo santo dia, e que possa estudar e viver dignamente. Isso só será possível se as nossas economias crescerem. E, para as economias crescerem, vamos precisar de investimentos, aqui e lá. Vocês podem ser o bom sinal que nós precisamos para que Índia e Brasil deixem de ser países subdesenvolvidos ou países em desenvolvimento e passem a fazer parte do grupo 195 privilegiado dos países ricos do planeta.

Muito obrigado e boa sorte a todos nós.

Sair da categoria dos países subdesenvolvidos ou países em desenvolvimento e se incluir na do grupo privilegiado, dos países ricos do planeta, consiste na estratégia de motivação do auditório. Isto quer dizer que se busca, pelo discurso, mudar a lógica convencionalizada a respeito da divisão existente na política internacional. Neste viés, riqueza e direitos humanos correspondem aos valores utilizados, para fortalecer a tese desenvolvida. 


\subsubsection{Relação Brasil-Quênia}

\subsubsection{Seminário Empresarial Brasil-Quênia (Nairóbi, 2010)}

Na capital do Quênia, Nairóbi, em seis de julho de 2010, ocorreu um encontro bilateral, em que o ex-presidente Lula proferiu um discurso para políticos e empresários quenianos e brasileiros. No exórdio, o orador utiliza-se de um tom mais informal em relação aos discursos que examinamos. Para ilustrarmos esta observação, selecionamos um segmento do início do pronunciamento:

05 Para não dizerem que o Brasil quer apenas vender ao Quênia, eu vou entregar ao Vice-Presidente um livro ensinando como exportar para o Brasil, para que o Quênia possa vender para o Brasil.

Esta foto nunca é publicada, mas vale para o arquivo do Stuckert. Eu, quando era dirigente sindical, que eu ia falar e que tinha muitos microfones na mesa, eu sabia 10 que tinha alguns que não funcionavam. Eu, aqui, não sei se eu falo para o vermelho, não sei se o mais importante é esse aqui, da televisão, mas [...]

O tom informal examinado nesse segmento pode ser considerado pista do tratamento dado à relação entre os dois países. Recorre-se também à informalidade, quando se ativa o objeto de discurso, correspondente aos interlocutores, a partir da formulação "os companheiros" (linha 27), selecionada por Lula, no Brasil, de modo frequente. Observemos tal procedimento em (63):

(63)

É importante que os companheiros do Quênia saibam que, quando começamos a fazer isso, éramos tratados por alguns como se fôssemos loucos: "Onde já se viu o Presidente do Brasil fazer viagem para a África, fazer viagem para o Caribe, fazer 30 viagem para a América Central, priorizar a sua relação com a América do Sul, visitar países árabes que, até então, só o Imperador tinha visitado, em 1870?”.

Na sequência, examinamos que a relação multilateral e a bilateral são construídas metaforicamente também de modo peculiar, ou seja, o tom informal continua aparecendo. Ao se referir à crise financeira mundial de 2006, ocorrida no mercado hipotecário dos Estados Unidos, Lula argumenta que o Brasil não foi atingido de maneira mais acentuada, em razão de o governo ter diversificado seus mercados globais. Neste viés, a tese do ex-presidente sustenta-se na ideia da necessidade de fazer negócios também com países em 
desenvolvimento, no sentido de desconcentrar o poder econômico global vigente. A respeito deste procedimento político, o orador seleciona o ditado popular "De grão em grão, a galinha enche o papo" (linha 44). Examinemos o próximo segmento, atentando às partes destacadas em itálico:

$[\ldots]$

Isso teve uma importância muito grande quando houve a crise mundial, a crise do subprime, nos Estados Unidos, em que o crédito desapareceu e o comércio diminuiu muito. É verdade que, no Brasil, ele também diminuiu, mas é verdade que ele diminuiu menos, porque nós tínhamos diversificado muito a nossa balança comercial. E aí é que entra a importância de recuperarmos um ditado popular que nós aprendemos desde pequenos: "De grão em grão, a galinha enche o papo". Ela

45 não consegue comer dez grãos de uma vez, é um a um, e, daqui a pouco, a galinha está tão gorda que a gente se vê no afã de comê-la.

Pois bem, nós estamos nessa política com o continente africano, em primeiro lugar, de grão em grão; nós estamos descobrindo que nós existimos; estamos descobrindo que cada um de nós, dentre as suas peculiaridades, tem potencial

50 extraordinário; nós estamos descobrindo que cada país, por menor que seja, tem alguma coisa a oferecer a outro e, portanto, ele tem possibilidade de estabelecer o desenvolvimento comercial que possa gerar desenvolvimento interno do seu país, crescimento econômico, e fazer com que os países possam participar da economia determinada pelos grandes países como uma economia desenvolvida nesse mundo globalizado.

Sobre esse ditado popular, no Brasil, há de se considerar que existe uma noção já préestabelecida do termo "comer de grão em grão", que é a de acumulação de pequenas coisas ou a de que uma ação deve ser feita passo a passo. Neste viés, valores concretos, como o de persistência, estão implicados em alguns usos desse conhecimento popular.

Embora saibamos que os ditados populares são elaborados por meio de metáforas (ativação de um domínio X associado a um Y), com o tempo, sua compreensão passa a se dar a partir de um conhecimento já fixado culturalmente. Isto corresponde a um processo social, interacional e dinâmico do discurso - que cumpre papel de interface dessa construção de saberes de uma população a respeito de situações de seu cotidiano. Entendemos que a seleção de ditados populares perante auditórios complexos - por serem compostos por pessoas de culturas distintas - possibilita que se suscitem efeitos singulares. Isto se deve ao fato de os políticos e os empresários africanos poderem não conhecer o ditado apresentado e, por tal razão, compreendemos haver surgimento de uma metáfora nova. É neste viés que associações 
de domínios díspares ganham olhares diferenciados, quando interagem com diferentes tradições culturais e organizações discursivas.

Essa observação embasa-se nos pressupostos de Perelman e Olbrechts-Tyteca (2002 [1958]), discutidos às páginas 167-168. Para estes estudiosos, metáforas podem ser selecionadas de modo a proporcionarem visões diferentes daquelas desenvolvidas convencionalmente. Tal efeito surge, quando determinada metáfora é inserida em uma situação inusitada. Neste viés, já o fato de o conhecimento sobre o ditado ser articulado ao do campo político internacional promove um encaminhamento peculiar, reforçado pela diferença de culturas e experiências coletivas.

O posicionamento de Kovecses (2005), a respeito de algumas metáforas serem baseadas em processos cognitivos de vários tipos e implicarem conhecimentos culturais, também embasa a observação do segmento (64) do pronunciamento feito no Quênia. O fato de a metáfora, em consonância com esse autor, produzir modelos culturais, representações mentais do mundo, que operam no pensamento, faz-nos compreender que a seleção do ditado "De grão em grão, a galinha enche o papo", encapsulado como "Nessa política com o continente africano" (linha 47), quando direcionado a estrangeiros e a brasileiros, consiste de um procedimento que privilegia uma específica organização do conhecimento e que, por meio dele, busca-se criar coerência à inter-relação Brasil e Quênia; entretanto, também consideramos que, para cada auditório particular, o processo não é o mesmo, em razão de haver variação "transcultural” (Kovecses, 2002), fator inerente às variadas e específicas maneiras de ver, de entender o mundo e o discurso, como também de agir sobre o primeiro por meio do segundo.

Entendemos que os responsáveis pela elaboração do discurso presidencial estão atentos a essa diversidade cultural, uma vez que, ao mencionar o ditado, o orador passa a explicá-lo, dando a conhecer aos políticos e aos empresários do Quênia o que se entende a respeito da formulação selecionada. Observa-se, assim, preocupação em fazer-se entender, de orientar o que se diz. Em relação aos empresários brasileiros presentes, temos que, para estes, também o ditado popular surge, promovendo sentido diferenciado, em razão de estar inserido em um cotexto, cujo tópico ativa um domínio singular: o de negócios entre países. A própria organização discursiva pode favorecer este processo.

Nessa acepção, examinamos que, no cotexto, o que vem antes do ditado popular recai sobre a diversificação da balança comercial do Brasil. Posteriormente, ocorre o encapsulamento: "Pois bem, nós estamos nessa política com o continente africano, em 
primeiro lugar, de grão em grão" (linhas 47-48). Tais procedimentos permitem-nos depreender que se associa a categoria "grão" ao país buscado como parceiro e, também, à ação de fazer negócio (uma atitude por vez).

Dessa forma, por um lado, chegamos à metáfora PAÍS-PARCEIRO É UM GRÃO. Por outro, as negociações multilaterais podem ser entendidas como: FAZER NEGÓCIO COM VÁRIOS PAÍSES EM DESENVOLVIMENTO É COMER DE GRÃO EM GRÃO. Assim, desenvolve-se a ideia de que a cada grão que se come (tentativa ou criação de parceria com um Estado), mais o país se fortalece. Em relação ao continente africano, o governo vai de grão em grão, isto é, tenta estabelecer parceria com os países da África e vice-versa. Isto ocorre não de imediato, mas sim passo a passo, como mencionado no segmento (64). Neste último sentido, em específico, grão pode ser entendido como ação política isolada (uma por vez).

Ainda existem as categorizações "cada país, por menor que seja" (linha 50) e "grandes países" (linha 54), pelas quais se observa um efeito de sentido privilegiado, que é a noção pequeno (país em desenvolvimento) vs. grande (país desenvolvido). É por este viés que o discurso segue, de modo que se possam evidenciar diferenças e determinar os limites entre os países em desenvolvimento e os desenvolvidos. A metáfora ontológica (grande vs. pequeno) e a orientacional, pela qual se delimitam espaços e separam-se objetos pela lógica dos contêineres, agem para convalidar a tese de unir para ganhar força, para tornar-se grande.

Joga-se com sistemas de crença, de metas e de princípios, para convalidar essa noção de união e, consecutivamente, de relação bilateral. Nesta parte do pronunciamento, concentram-se formulações referenciais, pelas quais se recorre à relação nós vs. eles. Observemos os segmentos destacados em (65) e (66):

\section{$[\ldots]$}

55 E, aí, é importante... Você foi muito gentil, (incompreensível). Eu vou colocar aqui na expectativa de que o Ivan Ramalho não tome a minha água. E aí é importante a gente descobrir a nossa origem, ou melhor, não esquecer a nossa origem, não esquecer como é que nós começamos a nossa vida econômica, não esquecer nunca que todos nós fomos colonizados [...] (noção de nós)

(66)

Eu estou querendo dizer com isso é que nós somos muito, muito jovens na confecção da nossa democracia e que, portanto, foram aqueles que nos 
colonizaram que determinaram o tipo de coisa que deveria acontecer conosco. E, muitas vezes, nós ainda temos, hoje, a economia dependente daqueles que nos colonizaram. (noção de eles)

Mais uma vez, podemos depreender que as circunstâncias específicas da política internacional favorecem a busca por cooperação. A formação de um grupo requer que se reconheçam interesses comerciais e políticos, ou mesmo, valores e crenças semelhantes. Neste viés, há ativação de sistemas ideológicos, os quais permitem que se conduza à autorrepresentação de um grupo (Van Dijk, 2005, 2008). A noção de pertencer à mesma histórica permite que os participantes da interação reconheçam e assumam lugares sociais comuns em termos políticos e culturais. Nesta direção, categorias são criadas e organizam o espaço político global, favorecendo um viés axiológico.

Ainda, a relação nós vs. eles, apresentada no pronunciamento, orienta uma sanção a respeito de quem pode ou não pertencer ao grupo e como se deve agir a partir do momento em que um Estado se torna membro. A respeito deste comportamento específico, é a metáfora do percurso que aparece e possibilita a ideia de ação conjunta, tal como podemos examinar em (67):

(67)

Porque não pode ser uma relação sadia o Brasil, por ser uma maior economia; o 95 Brasil, por ter mais tecnologia, querer vir ao Quênia só para vender. Nenhum país do mundo aguenta só comprar. É preciso que essa boa política entre dois países e essa política comercial seja uma via de duas mãos [...] (noção de nós)

Nesse segmento, os objetos de discurso "essa boa política entre dois países" e "essa política comercial" (linhas 96-97) situam-se no domínio-fonte da jornada. A formulação "uma via de duas mãos" (linha 97) está diretamente relacionada ao encaminhamento de sentido sobre a relação bilateral entre Brasil e Quênia, dado pela organização discursiva. Por ela é que se sugere a ação recíproca como essencial na constituição de uma "boa política entre dois países", linha 96, caso se realize futuramente. Embora tal metáfora não seja desenvolvida posteriormente, pode-se dizer que sua seleção cumpre importante função argumentativa, uma vez que se orienta um recorte avaliativo a respeito de Brasil e Quênia, em um momento do discurso, no qual vem se construindo a relação bilateral. É no jogo entre como está (presente 
do discurso) e como deve ficar (futuro do discurso) que se cria uma situação discursiva, a qual favorece a tese do orador.

Nessa direção, o encaminhamento dado ao discurso consiste na apresentação de uma fase política global de mudança, a qual reforça a ideia da necessidade de os agentes adotarem novas posturas. No segmento (68), em específico, as formulações destacadas, às linhas 107109 ,

105 E aí, sim, é que é preciso tomar cuidado para que a exploração desses minérios não se dê como se deu no começo do século XX, de forma totalmente predatória, em que $o$ país mais rico tirava tudo e pagava quase nada. É preciso estabelecer uma nova relação, uma nova fase de respeito, um novo marco jurídico que garanta o direito de sobrevivência. (noção de nós vs. eles)

dão a conhecer que o grupo de Lula (dos países em desenvolvimento) corresponde àquele que respeita e garante direitos específicos. Assim, o domínio-alvo "relação bilateral" é mantido em foco no discurso e vai ganhando certas qualificações, a partir da noção de Estado-pessoa. Posteriormente, formulações, como "esse país que quer se irmanar ao Quênia”, comprovam que a ideia de união vai sendo favorecida por meio da associação país e pessoa. Observemos, no segmento (69), os elementos em itálico:

(69)

E é por isso que nós dizemos aqui... Eu dizia ao Presidente do Quênia que

110 o Brasil é um país muito diversificado, ou seja, nós temos regiões muito pobres no Brasil e, ao mesmo tempo, nós temos regiões muito ricas no Brasil. O Brasil é um país que tem a segunda ou a primeira mineradora do mundo; o Brasil é um país que é o maior produtor e vendedor de suco de laranja do mundo; o Brasil é o maior vendedor de carne de frango do mundo; o Brasil é o maior vendedor de carne de

115 boi do mundo; o Brasil é o que tem mais tecnologia na produção de etanol e de biodiesel; o Brasil é o terceiro produtor de avião do mundo; o Brasil é o quinto produtor de carros do mundo. Ou seja, o Brasil é um país... é uma mistura de um país sofisticado tecnologicamente e uma mistura de um país esquecido, que é a parte mais pobre do Brasil, que é o Norte e o Nordeste brasileiro. É esse país que

120 quer se irmanar ao Quênia; é esse país que quer trazer pra cá a nossa experiência na produção de etanol, na produção de açúcar, na produção de biocombustível ou de biodiesel, com a palma africana; é esse país que, como a Marcopolo, pode vir aqui montar carroceria de ônibus e montar ônibus. [...] 
As seleções destacadas indicam que o Brasil é apresentado como pessoa: paísprodutor, país-vendedor etc. Tal procedimento leva-nos a depreender que a relação bilateral, nesta parte, consiste também em uma relação entre pessoas (“esse país que pode vir aqui”, linhas 122-123) com características, provavelmente, consideradas significativas em termos de negócios: vontade ("esse país que quer", linha 120), competência ("o maior produtor e vendedor", linha 113). Além do mais, a metáfora ontológica aparece na relação "grande" vs. "pequeno", de modo a reiterar a ideia de unir forças, sugerida como sentido de relação bilateral entre Brasil e Quênia.

De modo geral, à página 106, quando discutimos sobre o fato de que selecionar um país como parceiro, em vez de outro, já implica certas elaborações de ordem discursiva, também mencionamos que tal procedimento leva a associar especificidades de um e de outro, de tal modo que o auditório possa reconhecer a parceria como algo promissor e o paísparceiro com interesses e características comuns. É o que ocorre nesse pronunciamento.

\subsubsection{Brasil e Mercosul}

\subsubsection{1. $39^{\circ}$ Reunião de Cúpula do Mercosul (2010)}

Em relação às visitas multilaterais feitas pelo ex-presidente da República, discutimos que o Mercosul (Mercado Comum do Sul) foi visto como primordial na política externa do governo Lula. Na $39^{\circ}$ Reunião de Cúpula do Mercosul, em três de agosto de 2010, em San Juan, houve um pronunciamento, no qual foi discorrido a respeito desse grupo. Depreendemos que o pronunciamento é encaminhado de maneira a construir duas imagens do Mercosul: o que é e como deve ficar.

Observamos que, no desenvolvimento do discurso, o orador debruça-se sobre o Mercosul de modo constante. A seleção "Mercosul" foi apresentada trinta vezes e, a partir dela, foram atribuídas qualificações por meio de definições e formulações referenciais. $O$ entrelace das informações presentes nos levou a identificar, principalmente, metáforas orientacionais, ontológicas e a da jornada. Outras seleções lexicais que reativam tal objeto de discurso também foram examinadas.

Primeiramente, examinemos alguns segmentos, nos quais a imagem de como é o Mercosul vai sendo delineada: 
(70)

O Mercosul foi pioneiro ao criar o Sistema de Pagamento em Moedas Locais. O sistema começou com a Argentina e vamos implementá-lo agora com o Uruguai.

O Mercosul é grande. Maior do que alguns pequenos pensam que é. Por isso devemos celebrar com entusiasmo os 20 anos do nosso projeto, quando de seu aniversário em março de 2011.

(71)

60

É hora de pensar os próximos vinte anos do Mercosul. Temos de definir o que queremos para o nosso projeto de integração.

(72)

Nos seus primeiros vinte anos, o Mercosul foi principalmente um projeto econômico-comercial.

65 Nos próximos vinte, temos de aprofundar a dimensão política, social e cultural do bloco.

Nos segmentos (70), (71) e (72), observamos que o Mercado Comum do Sul recebe, entre outras, categorizações pelas quais características são ressaltadas: "pioneiro" (linha 53), "grande" (linha 55), "o nosso projeto de integração" (linha 60), "um projeto econômicocomercial” (linhas 63-64), "o bloco" (linhas 65-66). Entre estas seleções, pode-se dizer que "grande" e "bloco" consistem na ativação da metáfora ontológica, a partir da qual se torna possível caracterizar o abstrato, o distante, por meio do concreto. Isto porque compreendemos que criar conceito a respeito da relação multilateral corresponde à atitude de trazer, por exemplo, conhecimentos empíricos partilhados relacionados ao domínio das coisas palpáveis. Tal procedimento também pode ser observado nos próximos segmentos. Examinemos as linhas destacadas em itálico:

(73)

Ao mesmo tempo devemos ampliar as condições para provar que o crescimento compartilhado é mais sólido e duradouro que os projetos isolados e alimentados por falsas rivalidades.

$70 \quad$ O Mercosul não é mais só uma iniciativa dos Estados. Pertence às forças vivas da sociedade.

O Mercosul tem de ser a cara das pessoas e as pessoas precisam se reconhecer nele. Temos de construir o Mercosul dos povos.

Atribuir qualificações ao Mercosul, como grande, bloco e sólido, consiste de um procedimento, pelo qual a concentração recai sobre a "forma", para que o auditório reconheça atributos positivos e necessários em termos de grupos políticos internacionais. Além do mais, propõe-se um novo Mercosul, relacionado às pessoas. E é neste viés que a metáfora da personificação atua, pois, ao imprimir a imagem do grupo, esta é associada a 
rostos humanos, criando uma noção de identidade dos povos, reforçada pela categorização "O Mercosul dos povos" (linha 73). Trata-se de uma fusão de imagens, que permite visualização da tese do orador.

É nessa direção que se propõe um novo "Mercosul":

E temos de ouvir mais os jovens. Ajudar a difundir entre eles uma consciência da sua identidade como cidadãos do Mercosul.

Um Mercosul jovem é um Mercosul mais dinâmico, mais inovador, mais próspero.

É o Mercosul do futuro. Necessitamos de uma "geração Mercosul".

A ativação do objeto de discurso "os jovens" (linha 101) permite que se reformule a noção de Mercosul. Mais uma vez, ocorre fusão de imagens, a partir da qual atributos relacionados aos jovens (dinâmico, inovador, próspero) vão constituindo como deve ser (efeito futuro) o Mercosul. Assim, a formulação indefinida "um Mercosul jovem” (linha 103) é retomada pela definida "o Mercosul do futuro" (linha 104) e ambas estão, indiretamente, associadas a "uma geração Mercosul” (linha 104).

Tais procedimentos reforçam um encaminhamento cognitivo e argumentativo. $\mathrm{O}$ "Mercosul do futuro" deve ser composto por pessoas com características joviais e isto imprime, novamente, a ideia de mudança de postura. Sugere-se que agentes estejam engajados no processo político de modo dinâmico e inovador. Os feitos dessas atitudes futuras são visualizados pela metáfora do percurso, relacionada à orientacional e à ontológica, selecionadas na sequência do discurso:

(75)

Com o expressivo dinamismo das economias emergentes, o Mercosul deve engajar-se ainda mais em diálogos que visem a reforçar o comércio e a cooperação Sul-Sul.

140 O Acordo firmado com o Egito nesta reunião é prova da disposição do bloco para prosseguir nesse objetivo.

(76)

O Mercosul está olhando, cada vez mais, para toda a América do Sul e para a América Latina e o Caribe.

150 Quero saudar o companheiro Néstor Kirchner, que, com seu conhecimento e experiência política do nosso continente, está sendo um extraordinário SecretárioGeral da UNASUL.

É preciso traduzir a reafirmação do projeto de integração regional - impulsionada pela criação da UNASUL e pelas Cúpulas de Sauípe e de Cancún - em benefícios concretos para nossos povos. 
A conclusão do processo de adesão da Venezuela ao Mercosul é passo importante nessa direção.

(77)

160 Ao amparo do Acordo com o nosso bloco, o México e o Brasil dialogam sobre caminhos possiveis para abrir novas oportunidades de comércio e investimentos recíprocos.

(78)

Mas podem ter certeza de que vou empenhar-me, de todas as formas, para que o Mercosul continue avançando como exemplo de integração solidária, voltada para a promoção da paz, segurança, democracia e desenvolvimento com justiça social.

O Mercosul, situado no domínio-fonte da jornada, recebe, deste, especificidades: a direção que deve ser seguida, os objetos que serão encontrados pela frente, os impulsos, o passo. Neste viés, a situação construída no discurso é estruturada pela metáfora conceptual, e Mercosul torna-se agente em ação. Observamos que se defende a noção de não ficar parado, em razão de o sentido de avançar, de se movimentar para frente, está ligado à ideia de atitude promissora: "benefícios concretos para nossos povos" (linhas 154-155), "abrir novas oportunidades de comércio e investimentos recíprocos" (linhas 161-162), "promoção da paz, segurança, democracia e desenvolvimento com justiça social” (linha 178).

\subsection{Processos referencial-metafóricos da corrupção e da moralidade}

\subsection{1. $4^{0}$ Fórum Global de Combate à Corrupção}

Em sete de junho de 2005, no hotel Blue Tree Park, em Brasília, houve um encontro com líderes políticos mundiais, cujo tópico versou sobre a corrupção. Nessa época, existiam denúncias de corrupção, as quais envolviam membros do governo federal do Partido dos Trabalhadores (PT). Acreditamos que, por tal razão, ao dizer sobre o assunto em pauta, o expresidente procede à justificativa e à manutenção de uma imagem pública voltada para a moralidade.

Ao analisarmos tal pronunciamento, depreendemos, primeiramente, que o orador conduz seu discurso de modo a evidenciar uma situação de guerra. Por um lado, há os agentes defensores da sociedade, por outro, os corruptos. Nesta situação constituída discursivamente por meio do domínio-fonte da guerra, alguns objetos de discurso são ativados e cumprem o papel de reforçar a noção de conflito defendida. Muitos deles convalidam características específicas do então governo e de seu chefe, tais como a de força, 
de persistência, de honestidade e de cumprimento de seus deveres. Observemos alguns segmentos, em que formulações que produzem efeitos dessa ordem estão presentes:

(79)

Ao assumir o governo, em 2003, sabíamos que a luta seria dura e exigiria muita firmeza e persistência. Desde o primeiro dia dedicamos todo o nosso esforço ao combate, sem trégua, a essa triste herança secular. Decidimos, assim, aperfeiçoar os mecanismos institucionais já existentes e criar novos, para defender ao máximo os bens e os recursos públicos.

Nosso governo passou a planejar e a agir de modo integrado, na luta contra a corrupção.

Por determinação minha e do Ministério da Justiça, a Polícia Federal, de agosto de 2003 a maio de 2005 , realizou 46 operações dirigidas especificamente ao combate à corrupção.

Nosso governo está firmemente empenhado no combate e no mau uso dos recursos públicos e ao crime organizado. Transformamos a luta contra a corrupção numa atividade permanente ampla e que vai se intensificar cada vez mais. Mas para pôr fim à corrupção é preciso que a impunidade não proteja os corruptos, é importante

135 que eles se sintam constantemente ameaçados e sintam que o governo e a sociedade estão vigilantes, que estamos tomando as medidas preventivas, fechando o cerco, apurando toda e qualquer denúncia, envolva quem envolver.

O que tem aumentado, no Brasil, não é a corrupção, mas o constante combate que o governo faz à corrupção.

Os objetos de discurso ativados estão inseridos neste domínio da guerra e, dele, recebem ajustes que conduzem a uma orientação argumentativa. Embora não esteja, por vezes, o sentido metafórico na seleção lexical referencial, este se dá na organização discursiva, a partir do momento em que a referenciação é atrelada a um domínio conceptual específico. Neste viés, formulações como "nosso governo", "o governo", "os corruptos" podem ser associadas às categorias do domínio-fonte: os primeiros são os guerreiros, e os segundos, os inimigos.

Na sequência, outras partes, que consideramos significativo destacar, consistem na etapa do pronunciamento, em que a corrupção é conceptualizada como doença. Tal procedimento serve como condução cognitiva da tese que virá posteriormente, relacionada à promessa de Lula de "cortar na própria carne" (cf. p.129). Examinemos: 
(84)

Meus amigos e minhas amigas, sei que vocês passarão alguns dias no Brasil, 160 debatendo esse assunto que é um mal, é uma chaga no mundo inteiro, mas que penaliza mais os países mais pobres do mundo.

Ao encapsular um segmento a respeito da corrupção no mundo, procede-se a categorizá-lo negativamente a partir da definição "é um mal” (linha 160). Posteriormente, entendemos que a classificação corresponde à associação de domínios (política e corpo humano). Neste caso, evidenciam-se a noção de sofrimento e a do não cumprimento dos direitos humanos. O posicionamento apresentado, portanto, pauta-se por valores abstratos, viabilizados pela imagem de corpos com chagas.

Parece-nos que a função argumentativa de tal procedimento se torna mais evidente, quando a reativação do domínio-fonte do corpo humano reaparece e conduz à ideia de um líder que preza pelo bem-estar de seu povo e que está disposto ao sacrifício, se assim for necessário. Temos, neste viés, orientação argumentativa, dada por meio de uma organização de conhecimentos específicos às experiências corpóreas. Os próximos segmentos mostram o encaminhamento dado pelo pronunciamento:

(85)

Eu não poderia concluir minhas palavras sem mencionar fatos que já foram mencionados pelo representante do nosso querido Secretário-Geral das Nações Unidas, Kofi Annan, que tem sido objeto de atenção pública nas duas últimas

165 semanas, particularmente nos últimos dias.

Refiro-me à denúncia sobre corrupção que estaria afetando os poderes Executivo $e$ Legislativo. Independentemente do uso político-eleitoral que alguns estejam fazendo dessas denúncias, quero deixar claro que no meu governo, que o meu governo levará as investigações até as últimas conseqüências.

(86)

Por isso, jurei à Constituição do Brasil, por isso, sou o principal guardião das

170 instituições deste país. Estou plenamente confiante de minhas atribuições como primeiro mandatário e, como disse no meu discurso, como funcionário público número um do país.

Tenho, sobre meus ombros, responsabilidades que vão mais além da preservação das instituições. Sou o responsável maior pelos rumos de nossa economia e não

175 esqueci, em momento algum, dos compromissos que assumi com mais de 50 milhões de brasileiros e brasileiras que me trouxeram à Presidência da República e, também, com todo o povo brasileiro.

[...] No dia de hoje, determinei aos ministros uma solução definitiva para os 
185 problemas envolvendo os Correios e o Instituto de Resseguros do Brasil, resultando no afastamento dos diretores de ambas as instituições, sem prejuízo da continuidade das investigações. Digo que cortaremos na própria carne, se necessário. Sem prejulgar ninguém, e respeitando o direito a defender-se, que todo cidadão ou cidadã possui, não vamos vacilar um segundo na defesa do interesse da coisa pública.

O que está em jogo não são alguns parlamentares, funcionários, ministros. O que está em jogo é a respeitabilidade de nossas instituições, das quais sou o principal guardião, neste país.

Em (85), a formulação "fatos que já foram mencionados pelo representante do nosso querido Secretário-Geral das Nações Unidas, Kofi Annan, que tem sido objeto de atenção pública nas duas últimas semanas, particularmente nos últimos dias", às linhas 162-165, ativa conhecimentos, correspondentes às denúncias de corrupção no governo brasileiro. Pode-se examinar que tal situação teve repercussão internacional e poderia influenciar a imagem pública do governante e do governo.

Mais adiante, em (86) e (87), o investimento recai sobre a manutenção da imagem pública do orador. A maneira como esta é delineada no processo referencial oferece-nos pistas de se tratar de uma estratégia de estabelecimento de controle sobre a situação em pauta (denúncia de corrupção relacionada ao governo brasileiro). Nesta acepção, as formulações “o principal guardião das instituições deste país” (linhas 169-170), "funcionário público número um do país" (linhas 171-172), “o responsável maior pelos rumos de nossa economia” (linha 174), "o principal guardião" (linhas 192-193) consistem em categorizações as quais reforçam a responsabilidade assumida e corresponde a um modo de lidar com uma situação, vista como problemática e imoral.

Podemos afirmar que é isso que se espera de um presidente da República: cumprimento de suas responsabilidades e ação em prol dos interesses públicos. Por tal razão e pelo fato de o orador ser o chefe do Estado brasileiro, há necessidade de reconhecer o que é viável assumir para si, a fim de criar condições para que a tese proposta seja aceita.

A argumentação que se observa está ligada à correlação entre a imagem de um membro e seu grupo, levando-se em conta a estratégia de sucessão de Perelman e OlbrechtsTyteca ([1958], 2002), discutida à página 141 deste trabalho. No caso do pronunciamento sob análise, a valorização do orador torna-se fundamental, uma vez que o julgamento que se faz dele pode ser estendido ao governo e ao país. E é nesse cenário discursivo - no qual se apresenta uma situação de imoralidade e um líder que assume suas responsabilidades - que se 
ativa o domínio-fonte do corpo humano, para que se dê visibilidade à proposta do orador de resolver o problema da corrupção.

Como analisamos no capítulo 3 (Cf. p.140-141), o orador recorre à imagem de um organismo, que pode não estar saudável - "Digo que cortaremos na própria carne, se necessário" (linha 187) - de modo a dar sentido à situação de problema moral e convalidar seu posicionamento, o de defender "o interesse da coisa pública" (linhas 189-190).

Em razão de a moralidade ser utilizada como atributo de uma imagem pública, uma vez que se afirma haver preocupação com o bem viver da sociedade brasileira, retomamos o postulado de Lakoff e Johnson (1999), discutido às páginas 144-145 deste trabalho, referente ao fato de que os conceitos morais fundamentam-se por metáforas oriundas da natureza de nossos corpos e das experiências que as pessoas têm em várias interações sociais.

A partir dessa acepção que norteia o conceito de moralidade, entende-se que a tese de a corrupção poder ser uma chaga e a apresentação da condução do ex-presidente da República conduzir à ideia de sacrifício - mutilação de um membro do corpo - consistem em procedimentos argumentativos, embasados pelo domínio-fonte da corporeidade, por meio do qual se ativam experiências com sensações físicas. Assim, a ativação conceptual se repete, organiza informações e promove orientação argumentativa.

A afirmação de Perelman e Olbrechts-Tyteca (2002 [1958]) a respeito da relação de coexistência entre o grupo e seus membros (cf. p.141), permite dizer que, quando o orador afirmar "cortaremos na própria carne", destaca-se a estratégia de excluir determinados membros, cujas atitudes não se coadunam com a proposta grupal; uma vez que se enuncia a incompatibilidade de alguns, pode-se garantir a imagem pública positiva dos outros políticos petistas e governistas e, principalmente, a de Lula, que se constrói como "o principal guardião", portanto, como líder político que precisa manter credibilidade perante auditórios múltiplos.

A presença de formulações como as analisadas, em (87), leva-nos a conceptualizações inter-relacionadas como: GRUPO DE PETISTAS É UM CORPO, LULA É A CABEÇA DO CORPO; GOVERNO É UM CORPO, POLÍTICOS GOVERNISTAS SÃO PARTES DO CORPO, CORRUPÇÃO É UMA DOENÇA.

Na sequência, observamos que o domínio-fonte do corpo humano continua sendo utilizado e associado à corrupção. Em (88), desloca-se a atenção para a situação mundial e mostra-se que existem posturas corruptas, cujas vítimas correspondem aos pobres. Já em (89), 
volta-se para o Brasil, dando a conhecer que não consiste de um fato isolado. Observemos as seguintes formulações destacadas:

(88)

Meus amigos e minhas amigas, eu tenho viajado o meu país nesses últimos anos. Tenho viajado o mundo e, em todos os lugares que vou, a questão da corrupção é quase que uma doença incurável, parece incurável às vezes, uma doença que 225 parece que ataca os mais pobres, porque a corrupção não prejudica os mais ricos. Ela prejudica sempre aqueles que mais precisam que o Estado possa lhes beneficiar com políticas públicas.

(89)

Estamos perto de acabar a corrupção? Certamente que não, porque ela é uma coisa crônica, ela está incrustada, muitas vezes, na alma; ela está incrustada, muitas 285 vezes, na consciência do corrupto; ela está incrustada, muitas vezes, na impunidade que os corruptos sempre tiveram, na história deste país. São raros os casos, muitas denúncias, muitas manchetes, muitos discursos, e o resultado é pouco.

Em (88) e (89), observamos que a corrupção é (re)categorizada da seguinte maneira: "quase que uma doença incurável" (linha 224), "uma doença que parece que ataca os mais pobres" (linhas 224-225), “a corrupção" (linhas 283), "uma coisa crônica” (linhas 283-284), “incrustada, muitas vezes, na alma” (linha 284), "incrustada, muitas vezes, na consciência do corrupto" (linhas 284-285), "incrustada, muitas vezes, na impunidade que os corruptos sempre tiveram" (linhas 285-286). Tais seleções lexicais metafóricas revelam o cenário discursivo criado para representar a situação de corrupção. $O$ viés da doença mantém-se e permite que criem sensações contrárias ao bem viver, em razão de se atribuir à questão características advindas de um organismo doente, de tal modo que se possa dizer que não há solução, uma vez que se categoriza a situação como crônica e quase incurável.

A respeito desse procedimento, mencionamos, à página 38, nosso pressuposto de que, ao apresentar uma entidade com especificidades dos seres humanos ou de seus corpos, experiências sensoriais - visuais, auditivas, gustativas, olfativas, táteis e espaciais - poderiam ser invocadas, de maneira a possibilitar aproximação entre o auditório e uma situação que estaria distante dele em termos de concretude. É o que entendemos ocorrer com o procedimento de construir a corrupção em termos de doença incurável, e a solução pelo viés do sacrifício, da mutilação, em razão de se poderem orientar sensações múltiplas, associações sensoriais. 
O procedimento de associar corrupção a uma doença que está na alma de algumas pessoas e que vitima "os mais pobres" (linha 225), "aqueles que mais precisam que o Estado possa lhes beneficiar com políticas públicas" (linhas 226-227), corresponde a uma maneira de afirmar que a solução do problema não é fácil. Sugere-se, portanto, a dificuldade de se alcançar o que está na alma, o que é quase crônico ou mesmo incurável. Nesta direção, entendemos que se indica a possibilidade de agir com algo relacionado ao corpo e, dificilmente, com o que é da alma.

No exame dos segmentos (88) e (89), tem-se a busca por se assegurar uma imagem relacionada à moralidade. Tal acepção mantém-se em (90), quando o investimento recai sobre a promessa de ser “exemplo de combate à corrupção", à linha 298:

295 Quero terminar dizendo aos congressistas que estão aqui: podem estar certos de que se tiver uma contribuição que o Brasil pode dar ao mundo, além das coisas boas, o futebol e do samba, que nós fazemos muito bem, podem ficar certos que nós queremos ser para o mundo também exemplo de combate à corrupção e de fim da impunidade num país em desenvolvimento como o nosso querido Brasil.

Ao encerrar o pronunciamento, conhecimentos correspondentes à metáfora da guerra “exemplo de combate à corrupção" (linha 298) - são reativados e conduzem à ideia de força para agir dentro de um sentido global do discurso que privilegiou as dificuldades encontradas por um líder político e seu grupo, em razão de ser a corrupção algo já existente e de estar além do empírico.

\subsection{Conclusão das análises}

Pelas análises realizadas, verificamos que o corpus de nosso trabalho, em razão de se constituir por pronunciamentos caracterizados pela diversidade cultural de seus auditórios e por objetivos interacionais específicos configurados em cada interação, propiciou que observássemos seleções de metáforas centrais referenciadoras, pelas quais se delinearam cenários discursivos diversos e específicos na organização discursiva - cada um foi alinhado às especificidades do encontro. 
Pudemos detectar que a metáfora tanto consiste de um recurso da referenciação e da argumentação - um saber utilizado estrategicamente em momentos oportunos dos pronunciamentos - quanto corresponde a um elemento estruturador dos processos referenciais e da coerência do discurso. Isto porque, por um lado, examinamos que as seleções metafóricas colaboraram com as teses apresentadas, sobretudo, pelo fato de cada discurso ter tido uma composição única, de vários conhecimentos de domínios diversos e de suas bases axiológicas, parcialmente associadas. Por outro, a própria organização que se deu a um mundo discursivamente delineado ocorreu por meio da lógica dos contêineres e de sua materialização linguística que forneceu recortes axiologicamente enviesados e articulações de diversas ordens.

Nas análises dos pronunciamentos ocorridos em Davos, itens 4.1.1. e 4.1.2, examinamos que é por meio de metáforas estruturais específicas, como a da construção e a da jornada, estas articuladas às orientacionais e às ontológicas, que se tornou possível trazer valores concretos, pertinentes às relações humanas, tais como os deveres dos governantes com os governados, dos pais com seus filhos, para se chegar aos abstratos. Assim foi possível organizar e construir no e pelo discurso conceitos como justiça e injustiça sociais, igualdade e desigualdade, (falta) liberdade, (falta) de paz etc. Nesta direção, o orador fortaleceu sua argumentação a partir da utilização daquilo que é socialmente aceito: as diretrizes dos direitos humanos internacionais.

Em 4.1.1, observamos que se criou uma imagem específica de desigualdade social a respeito da situação social vigente por meio de processos referenciais, viabilizados pela metáfora orientacional - "os que comem dos famintos, os que têm trabalho dos desempregados, os que moram dignamente dos que vivem na rua ou em miseráveis favelas, os que têm acesso à educação e ao acervo cultural da Humanidade dos que vivem mergulhados no analfabetismo e na mais absoluta alienação" (linhas 67-70) - e pela da família - "a fome, que atinge dezenas de milhões de irmãos e irmãs brasileiras" (linhas 28-29). Estas seleções lexicais, entre outras, permitiram que se associassem características empíricas àquilo que é abstrato (desigualdade social), favorecendo a apresentação de valores concretos - deveres dos líderes políticos, direitos e deveres entre os seres humanos - de maneira a alcançar e a ilustrar um valor socialmente aceito: o de justiça social - que embasa o ponto de vista defendido no pronunciamento. O seguinte esquema, pertinente ao pronunciamento ocorrido em Davos, em 2003, ilustra tal processo, da maneira como nós o entendemos: 


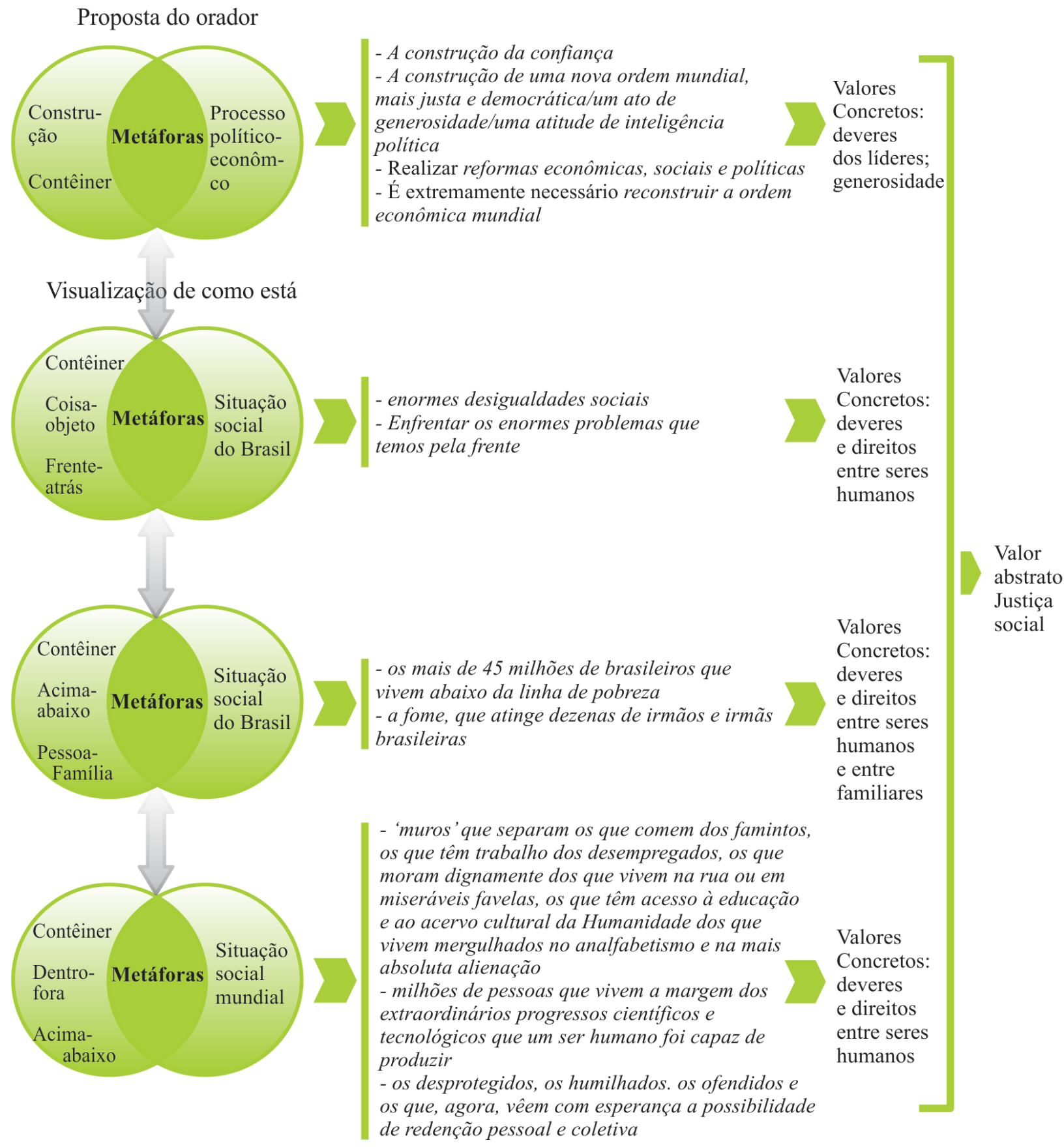

Figura 6. Davos, 2003: esquema referencial-argumentativo

Nesse mesmo pronunciamento, pudemos detectar que a rede referencial, em que a metáfora do contêiner, principalmente, favoreceu a concepção de desigualdade, organizou-se de maneira específica. Para ilustrar como as categorias-contêiner puderam favorecer a ideia da falta de igualdade, de justiça, e a tese da necessidade de mudança, elaboramos o esquema a seguir: 


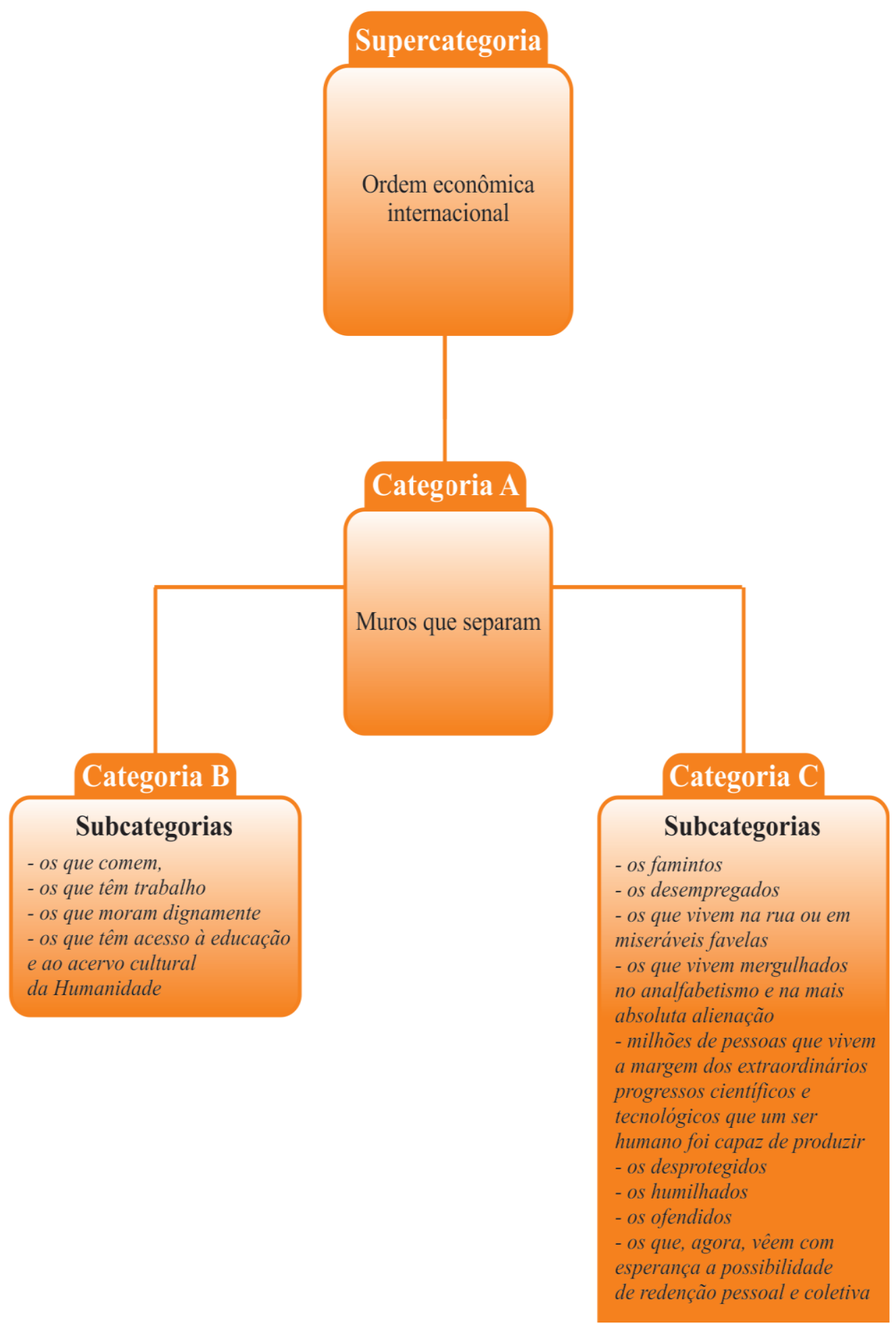

Figura 7. Davos, 2003: organização de categorias conforme a lógica dos contêineres

A respeito da figura 07 , mencionamos, no capítulo 2, a respeito de nosso pressuposto de as lógicas das categorias consistirem nas dos contêineres e indicamos que estes colaboram para a classificação, a organização e a compreensão de fatores e de situações sociais. Nesta acepção, no pronunciamento, foi na maneira como se categorizou, dividiu-se, que se 
evidenciaram as semelhanças e as diferenças existentes entre dois grupos (os pobres e os ricos). Ainda, há de se considerar que houve recorrência da indicação dentro-fora e da acimaabaixo, enfatizando que o valor da justiça não estava sendo seguido. Nesta mesma direção, detectamos categorias-contêiner, organizadoras de um cenário discursivo alinhado à tese de cada pronunciamento nos itens 4.1.2 (Davos, 2005), 4.1.3 (ONU, 2004), 4.1.4 (China, 2004), 4.2.1.1 (Portugal, 2003), 4.2.1.2. (Portugal, 2005), 4.2.2.1 (Índia, 2004), 4.2.3.1 (Quênia, 2010), 4.2.4.1 (Mercosul, 2010), 4.3.1 (Brasília, 2005).

Observemos mais uma ocorrência dessa ordem, a respeito do item 4.1.3 (ONU, 2004):

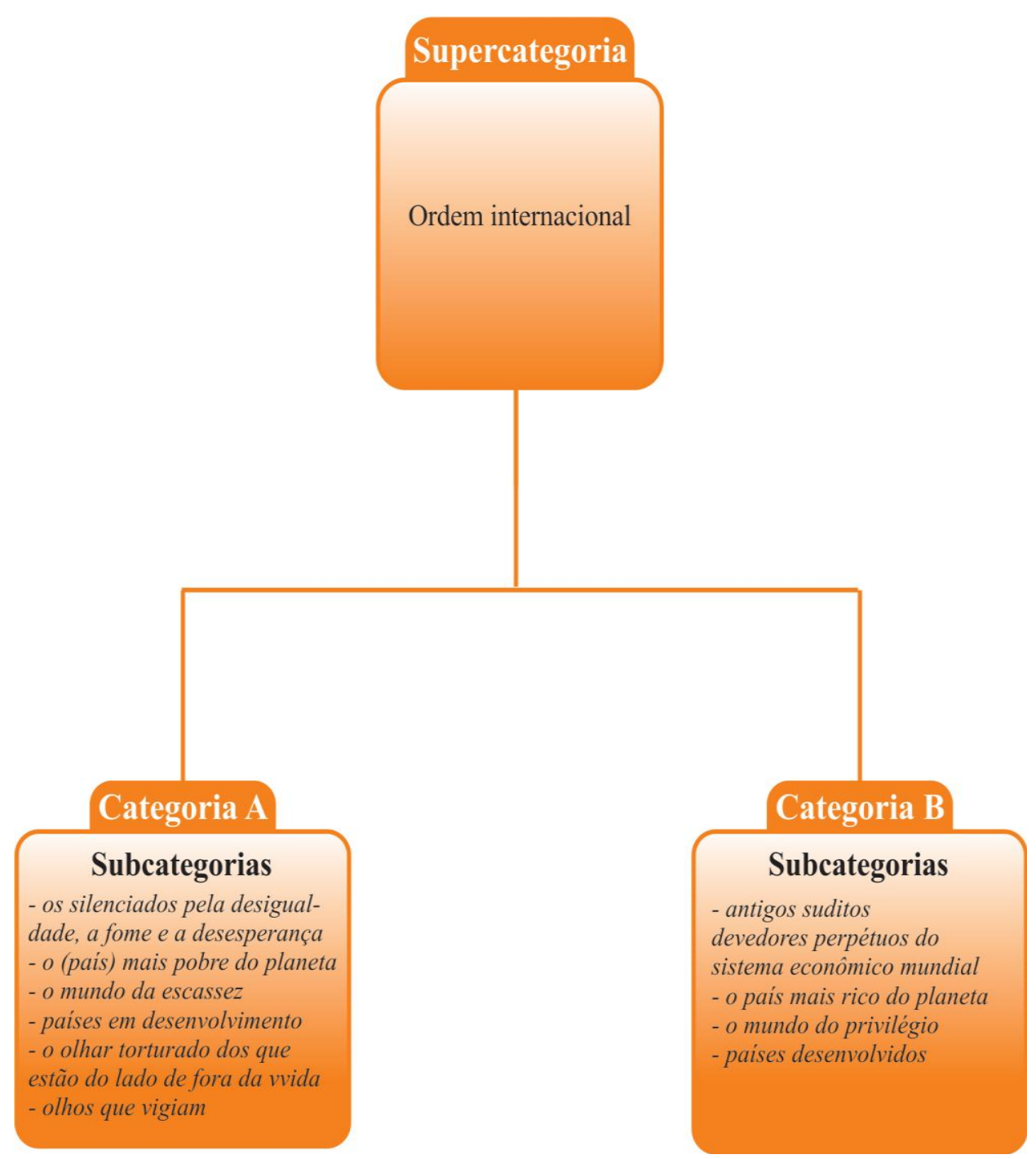

Figura 8. ONU, 2004: organização de categorias conforme a lógica dos contêineres 
Nos enunciados, metáforas estruturais viabilizaram a seleção de itens referenciais, constituídos por metáforas ontológicas e orientacionais. Entre essas ocorrências, destacamos que, no item 4.2.1.2, a parceria bilateral entre Brasil e Portugal apresentada em termos de construção, PARCERIA BILATERAL É CONSTRUÇÃO A DOIS, em (50), foi reforçada pela seleção "Vamos construir, agora, as pontes de uma nova cooperação, mais densa e madura", para indicar possibilidade de unir espaços distantes geograficamente. Por ela, é que se visualiza o resultado, a união entre os países, recuperando a ideia de atalho e o conceito da metáfora da jornada, utilizada de modo acentuado no pronunciamento. Este mesmo processo que permite que metáforas ontológicas e orientacionais reforcem mapeamentos mais complexos foi detectado em todos os discursos.

Importa-nos ressaltar, ainda, que muitos dos encaminhamentos dados nos pronunciamentos possibilitaram-nos depreender como se deu a orientação e a motivação retórica/argumentativa, no sentido de promover disposição para mudar determinado estado de coisas. Construções recorrentes de um cenário discursivo do presente e outro do futuro serviram como pistas do encaminhamento sugerido. A seguir, apresentamos dois esquemas (figuras 8 e 9), pelos quais ilustramos o modo como compreendemos terem ocorridos tais processos no item 4.1.2 (Davos, 2005). 


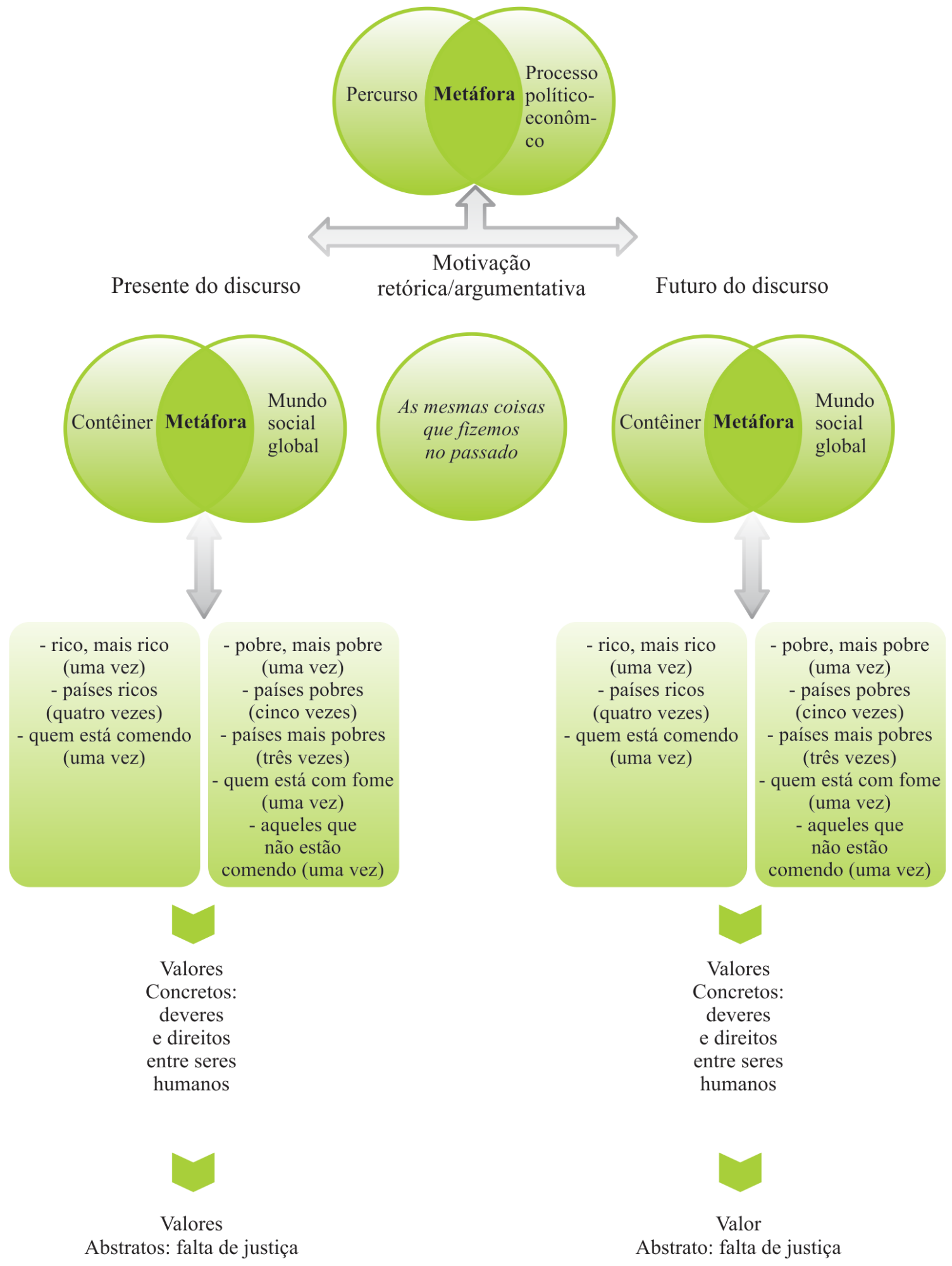

Figura 9. Davos, 2005: esquema argumentativo-referencial 1 
Presente do discurso

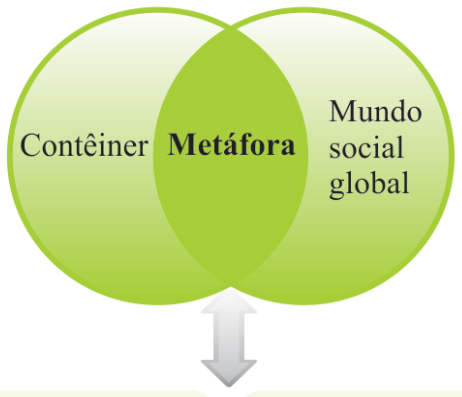

$$
\begin{gathered}
\text { - rico, mais rico } \\
\text { (uma vez) } \\
\text { - países ricos } \\
\text { (quatro vezes) }
\end{gathered}
$$

- quem está comendo (uma vez) (uma vez) (cinco vezes) (três vezes)
- pobre, mais pobre - países pobres - países mais pobres

- quem está com fome (uma vez) - aqueles que não estão comendo (uma vez)

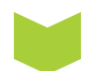

Valores

Concretos:

deveres

e direitos

entre seres

humanos

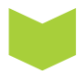

Valor

Abstrato: falta de justiça e de igualdade

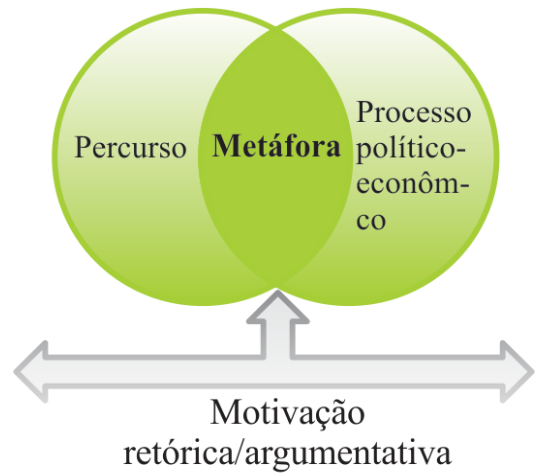

Futuro do discurso
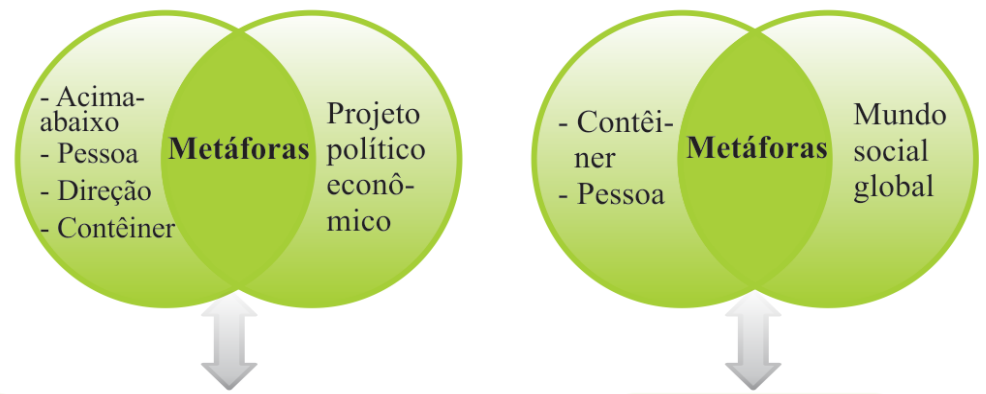

- um fundo

- um fundo sobre transações financeiras

- um fundo sobre

comércio mundial

- um fundo sobre o dinheiro que está nos chamados

'paraísos fiscais'

- uma coisa que fosse

substancialmente forte

- uma coisa que fosse dirigida aos países mais pobres

- coisas que pudessem dar

a certeza que daqui a 10 ,

15 ou 20 anos aquele país

que recebeu o auxílio

não seria mais um país

que precisasse ser ajudado

- um "fundo Lula",

- um "fundo Chirac",

- um "fundo Lagos"

- um "fundo Gordon Brown",

- a paternidade

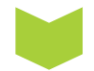

Valores

Concretos:

Abstrato: justiça social
Valor

mais justo, mais equânime e mais solidário.

- É esse o meu sonho - é esse o meu desejo

Valores

Concretos:

deveres

e direitos

entre seres

humanos; solidariedade,

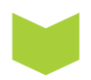
deveres e direitos

entre governantes e governados, pai e filho, responsabilidade. generosidade

Valor Abstrato: justiça social

Figura 10. Davos, 2005: esquema argumentativo-referencial 2 
Nas figuras 09 e 10, podemos depreender que cenários discursivos foram organizados de modo a conduzirem uma leitura específica do "hoje" e do "amanhã". Neste processo, a motivação recaiu sobre a necessidade de atitudes novas, para que resultados promissores fossem alcançados. Nesta direção, entendemos ter havido busca por conduzir o olhar do auditório para o que estaria em sua frente, conforme suas ações fossem mantidas ou alteradas. Salientamos que tal procedimento, passível de suscitar essa motivação, desenvolveu-se do mesmo modo em todos os pronunciamentos em que houve a proposta de mudança: relação entre um cenário discursivo do presente (como estava) e outro do futuro (o que se tornaria).

Além dessas observações, pudemos examinar que se utilizaram e associaram algumas especificidades de vários domínios-fonte, enquanto outras foram ocultadas. Este procedimento ocorreu em todos os itens e promoveu que se criasse um conjunto de qualificações, advindas de domínios distintos, mas que continham elementos comuns, os quais possibilitaram que se observasse coerência no discurso e que se conduzisse uma imagem singular da situação social, econômica e política em pauta. Em específico, no discurso proferido na ONU, item 4.1.3, entre as seleções lexicais que promoveram efeitos dessa ordem, destacamos: em (24), "o jugo de algumas poucas potências"; em (26), "Barreiras protecionistas e outros obstáculos", "Poderosa e onipresente, uma engrenagem invisível”, "a lógica que drena"; em (31), "o céu entre as grades", "a gaiola de ferro".

Tais formulações, por um lado, ativam informações específicas, por outro, levam a um mesmo conceito: o de falta de liberdade. A próxima ilustração (figura 11) apresenta como se deu esse processo: 


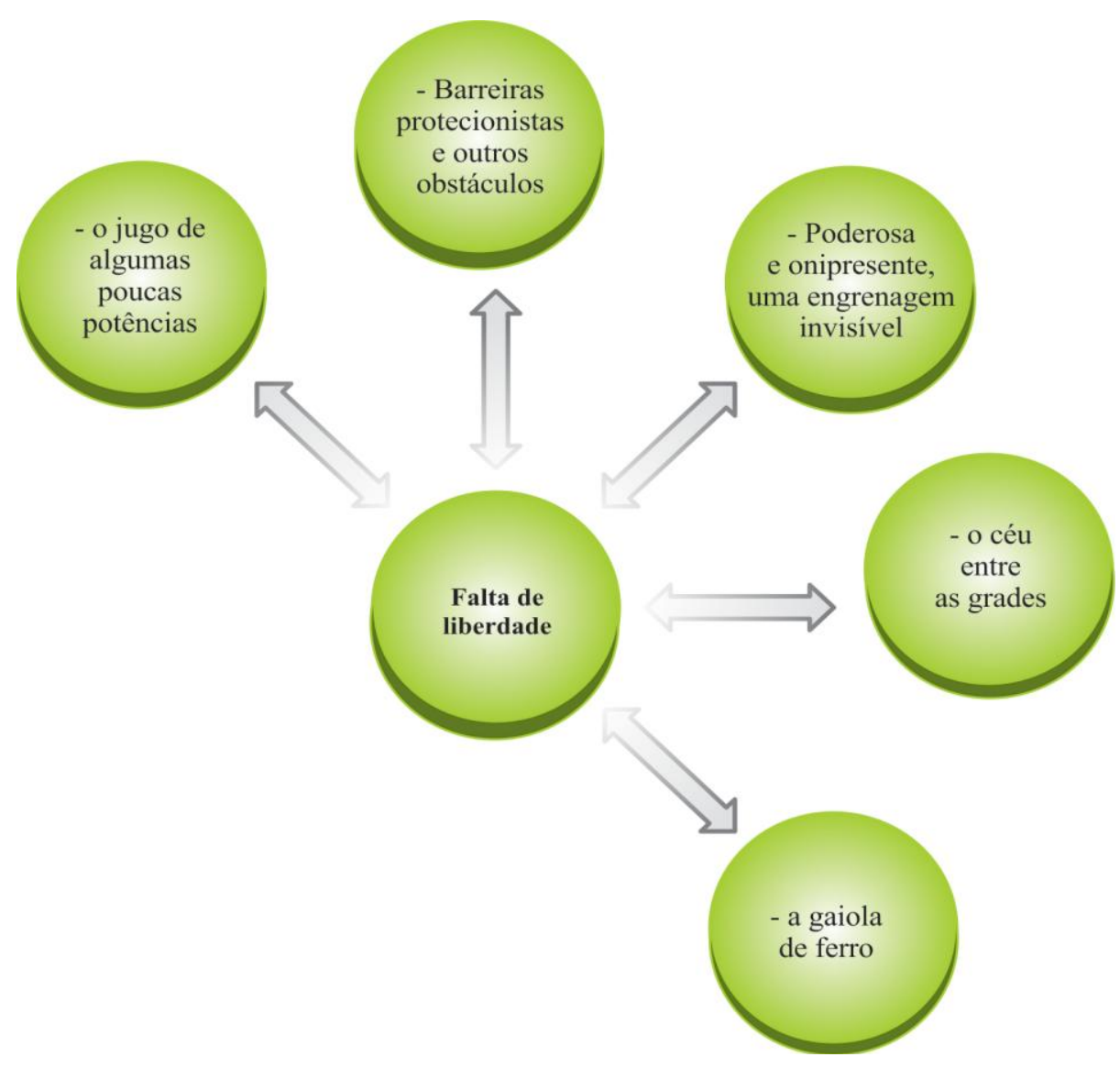

Figura 11. ONU, 2004: referenciação, metáfora e ativação de valor comum

No item 4.1.4 (China, 2004), a construção de uma ordem política internacional em termos de guerra e a formulação de redes referenciais advindas desse processo serviram-nos de pistas para detectar um modo específico de se constituir sentido metafórico na referenciação. As formulações do anexo 04, "dois terços da humanidade" (linhas 74-75), "milhões de pessoas" (linha 130), "os pobres do mundo" (linha 165), situam-se em um momento do discurso em que o domínio da guerra está ativado. Por tal razão, pode-se depreender sentido metafórico não nas seleções referenciais em si, mas a partir das informações que as rodeiam, em um processo de encaminhamento cognitivo. Assim é que, por exemplo, o termo "dois terços da humanidade" pode ser associado a "vítimas da guerra", uma vez que o cotexto permite tal inferência.

A respeito desse modo de se constituir sentido metafórico no discurso, diretamente ligado ao processo referencial, julgamos significativo recuperar o que dissemos à página 51, em consonância com Marcuschi (2007). Para este autor, há relação estreita entre referência e 
inferência, em razão de a explicitude corresponder a um dizer interpretável. Neste viés, quando se volta para a metáfora na referenciação, podemos entender a necessidade de um olhar além da rede referencial. O efeito metafórico corresponde ao produto de um diálogo entre orador e discurso e entre as várias seleções lexicais que, neste, são organizadas.

Nessa mesma direção, também examinamos haver papel referenciador nas formulações predicativas. Em vários momentos de nossa análise, deparamo-nos com procedimentos que recaíram sobre a ativação ou a retomada de um determinado objeto de discurso, seguido por verbos de essência de modo mais recorrente (definição) e alguns de estado: converter ("Os antigos súditos converteram-se em devedores perpétuos do sistema econômico internacional”, segmento 25, às linhas 25-27), estar ("Estamos perto de acabar a corrupção? Certamente que não, porque ela é uma coisa crônica, ela está incrustada, muitas vezes, na alma”, segmento 89, às linhas 283-284), deixar e passar (“para que Índia e Brasil deixem de ser países subdesenvolvidos ou países em desenvolvimento e passem a fazer parte do grupo privilegiado dos países ricos do planeta", segmento 61, às linhas 193-195). Posteriormente à seleção verbal, ocorrem caracterizações específicas, significativas para manter em foco a referência e criar sobre ela determinada imagem, sugerindo, por vezes, mudanças de categorias. Se deixássemos de observá-las, em razão dos propósitos deste trabalho, abdicaríamos de processos importantes da referenciação, apresentados no decorrer do discurso.

No caso da definição, que é uma maneira tradicional de observação da metáfora, entendemos que sua utilização permite que haja explicitude da associação de categorias pertencentes a domínios díspares, enfatizando a imagem que se quer construir. Retomemos os estudos de Glucksberg (2008), nos quais o autor observou a categorização metafórica a partir da relação de dois referentes textuais. Na formulação X é Y, o primeiro recebe algumas características do segundo, enquanto outras são desprezadas. Em nossas análises, em razão de esse procedimento ter sido recorrente, acreditamos no importante papel referencial das definições em termos de possibilitarem que se deem outras propriedades ao objeto de discurso em foco, delineando-o. Isto ocorreu, por exemplo, no segmento (51), em que a seleção “política e comércio exterior são uma via de duas mãos", à linha 187, anexo 04, trouxe a reativação de um objeto de discurso, ajustando-o à noção de jornada, gerando uma nova categorização.

Assim também ocorreu em (69), às linhas 110-123. O termo "Brasil" foi retomado, várias vezes, ganhando especificidades e categorizações pelo viés das definições: “o Brasil é 
um país que é o maior produtor e vendedor de suco de laranja do mundo; o Brasil é o maior vendedor de carne de frango do mundo; o Brasil é o maior vendedor de carne de boi [...] É esse país que quer se irmanar ao Quênia”. O encapsulamento selecionado, a partir do qual se torna evidente a personificação, permitiu que entendêssemos que as várias recategorizações dadas por meio da definição - que estabelece relação de objetos de discurso - cumpriam papel significativo para o delineamento da imagem do objeto de discurso em foco nesse segmento.

Em específico, nos discursos proferidos em encontros bilaterais, identificamos que o procedimento recaiu sobre a busca por semelhanças. Neste viés, nos itens 4.2.1.1, 4.2.1.2, 4.2.2.1, 4.2.3.1, os pronunciamentos foram delineados de modo a favorecer aproximação entre os países. Identificamos as seguintes metáforas, entendidas como centrais: RELAÇÃO BILATERAL BRASIL E PORTUGAL É VIAGEM MARÍTIMA A DOIS, RELAÇÃO BILATERAL BRASIL E PORTUGAL É JORNADA A DOIS, PARCERIA BILATERAL BRASIL E ÍNDIA É PEDRA PRECIOSA, PAÍS-PARCEIRO É UM GRÃO (Brasil e Quênia). O que há de similar em todas elas consiste na adequação ao auditório. Entendemos ter havido preocupação em utilizar informações culturais de cada local, como os símbolos. Mais do que isto, tais seleções promoveram encaminhamentos cognitivos e, consecutivamente, orientação argumentativa.

Já em relação ao pronunciamento feito em Brasília, cujo tópico voltou-se para a corrupção, o investimento foi direcionado à construção de uma imagem positiva pública do ex-presidente da República. A metáfora da guerra foi selecionada, primeiramente, imprimindo um cenário de luta contra a corrupção. O que se ativou a respeito desse domínio-fonte favoreceu que se delineassem características específicas sobre o então governo e o governante: força, persistência. Assim também, permitiu que se visualizasse o papel de Lula no cenário discursivo: guerreiro, defensor da coisa pública.

Interessa-nos, também, salientar que houve associação entre o domínio da política e o do corpo humano. Tal procedimento pode ser entendido como um modo de aproximar algo que está distante de muitos e conceituar corrupção, os políticos corruptos e os honestos. Retomemos algumas metáforas detectadas: GRUPO DO GOVERNO É UM CORPO, LULA É A CABEÇA DO CORPO, POLÍTICOS GOVERNISTAS SÃO PARTES DO CORPO, CORRUPÇÃO É UMA DOENÇA. Nesta acepção, os políticos corruptos correspondem às partes doentes do corpo, e os honestos, à saudável. 
Nesse encaminhamento, foi possível agir argumentativamente por meio do apelo à emoção, em que se evidenciou o sacrifício de Lula de ter de "cortar na própria carne", para defender a nação brasileira e estabelecer controle sobre a situação vista como problemática e imoral. Assim é que a seleção de metáforas favoreceu o encaminhamento cognitivo do discurso, em razão de cada qual, no momento em que foi utilizada, ter permitido constituir um elo entre as informações postas e criar cenário discursivo específico, assim como observamos ter ocorrido em todos segmentos examinados. 
No decorrer deste trabalho, procedemos à discussão de teorias que nos possibilitassem relacionar os três eixos centrais por nós propostos: Referenciação, Metáfora e Argumentação. A articulação desses estudos colaborou para que pudéssemos compreender os processos de construção de objetos de discurso em contextos situacionais, pertinentes à política internacional.

Em relação às especificidades dos pronunciamentos de Lula, temos que a atitude de discorrer sobre determinados tópicos, direcionando suas posições à questão da Justiça Social, e a de levar certos recortes enviesados de um estado de coisas à presença de auditórios complexos, em termos das características culturais que os compõem, podem ser consideradas estratégicas, em razão de terem permitido a construção da imagem de um Estado, de um governo e de um governante, aptos a assumirem mais participação nas decisões de ordem global.

Assim, ao observarmos os discursos, depreendemos a ênfase dada à justiça social e a outros subtópicos a ela relacionados (fome, pobreza, miséria, exclusão social etc.). Principalmente este tópico foi discutido por Lula nos encontros na ONU (2004), local em que se reúnem vários chefes de Estado com o intuito de discorrerem sobre questões voltadas à paz, à segurança e aos direitos humanos. Em outras reuniões, também houve tal evidência, como as ocorridas em Davos (2003, 2005), na China (2004), entre outras. Tudo indica que este procedimento se deveu às propostas da política externa do governo de Luiz Inácio Lula da Silva. O fato é que, nas relações exteriores e em sua política internacional, o discurso político desse governo revestiu-se da imagem tradicional do PT.

Nesse viés, acentuaram-se valores pertinentes à Carta de Direitos Humanos da ONU e a outros documentos internacionais, em que se inscrevem questões dessa ordem. Tais resultados levam-nos a crer que, embora não tenhamos tido como proposta central a observação das ideologias em específico, podemos dizer que as ocorrências de seleções lexicais, pelas quais se recorreu aos valores de um grupo global, são indicativas de ter havido apelo às ideologias dos órgãos internacionais e, também, como mencionamos, de um posicionamento ligado à vertente do Partido dos Trabalhadores (PT).

No início deste trabalho, propusemos a observação das metáforas utilizadas nos pronunciamentos selecionados e o exame de sua função em relação às teses defendidas. Neste sentido, nos discursos pronunciados em Davos (2003 e 2005), na ONU (2004) e na China 
(2004), cujos tópicos versaram sobre a justiça social, metáforas e referenciação entrelaçaramse e possibilitaram a apresentação de divisões entre seres humanos, convalidando a noção de haver injustiça no mundo global e, portanto, a necessidade de reformar e de construir uma nova ordem internacional. Examinamos a seleção de metáforas orientacionais, que promoveram a noção de dentro-fora, alto-baixo, tal como em "dos que vivem mergulhados no analfabetismo e na mais absoluta alienação" (Anexo 01, linhas 69-70), e a de ontológicas, permitindo que se visualizassem e se reforçassem características de agentes e de resultados, tal como ocorreu nas formulações (Anexo 3): "A falta de saneamento básico matou mais crianças na década passada do que todos os conflitos armados desde a Segunda Guerra" (linhas 40-41), “ O ódio e a insensatez que se alastram pelo mundo nutrem-se dessa desesperança, da absoluta falta de horizontes para grande parte dos povos" (linhas 43-44). Essas metáforas contribuíram para que se visualizasse um cenário impróprio e, assim, para que convalidasse as propostas sugeridas em termos, por exemplo, de reforma.

Assim é que metáforas estruturais como essas (reforma e construção), selecionadas para a apresentação de propostas políticas, foram reforçadas pelas orientacionais e pelas ontológicas, na medida em que estas propiciaram a visualização de um mundo desigual e, consecutivamente, deram força às teses relacionadas à necessidade de mudança de postura dos líderes mundiais. Salientamos que tal processo que permite que esses dois últimos tipos de metáforas reforcem mapeamentos mais complexos foi detectado em todos os pronunciamentos examinados.

Observamos que a função argumentativa das metáforas selecionadas nos pronunciamentos feitos em Davos (2003 e 2005), na ONU (2004) e na China (2004) também correspondeu à possibilidade de se recorrer a acusações indiretas. Neste viés, temos que o orador se distancia de alguma culpabilidade. Pela metáfora, inferiu-se, não se explicitou. Entendemos que, em alguns momentos, houve críticas veladas, que fortaleceram a argumentação, uma vez que o ataque direto poderia levar a resultados negativos na política internacional.

Já outros procedimentos recaíram sobre a vantagem de se fazer parceria com o Brasil. Esta observação consistiu em outra especificidade dos pronunciamentos de Lula, em razão de a busca por parceiros estratégicos ter sido uma das propostas mais importantes de seu governo, em termos de alcançar mais participação nas relações políticas e comerciais no mundo. As seleções lexicais que examinamos, em cada etapa do discurso, deram a conhecer a 
argumentação utilizada para alcançar tal propósito. A referenciação metafórica teve como embasamento a estratégia de relação entre grupos, trazendo à tona o que era comum, tal como a seleção de símbolos patrióticos de cada país, permitindo também que outro procedimento argumentativo estivesse em jogo, que foi o da emoção, de modo que pudesse suscitar o efeito de "soar certo". Além do mais, foi por meio da utilização de metáforas estruturais, por diversas vezes, inter-relacionadas que se puderam constituir cenários discursivos, nos quais a noção de ação conjunta foi acentuada.

Nessa direção, encaminharam-se as imagens dos agentes-países em situação de viagem (RELAÇÃO BILATERAL BRASIL E PORTUGAL É VIAGEM MARÍTIMA A DOIS), de jornada e da construção (RELAÇÃO BILATERAL BRASIL E PORTUGAL É JORNADA A DOIS, PARCERIA BILATERAL É CONSTRUÇÃO A DOIS), de garimpo (PARCERIA BILATERAL BRASIL E ÍNDIA É PEDRA PRECIOSA), do ditado popular “Comer de grão em grão" (PAÍS-PARCEIRO É UM GRÃO).

Observamos que o papel referenciador da metáfora correspondeu também à atitude de possibilitar a utilização de domínios-fonte, pertinentes ao conhecimento específico de cada auditório. Tal resultado convalida o pressuposto de a metáfora e a referenciação poderem ser estratégias da argumentação, na medida em que foram selecionadas, tendo em vista as características específicas de cada auditório, promovendo articulações coesivas que davam condições para que houvesse uma compreensão específica do discurso (docere).

Mais do que isso, examinamos que não houve, de modo geral, a presença de uma única metáfora, pela qual se constituíam redes referenciais sistematizadas, mas houve interrelação de domínios-fonte a um determinado domínio-alvo. Nesta direção, embora tenhamos observado, por exemplo, em Portugal (2005), a presença da metáfora da jornada (RELAÇÃO BILATERAL BRASIL E PORTUGAL É JORNADA A DOIS), temos que o domínio da construção (PARCERIA BILATERAL É CONSTRUÇÃO A DOIS) permitiu que se desse outros atributos à parceria. $\mathrm{O}$ mesmo ocorreu no pronunciamento dirigido a políticos e a empresários do Quênia.

Na Índia, em uma etapa do discurso, selecionaram-se O MUNDO GLOBAL DE NEGÓCIOS É UM GRANDE GARIMPO, PARCERIA BILATERAL É PEDRA PRECIOSA. Posteriormente, identificamos outras metáforas que também reforçaram a tese de se unir com países, geograficamente distantes, para se incluir (noção de inclusão e de 
exclusão) no comércio internacional, de modo a desconcentrar o poder econômico, tal como: "O Brasil se orgulha de poder ser a porta de entrada da Índia na América do Sul e no Mercosul" (Anexo 7, às linhas 125-126). Ocorreram, portanto, metáforas centrais articuladas e inseridas em um mesmo fio condutor de sentido.

No pronunciamento feito em Brasília, observamos, primeiramente, a seleção da metáfora da guerra, imprimindo um cenário em que governo e governante lutavam contra a corrupção, fortalecendo a imagem do orador, na medida em que ele foi apresentado como guerreiro, defensor da coisa pública. Em seguida, examinamos a associação feita entre o domínio da política e do corpo humano. Entre as metáforas observadas, destacamos o seguinte encaminhamento dado no discurso: GRUPO DE PETISTAS É UM CORPO, LULA É A CABEÇA DO CORPO; GOVERNO É UM CORPO, POLÍTICOS GOVERNISTAS SÃO PARTES DO CORPO, CORRUPÇÃO É UMA DOENÇA. Entendemos que o investimento recaiu sobre a proposta de Lula de "cortar na própria carne" em favor do bem viver da sociedade brasileira. Quando esse orador apresentou tal afirmação, pode-se dizer que ele recorreu à estratégia argumentativa de excluir determinados membros, cujas atitudes não se coadunavam com a proposta grupal, do governo. Nesta direção, enunciar a incompatibilidade de alguns é um modo de buscar a manutenção de uma imagem pública positiva dos outros políticos petistas e governistas e, principalmente, a de Lula.

Já em relação ao exame das redes referenciais relacionadas às metáforas detectadas nos pronunciamentos, segundo objetivo de nosso trabalho, entendemos que foi nesse processo de inter-relacionar metáforas que se promoveram categorizações e recategorizações. $\mathrm{Na}$ medida em que um domínio-fonte estava em foco, objetos de discurso foram delineados de modo que algumas propriedades fossem evidenciadas e outras desconsideradas. Quando outro domínio estava em evidência, consecutivamente, outras atribuições eram selecionadas na rede referencial.

Nesse sentido, no pronunciamento feito no Quênia, a metáfora, oriunda do ditado popular "De grão em grão, a galinha enche o papo", permitiu-nos depreender a associação ALGUNS PAÍSES EM DESENVOLVIMENTO É UM GRÃO, dando à questão econômica de alguns países, a noção de tamanho (grande vs. pequeno). Na sequência, metáforas ontológicas, por um lado, garantiram manutenção dessas relações, reforçando as características apresentadas: “cada país, por menor que seja”, "grandes países”. Neste viés, 
em cada etapa do discurso, domínios-fonte estruturaram e delinearam objetos de discurso, sem desprezarmos o fato de os primeiros terem sido selecionados de modo estratégico.

Ainda em relação às (re)categorizações examinadas, entendemos que estas, promovidas nas redes referenciais, foram constituindo os cenários discursivos de cada pronunciamento, reforçando o sentido metafórico, de modo que a situação construída levasse a ideia de mudar, de agir, de aceitar a tese desenvolvida. Foram, ao mesmo tempo, recursos coesivos e argumentativos, sociocognitivos e discursivos.

O modo de organizar um cenário discursivamente, compreendido como uma atitude não fixa, mas efetivada para fins específicos em situações diversas, deu-se em razão de haver lógicas subjacentes, correspondentes à noção de agrupamento (contêiner). Assim é que se pode unir determinados objetos de discurso a partir das categorias a eles propostas e criar situações enviesadas axiologicamente, por meio de seleções lexicais específicas.

Além do mais, a ação de categorizar e recategorizar permitiu a construção de cenários discursivos repletos de valores. Estes, tido como importantes objetos de acordo pelos autores da Nova Retórica (Perelman e Olbrechts-Tyteca, 2002 [1958]), mereceram atenção especial em nosso trabalho. Observamos que a metáfora, nos processos referenciais, colaborou para que se aproximassem do auditório conceitos abstratos, de difícil compreensão, por meio dos valores concretos advindos de alguns domínios-fonte, tais como o de família, o de governança, o de geografia etc., que propiciaram a ativação dos direitos e dos deveres de certas entidades, para que se entendessem e se construíssem visões sobre o que é liberdade, igualdade e justiça.

Em relação ao terceiro objetivo específico apresentado no início deste trabalho correspondente ao exame do encaminhamento argumentativo efetivado a partir da articulação das redes referenciais metafóricas - pudemos detectar que o modo como os discursos foram conduzidos possibilitou uma orientação e uma motivação retórica/argumentativa, no sentido de promover disposição no auditório para que este aceitasse a tese enunciada. Entre os procedimentos examinados, a construção de cenários discursivos da situação social-política presente e outros de um futuro promissor ou não serviu (Cf. figuras 09 e 10) como pista do encaminhamento privilegiado.

Além do mais, observamos que foram utilizadas e associadas especificidades de vários domínios-fonte, no desenvolvimento do pronunciamento, enquanto outras foram ocultadas. 
Isto possibilitou que se criasse um conjunto de qualificações de alguns objetos de discurso ativados, que advinham de domínios diferentes, mas que continham elementos comuns, reforçando determinada imagem dos referentes no discurso e orientando argumentativamente, em razão de reforçarem as teses enunciadas. A figura 11 (página 251) ilustra tal observação, uma vez que os objetos de discurso ativados levaram à ideia de falta de liberdade; procedimento utilizado para convalidar a noção de concentração do comércio internacional e para indicar a necessidade de os países unirem-se e fortalecerem-se.

Assim também, depreendemos que o momento em que a metáfora foi selecionada correspondeu a um fator significativo para o encaminhamento argumentativo do discurso. No pronunciamento feito na China (2004), várias formulações lexicais com função referencial ("os pobres do mundo", "dois terços da humanidade", entre outras) foram apresentadas, quando estava em foco o domínio-fonte da guerra. Esta organização permite que se crie sentido metafórico a essas formulações (os pobres do mundo $\rightarrow$ vítimas da guerra), caso haja inferência por parte do auditório, fortalecendo a argumentação, no sentido de apelar à emoção.

Ainda em relação ao encaminhamento argumentativo, entendemos que as redes referenciais e metafóricas, a partir do modo como foram elaboradas e organizadas, propiciaram que se reforçassem alguns valores pertinentes aos direitos humanos. Foi no desenvolvimento de alguns discursos (Davos, 2003, 2005; ONU, 2004, China, 2004) que se orientou uma noção de justiça social, de igualdade a partir de experiências concretas, utilizando-se, assim, da argumentação ligada à regra da justiça (Perelman e Olbrechts-Tyteca, 2002 [1958]). A partir do exposto, entendemos que nossa hipótese se confirma. 


\section{REFERÊNCIAS BIBLIOGRÁFICAS}




\section{Referências bibliográficas}

ALMEIDA, P. R. de (2003). A política internacional do Partido dos Trabalhadores: da fundação à diplomacia do governo Lula. Revista de Sociologia e Política, n. 20, Brasília, Instituto Brasileiro de Relações Internacionais, p.87-102.

(2004). Uma política externa engajada: a diplomacia do governo Lula. Revista Brasileira de Política Internacional, Brasília, Instituto Brasileiro de Relações Internacionais, v.47, n.1, p.162-184.

(2006). Uma nova 'arquitetura' diplomática? - Interpretações divergentes sobre a política externa do governo Lula (2003-2006). Revista Brasileira de Política Internacional, Brasília, Instituto Brasileiro de Relações Internacionais, v.49, n.1, p.95-116.

(2012). A diplomacia do governo Lula: balanço e avaliação. Revista Política Externa, São Paulo, HMG Editora, v.20, n.3, p.95-114.

ALBUQUERQUE, J. A. G. (2005). Relações internacionais contemporâneas: a ordem mundial depois da guerra fria. Petrópolis: Vozes.

APOTHÉLOZ, D. (2003). Papel e funcionamento da anáfora na dinâmica textual. In. CAVAlCANTE, M. M.; RODRIGUES, B.B.; CIULLA, A. (Org.). Clássicos da Linguística 1. Referenciação. São Paulo: Contexto, p.53-84.

APOTHÉLOZ \& REICHLER-BÉGUELIN, M. J. (1995). Construcion de la référence et stratégies de designation. In: BERRENDONNER, A.; REICHLER-BÉGUELIN, M. J. (Eds.). Du sintagme nominal aux objets-de-discours: SN complexes, nominalisations, anaphors. Neuchâtel: Instituto de Linguística da Universidade de Neuchâtel, p. 227-271.

AQUINO, Z. G. O. de (1997). Conversação e conflito: um estudo das estratégias discursivas em interações polêmicas. Vol. I e II. Tese de Doutoramento. São Paulo: Universidade de São Paulo.

. (2003). O léxico no discurso político. In: PRETI, D. (Org.). Léxico na língua oral e na escrita. São Paulo: Humanitas, p.195-210.

. (2005). Reflexões sobre a argumentação no discurso político. In: SILVA, L. A. da (Org.). A língua que Falamos - Introdução ao Estudo da Língua Portuguesa. Português: História, Variação e Discurso. São Paulo: Globo, p.105-119.

BALLY, C. (1951). Traité de stylistique française. 3. ed. Paris-Genebra: KlincksieckGeorg.

BENVENISTE, E. (1976). Problemas de lingüística geral. São Paulo: Companhia Editora Nacional/ Editora da Universidade de São Paulo.

BLACK, M. (1962). Metaphor. In: BLACK, M. (Org.). Models and metaphor. New York: Cornell University Press. 
BOLIVAR, A. (2008). Cachorro de imperio" versus "Cachorro de Fidel": los insultos em la política latinoamericana. Discurso \& Sociedad, Revista Multidisciplinaria de Internet, v.2, n. 1, p. 01-38.

BRASIL. Ministério das Relações Exteriores. Brasília. Palácio do Itamaraty, Esplanada dos Ministérios. Disponível em: < http://www.itamaraty.gov.br/>. Acesso em: 26 jan. 2010.

BRASIL. ONUBR - Nações Unidas no Brasil. Brasília. Disponível em: < http://www.onu.org.br/onu-no-brasil/onu-no-brasil/>. Acesso em: 26 jan. 2010.

BRASIL. Presidência da República. Manual de redação da Presidência da República. 2. ed. rev. e atual. Brasília, Presidência da República, 2002. Disponível em: http://www.planalto.gov.br/ccivil_03/manual/ManualRedPR2aEd.PDF>. Acesso em: 26 ago. 2010.

BRASIL. Portal Oficial da Presidência da República. Constituição da República Federativa do Brasil de 1967. Brasília, Casa Civil, Subchefia para Assuntos Jurídicos, 1967. Disponível em: < http://www.planalto.gov.br/ccivil_03/constituicao/constitui\%C3\%A7ao67.htm>. Acesso em: 26 ago. 2010.

BRASIL. Portal Oficial da Presidência da República. Discursos do presidente da República. Brasília. Disponível em: < http://www2.planalto.gov.br/imprensa/discursos>. Acesso em: 15 jan. 2010.

BOUSOÑO, C. (1970). Teoría de la expresión poética. 5. ed. Madri: Gredos.

CEREJA, W. (2007). Significação e Tema. In: BRAIT. B. (Org). Bakhtin. Conceitos-Chave. São Paulo: Contexto. p.201-223.

CAVALCANTE, Mônica Magalhães; KOCH, Ingedore G. Villaça. (2007). A acessibilidade de referentes no discurso. In: CAVALCANTE, Mônica Magalhães; COSTA, Maria Helenica Araújo; JAGUARIBE, Vicência Freitas; FILHO, Valdinar Custódio. (Orgs.). Texto e discurso sob múltiplos olhares. Referenciação e outros domínios discursivos. Rio de Janeiro: Lucerna. p. 9-39.

CHARAUDEAU, P. (2006). Discurso político. Tradução de Dilson Ferreira da Cruz e Fabiana Komesu. São Paulo: Contexto.

CHARTERIS-BLACK, J. (2006). Britain as a container: immigration metaphors in the 2005 election campaign. Discourse \& Society, Londres, v.17, n. 05, p.563-581.

Routledge.

(2007). The communication of leadership: the design of leadership style. New York:

(2008). Metaphors as Models of Political Leadership. University of Durham.

Disponível em: <http://www.dur.ac.uk/resources/mlac/research/metaphors_as_models/ Charteris2.pdf $>$. Acesso em: 28 de maio de 2009. 
CHARTERIS-BLACK， J. (2009). Gran Bretaña como contenedor: metáforas sobre inmigración en la campaña electoral de 2005. Traduzido por María de las Mercedes Luciani y Ailén Heredia. Discurso e Sociedad, Surrey, v.3, p.467-494.

(2011). Politicians and rhetoric: the persuasive power of metaphor. Basingstoke:

Palgrave Macmillan.

CHILTON, P. A. (2004). Analysing political discourse. United Kingdon: Routledge.

. (1996). Security Metaphors. Cold War Discourse from Containment to Common House. New York: Peter Lang.

CHILTON, P.; SCHÃFFNER, C. (2002). Politics as text and talk: analytic approaches to political discourse. Amsterdam: John Benjamins.

CONTE, M. E. (2003). Encapsulamento anafórico. In. CAVALCANTE, M. M.; RODRIGUES, B.B.; CIULlA, A. (Org.). Clássicos da Linguística 1. Referenciação. São Paulo: Contexto, p. 177-190.

CORNISH, F. (1999). Anaphora, Discourse, and Understanding: evidence from english and french. New York: Oxford University Press.

CONSTEN, M.; KNEES, M. (2008). Complex anaphors in discourse. In: BENZ, A.; KUNHLEIN, P. (Ed.). Constraints in discourse. Philadelphia: Jonh Benjamins B.V. p. 181200.

FAUCONNIER, G., TURNER, M. (2003). The way we think. New York: Basic Books.

FRANCIS, G. (1994). Labelling discourse: an aspect of nominal-group lexical cohesion. In: COULTHARD, M. (Ed.). Advances in written text analysis. Londres: Routledge. p.83-101.

GEERTZ, C. (1989). A interpretação das culturas. Rio de Janeiro: Livros Técnicos e Científicos Editora.

GIBBS, R. W. (1994). The Poetics of Mind Figurative Thought: Language and Understanding. New York: Cambridge University Press.

(1999). Taking metaphor out of our heads and putting it into the cultural world. In:

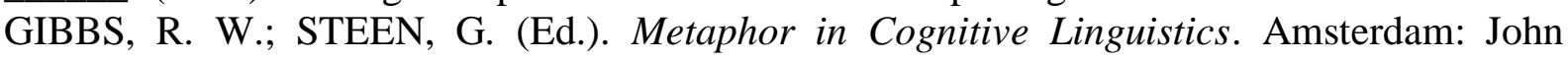
Benjamins. p.145-166.

(2006). Cognitive linguistics and metaphor research: past successes, skepticalquestions, future challenges. DELTA, São Paulo, v. 22, n. especial, p. 01-20.

GLUCKSBERG, S. (2008). How metaphors create categories. In: GIBBS, R. (Org.). The handbook of metaphor and thought. Cambridge: Cambridge University Press, p.67-83. 
GONZÁLEZ RUIZ, R. (2009). Algunas notas en torno a un mecanismo de cohesión textual: la anáfora conceptual. In: PENAS, M. A.; GONZÁLEZ, R. (Eds.). Estudios sobre el texto. Nuevos enfoques y propuestas. Frankfurt: Peter Lang, p.247-278.

GUIMARÃES, E. (1999). Figuras de retórica e argumentação. In. MOSCA, L. L. S. (Org.). Retóricas de ontem e de hoje. São Paulo: Humanitas, p. 145-160.

HERMANN, C. F. (1990). Changing course: when governments choose to redirect foreign policy. International Studies Quarterly, v. 34, n. 1, p. 3-21.

KOCH, I. V. (1996). Argumentação e linguagem. 9. ed. São Paulo: Cortez.

(2001). A referenciação como atividade cognitivo-discursiva e interacional. In: II Congresso Internacional da Abralin. Boletim da Associação Brasileira de Linguística, Fortaleza, v. 26, número especial, p. 81-84.

. (2005a). Referenciação e orientação argumentativa. In. KOCH, I., V.; MORATO, E. M.; BENTES A. C. (Org.). Referenciação e Discurso. São Paulo: Contexto, p. 33-52.

.(2005b). A construção dos sentidos nos discursos: uma abordagem sociocognitiva. Revista Investigações, Universidade Federal de Pernambuco, v.18, n.2. Disponível em: $<$ http://www.revistainvestigacoes.com.br/volumes/vol.18.n.2_2005_artigosweb/Ingedorekoch _a-construcao-dos-sentidos_vol18-n2_art01.pdf>. Acesso em: 29 de outubro de 2009.

.(2006). Desvendando os segredos do texto. 5. ed. São Paulo: Cortez.

(2008a). Como se constroem e reconstroem objetos de discurso. Revista Investigações, Campinas, v.21, n.2, p.99-114. Disponível em: <http://www.ufpe.br/pgletras/Investigacoes/Volumes/Vol.21.2/Ingedore_Koch.pdf>. Acesso em 10 de abril de 2009.

.(2008b). Léxico e progressão referencial. Estudos em Homenagem ao Professor Mario Vilela, Faculdade de Letras, Universidade do Porto, v. 1, p.263-275. Disponível em: <http://ler.letras.up.pt/uploads/ficheiros/4564.pdf>. Acesso em 10 de abril de 2009.

KOCH, I. V.; MARCUSCHI, L. A. (1998). Processos de referenciação na produção discursiva. DELTA, São Paulo, v. 14, número especial, p. 169-190.

KÖVECSES, Z. (2002). Metaphor: a practical introduction. New York: Oxford University Press.

(2003). Metaphor and emotion: language, culture, and body in human feeling. Cambridge: Cambridge University Press.

. (2005). Metaphor and culture. Universality and variation. Cambridge: Cambridge University Press. 
KÖVECSES, Z. (2009). The effect of context on the use of metaphor in discourse. Ibérica, Castelló, n.17, p.11-24.

(2010). Metaphor: a practical introduction. 2. ed. New York: OUP. HÁ O DE 2003.

LAKOFF, G. (1977). Linguistic Gestalts. In: Papers from the Thirteenth Regional Meeting of the Chicago Linguistics Society. Chicago: Illinois, p.236-287.

. (1987). Women fire and dangerous things: what categories reveal about the mind.

Chicago: University of Chicago Press.

(1993). The contemporary theory of metaphor. In: ORTONY, A. (Ed.). Metaphor and Thought. Cambridge: CUP, p.202-252.

. (2002). Moral Politics. Chicago: University of Chicago Press.

. (2011). Retaking Political Discourse (Palestra). Disponível em: http://www.youtube.com/watch?v=UseIJAIxR-4. Acesso em 20 nov. 2012.

LAKOFF, G.; JOHNSON, M. (1980). Metaphors We Live By. Chicago: Chicago University Press.

; _ (1999). Philosophy in the flesh. The embodied mind and its challenge to western thought. New York: Basic Book.

; __ (2003). Metaphors we live by. In: POTTER, J. (Org.). Representing Reality: Discourse, Rhetoric and Social Construction. London: Sage Publications Ltd. p.124-132.

LEITE, R. L. (2007). Da recategorização metafórica à metaforização textual. In: CAVAlCANTE, M. M.; COSTA, M. H. A.; JAGUARIBE, V. F.; FILHO, V. C. (Orgs.). Texto e discurso sob múltiplos olhares. Referenciação e outros domínios discursivos. Rio de Janeiro: Lucerna. p.104-122.

LIMA, S. M. C. de. (2007). Recategorização metafórica e humor: uma proposta classificatória. In: CAVALCANTE, M. M.; COSTA, M. H. A.; JAGUARIBE, V. F.; FILHO, V. C. (Orgs.). Texto e discurso sob múltiplos olhares. Referenciação e outros domínios discursivos. Rio de Janeiro: Lucerna. p.74-103.

MARCUSCHI, L. A. (2001a). Atos de referenciação na interação face a face. Boletim da Associação Brasileira de Linguística, II Congresso Internacional da ABRALIN, Fortaleza, v. 26, número especial, p. 71-77.

. (2001b). Da fala para a escrita. Atividades de retextualização. São Paulo: Cortez.

. (2001c). Aspectos da questão metodológica na análise verbal: o continuum quantitativo-qualitativo. Revista da Aled, v.1, n. 1, p. 23-42. 
MARCUSCHI, L. A. (2002). Do código para a cognição: o processo referencial como atividade criativa. Veredas, Juiz de Fora, v. 6, n.1, p. 43-62.

(2004). O léxico: lista, rede ou cognição social?. In: NEGRI, L.; FOLTRAN, M. J.; OLIVEIRA, R. P. de (Org.). Sentido e Significação: em torno da obra de Rodolfo Ilari. São Paulo: Contexto, p. 263-284.

(2005). A construção do mobiliário do mundo e da mente: linguagem, cultura e categorização. In: MIRANDA, N. S.; NAME, M. C. (Orgs.). Linguística e Cognição. Juiz de Fora: Editora UFJF. p.49-77.

. (2007). Cognição, linguagem e práticas interacionais. Rio de Janeiro: Lucerna.

. (2008). Produção textual, análise de gêneros e compreensão. São Paulo: Parábola.

MONDADA, L. (2001). Gestion du Topic e organization de la conversation. Cadernos de Estudos Linguísticos, Campinas, v. 41, p. 7-36.

. (2002). Cognition et parole-en-interaction. Veredas, Juiz de Fora, v. 6, n. 1, p. 9-27.

. (2005a). A Referência como trabalho interativo: a construção da visibilidade do detalhe anatômico durante uma operação cirúrgica. In. KOCH, I., V.; MORATO, E. M.; BENTES A. C. (Org.). Referenciação e Discurso. São Paulo: Contexto. p.11-31.

(2005b). L'exploitation située de ressources langagières et multimodales dans la conception collective d'une exposition. In. LAURENT, F.; BRONCKART, J. P. (Org.). L'Analyse des actions et des discours en situation de travail: concepts, methods et applications. Louvain-la-Neuve: Peers. p. 135-154.

MONDADA, L.; DUBOIS, D. (2003). Construção dos objetos de discurso e categorização: Uma abordagem dos processos de referenciação. In. CAVALCANTE, M. M.; RODRIGUES, B.B.; CIULLA, A. (Org.). Clássicos da Linguística 1. Referenciação. São Paulo: Contexto. p. 17-52.

MONTERO, M. (2009). Poder y Palabra: Mentira Implícita y Accidentes en Discursos Presidenciales. Discurso e Sociedad, v. 3, p. 348-371.

MORATO, E. M. (2005). Aspectos sócio-cognitivos da atividade referencial: as expressões formulaicas. In: MIRANDA, N. S.; NAME, M. C. (Orgs.). Linguística e Cognição. Juiz de Fora: Editora UFJF. p.79-94.

MORATO, E. M.; KOCH, I. G. V. (2007). Acessibilidade de referentes no discurso. In: CAVAlCANTE, M. M.; COSTA, M. H. A.; JAGUARIBE, V. F.; FILHO, V. C. (Orgs.). Texto e discurso sob múltiplos olhares. Referenciação e outros domínios discursivos. Rio de Janeiro: Lucerna. p. 09-39. 
MORENO, M. A. (2008). Metaphors in Hugo Chávez's Political Discourse: Conceptualizing Nation, Revolution and Opposition. Tese de Doutorado. New York: The City University of New York.

MUSOLFF, A. (2004). Metaphor and political discourse: Analogical reasoning in debates about Europe. Basingstoke: Palgrave Macmillan.

(2006). Metaphor scenarios in the public discourse. Metaphor and Symbol, United Kingdom, v.21, n.02, p.23-38.

O'BRIEN, G.V. (2003). Indigestible Food, Conquering Hordes, and Waste Materials: Metaphors of Immigrants and the Early Immigration Restriction Debate in the United States. Metaphor \& Symbol, Lawrence Erlbaum, v.18(1), p. 33-47.

O'BRIEN, J. (2010). The Production of Reality: Essays and Readings on Social Interaction. 5. ed. Califórnia: Sage Publications.

PALUMBO, R. (2008). Referenciação e Argumentação: a dinâmica nas orientações argumentativas em debates políticos televisivos. Dissertação de Mestrado. São Paulo: Universidade de São Paulo.

(2010). A metáfora da guerra nos discursos de Lula: um estudo sobre os processos referenciais e argumentativos. Revista Intercâmbio, v. 21. São Paulo: LAEL/PUC-SP, p.7897.

(2011). O olhar disciplinador nas notícias online: um enfoque argumentativo. Anais do SILEL, Uberlândia, UDUFU, Universidade Federal de Uberlândia, v.2, n.2. Disponível em: <www.ileel.ufu.br/anaisdosilel/pt/arquivos/silel2011/364.pdf>. Acesso em 22 jan. 2012.

PAULHAN, J. (1930). Lê guerrier appliqué. Paris: Gallirmard.

PERELMAN, C.; OLBRECHTS-TYTECA, L. (2002 [1958]). Tratado da argumentação. A Nova Retórica. Tradução Maria Ermantina Galvão. São Paulo: Martins Fontes.

PRETI, D. (Org.). (2005). O discurso oral culto. 3. ed. São Paulo: Humanitas.

PINKER, S. (2004). Tábula rasa - A negação contemporânea da natureza humana. São Paulo: Companhia das Letras.

REDDY, M. (1979). The Conduit Metaphor: a Case of Frame Conflict in our Language about Language. In: ORTONY, A. (Ed.). Metaphor and Thought. Cambridge: Cambridge University Press.

RICOEUR, P. (2005 [1975]). A Metáfora Viva. 2. ed. Tradução de Dion Davi Macedo. São Paulo: Edições Loyola.

RICHARDS, I. A. (1936). The Philosophy of Rhetoric. Oxford: Oxford University Press. 
RONCARATI, C. (2010). As cadeias do texto. Construindo sentidos. São Paulo: Parábola.

SILVA, L. S. (2008). A metáfora conceptual na construção do discurso jornalístico. Dissertação de Mestrado. São Paulo: Universidade Católica de São Paulo, PUC-SP.

SKIRL, H. (2007). Metaphorical anaphors. In: SCHWARZ-FRIESE, M.; CONSTEN, M.; KNEES, M. Anaphors in text: cognitive, formal e applied approaches to anaphoric reference. Philadelphia: John Benjamins Publishing Company. p.103-120.

SOUZA, A. (2010). Retórica, cognição e desejo: o que nos leva a agir. In: SILVA, A. S. da; MARTINS, J. C.; MAGALHÃES, L; GONÇALVES, M. Comunicação, cognição, média. v.2. Braga: Universidade Católica Portuguesa, Faculdade de Filosofia. p.813-824.

SCHWARZ, M. (2000). Indirekte Anaphern in Texten. Tübingen: Niemeyer.

TEUBERT, W. (2010). Meaning, Discourse and Society. Cambrigde: Cambrigde University Press.

TUPYNAMBÁ, G. C. (2010). A construção das imagens de si e do país em discursos internacionais do presidente Lula em 2003. Dissertação de Mestrado. Brasília: Universidade de Brasília.

VAN DIJK, T. A. (2003). Ideologia y discurso. Una introducción multidisciplinaria. Barcelona: Ariel.

(2004a). Politics, ideology and discourse. In: WODAK, R. (Ed.). Language and Politics. Encyclopedia of language and linguistics. Disponível em: <http://www.discourse-insociety.org/teun.html>. Acesso em: 10 maio 2005.

(2004b). Ideology and discourse analysis. Disponível em: <http://www.discourse-insociety.org/teun.html>. Acesso em: 24 nov. 2005.

(2005a). Discurso, conocimiento e ideologia. Reformulación de viejas cuestiones y propuesta de algunas soluciones nuevas. Disponível em: <http://www.discursos.org/Discurso,\%20conocimiento\%20e\%20ideologia.htm>. Acesso em: 24 nov. 2005.

(2005b). Discurso, Notícias e Ideologia. Estudos na Análise Crítica do Discurso. Tradução de Zara Pinto-Coelho. Porto: Campo das Letras.

(2007). Macro Contexts. In: LOTTGEN, U. D. S.; SÁNCHEZ, J. S. (Eds.). Discourse and International Relations. Lecture First International Conference on Discourse and Intercultural Relations, University of Murcia, September 2004. Bern: Lang, p.03-26.

261.

. (2008). Semántica del discurso e ideologia. Discurso \& Sociedad, v.02, n.01, p. 201- 
VAN DIJK, T. A. (2009). Critical Discourse Studies. A sociocognitive approach. In: WODAK, R.; MEYER, M. (Eds.). Methods of critical discourse analysis. London: Sage. p.62-85.

(2010). Discurso e poder. São Paulo: Contexto.

VAZ, A. C. (2003). O Governo Lula: uma nova política exterior?. Nueva Sociedad, Anuario Social y Político de América Latina y el Caribe, Flacso/Unesco, Caracas, n. 6, p. 1-16. Disponível em: <www.unb.br/irel/ibsa/docs/acv_nuevasociedad.pdf>. Acesso em 11 maio 2010.

VEREZA, S. C. (2007). Literalmente Falando: o Sentido Literal como Metáfora CognitivoPragmática. Tese de doutorado. São Paulo: Pontífica Universidade Católica de São Paulo.

(2010). Articulating the conceptual and the discursive dimensions of figurative language in argumentative texts. DELTA, v.26, número especial, p.701-718.

VIGEVANI, T.; CEPALUNI, G. (2007). A Política Externa de Lula da Silva: A Estratégia da Autonomia pela Diversificação. Contexto Internacional, Rio de Janeiro, v.29, n.2, p.273-335.

(2009). Brazilian Foreign Policy in Changing Times. The quest for autonomy from Sarney to Lula. United Kingdom: Lexington Books.

VIZENTINI, P. G. F. (1999). O Brasil e o Mundo: a política externa e suas faces. Ensaios FEE, Porto Alegre, v.20, n.1, p.134-154.

(2003). Brazil's Foreign Policy and South American Integration. Porto Alegre: Universidade Federal do Rio Grande do Sul, p.01-08. Disponível em: < www.ufrgs.br/nerint/folder/artigos/artigo0153.pdf>. Acesso em: 15 jan. 2013.

(2008). Relações Internacionais do Brasil. De Vargas a Lula. 3. ed. revista e ampliada. São Paulo: Editora Fundação Perseu Abramo. 


\section{ANEXOS}

\section{PRONUNCIAMENTOS DO EX-PRESIDENTE DA REPÚBLICA LUÍS INÁCIO LULA DA SILVA, CORRESPONDENTES À POLÍTICA EXTERNA DE SEU GOVERNO, INSERIDOS EM CD-ROM}

